\title{
Psychologische aspecten van het leven met de kunstnier : een onderzoek naar de belevingswereld van haemodialysepatienten
}

Citation for published version (APA):

Loos, J. C. (1981). Psychologische aspecten van het leven met de kunstnier : een onderzoek naar de belevingswereld van haemodialysepatienten. [Doctoral Thesis, Maastricht University]. Rijksuniversiteit Limburg. https://doi.org/10.26481/dis.19810220jl

Document status and date:

Published: 01/01/1981

DOI:

10.26481/dis.19810220jl

Document Version:

Publisher's PDF, also known as Version of record

Please check the document version of this publication:

- A submitted manuscript is the version of the article upon submission and before peer-review. There can be important differences between the submitted version and the official published version of record.

People interested in the research are advised to contact the author for the final version of the publication, or visit the DOI to the publisher's website.

- The final author version and the galley proof are versions of the publication after peer review.

- The final published version features the final layout of the paper including the volume, issue and page numbers.

Link to publication

\footnotetext{
General rights rights.

- You may freely distribute the URL identifying the publication in the public portal. please follow below link for the End User Agreement:

www.umlib.nl/taverne-license

Take down policy

If you believe that this document breaches copyright please contact us at:

repository@maastrichtuniversity.nl

providing details and we will investigate your claim.
}

Copyright and moral rights for the publications made accessible in the public portal are retained by the authors and/or other copyright owners and it is a condition of accessing publications that users recognise and abide by the legal requirements associated with these

- Users may download and print one copy of any publication from the public portal for the purpose of private study or research.

- You may not further distribute the material or use it for any profit-making activity or commercial gain

If the publication is distributed under the terms of Article 25fa of the Dutch Copyright Act, indicated by the "Taverne" license above, 
PSYCHOLOGISCHE ASPECTEN VAN HET LEVEN MET DE KUNSTNIER

- EEN ONDERZOEK NAAR DE BELEVINGSWERELD VAN HAEMODIALYSEPATIENTEN -

( WITH A SUMMARY IN ENGLISH).

\section{PROE.FSCHRIFT}

ter verkrijging van de graad van doctor in de geneeskunde aan de Rijksuniversiteit Limburg, op gezag van de Rector Magnificus

Dr. W.H.F.W. Wijnen, hoogleraar in de faculteit der geneeskunde, volgens besluit van het College van Dekanen in het openbaar te verdedigen op vrijdag 20 februari 1981, des namiddags om 16.00 uur precies, in de aula der universiteit.

door

JAN CORNELIUS LOOS

geboren te Arnhem 

Promotior

Referenten

Prof. Dr. J.J.C.B. Bremer

Prof. Dr. H. Philipsen

Prof. Dr. C. v.d. Meer

Prof. Dr. C.J. Menges

De uitgave van dit proefschrift werd mogelijk gemaakt mede dankzij financiële steun van de Nierstichting Nederland en de firma GAMBRO. 
Aan mijn moeder

en wijlen mijn vader

Aan Greetje, Erik Jan,

Dietrich en Hans Wicher 
INHOUD.

Pag.

1 Literatuuronderzoek

1.1 Inleiding 1

1.2 Theoretische concepties over de situatie van de kunstnierpatiënt

1.2.1 De situatie van de kunstnierpatiënt als marginaie 3 situatie

1.2.2 De situatie van de kunstnierpatiënt als grenssi- 6 tuatie

$2 \quad$ Probleemstelling

3 Vooronderzoek 13

3.1 Inteiding 13

3.2 Opzet wooronderzoek 16

3.3 Methode van onderzoek 18

3.4 Vertaling van de begrippen belevingsaspecten en 20

3.5 De hypothesen 21

3.6 Resujtaten ten aanzien van hypothese I en de 25 daaruit afgeleide voorspellingen

3.7 Resultaten van hypothese II en de daaruit afge- 36 leide voorspellingen

3.8. Discussie 40

3.8.1 Doorgangsdialysepatiënten. 40

3.8.2 Chronische diailysepatiënten> 50 jaar 40

3.8.3 Chronische dialysepatiënten < 50 jaar 4.1

3.8.4 Carcinoompatiénten (vergelijkingsgroep) 43

3.9 Conclusies 46

$4 \quad$ Onderzoek 49

4.1 Inleiding 49

4.2 Probleemstelling 52

4.3 Onderzoeksopzet 52

4.4. Methode wan onderzoek 56 
4.5. De vragenlijst 58

4.5.1. Onderzoeksvragen met betrekking tot de vragenlijst. 60

4.5.2. Resultaten en bespreking wan het vragenlijstonderzoek: 61 de kwantitatieve gegevens.

4.5.3. Resultaten van de statistische bewerkingen van het 71 vragen 1 ijstonderzoek.

4.5.4. Arbeidssituatie. 74

4.5.5. Bespreking der resultaten $\quad 79$

4.5.6. Gegevens over de arbeidssituatie.

4.6. Het onderzoek door middel van de uitsprakenlijst. 86

4.6.1. De hypothesen. 80

4.6.2. De factoranalyse. 88

4.6.3. Resultaten van de statistische bewerkingen van het 88 onderzoek inzake de uitsprakenlijst

4.6.4. Resultaten en bespreking van de variantieanalyse voor 92 de variabelen werken en dialyseduur.

4.6.5. Resultaten en bespreking van factoranalyse op de uit- 95 sprakenlijst.

4.7. Vergelijking van vooranderzoeks - en onderzoekresuitaten 104 met betrekking tot de uitsprakenlijst.

5. Het onderzoek van de semantische differentiaal (I) 106

5.1. Onderzoeksresultaten met betrekking tot de semantische 111 differentiaal

5.1.1. Overzicht en bespreking van de onderzoeksresultaten betreffende de begrippen/categorieën, instituten, personen en situaties.

5.1.2. Overzicht en bespreking van de onderzoeksresultaten met $\quad 124$ betrekking tot de begrippen afzonderijjk.

5.2. Voortgezet onderzoek met de semantische differentiaal (II) 132 en bespreking van resultaten.

5.2.1. Slotopmerkingen met betrekking tot de semantische differential.

5.3. Vergelijking van drie onderzoeksinstrumenten -de corre-

5.4. Conclusies. 
Pag.

6. Algemene discussie. 153

6.1. Inleiding. 153

6.2. Vergelijking van onderzoek en literatuurgegevens. 153

Nabeschouwing. $\quad 171$

Samenvatting. $\quad 172$

$\begin{array}{ll}\text { Summary. } & 176\end{array}$

Literatuur. $\quad 180$

Bijlagen. 195 
Woord vooraf.

uit promotie-onderzoek is voor mij een, zij het wat verlate, afsluiting van mijn universitaire studie.

Hooggeleerde wijngaarden, ik heb het altijd als een woorrecht beschouwd ền van uw leerlingen te zijn.

Dok uw bemoediging, in woord en geschrift jegens mij geult, heeft mij veel geholpen bij de tatstandkoming wan deze studie.

Hooggeleerde Drenth (Pieter), u hebt mijn, op fenomenologische leest geschoeide, belangstelling indertijd van cen stevige methodologische basis voorzien.

Met dankbarheid denk ik terug aan de gelegenheid die u mij gaf enkele jaren ëen van uw assistenten te zijn en onder uw inspirerende leiding te mogen werken.

Ik ben u daar zeer erkentelijk voor.

Hooggeleerde Bremer, het valt mij niet makkelijk in woorden mijn dank. wit te drukken die ik u verschuldigd ben.

op de weg naar een wetenschappelijke afsluting van mijn studie heb ik mij soms gevoeld "als het volk Israël, ronddolend in de woestijn", maar juist op die momenten hebt $u$ mij het zicht doen houden op het "beloofde land" van uw capaciteitsgroep.

Ik ben en blijf u dankbaar voor uw critische, zorgvuldige en inspirerende begeleiding bij dit onderzoek.

In deze dank will ik ook graag betrekken dr. Appels en dhr. van Houtem van de capaciteitsgroep medische psychologie die, andanks een overladen rekenprograma, toch kans zagen de statistische bewerkingen van dit onderzoek te verzorgen en mej. Emmy Lippertz die het manuscript een en andermaal heeft uitgetypt.

Hooggeleerde Philipsen, het heeft mij veel voldoening gegeven dat u na lezing van mijn eerste concept met nadruk hebt geadviseerd op de ingeslagen weg verder te gaan.

Met uw critische analyserende geest, met uw gekruide, soms ongezouten, opmerkingen hebt $u$ een belangrijke inbreng gehad bij de totstandkaming van dit proefschrift. 
Hooggeachte en zeergeleerde Hintzen. Deze studie werd vanuit de onder uw leiding staande kunstnierafdeling voorbereid en na uw - betreurd vertrek vol tooid.

Ik dank u voor de "ruimte" en het vertrouwen dat u mij gaf.

Ik voel mij met $u$ op een bijzandere wijze in samenwerking en wriendschap verbonden sinds $u$ in 1971 mijn medewerking hebt gevraagd voor de afdeling, aan welke ik mij gaarne heb verbonden.

Hooggeleerde Sporken, wij hebben elkaar ieder vanuit ons vakgebied veel gezegd en nog veel te zeggen.

Wij hebben, denk ik, elkaar herkend ook vanuit de belangstelling voor de wereld waarin kunstnierpatiënten leven.

In die wereld heb ik mij trachten in te leven, hetgeen mij niet altijd is gelukt.

Aan de kunstnierpatiënten uit Nederland, van wie velen mij met dit anderzoek hebben willen helpen, draag ik deze studie op, in de hoop daarmee een bijdrage te leveren voor meer begrip ten aanzien van de psychosociale problematiek, voortvloeiend uit de nierfunctievervangende behandeling. Lieve Greetje, veel dank voor je steun, toewijding en geduld in deze afgelopen jaren, wij zullen met elkaar en met de jongens weer samen kunnen optrekken. 
Inileiding

Toepassing van haemodialyse en niertransplantatie ter behandeling van ernstige en terminale irreversibele chronische nierinsufficientie kan worden beschouwd als een voorbeeld yan de spectaculaire vorderingen die de geneeskunde vanaf de jaren '50 heeft gekenmerkt.

Wie omziet doet dit "in verwondering" want nu blijkt mogelijk wat toen nog als science fiction werd beschouwd.

Wat zijn echter de psychologische implicaties van het hebben van een levensbedreigende aandoening en het onderhevig zijn aan behamdeling met de meest ingewikkelde apparatuur?

De voorliggende studie poogt daarop een antwoord te geven met betrekking tot het "Jeven met de kunstmier" a bij de z.g. doorgangsdialysepatiënten, degenen die voor een niertransplantatie in aanmerking komen en b de chronische dialysepatiënten, degenen die om uiteenlopende redenen niet meer voor een transplantatie in aanmerking komen.

Voor onderzoek met betrekking tot andere categorieën kunstnierpatienten kan wat ons land betreft verwezen worden naar onderzoek i.v.m de psychische aspecten van kinderdialyse vanuit het Withelminakinderziekenhuis Utrecht (Wolters e.a.), het door Schneeman en de Vries-de Regt verrichte evaluatieonderzoek - thuisdialyse-patiënten (1975) - en het door v.d. Born en v.d. Broek uitgebrachte rapport (vakgroep ontwikkelingspsychologie Nijnegen) over psychologische aspecten van nierfunctievervangende behandeling (1975), warin de ervaringen worden beschreven van o. a. prae-dialyse- en getransplanteerde patiènten.

Deze studie is ontstaan vanuit de ervaring die de onderzoeker opdeed binnen een multidisciplinair behandelingsteam van het St. -Annadal Ziekenhuis te Mastricht.

Tot deze ervaring behoorde het gegeven dat naast persoonlijkheids - en omgevingsvariabelen de wijze warop kunstnierpatiënten hun behandeling beleven ook gerelateerd is a an het al of niet transplantabel zijn.

Dit gegeven vormde het uitgangspunt voor de beschreven probleemstelling. Binnen deze vrij strakke onderzoeksbeschrijving komen de inhoudelijke kanten van de wijze warop kunstnierpatiënten hun behandeling ervaren weinig tot lhun recht.

Voor dit aspect zij verwezen naar het boek "Leven met de Kunstnier", J.C. Loos, 1980, dat als voorstudie van dit onderzoek kan worden aangemerkt. 
1. - Literatuuronderzoek -

1.1. Inteiding:

De relatieve benerktheid van de literatuur over de psychosociale aspecten van de kunstnierbehandeling in aanmerking genomen, is het omerkelijk hoe verschillend de levenssituatie van de kunstnierpatiënt wordt beoordeeld.

Deze diversiteit is met de volgende voorbeelden te in iustreren: Barker (1963) en Gutsch (1964), laten zich vrij optimistisch en positief uit over de instelling van hun patiënten t.a.v. hun situatie, met name wat betreft hun goede moreel, voortzetting van activiteiten en coöperatief gedrag. Anderen, zoals Combos (1964) en Kaplan de Nour (1968) accentueren de afhankelijkheidssituatie en vermelden negatieve psychische reacties als zich terugtrekken, angstverschijnselen, ontkenningsen vermijdingsgedrag, het negeren van dieetvoorschriften en sü̈cidale neigingen.

Sand e.a. (1966) vermelden redelijke aanpassingsresultaten, zij het dat zij deze toeschrijuem aan de screeningsprocedure die an de behandeling wooraf ging. Wright e.. (19f6) zijn van mening dat de kunstnierbehandeling gepard gat met verlieservaringen die als stressfactoren worden aangemerkt: verlies van lichaamsfuncties, verliès van contacten, van werk, van status en carrièremogelijkheden, verlies van toekomstperspectief.

Voorbeelden van een meer optimistische, mar ook relativerende visie vinden we bij Narton (1969): "Assuming the treatment to 
be dependable, the death for the kidmeypatient is as remote as impredictable as it is for the rest of us" (Norton 1969, pag. 721). "Behoudens dieet en vochtbeperkingen is het de kunstnierpatiënt mogelijk een vrijwel normaal leven te leiden en de rol in het gezin en in het werk te hervatten" (Roodvoets en Struyvenberg, 1970).

In thet verlengde hiervan stelt de Wardener (1966): "with all its linitations, life on intermittent dialysis can be pleasant and fruitfut" en ... "in spite of the restrictions .... most patients enjoy life and are at work" (pag. 106). Deze reeks van voorbeelden wit de literatur met uiteenlopende visies m.b.t. het dialysegebeuren is af te sluiten met de balans die R.A.J. Eady, arts en zelf (thuis) dialysepatiënt opmakt: "The patient who is dependent on maintenance dialysis cannot lead a normal life" (Rapaport, 1973, a second look at life, pag, 45).

Het is warschijnijk dat de hierboven a angehaalde verschillen in de beoordeling van de situatie van kunstnierpatiënten samenhangen met de discrepantie tussen objectiveerbare en niet objectiveerbare beoordelingscriteria. Als abjectiveerbare criteria kunnen die klinische en psychologische gegevens betreffende de patiënt worden aangemerkt, die via kwantificeerbare methoden worden vastgesteld.

Als niet objectiveerbaar criterium kan, afgezien van de "personal bias" die aan elk onderzoek inherent is, in eerste instantie worden gedacht aan de niet zelden wisselende wijze warop de patiënt zelf zijn/haar situatie beleeft. Men mag aannemen dat 
deze situatiebeleving sterk samenhangt met het verwachtingsbeeld dat iedere kunstmierpatiënt over zijn situatie heeft. Dit verwachtingsbeeld hangt warschijnlijk samen met zowel interne persoonlijkheidsvariabelen als externe factoren zoals dialysedur, kansen en mogelijkheden voor een transplamtatie, ontwikkeling van het $k$ linische beeld etc.

Meerdere onderzoekers hebben gewezen op de sterke discrepantie, juist bij kunstnierpatiënten, tussen deze objectiveerbare en niet objectiveerbare beoordelingscriteria. Zo werden Glasman en Siegel (1970) verrast door het verschil tussen psychologische onderzoekgegevens (vrijwell alle patiënten lagen rondom de gemiddelde norm) en de klinische indruk over deze patiënten, die aanzienlijk minder normal bleek.

Kaplan de Nour (1971) stelt dat de meningsvoming over kunstnierpatiënten vanuit een dialyseteam gedeeltelijk berust op objectief waarneembaar gedrag (feiten), maar ook beĩnvloed wordt door andere, meer subjectieve factoren, zoals wensen, verwachtingen en vooroordelen.

1.2. Theoretische concepties over de situatie van de kunstnierpatient.

1.2.1. De situatie van de kunstnierpatiënt als marginale situatie.

Het is de Amerikaanse sociologe Melanie Landsman geweest, die in een artikel (1975) de theoretische implicaties wan "the marginal man" (Stonequist, 1937, Child, 1943, Levin, 1948, Gordon, 1961. Newcombe, 1966) heeft toegepast op de situatie van kunstnierpatienten. 
De kernvraag van haar betoog: "Hoe ziet de kunstnierpatient zichzelf en hoe wordt hij/zij door de omgeving getaxeerd?", beantwoordt zij met: "Am I sick or am I well, a question that every patient with renal disease must struggle with periodically, if not constantly. They find themselves adrift somewhat between the world of the sick and the world of the well: they are in effect marginal men" (M. Landsman, 1975, pag. 268-269). De kunstnierpatient loopt het risico in een marginale situatie te geraken, zowel t.a.v. de wereld van de gezonden als van die van zieken. Deze wereld warover M. Landsman spreekt lijkt een "niemandsland". Kunstnierpatiënten dragen als het ware een dubbel paspoort 0.g.v. een dubbele nationalitejt. Ze hebben entree in de wereld van gezonde mensen (werkhervatting, de rol in het gezin), maar ook een voortdurende entree binnen het ziekenhuis, met dienovereenkomstig verwacht rolgedrag - de wereld van de patiënt - . Het verschil tussen deze beide werelden en hun onderlinge afstand beschreef Bremer in zijn studie over de ziekenhuispatiënt (J.J.C.B. Bremer, 1972). Aanvankelijk, vốr de aanvang van de kumstniembehandeling is degene die lijdende is aan een chronische nierinsufficiëntie patiënt. Men accepteert dat hij in deze situatie patient is. De verwarring begint wanneer na enige tijd van dialyseren sprake is van een medische min of meer gestabiliseerde situatie. De patiënt voelt zich dan doorgaans een stuk beter, maar is echter niet genezen.

De contradictie, typerend voor deze situatie, is dat hij langduric enkele malen per week in het ziekenhuis in de patiëntenrol kont, maar overigens in staat moet worden geacht een normaal Teven te leiden. "We send them out of the protected environment of the hospital into his own routine world with a handful of contradictory messages" (M. Landsman, p. 268, 1975). De "patient" mag blijuen werken maar moet we? een regeling treffen on in verband met spoelingstijden af wezig te kunnen zijn. 
Hij moet vooral niet gefixeerd raken in zijn patientenrol en op zijn ziek-zijn, mar dient zich wel strikt aan de voorschriften te confomeren, en er rekening mee te houden dat moeheid, apathie, lusteloosheid en verminderde sexwele potentie nomale bijuerschijnselen zijn van zijn aandoening en behandeling.

Ambivalente verwachtingen die de patient heeft ten opzichte van de behandelingsresultaten, een eventuele transplantatie en het ambivalente verwachtingspatroon van de omgeving leiden tot thijfel, verwarring en onzekerheid over eigen rol en status. Ben ik nuziek of gezond? Wat verwacht men nu eigenlijk van mij? Een voortdurend dilemma waar noch de patiënt noch de ongeving een duidelijk antwoord op geeft of warbij zoveel "slagen om de arm" worden gehouden dat het de marginale positie van de betrokkene slechts bevestigd. "It is this marginality between $i l n$ ness and health that is to great extent responsible for the manifestations of inner turmoil that become visible to staff members" (M.L. Landsman, 1975, p.269).

De afstand tussen de wereld van de zieke en die wan de gezonde houdt het risico in wan een kloof tussen beide. Binnen het ziekenthis is deze kloof materieel gemarkeerd door evenzovele deuren, gangen, portalen enz. (Bremer, 1972).

Het moet voor de kunstnierpatiënten een welhast onmogelijke opgave zijn de afstand tussen deze twee werelden, elk gekermerkt door een eigen belevingsklinat en vragend om een ander rolgedrag, te overbruggen. In dit opzicht kan deze kloof leiden tot een verstoorde commuicatie tussen de patiënt en de gezonde mensen in zijn omgeving. Een bron van commuicatiestoornissen vormt bijvoorbeeld het gedrag van hulpverleners, die het ziek zijn van de patiënt aanwaarden a 15 een "fait accompli" 
Mc. Kegney, Lange 1971, Fellner 1971, Loos 1978).

"Het zich voortdurend bevinden op het grensvlak van gezond zign en ziek zijn, zonder het een of ander te zijn, leidt tot rolgedrag gekenmerkt door onzekerheid, twijfel, ambivalentie en wrok tegenover de eigen persoon en/of de omgeving".

Pogingen om aan dit niemands land te ontkomen via afwijzingen, identificatie of ontkenning, lossen dit dilemma niet op mar bevestigem deze situatie (Loos, 1979).

1.2.2. De situatie van de kunstnierpatiënt als grenssituatie. Het begrip grenssituatie in relatie tot kunstnierpatiënten werd woor het eerst toegepast door Fel1ner in een reactie op een referat wan Mc. Kegney en Lange (1971). De term grenssituatie is afkomstig van Karl Jaspers; Jaspers spreekt over de grenssituatie als eem situatie warin de mens ten einde raad is, warin hij zich niet meer geborgen weet binnen de veiligheid van alles wat zeker is en houvast biedt.

In de grenssituatie bevindt de mens zich aan gene zijde van wat normal, vertrouwd, veilig en bekend is. In een dergelijke situatie verdwijnt het toekomstperspectief voor een mens en wordt hij bedreigd door de leegte (K. Jaspers, Allgemeine Psychopathologie, Berlin, 1948, p. 257, idem Philosophie, vol. 2, Berlin, 1932, pag. 201 e.v.). In navolging van $K$. Barth (1948) stelt de Nederlandse theoloog Jonker (1952) dat de mens tegenover de grenssituatie van het lijden drieërlei houdingen kan aannemen: 
- hij kan het bestrijden b.w. door toepassing van medische, sociale en politieke matregelen,

- hij kan het ontwijken en ontkennend reageren door te doen alsof grenssituaties niet bestaan,

- hij kan het verwerken d.w.z. het serieus nemen van de grenssituatie van lijden, schuld, ziekte en dood.

Bij auteurs als Tillich (1958), Alvarez (1975), v.d. Berg (1954) is de menselijke grenssituatie daar bereikt war de menselijke mogelijkheden eenvoudigweg ten einde zijn en de nenselijke existentie onder de absolute bedreiging is gesteld. De grenssituatie verhult zich in de macht van een bestaan dat het leven verwoest, het heden ontwricht en de toekomst op het spel zet (Metz, 1975).

ook binnen het ziekenhuis worden patiënten en diegenen die bij de behandeling betrokken zijn geconfronteerd met situaties die als grenssituaties kunnen worden getypeerd.

Voorbeelden hiervan zijn intensive-care afdelingen, afdelingen voor open hart chirurgie, coronair-care en haemodialyse-afdelingen.

Geinspireerd door Nahum en Mc. Kegney (1966) stelt Freyberger dat als gevolg wan de medisch technische mogelijkheden van deze tijd nieuwe "psycho-syndromen" als ziekte-eenheden ontstaan: 
andsttoestanden, gevoelens van hopeloosheid, katastrofereacties en depressies. In deze reactuepatronen kont naar voren hoezeer de stormachtige ontwikkeling in de moderne geneeskunde een 2 ware hypotheek kan leggen op het incasseringsvermogen van patiënten.

"Wahum setzt das Erleiden mussen der schweren Krankheit und das Erleben mussen der therapeutischen Proceduren einem traumatisierenden Extrems i tuation gleich, und neuerdings wird der Begriff "Extremsituation" auch zur Kennzeichnung der psychologischen Belastungem bei Hämodialysepatienten im Dawerprogramm verwendet (Freyberger 1968, pag. 28).

De literatuur betreffende de psychosociale aspecten van de behandelingssituatie warin dialysepatiënten verkeren, biedt de volgende aanknopingspunten wat betreft dit grenssituatiemodel, gekenmerkt door gevoelens van hulpeloosheid, hopeloosheid, bedreiging, wanhoóp en de ervaren communicatiek loof met de omgeving:

Mc. Kegney registreert bij veertien kunstnierpatiënten depressies, het opgeven van hoop, objectverlies, verlatenheid, hopeloosheid en insufficiëntiegevoelens.

Het opgeven van hoop en de wens de behandeling te staken blijkt veelal door de hulpverleners niet begrepen noch gewardeerd te worden. "The staff continued to operate on the impliciet assumptions that, as bad as these patients lifes were, living was still preferable to dying" (Mc. Kegney, 1971, pag. 271). 
Door het gesprek over niet acceptabele wensen te vermijden, wordt de communicatiekloof gehandhaafd.

"Men is te fragmentarisch bezig en dit - het gespecialiseerd bezig zijn wan medewerkers uit de meest uiteenlopende disciplines - verhindert het totale engagement", aldus fellner (1971). "De wanhoop van de patient wordt versterkt door het. onbegrif dat hij ervart voor zijn situatie. Deze grenssituatie te kunnen delen met de patiënt vergt continuïteit in de ervaring met deze patiënten".

Dok Beard (1969) accentueert in zijn studie het dilemma waarvoor de kunstnierpatiënt stat: de vrees voor een onvolwardig leven met de kunstnier en de vrees voor een vroegtijdige dood bij afwijzing van de kunstnierbehandeling. Het bleek voor de in zijn onderzoek betrokken patiënten onmoge lijk te communiceren over hun gevoelens van angst, teleurstelling en alleen zijn. "Fear of living the unsatisfactory life of the chronic $i 11$ and handicapped person under constant medical care seemed allmost as fntolerable as the fear of immanent death" (Beard, 1969, p. 380). Abram (1968) en Fox (1970) spreken over voortdurende stress. "The person who lives succesfully with hemodialysis lives in a state of suppressed inner turmoil from which there can never be an escape exept in death" (Fox, 1970, p. 416). Kessel (1969) ziet de situatie van de kunstnierpatiënt als een existentiële bedreiging. Abram, Moore en Westervelt (1971) constateerden bij kunstnierpatiënten wanhoop, depressies en suicidale gevoelens en neigingen.

Kaplan de Nour (1971) noemt als kenmerkend voor de kunstnier- 
patiënt de uitzichtsloosheid, de angst voor de dreigende dood of onzekere toekonst.

De beperkingen die inherent zijn aan deze behandeling, de mogelijkheden van complicaties, een niet zelden langzaam proces van fysieke en psychosociale invalidering vormen even zovele bedreigende factoren in het leven van kunstnierpatiënten. 


\section{Probleenstelling.}

Het is de vraag of men wel in algemene zin kan spreken over de kunstnierpatiënt of de situatie van kunstmierpatiënten.

Tot nu toe ontbreekt een op wetenschappelijke gegevens gebaseerde theorie warin onderscheiden "categorieën" kunstnierpatiënten worden gedifferentieerd.

Het voorliggende onderzoek is gericht op het verkrijgen van inzicht in de belevinnsaspecten van de kunstnierbehandeling. De veronderstelling die aan dit onderzoek ten grondslag ligt is dat deze belevingsaspecten verband houden met de specifieke aard van de behandelsituatie. Op grond vam verschillen in behandelingssituatie zijn drie "categorieën" kunstnierpatiënten te onderscheiden:

A. doorgangsdialysepatiënten, deze patiënten zijn transplantabel en als zodanig geregistreerd bij Eurotransplant. Zij dialyseren in afwachting van een niertransplantatie,

B. de chronische dialysepatiënten, chronisch in de zin van blijvend, zonder transplantatieperspectief vanwege hun Teeftijd (>50 jaar).

c. kunstnierpatiënten die na eeen of meer mislukte transplantaties opnieuw op de kunstnier zijin aangewezen of om andeze redenen dan de leeftijd niet meer transplantabel zijn. Deze aroep kan worden omschreven alls de chronische jongere leeftijusgroep ( $<50$ jaar), zonder transplantatieperspectief - chronisch in de zim van niet (meer) transplantabel - 
De problemstelling voor het onderzoek is gecentreerd rond de volgende twee vragen:

I. Is het mogelijk de situatie van de kunstnierpatiënt te omschrijwen aan de hand van de op deze drie categorieën kunstnierpatiënten van toepassing zijnde belevingsaspecten?

II. Is het mogelijk de veronderstellingen rond het begrip grenssituatie, toegepast op de situatie van kunstnierpatienten, te beschrijven aan de hand van onderzoekgegevens?

Aan het begrip "grenssituatie" met betrekking tot kunstnierpatiënten zullen de volgende kenmerken worden verondersteld: gevoelens van hopeloosheid, isolement, hulpeloosheid, wanhoop, bedreiging, angst voor de toekomst en angst voor de dood. Deze verondersteliingen betreffende de kenmerken van het concept grenssituatie, worden in dit anderzoek getoetst bij bovengenoemde drie categarieën kunstnierpatiënten.

Het onderzoek naar de voor de situatie van kunstnierpatiënten kenmerkende belevingsaspecten, inclusief die welke passen binnen de gegeven omschrijuingen van de grenssituatie, werd in twee fasen verricht.

In de volgende paragraaf wordt gerapporteerd over de eerste onderzoeksfase, het vooronderzoek. 


\section{Het vooronderzoek.}

\subsection{Inleiding.}

Bij de opzet van dit vooronderzoek werd gebruik gemakt van de methode die Pritchard koos woor zijn factoranalytisch onderzoek naar "dimensies van ziekte" (Pritchard, 1974).

Hij makte gebruik van door patienten gedane uitspraken die hij selecteerde op zeven componenten of factoren. Verwolgens construeerde hij een "response to illness scalle" waarvoor hij vijftig uitspraken gebruikte die betrekking hadden op genoemde factoren. Conform Pritchard's opzet werd bij dit onderzoek gebruik gemaakt van door (kunstnier)patiënten gedane uitspraken, en wel als volgt:

Uit de bestaande literatuur werden die artikelen geselecteerd warin interviewgegevens, gespreksverslagen "case histories" en "case reports" werden vermeld. Deze selectie leverde de volgende publicaties op, warbij de tussen ( ) geplaatste getallen betrekking hebben op het aantal patiënten waaraan per artikel uitspraken werder ontleend. Abram, 1968 (vier), Beard, 1969 (veertien), Eisendrath, 1969 (elf), Cramond e.a., 1968 (twee), Salisbury, z.j. (een), Menzies, 1968 (zeven), Villard, 1968 (vijf), Wish e.a., 1966 (zes), Dansak, 1972 (twee), Landsman, 1975 (een), Levy e.a., 1975 (een), Abram, 1971 (vier), Abram, 1970 (vijf), Kaplan de Nour, 1970 (twee), Mc. Kegney e.a., 1971 (vier). Uit deze vijftien artikelen betreffende 69 patiënten werden in eerste instantie 278 uitspraken genoteerd. 
Somige uitspraken kwamen daarin in hoge frequentie voor.

b.v. angst en afhankelijkheid van de kunstnier en angst voor de dood, terwijl anderen slechts weinig of incidenteel werden vermeld.

Door die uitspraken die slechts zeer incidenteel werden vermeld uit te sluiten, antstond een lijst van zevenenvijftig items. Deze - vertaalde - 1ijst met uitspraken, waarvan in de aangegeven literatuur de minimale frequentie 10 en de maximale frequentie 26 was, is als bijlage IV opgenomen. Op "face-value" zijn de witspraken die dicht bij elkar Tiggen samengebracht tot eén cluster, b.v. "je toekomst als hopeloos ervaren" en "je warthopig voelen door alles wat je hebt verloren", zijn te rangschikken onder de cluster "wanhoop en hope loosheid".

Ditzelfde geldt voor uitspraken als "steeds angstgevoelens hebben bij aan- of afsluiten" of "angst voor de kunstnier hebben", te rangschikken onder cluster "angst voor de kunstnier". Aldus werden de volgende clusters gevormd: Anqst woor de apparatuur (cluster 1). Positieve mening ten opzichte van behandeling, personeel en ziekenhwis (cluster 2 ).

Weerstand ten opzichte van de behandeling (cluster 3). Steun van de partner (cluster 4 ). Sociaal isolement (cluster 5). Minderwaardigheidsgevoel (cluster 6 ). Verdringen, ontkennen, verzet tegen de dood (algemeen: defensieve mechanismen) (cluster 7 ). 
Angst roor de dood (cluster 8).

Aanvaarden van de dood (cluster 9).

Hoop, vastklampen aan medische mogelijkheden (cluster 10).

Continuering van de behandeling (cluster 11).

Suicidale gedachten of neigingen (cluster 12).

Wamhoop, hopeloosheid (cluster 13).

Deze door kunstniernatiënten zelf gedane witspraken vormen een belangrijk deel van de psychosociale problematiek die met de kunstnierbehandeling samenhangt.

Bepaalde clusters imponeren als de meer positieve belevingsaspecten zoals: een positieve attitude ten opzichte van de behandeling en ziekenhuis (cluster 2), steun van de partner (cluster 4), aanvaarding van de dood (cluster 9), hoop (cluster 10), continuering van de behandeling (cluster 11), terwijl andere clusters een negatieve warde lijken te hebben als belevingsaspecten. In verschillende van deze clusters zijn "grenssituatieaspecten", zoals getypeerd door K. Jasners (p.6), Mc. Kegney (p.6), Freyberger $(p .8)$, en Loos ( $p .7)$, herkenbaar bijvoorbeeld:

- sociaal isolement (cluster 5),

- minderwaardigheidsgevoelens (cluster 6),

- angst voor de dood (cluster 8),

- suicidale neigingen of gedachten (cluster 12),

- wanhoop, hopeloosheid (cluster 13). 


\subsection{Opzet vooronderzoek.}

De omstandigheden waronder de betreffende negenenzestig patiënten hun uitspraken deden, waren dermate divergent, dat door middel van het semi-gestructureerde interview eerst werd nagegaan in hoeverre deze uitspraken en de daaruit gevornde clusters ook van toepassing waren op een steekproef van Nederlandse kunstnierpatiënten.

Om de betrouwbaarheid en validiteit van de gebruikte methode - het semi-gestructureerde interview - te kunnen testen, tevens om de bereidheid te peilen bij kunstnierpatiënten in te gaan op onderzoeksvragen met een hoge delicaatheidsgraad, werd besloten aan het eigenlijke onderzoek een vaoronderzoek vooraf te laten gaan met een proefgroep van dertig kunstnierpatiënten (kunstnierafdeling ziekenhüis St. Annadal te Maastricht). In de semi-gestructureerde interviews kwamen steeds de volgende vragen ter sprake:

- Kunt U zich nog herinneren wat Uw gevoelens waren in de periode voorafgaande aan de aansluiting op de kunstnier?

- Hoe hebt $U$ de eerste maanden de behandeling ondergaan?

- In hoeverre heeft de kunstnierbehandeling Uw leven veranderd met betrekking op het gezin, het huwelijksleven, het werk en de sociale omstandigheden?

- Hoe staat $\cup$ nu tegenover deze behandeling?

- Hoe staat U tegenover een eventuele transplantatie?

- Wat zou U ervan vinden wanneer $U$ niet zou kunnen worden getransplanteerd? 
- Hebt U zich toen UW toestand ernstig was wel eens gerealiseerd dat $U$ mogelijk zou kunnen sterwen?

- Bent U door UW ziekte meer vertrouwd geraakt met de gedachte van de dood?

- Stelt U er prijs op, dat wanneer Uw toestand zo zou verergeren dat dialyseren niet meer mogelijk is, er vanuit de afdeling bepalde matregelen worden genomen of dat er met U over de ernst van de situatie zou worden gesproken?

Samenstelling van de onderzoeksgroep:

De onderzoeksgroep omvat een proefgroep van dertig kunstnierpatiënten en een vergelijkingsgroep van tien carcinoompatiënten. Deze onderzoeksaroep werd samengesteld uit de volgende subgroepen:

1. Groep $A$, doorgangsdialysepatiënten met een minimale dialyseduur van ëén jaar $(n=10)$.

2. Groep B, chrónische dialysepatiënten, ook weer met een minimale dialyseduur van ển jaar $(n=10)$, leeftijd $>50 \mathrm{jr}$.

3. Groep $C$, patiënten die om andere dan de leeftijdsredenen niet meer voor een transplantatie in aanmerking komen $(n=10)$. Dok voor deze groep geldt een minimale dialyseduur van eén jaar. Juist deze groep vormde het uitgangspunt voor het omschreven begrip "grenssituatie".

4. Groep $D(n=10)$, de vergelijkingsgroep bestaande uit carcinoompatienten die voor een bestralingstherapie enkele malen per week naar het ziekenhuis komen, dan wel daarvoor in het ziekenhuis zijn opgenomen. Aangenomen werd dat de situatie warin zij verkeren de nadige overeenkomst ver- 
toont wat betreft levensbedreiging en aangewezen zijn op een bepalde behandelüng in het ziekenhuis gedurende enkele malen per week.

De groepen zijn, met uitzondering van groep 2 (oudere leeftijdsgroep), vergelijkbaar inzake ieeftijd, burgerijike status en opleiding. Een evenwichtige en vergelijkbare verdeling van het aantal mannelijke en vrouwelijke patiënten binnen elke groep was niet mogelijk. (zie bijlage I). Voor alle groepen dienden de eerder genoemde vragen als uitgangspunten voor een semi-gestructureerd interview.

\section{3. Methode van onderzoek.}

Voor het verkrijgen van de voor dit onderzoek benodigde gegevens werd gebruik gemákt van de interviewmethode. Deze interviews werden gescoord op basis van inhoudsanalyse, volgens het principe van de meervoudige onafhanketijke beoordeling.

Deze methodische inhoudsanalyse is door Cartwright D.P. in zijn "Analysis of qualitative material" witvoerig beschreven (1966) als een onderzoekstechmiek voor objectieve systematische en kwantificeerbare beschrijuing van manifeste communicatie-inhoud.

In ons onderzoek werd gebruik gemaakt van drie beoordelaars*

* met dank aan de collegae Drs. H. Houben, Drs. J. van Zundert, Drs. H. Smeets. 
(k) inisch psychologen) die volgems deze methode onafhankelijk van elkaar de mamifeste inhoudselementen scoorden, voorzover deze van toepassing waren op de eerder genoemde dertien clusters. Als handleiding diende de lijst met uitspraken van kunstnierpatiënten (bijlage II).

De scoring heeft betrekking op: klassificatie-eenheden, d.w.z. specifieke onderdelen of segmenten van communicatieinhoud, welke typerend zijn voor een cluster. De voor scoring in aanmerking komende inhoudselementen werden gescoord op een puntsschaal : $0=$ niet van toepassing 1 = wel van toepassing

De interviews van veertig patiënten vonden plaats ïn de periode April-September 1975 door de onderzoeker. 


\subsection{Vertaling van de begrippen belevingsaspecten en grenssituatie in relatie tot hypothésem.}

De op "face value" gerangschikte clusters van uitspraken van kunstnierpatiënten zijn te beschouwen als het conceptue le model van belevingsaspecten.

Uitgaande van de veronderstelling dat deze belevingsaspecten verband houden met de specifieke aard der behandelsituatie werd onderscheid gemaakt tussen drie categorieën kunstmierpatiënten.

De vertaling van deze eerste veronderstelling in hypothesen dient derhalve in te houden dat de groepen $A, B$ en $C$ ten opzichte van elkaar zullen verschillen t.a.v. die clusters die specifiek geacht kunnen worden voor de afzonderlijke groepen. Hier vallen buiten die in clusters amschreven belevingsaspecten, warvan mag worden verondersteld dat ze 105 staan van de verschillen in behandelsituatie, ml.: angst voor de apparatuur (1), waardering voor de behandeling (2), steun van de partner (4) en continueren van de behandeling (11). De tweede veronderstelling betreft het conceptuele model van de grenssituatie, een situatie gekenmerkt door gevoelens van hopeloosheid, isolement, hulpeloosheid, wanhoop, bedreiging, angst voor de toekomst en angst voor de dood. Verondersteld is dat dit conceptuele model van de grenssituatie het meest van toepassing is op groep $c$ : patiënten die aanvahkelijk transplantabel, in een later stadium na éen of meer mislukte transplantaties opnieuw op de kunstnier zijn aangewezen, of on andere medische redenen niet meer transplantabel zijn. 
3.5. De hypothesen:

3.5.1. De drie onderscheiden groepen kunstnierpatiënten, aangeduid met groep $A$, groep $B$ en groep $C$, zullen ten opzichte van elkaar aantoonbaar verschillen t.o.v. het totaal der clusters-hypothese IVanuit deze hypothese I zijn de volgende voorspellingen af te leiden.

\subsubsection{Er bestaan aantoonbare verschillen} tussen de groepen $A, B$ en $C$ met betrekking tot de cluster weerstand tegen de behandeling (cluster 3$)$, in wie betekenis dat deze weerstand in groep $C$ groter is dan in groep $B$, en in groep $B$ groter dan in groep $A .(C>B>A)$. 3.5.1.2. Er bestaan aantoonbare verschillen tussen de groepen $A, B$ en $C$ met betrekking tot de cluster verdringen/ontkennen (afweermechan ismen, cluster 7), in die betekenis dat de mate van verdringing en ontkenning in groep A groter is dan groep $C$, en in groep $C$ groter dan in groep $B$. $(A>C>B)$.

3.5.1.3. Er bestaan aantoonbare verschillen tussen de groepen $A, B$ en $C$ met betrekking tot de cluster aanvaarden van de dood (cluster 9), in die betekenis dat de mate van aanvaarden van de dood in groep $B$ groter is dan in groep $C$, en in groep $C$ groter is dan in groep $A .(B>C>A)$. 3.5.1.4. Er bestaan aantoonbare verschillen tussen de groepen $A, B$ en $C$ met betrekking tot de 
cluster hoop en vastklampen aan medische mogelijkheden, in die betekenis dat het uiting geven aan deze hoop en het zich vastklampen aan medische mogelijkheden in grotere mate aanwezig is bij groep C t.a.v. groep A, en bij groep $A$ in gratere mate aanwezig is t.o.v. groep B. (C>A>B).

T.a.v. het conceptuele model van de grenssituatie mag worden verondersteld dat patiënten behorend tot groep $C$ de hoogste scores behalen op belevingsaspecten die samenhang vertonen met het omschreven grenssituatiemode1, $n 1$. "saciaal isolement" (5), "minderwaardigheidsgevoelens" (6), "angst voor de dood" (8), "suīcidale gedachten en neigingen" (12) en "wanhoop en hopeloosheid" (13).

3.5.2. Wat betreft het total van de $z \mathrm{gn}$. grenssituatieclusters verschilt groep $C$ van de groepen $A$ en $B$ en wel in die zin dat patiënten behorend tot groep $C$ de hoogste scores behalen op deze grenssituatieclustes - hypothese II - .

Wit deze hypothese II zijn de volgende voorspellingen af te leiden met betrekking tot de volgende clusters:

3.5.2.1. Er is een aantoonbaar verschil in de beleving van social isolement tussen patiënten die na ëen of meer mislukte transplantaties weer op de kunstnier zijn aangesloten en patiënten die wel transplantabel zijn (doorgangsdialysepatiënten), in die betekenis dat de scores van groep 
C betreffende cluster 5) dan die van groep $A$. 3.5.2.2. Er is een aantoonbaar verschil in de beleving van isolement tussen patienten die na één of meer mislukte transplantaties weer op de kunstnier zijn aangesloten, en chronische kunstnierpatiënten $>50$ jaar, in die betekenis dat de scores van groep $c$ betreffende cluster 5) dan die van groep $B$.

3.5.2.3. Er is een aantoonbaar verschil in de beleving t.a.v. angst voor de dood tussen patiënten die na êen of meer mislukte tranplantaties weer op de kunstnier zijn aangesloten, en patiënten die wel transplantabel zijn (doorgangsdialysepatiënten), in die betekenis dat de scores van groep $\mathrm{C}$ betreffende cluster $8>$ dan die van groep $A$.

3.5.2.4. Er is een aantoonbaar verschil in de beleving van gevoelens van wanhoop en hopeloosheid tussen patiënten die na één of meer mislukte transplantaties weer op de kunstnier zijin aangesloten, en chronische kunstnierpatiënten (boven de 50 jaar), in die betekenis dat de scores van groep $C$ betreffende cluster $8>$ dan die van groep $B$.

3.5.2.5. Er is een aantoombaar verschil in de beleving van gevoelens van wanhoop en hopeloosheid tussen patiënten die na ển of meer mislukte transpiantaties weer op de kunstnier zijn aangesloten en patiënten die wel transplantabel zijn, in die 
betekenis dat de scores van groep C betreffende cluster $13>$ dan die van groep $A$.

3.5.2.6. Er is een aantoonbaar verschil in de beleving van gevoelens van wanhoop en hopeloosheid tussen patiënten die na één of meer mislukte transplantaties weer op de kunstnier zijn aangesloten, en chronische kunstnierpatiënten, in die betekenis dat de scores van groep C betreffende cluster $13>$ dan die van groep $B$. 3.5.2.7. Er is een aantoonbaar verschil in het hebben van suïcidale gedachten en/of neigingen tussen patiënten met en zonder transplantatjeperspectief, in die betekenis dat de scores van groep $B$ betreffende cluster 12) dan die van groep $A$. 3.5.2.8. Er is een aantoonbaar verschil in het hebben van suĩcidale gedachten en/of suĩcidale neigingen tussen patiënten met en zonder transplantatieperspectief, in die betekenis dat de scores van groep $C$ betreffende cluster $12>$ dan die van groep A.

3.5.2.9. Er is een aantoonbaar verschil in het hebben van minderwaardigheidsgevoelens tussen patiënten met en zonder transplantatieperspectief, in die betekenis dat de scores van groep $B$ en $C$ betreffende cluster 6 $>$ dan die van groep $A$. 
3.6. Resultaten t.a.v. hypothese I en de daaruit afgeleide voorspellingen, $3.5 .1 .1 . \mathrm{t} / \mathrm{m} 3.5 .1 .4$.

De onderzoeksresultaten zijn vastgelegd in de volgende tabellen:

Tabel 1 geeft een overzicht van de percentages van de dertien clusters voor elke groep afzonderlijk.

Tabel 2 vermeldt de percentages voor die clusters van toepassing op het conceptuele model van de grenssituatie.

Tabel 3 geeft een overzicht van de op manifeste inhoudselementen gescoorde clusters, warvan de getallen de gemiddelde scores weergeven van drie beoordelaars.

Tabel 4 geeft weer de interbetrouwbarheidscoëfficiënten van drie onafhankelijke beoordelaars.

De tabellen 5 en 6 geven een overzicht van de met de $x^{2}$-toets berekende verschillen voor de groepen $A, B$ en $C$ en de vergelijkingsgroep D (carcinoompatiënten).

Tabei 5 geeft de $x^{2}$-scores weer van alle clusters, tabe 6 geeft de $x^{2}$-scores weer van de grenssituatieclusters.

In tabel 7 en figuren $1 \mathrm{t} / \mathrm{m} 4$ wordt een overzicht gegeven van de verschillen in scores voor de drie groepen kunstnierpatiënten met betrekking tot het aantal clusters, in grafieken. 


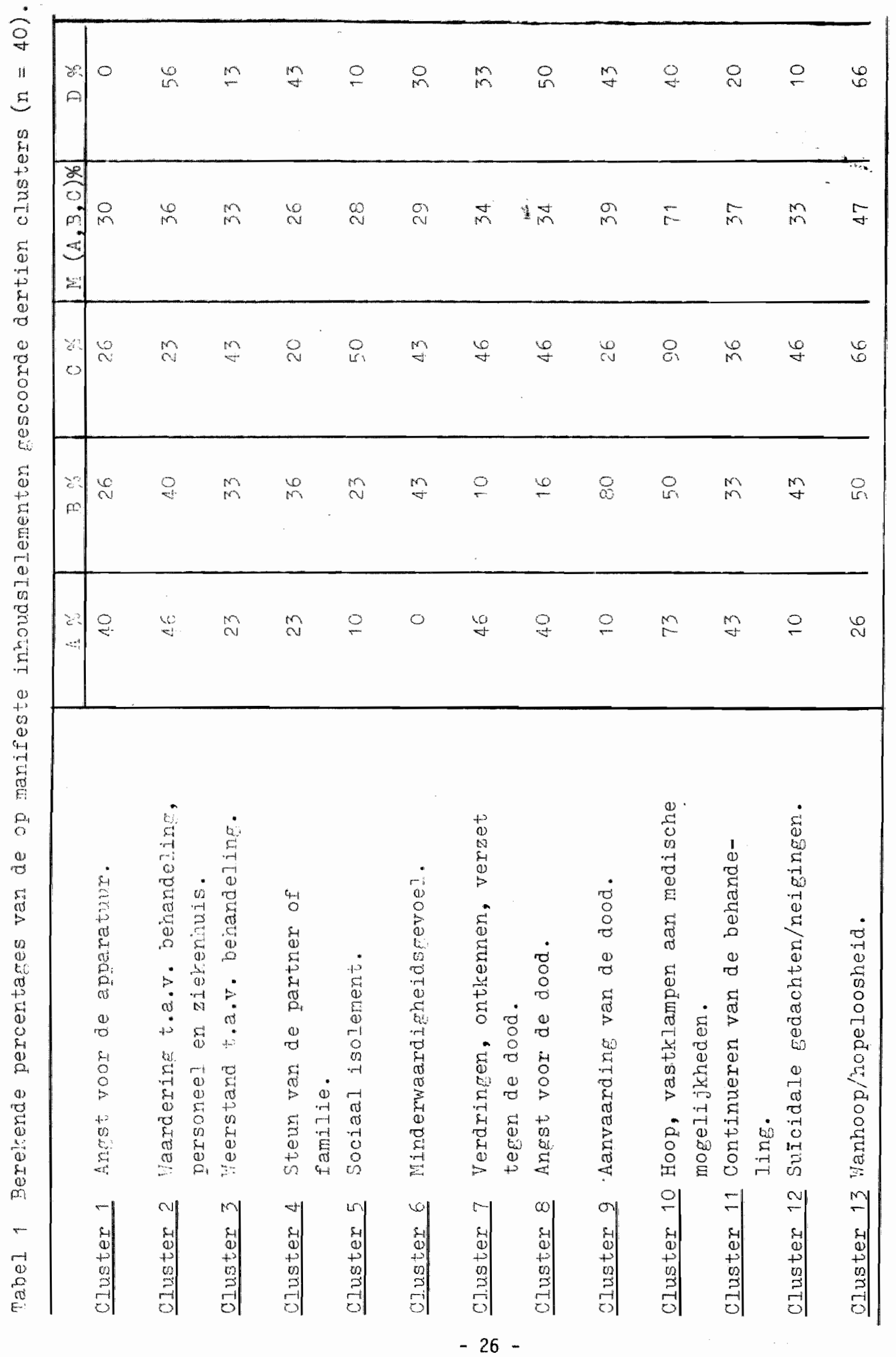




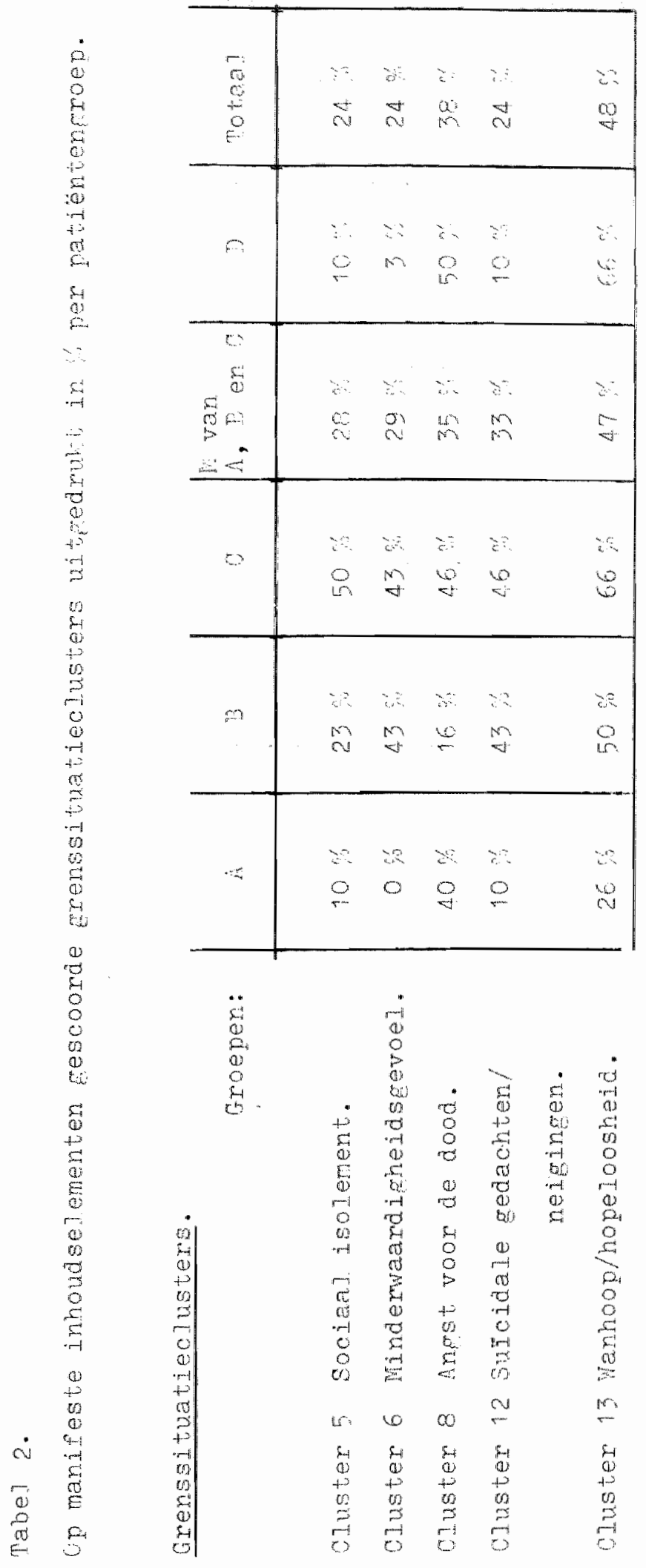


Tabel 4.

Interbeoordelaars betrowbaameidscoufficienten op basis van inhoudselementen.

Beoordelaars: I, II en III

Groepen : A, B, C en D.

clusters : 13 .

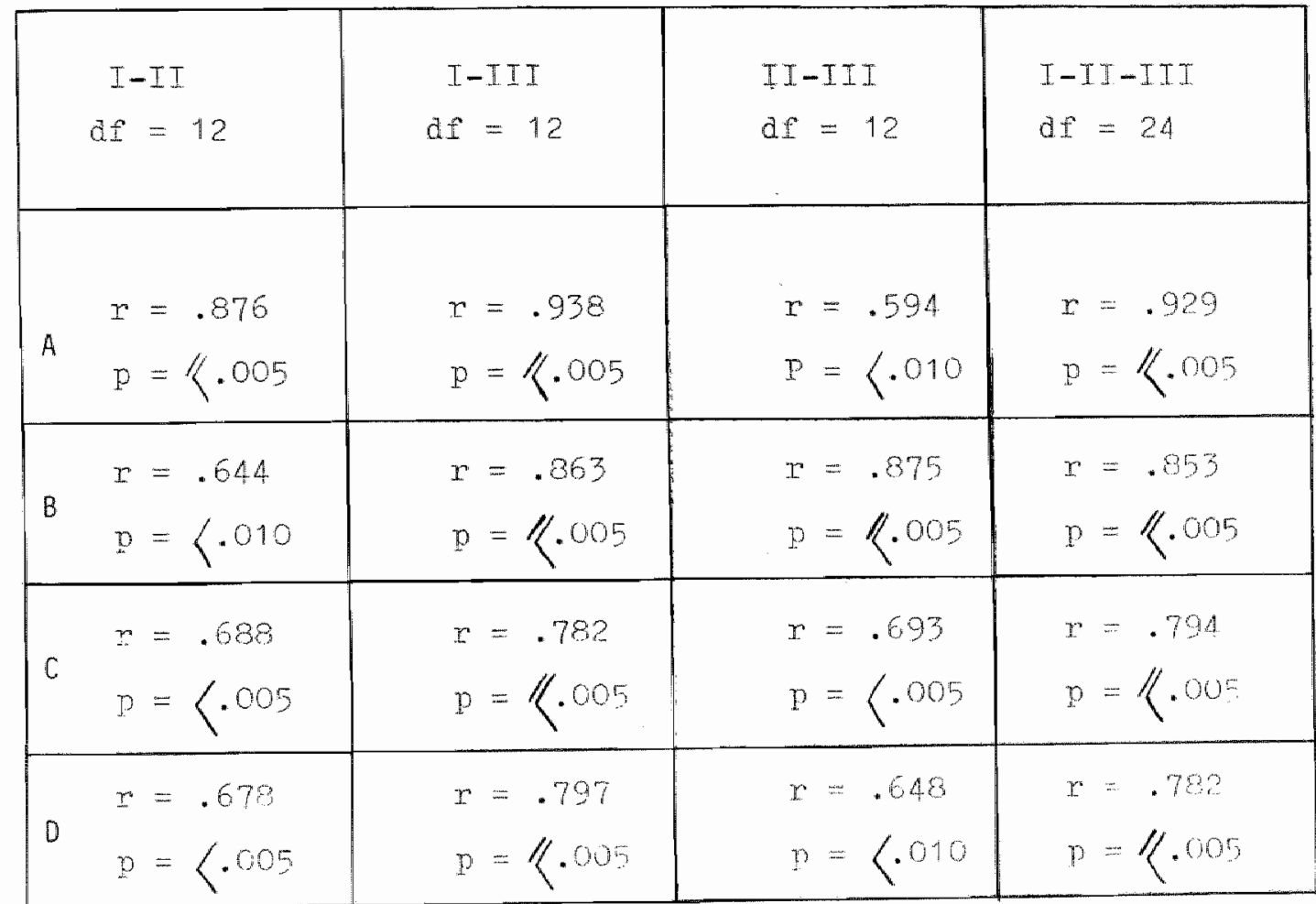

Hiner toets

wearidir $P=\mathbb{P}=01$ 
Tabel 5. Berekende verschillen $\left(x^{2}\right.$-toets $)$ tussen de groepen $A, B, C$ en $D$ m.b.t. het total der clusters (hypothese I).

\begin{tabular}{c|c|c|c|}
\hline \multicolumn{2}{|c|}{$A$} & \multicolumn{1}{c|}{$B$} & \\
\hline$B$ & 34.4 & & \\
\hline & $P<.01^{*}$ & & \\
\hline$C$ & 19.9 & 14.9 & \\
\hline & $P<.10$ & $P<.40$ & \\
\hline$D$ & 25.4 & 26.8 & 24.2 \\
\hline
\end{tabular}

Tabe 6. Berekende verschillen ( $x^{2}$-toets) tussen de groepen $A, B, C$ en $D$ m.b.t. het total der grenssituatieclusters $5,6,8,12$ en 13 (hypothese II).

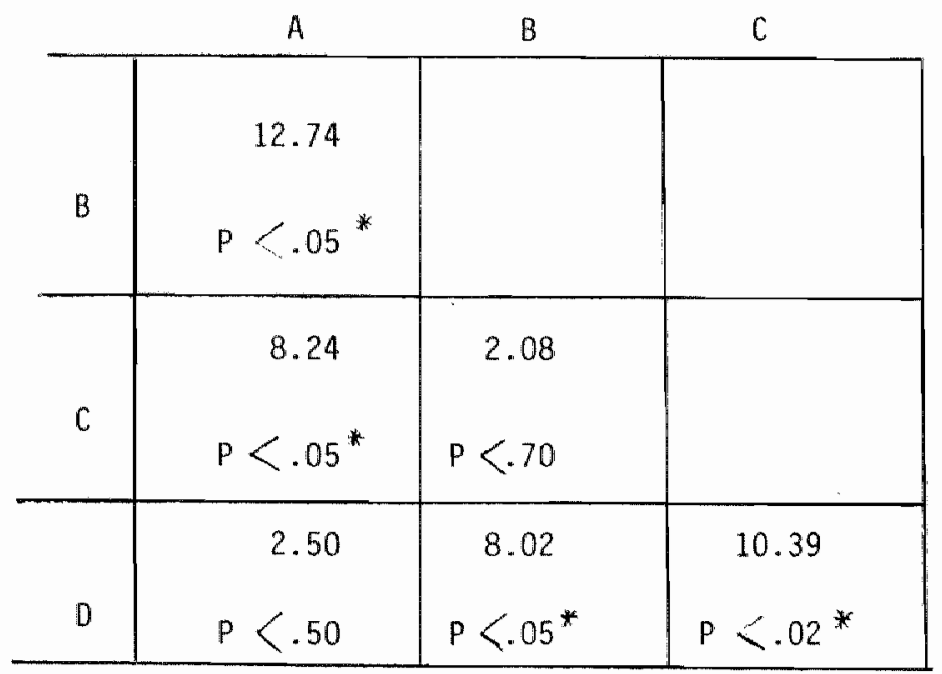




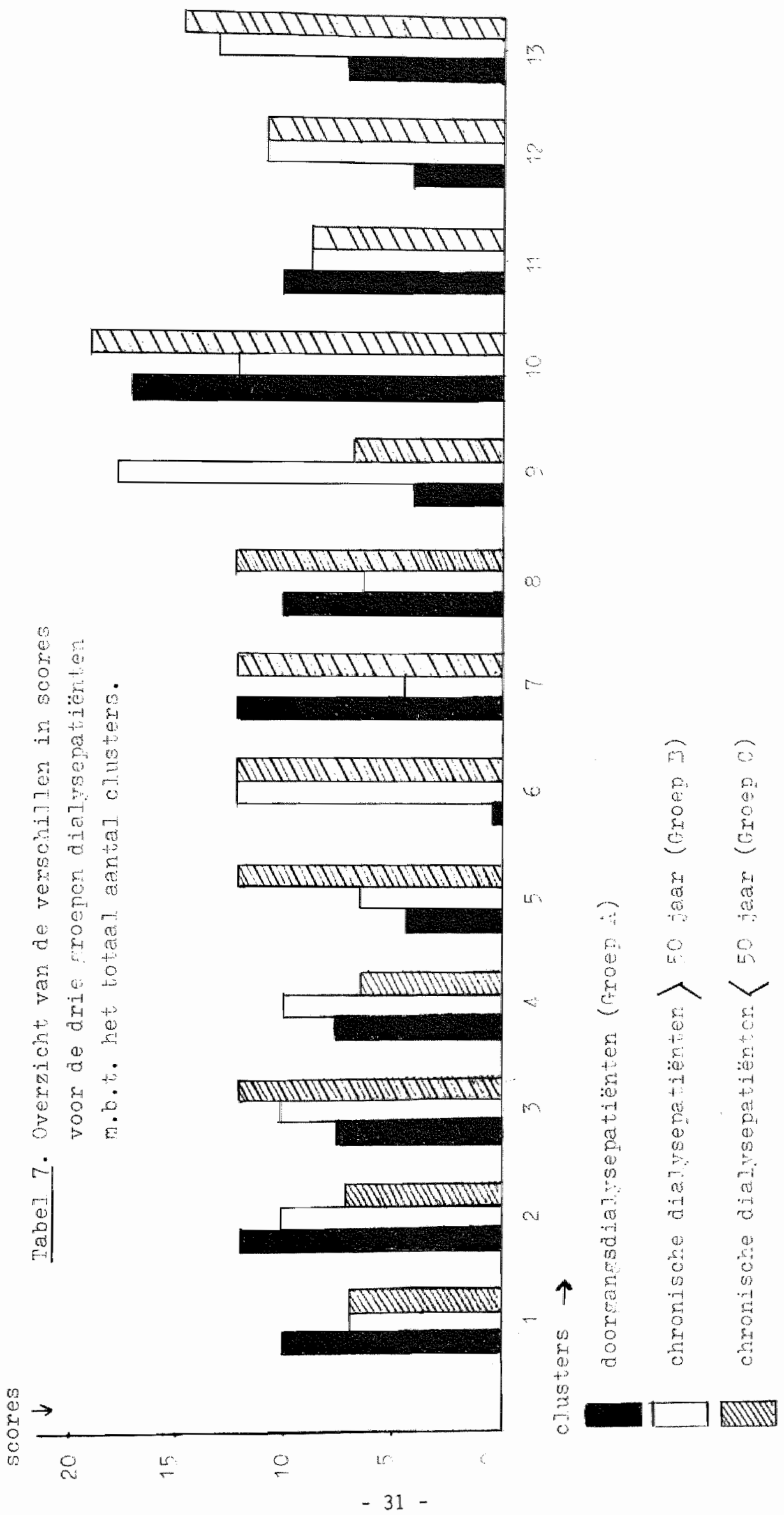


Figuur 1. Groep A: doorgangsdialysepatiënten

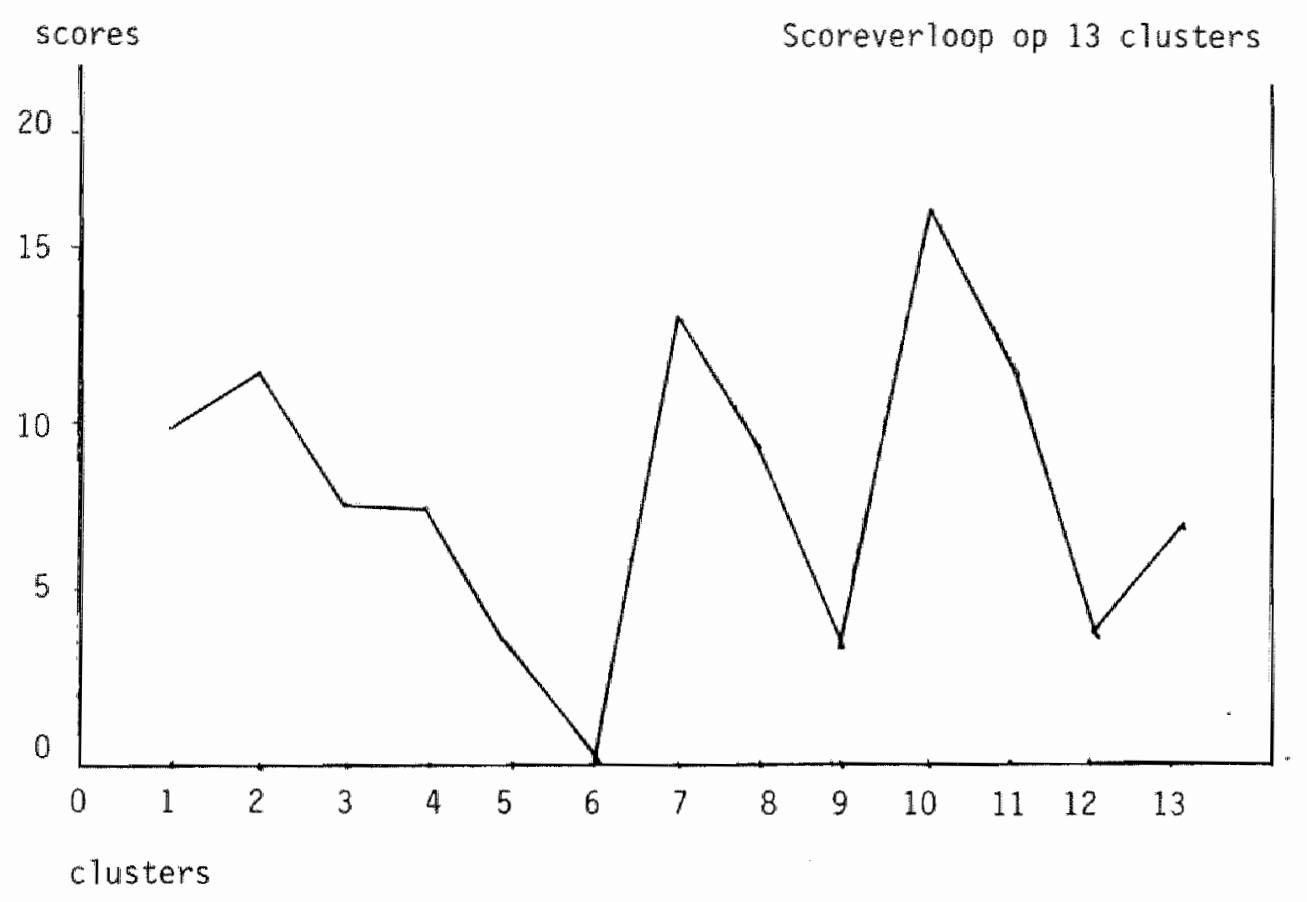

Figuur 2. Groep B chronische dialysepatiënten $>50 \mathrm{jr}$

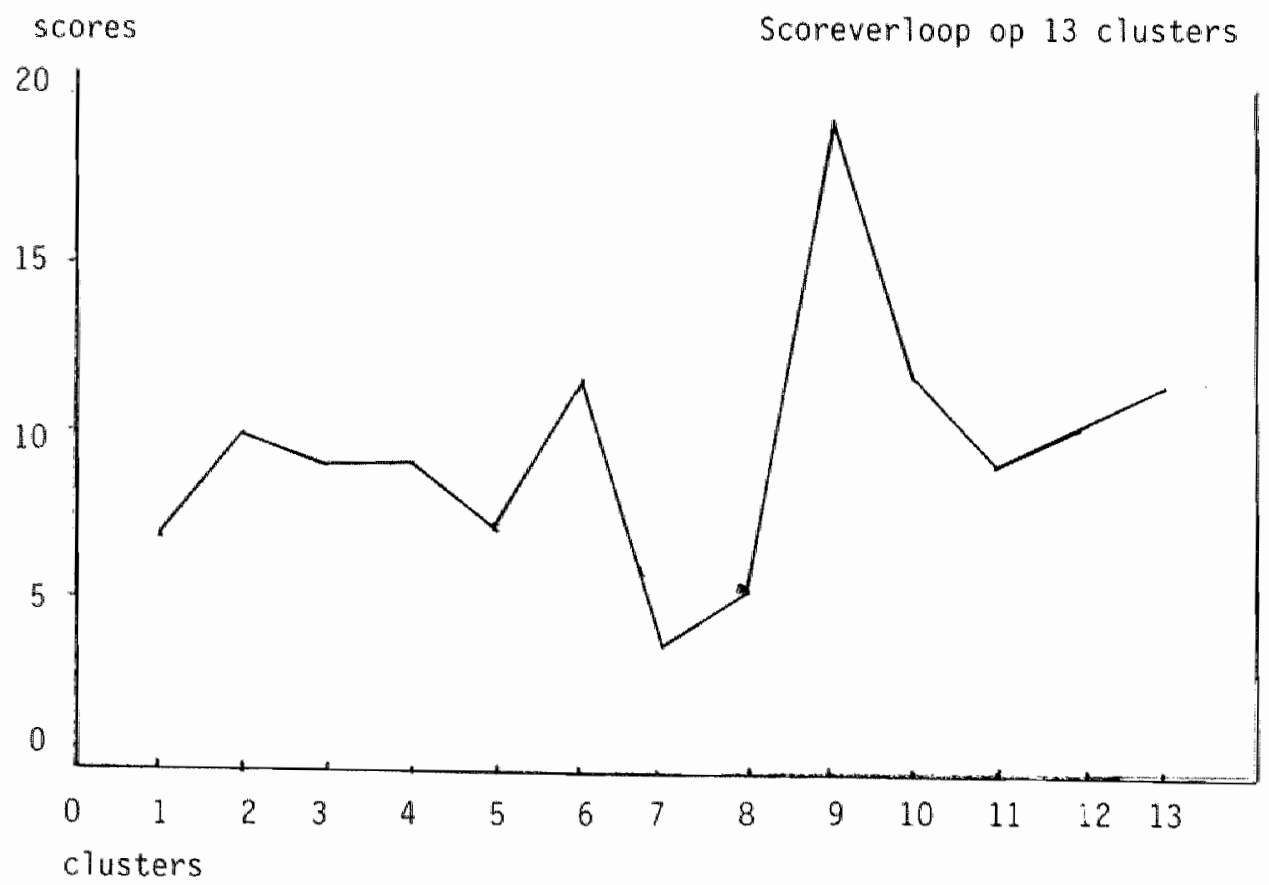


Figuur 3. Groep C chronische dialysepatiënten $\angle 50$ jaar

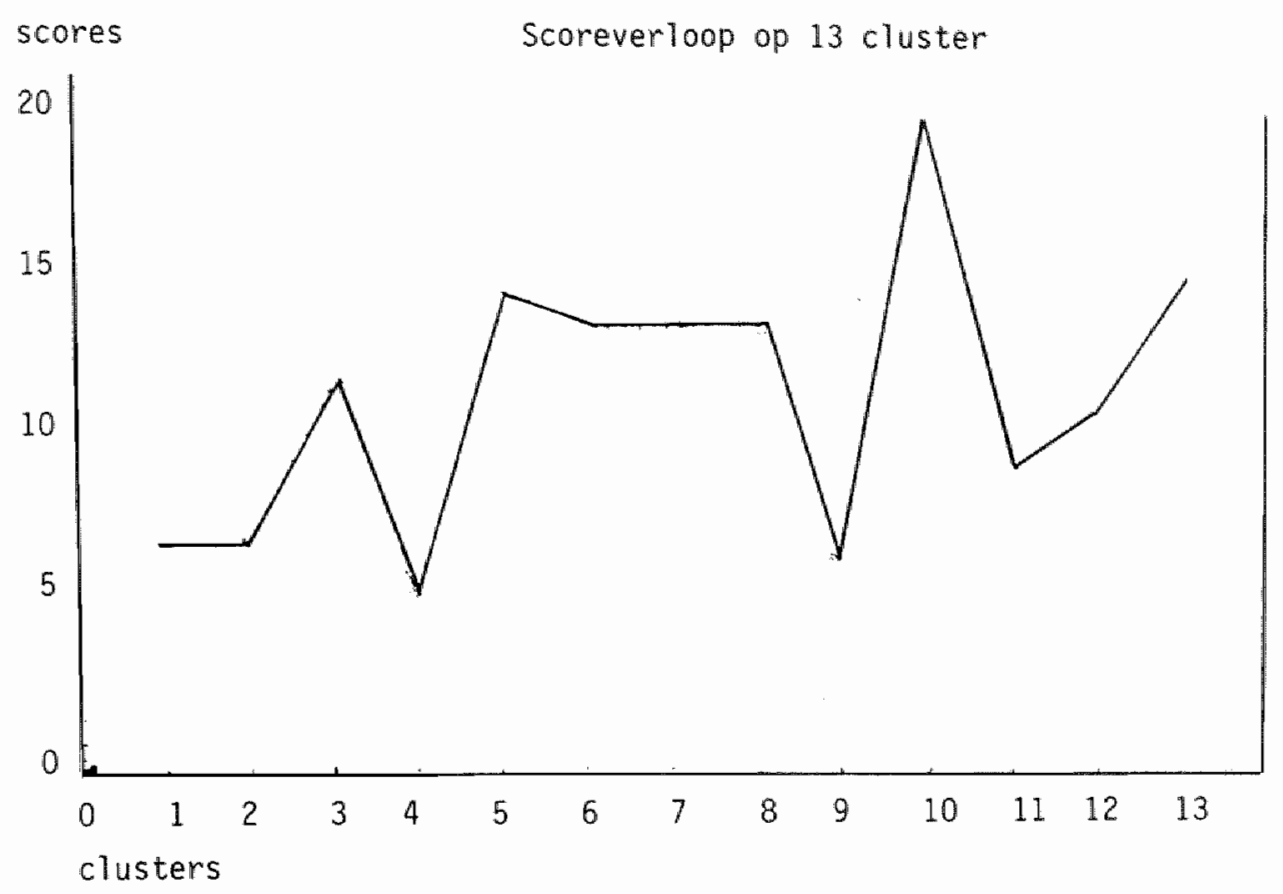

Figuur 4. Scoreverloop op grenssituatieclusters

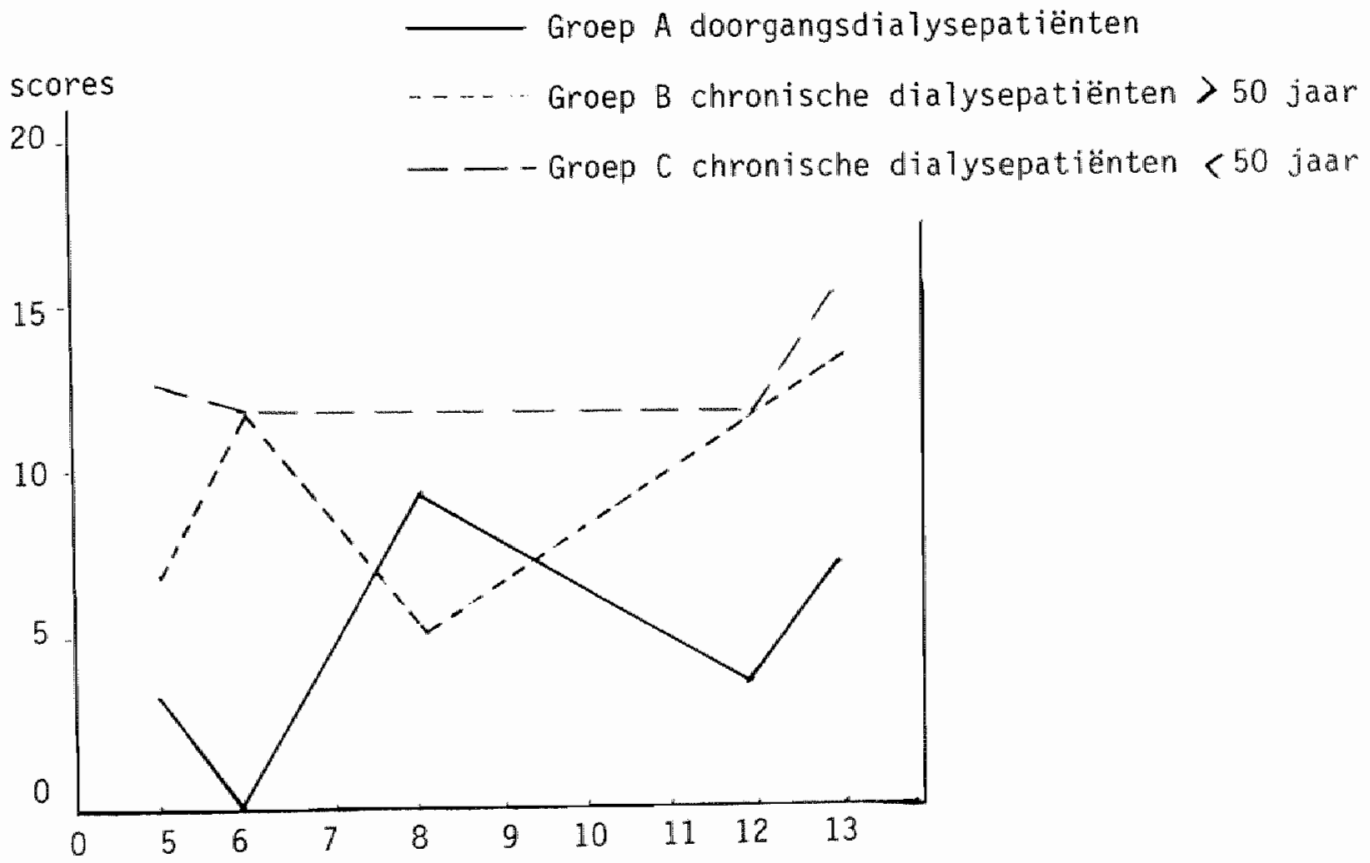


3.6.1. Resultaten t.a. W. hypothese I.

Het verschil tussen doorgangsdialysepatiënten (groep A) en chronische kunstnierpatiënten) 50 jaar (groep B) berekend over alle clusters, is in hoge mate significant $(p<.0001)$. Voor doorgangsdialysepatiënten (groep A) en patiënten die niet meer voor een transplantatie in aanmerking komen om andere redenen dan de leeftijd (groep $c$ ) is het werschil over alle clusters niet significant $(p<10)$. Ook tussen de aroepen $B$ en $C$ kon geen significant verschil worden aangetoond $(p<.40)$. Derhalve kan aan deze hypothese I geen steun worden verleend m.b.t. B↔C. 3.6.2. Resultaten t.a.v. voorspelling 3.5.1.1.

De onderzoeksresultaten m.b.t. cluster 3 - weerstand tegen de behandeling - wijzen wit dat er aantoonbare verschillen zijn tussen de groepen A, B en C, in die betekenis dat deze weerstand het grootst is bij de jongere leeftijdsgroep van niet meer voor een transplantatie in aanmerking komende patiënten $<50$ jaar. (Groep $c-43 \%)$, in vergelijking tot de twee andere groepen, resp. de oudere leeftijidsgroep van niet meer voor een transplantatie in aanmerking komende kunstmierpatiënten, $>50$ jaar (Groep B - 33\%), en de groep van doorgangsdialysepatiënten (Groep A $23 \%)$

De gevonden verschillen zijn echter klein en niet significant:

C $B(p<.70), C A(p<.10), B A(p<.70)$. Derhalve kan aan deze voorspelling slechts in geringe mate steun worden verleend. 


\subsubsection{Resultaten t.a.v. voorspelling 3.5.1.2.}

De onderzoeksresultaten met betrekking tot cluster 7 - verdringing ontkennen - wijzen uit dat er alleen sprake is van aantoanbare ver. schillen tussen de groepen $A \leftrightarrow B$ en $C * B$.

Uitingen m.b.t. verdringen en ontkennen komen het meest voar bij doorgangsdialysepatiënten en dialysepatiënten die om andere redenen dan de leeftijd ( $<50$ jaar) niet meer voor transplantatie in aanmerking komen (de groepen $\mathrm{A}$ en $\mathrm{C}$ beiden $46 \%$ ). Ze komen het minst voor bij de chronische oudere leeftijdsgroep $>50$ jaar (Groep B-10\%). De gevonden verschillen zijn significant voor de groepen $A>B<p<$ .0002 en $C>B \quad(p<.0002)$. Derhalve wordt aan deze voorspelling steun verleend voorzover het de aantoombare verschillen betreft met betrekking tot $A>B$ en $C>B$. Geen steun kan worden verieend aan de voorspelling met betrekking tat $A>C$.

\subsubsection{Resultaten t.a.v. voorspelling 3.5.1.3.}

In tegenstelling tot doorgangsdialysepatiënten (Groep A) en de dialysepatiënten behorend tot de jongere leeftijdsgroep zonder transplan-

tatieperspectief (Groep C) geven de chronische dialysepatienten $>50$ jaar (Groep B) blijk van een grote mate van aanvaarding van de dood $(80 \%)$.

Er is sprake van aantoonbare verschillen t.a.v. deze cluster (9), in die betekenis dat aanvadring van de dood het meest van toepassing is op de chronische oudere leeftijdsgroep $>50$ jaar (Groep B), vervolgens. op de chronische jongere leeftijdsgroep (Groep $c-26 \%$ ), en het minst wan toepassing is op doorgangsdialysepatiënten (Groep A - $10 \%$ ). De gevonden verschillen zijn significant voor $B>C \quad(p<.01)$, $B>A(p<.001)$ en niet significant voor $C>A(p<.10)$. Derhalve wordt aan deze voorspelling voldoende steun verleend. 
3.6.5. Resultaten t.a.v. voorspelling 3.5.1.4.

Bij alle groepen dialysepatienten liggen de scores op de cluster "hoop" en zich vastklampen aan medische mogelijkheden (cluster 10) zeer hoog.

Groep A $73 \%$, Groep B $50 \%$, Groep C $90 \%$ (gem. $71 \%$ ). De onderzoeksresultaten met betrekking tot deze cluster wijzen uit dat er aantoonbare verschillen bestaan tussen de groepen C A B, in die betekenis dat de chronische jongere leeftijdsgroep zonder transplantatieperspectief zich (toch) het meest vastklampt aan hoop op verbetering van medische mogelijkheden, vergeleken met doorgangsdialysepatiënten en chronische dialysepatiënten behorend tot de oudere leeftijdsgroep. De gevonden verschillen zijn significant voor $A>B(p<.05), c>B(p<.01)$ en niet significant voor $c>A(p<.50)$. Derhalve wordt aan deze voorspelling voldoende steun verleend.

3.7. Resultaten t.a.v. hypothese II en de daaruit afgeleide voorspellingen $3.5 .2 .1 . t / m 3.5 .2 .9$.

3.7.1. Resultaten t.a.v. hypothese II.

De onderzoeksresultaten met betrekking tot de grenssituatieclusters tonen aan dat patiënten behorend tot de groep dialysepatiënten <50 jaar zonder transplantatieperspectief (Groep C) de hoogste scores behalen op deze clusters $(5,6,8,12$ en 13 , zie tabel 3).

Dialysepatienten zonder transplantatieperspectief $<50$ jaar blijken t.a.v. het total van deze grenssituatieclusters signi- 
ficant te verschillen met doorgangsdialysepatiènten, C \A $(p<.05)$

Geen significant verschil kon worden aangetoond voor de verschillen tussen de dialysepatiënten zonder transplantatieperspectief $<50$ jaar, en de oudere - chronische - leeftijdsgroep $>50$ jar, $c>B \quad(p<.70)$.

Aan hypothese II met betrekking tot het total der grenssituatieclusters kan slechts steun worden verleend voorzover het de voorspelde verschillen betreft tussen de groepen $C$ en $A$.

\subsubsection{Resultaten t.a.v. voorspelling 3.5.2.1.}

De onderzoeksresultaten tonen aan dat het voorspelde verschil betmeffende de beleving van social isolement tussen dialysepatiënten zonder transplantatieperspectief $<50$ jaar (Groep C), en doorgangsdialysepatiënten (Groep $A)$, significant is $(p<.01)$. Derhalve kan aan deze voorspelling voldoende steun worden verleend.

3.7.3. Resultaten t.a.v. voorspelling 3.5.2.2.

De onderzoeksresultaten tonen aan dat het voorspelde verschil betreffende de beleving van sociaal isolement tussen dialysepatiënten zonder transplantatieperspectief $<50$ jaar (Groep C) en de oudere - chronische - leeftijdsgroep $>50$ jaar (Groep B) significant is, $C>B(p<.05)$.

Derhalve kan aan deze voorspelling voldoende steun warden verleend.

3.7.4. Resultaten t.a.v. voorspelling 3.5.2.3.

De onderzoeksresultaten tonen aan dat het voorspelde verschil betreffende de beleving t.a.v. angst voor de dood tussen dialyse- 
patiënten zonder transplantatieperspectief $<50$ jaar (Groep C) en doorgangsdialysepatienten (Groep A) niet significant is, c) $A(D<.70)$.

Derhalve kan geen voldoende steun worden verleend aan deze voorspelling.

3.7.5. Resultaten t.a.w. voorspelling 3.5.2.4.

De onderzoeksresultaten tonen aan dat het voorspelde verschil met betrekking tot beleving van angst voor de dood tussen dialysepatiënten zonder transplantatieperspectief $<50$ jaar

(Groep C) en de oudere - chronische - leeftijdsgroep $>50$ jaar

(Groep B) significant is, $C>B(p<.02)$.

Aan deze voorspelling kan voldoende steun worden verleend.

3.7.6. Resultaten t.a.v. voorspel1ing 3.5.2.5.

De onderoeksresultaten tonen aan dat het voorspelde verschil met betrekking tot de beleving van wanhoop en hopeloosheidsgevoelens tussen dialysepatiënten zonder transplantatieperspectief $\leqslant 50$ jaar (Groep C) en doorgangsdialysepatiënten (Groep A) significant is, C>A $(p \leqslant .05)$.

Derhalve kan aan deze voorspelling voldoende steun worden verleend.

3.7.7. Resultaten t.a.v. voorspelling 3.5.2.6.

De onderzoeksresultaten tonen aan dat het voorspelde verschil met betrekking tot de beleving van wanhoop en hopeloosheidsgevoelens tussen dialysepatiënten zonder transplantatieperspectief $<50$ jaar en de - chronische - oudere leeftijdsgroep $>50$ jaar niet significant is, $c>B \quad(p<.50)$. 
Derhalve kan deze voorspelling niet voldoende worden ondersteund.

3.7.8. Resultaten t.a.v. voorspelling 3.5.2.7.

De onderzoeksresultaten tonen aan dat het yoorspelde verschil

met betrekking tot het uiting geven aan suicidale gevoelens

of neigingen tussen dialysepatiënten met transplantatieperspectief (doorgangsdiaiysepatiënten, Groep A) en de - chronische oudere leeftijdsgroep, zonder transplantatieperspectief (Groep B) significant is $B>A(p<.01)$.

Derhalve wordt aan deze voorspelling voldoende steun verleend.

3.7.9. Resultaten t.a.v. voorspelling 3.5.2.8.

De onderzoeksresultaten tonen aan dat het voorspelde verschil met betrekking tot het uiting geven aan suïcidale gevoelens of neigingen tussen dialysepatiënten met transplantatieperspectief (doorgangsdialysepatiënten, Groep A) en dialysepatiënten zonder transplantatieperspectief $<50$ jaar significant is, $C>A(p<.01)$.

Derhalve kan aan deze voorspelling voldoende steun worden verieend.

\subsubsection{Resultaten t.a.y. voorspelling 3.5.2.9.}

De onderzoeksresultaten tonen aan, dat het voorspelde verschil met betrekking tot het uiting geven aan minderwaardigheidsgevoelens tussen dialysepatiënten met en zonder transplantatieperspectief significant is, B en $C>A(p<.05)$. Derhalve wordt aan deze voorspelling voldoende steun verleend. 


\subsection{Discussie.}

\subsubsection{Doorgangsdialysepatienten:}

Op basis van de resultaten van het vooronderzoek en daamee getoetste hypothesen zijn doorgangsdialysepatiënten, Groep A, te typeren als een groep die weinig moeite heeft met de behandeling als zodanig.

Voor deze groep geldt een grotere mate van angst voor de apparatuur dan bij chronische kunstnierpatiënten. Het is waarschijnlijk dat deze angst afneent naarmate men langer spoelt.

Er is weinig manifeste waardering voor ziekenhuis en afdeling. Mogelijk dient dit in verband gebracht te worden met gevoelens van onvrede in het algemeen over de levenssituatie, afhankelijkheidsgevoelens ten aanzien van de afdeling, kritiek over het lange uitblijven van een verwachte transplantatie, toenemende irritatiegevoelens over alles wat opgelegd, en niet altijd begrepen wordt (voorschriften, beperkingen). Het leggen van dit verband houdt de veronderstelling in dat deze erwaren afhankelijkheid verzet oproept die niet altijd geuit wordt of kan worden, al of niet op grond van agressieverdringing (Kaplan de Nour, 1971). De doorgangsdialysepatienten lijken zich in sociaal opzicht niet geïsoleerd te voelen. Men leeft met duidelijke verwachtingen en hoop op een transplantatie, ook al gebeurt dit alleen niet snel genoeg. Met de dood wordt in feite geen rekening gehouden, of men verdringt de gevoelens dienaangaande.

\subsection{2. "Chronische"t dialysepatiënten.}

Chronische dialysepatiënten - de oudere leeftijdsgroep > 50 jaar, Groep B, accepteren hum toestand als onvermijdelijk. Men weet dat er geen ander alternatief is dan de dood en aanvaardt ook deze mogelijkheid wanneer dialyseren niet meer mogelijk zou zijn. 
Verzet of angst woor de dood komt manifest binnem deze groep slechts sporadisch voor.

Men lijkt zich minder vast te klampen aan nieuwe medische mogelijkheden. De huidige situatie lijkt door hen aanvaard te worden zoals deze is, uitgezonderd enkele patiënten vit deze leeftijdsgroep die zich wanhopig witen over het feit dat $z i j$ nu warschijnlijk te oud zijn en enkele jaren geleden meer kans zouden hebben gehad op een transplantatie. Binnen deze groep zijn enkele patiënten, die het achteraf betreuren zich te hebben laten dialyseren. Gezien het uiten van suicidale gedachten, lijkt voor hen de kwaliteit van het toegevoegde leven te gering te zijin.

\subsubsection{De jongere leeftijdsgroep $<50$ jaar, zonder transplanta- tieperspectief.}

Deze groep $C$ is te typeren als patiënten die zich "tussen wal en schip" voelen. Zij kunnen zich over het geheel genomen niet neerleggen bij het feit niet voor een transplantatie in aanmerking te komen. Het is warschijnlijk dat de grotere mate van weerstand tijdens de behandeling in vergelijking tot de andere (chronische) groep samenhangt met de verwachtingen die men t.a.v. een transplantatie heeft gehad. Zij ervaren hun toestand als meer vitzichtsloos en witen in hoge mate hun wanhopigheid hierover. Het merendeel van de natiënten uit deze groep lijkt de gedachte aan doodgaan niet te aanvaarden, c.q. niet toe te 
komen aan verwerking van gevoelens dienaangaande. In tegenstelling tot de andere groepen worden bij deze groep meer aanwijzingen voor insufficiëntiegevoelens en sociaal isolement geregistreerd. Gegeven het verschil in dit opzicht met de andere groepen ( $A$ en $B$ ) 1ijkt het warschijnlijk dat patiënten die in hun verwachtingen t.a.v. een transplantatie zijn teleurgesteld, meer de neiging hebben zich terug te trekken, hiertoe wellicht ook gedwongen door een slechtere Vichamelijke conditie. Hopend en wanhopend tegelijkertijd wenst een aantal van de patiënten uit deze groep onder alle omstandigheden door te gaan met dialyseren.

Opmerkelijk is dat op de cluster "hoop op medische mogelijkheden" door alle groepen kunstnierpatiënten hoog werd gescoord, terwijl slechts bij doorgangsdialysepatienten (Groep A) deze hoop gerechtvaardigd is.

Aanwijzingen voor deze hoop blijken ook aanwezig bij chronische kunstnierpatiënten> 50 jaar. Hoewe 1 hun transplantatiemogelijkheden dubieus zijn geworden, blijven zij zich vastklampen aam - eventueel - nieuwe medische mogelijkheden. Het is waarschijnlijk dat (zie hiervoor ook de resultaten op cluster 13) gevoelens van hoop en wanhoop elkaar afwisselen, althans elkaar zeker niet uitsluiten. Hieruit blijkt dat het door Schmale (1972) genoende en omschreven "Giving-upgiven-up" syndroom niet zonder meer generalliseerbaar is over kunstnierpatiënten met en zonder transplantatieperspectief. 


\subsubsection{Carcinoompatiënten (vergelijkingsgroep).}

Tussen groep $D$, de vergelijkingsgroep van carcinoompatiënten onder bestralingsbehandeling en de drie onderscheiden groepen kunstnierpatiënten, blijken significante verschillen aantoonbaar (zie tabel 5). De overeenkomst met kunstnierpatiënten heeft betrekking op afzonderlijke factoren (zie tabel 3). Carcinoompatiënten hebben een meer positieve mening en attitude ten aanzien van behandeling en hulpverteners dam kunstnierpatiënten. Bijna de helft van hen blijkt zich vast te klampen aan de hoop op een succesvolle therapie. Toch worden binnen deze groep ook de meest uitgesproken gevoelens van wanhoop geregistreerd.

Suicidale gedachten werden niet geuit, noch aanwijzingen voor apparatuurangst (bestralingstherapie).

3.8.5. Samenvatting.

De scores van alle groepen op de clusters "angst voor de apparatuur" (cluster 1), "waardering voor de behandeling" (cluster 2), "steun van de partner" (cluster 4) en "het continueren van de behandeling onder alle omstandigheden" (cluster 11), blijken een grote mate van overeenkomst te vertonen (tabel 1 en 3). Dit gegeven komt overeen met de veronderstelling die vermeld werd in 3.4 .

Een belangrijk gegeven uit dit vooronderzoek is dat het daarbij gehanteerde uitgangspunt met betrekking tot het onderscheid tussen drie groepen kunstnierpatiënten niet of onvoldoende bevestiging vindt. 
De facto geldt dit onderscheid wel t.a.v. transplantabele kunstnierpatiẻnten (doorgangsdialysepatiënten, groep A) en de niet meer voor een transplantatie in aanmerking komende kunstriferpatiënten (de groepen $\mathrm{B}$ en $\mathrm{C}$ ).

ook t.a.v. het tweede onderdeel van onze probleemstelling - de veronderstelling vanuit het concept grenssituatie b] ijkt differentiatie slechts mogelijk tussen transplantabele en niet transplantabele kunstnierpatiënten. Hieruit kan worden geconcludeerd dat het definitieve onderzaeksontwerp naar de belevingsaspecten wan kunstnierpatiënten gebaseerd dient te worden op het verschil tussen het al of niet (meer) in aanmerking komen voor een niertransplantatie. Uit de gecanstateerde verschitlen m.b.t. de belevingsaspecten met en zonder transplantatieperspectief blijkt dat het beleven van de kunstnierbehandeling als grenssituatie verband houdt met het niet, of niet meer hebben van tramsplantatieperspectief.

Aan de veronderstelling betreffende de belevingsasnecten van het verkeren in een grenssituatie blijkt een belangrijk element te moeten worden toegevoegd $n$. de hoop die ondanks alles aanwezig blijkt.

Grenssituatiebelevingen blijken niet zonder meer te generaliseren met betrekking tot kunstnierpatiënten in het algemeen. Mocelijk hebben de beschrijvingen van auteurs als Freyberger (1968), Mc. Kegney (1971), Fox (1970), Kessel (1971) en Abram e.a. (1971) (zie 2,2) betreffende deze belevingen 
betrekking op patiënten zonder transpliantatieperspectief. Uit de door hen verstrekte gegevens is dit helas niet af te Teiden.

Gesteld kan worden dat de door bovengenoemde auteurs beschreven beleving van de kunstnierbehandeling een te eenzijdig, te somber beeld geeft, en niet representatief is voor de kunstnierpatiënt in het algemeen, maar primair van toepassing is op kunstnierpatiënten zonder transplantatieperspectief. 


\subsection{Conclusies:}

Dat de wijze waarop kunstnierpatiënten hun behandeling psychisch beleven en verwerken samenhangt met de werschillen in behandelingssituatie, geldt well voor de verschillen tussen doorgangsdialysepatiënten en chronische kunstnierpatiënten enerzijds, en doorgangsdialysepatiënten en dialysepatiënten zonder transplantatieperspectief anderzijds, resp. de groepen $A \leftrightarrow B$ en $A \leftrightarrow C$.

Niet kon aangetoond worden dat deze verschillen ook van toepassing zijn op chronische kunstnierpatiënten $>50$ jaar, en kunstmierpatiënten zonder transpliantatieperspectief $<50$ jaar.

De verschillen in belevingssituatie hangen dus samen met het al of niet (meer) hebben van transplantatieperspectief. De grootste verschilien in de beleving en verwerking van de kunstnierbehandeling tussen transplantabele (Groep A) en niet (meer) transplantabele kunstnierpatiënten (Groep B en C) hebben betrekking op:

a. het ervaren van sociaal isolement,

b. het ervaren van minderwaardigheidsgevoelens,

c. aanvaarden van de dood,

d. hoon, vastklampen aan medische monelitheden, e. het ervaren van wanhoop en gevoelens van hopeloosheid.

Samenvattend kan het volgende worden geconcludeerd:

1. Psychologisch dient er bij dialysepatiënten wat betreft hun belevingsaspecten onderscheid te worden gemaakt tussen transplantabele en niet meer voor een transplantatio in 
aanmerking komende kunstnierpatiënten, resp. doorgangsen chronische dialysepatiënten.

2. Angst voor de apparatuur doet zich woor bij een minderheid van de patiënten en is overwegend van voorbijgaande aard. Voorzover deze angstgevaelens worden geuit, is dit met name gedurende de eerste fase van de kunstnierbehandeling (1 - 3 maanden).

3. Weerstand en verzet tegen de behandeling wordt vooral aangetraffen bij de chronische dialysepatiënten, d.w.z. zij, die niet meer voor een transplantatie in aanmerking komen.

4. Enerzijds heeft de huwelijkstelatie vak te lijden onder de gevolgen van de behandeling; anderzijds vindt éên derde van de gehuwde patiënten dat deze relatie goed gebleven is of verbeterd door de ervaren steun van de partner.

5. Ontkennings - en verdrinningsmechanismen doen zich met name voor bij de doorgangsdialysepatiënten en patiênten die wel met de verwachting op een transplantatie hebben geleefd, mar hiervan moeten afzien.

6. Dver angstgevoelens voor de dood wordt weingig expliciet. gesproken, verzet tegen een mogelijke dood geldt vooral voor de transplantabele kunstnierpatiënten (Groep A) en chronische kunstnierpatiënten van jongere leeftijd. De patiënten die een mogelijke dood lijken te hebben aanvaard, worden in meerderheid aangetroffen bij de oudere 
leeftijdsgroep van chronische kunstrierpatiënten, evenals bij de vergelijkingsgroep van carcinoompatiënten.

7. Opvallend hoog zijn de aanwijzingen voor de hoop en het zich vastklampen aan medische mogelijkheden bij alle groepen kunstnierpatiēnten. Met uitzondering van Groep $B$ behalen alle kunstnierpatiënten de hoogste scores op deze cluster.

8. Suicidale gedachten of neigingen komen slechts incidenteel voor in de groep van chronische kunstnierpatiënten. De onderzoeksresultaten sluiten overigens niet wit dat suïcidale tendenzen worden ervaren maar niet of nauwelijks geutit.

9. Gevoelens van wanhoop en hopeloosheid doen zich in hoge mate voor bij die patiënten die aanvankelijk wel, later niet meer voor een transplantatie in aanmerking komen (Groep C). In dit opzicht vertonen zij geen onderscheid met de vergelijkingsgroep van carcinoompatiënten. 


\section{ONDERZOEK}

4.1. Inleiding.

In het vooronderzoek werd een conceptmodel van dertien op face-value geformuleerde clusters gehanteerd betreffende kenmerken van dialysepatiënten. De bedoeling hiervan was de te verwachten verschilien in de belevingssituatie random de kunstnierbehandeling te relateren aan verschillen in behandelingssituatie. Daartoe werd onderscheild gemaakt tussen drie groepen kunstniernatiënten: de resp. doorgangsdialysepatiënten met transplantatieperspectief, chronische dialysepatienten zonder transplantatieperspectief ouder dan 50 jaar en chronische dialysepatiënten zonder transplantatieperspectief jonger dan 50 jaar.

De onderzoeksresultuten van het vooronderzoek bevestigen de veronderstelling, dat ten aanzien van de belevingswereld van kunstnierpatiënten onderscheid dient te worden gemaakt tussen patiënten met en patiënten zonder transplantatieperspectief. Hoewe met betrekking tot deze laatste categorie van niet (meer) transplantabele kunstnierpatiënten geen significante verschillen konden worden aangetoond tussen patiënten jonger dan 50 jaar en patiënten ouder dan 50 jaar ten aanzien van het totaal der clusters (tabel 5) is het van belang deze twee groepen patienten vanuit de aangegeven leeftijidsgrens te onderscheiden. De gegevens vanuit het vooronderzoek rechtvaardigden namelijk de veronderstelling, dat, hoewel er overeenkomstine belevinosaspecten aantoonbaar zijn, bij patiënten jonger dan 50 jaar en ouder dan 50 jaar (zie tabel 3 en 5 ) de verschillen t.a.v. een aantal afzonderlijke clusters samenhangen met de redenen of gehanteerde indicaties om niet (meer) voor een transplantatie in aamerking te komen. Enerzijds kan de leeftijd boven 50 jaar als een medische contra-indicatie 
worden aannemerkt, anderzijids kunnen voor patienten beneden de 50 jaar o.a. Systemaandoeningen en het verhoogde risico op complicaties als contraindicaties voor een transplantatie gelden.

op basis van de gegevens uit het in het wooranderzoek gehanteerde conceptmodel kan nu met betrekking tot de verschillen voor de drie onderscheiden groepen kunstnierpatiënten het wolgende operationele model worden geformuleerd.

Doorgangsdialysenatiënten ervaren weinig weerstandsgevoelens t.a.v. de behandeling, praktisch aeen gevoelens van sociaal isolement, geen minderwardigheidsgevoelens vanwege de behandeling en zij distantiëren zich van gevoelens met betrekking tot aanwarding wan de dood.

Hun belevingswereld wordt in sterke mate bepald door gevoelens van hoop en het zich vastkjampen aan medische mogelijkheden.

Chronische kunstnierpatiënten zonder transplantatieperspectief en ouder dan 50 jaar ervaren weinig angstgevoelens met betrekking tot de apparatuur. zij ervaren s]echts in geringe mate gevoelens van sociaal isolement, hebben weinig neiging tot verdringen of ontkennen (afweermechanismen) en ervaren weinig angstgevoelens t.a.v. dood en sterven. In hun belevingswereld wordt de dood als mogelijkheid aanvaard. 
Chronische kunstnierpatiënten zonder transplantatieperspectief maar jonger dan 50 jaar, ervaren weinig angstgevoelens met betrekking tot de apparatuur. In vergelijking met de andere groepen kunstnierpatiënten tonen zij minder wardering en meer weerstandgevoelens t.a.v. de behandeling en het ziekenhuis, ervaren minder steun van de partner en ervaren meer gevoelens van sociaal isolement en angst voor de dood. Hun belevingswereld wordt sterk bepaald door de afwisseling van gevoelens van hoop en wanhoop.

De meest van toepassing zijnde belevingsaspectem kunnen schematisch worden weergegeven.

Schema 1:

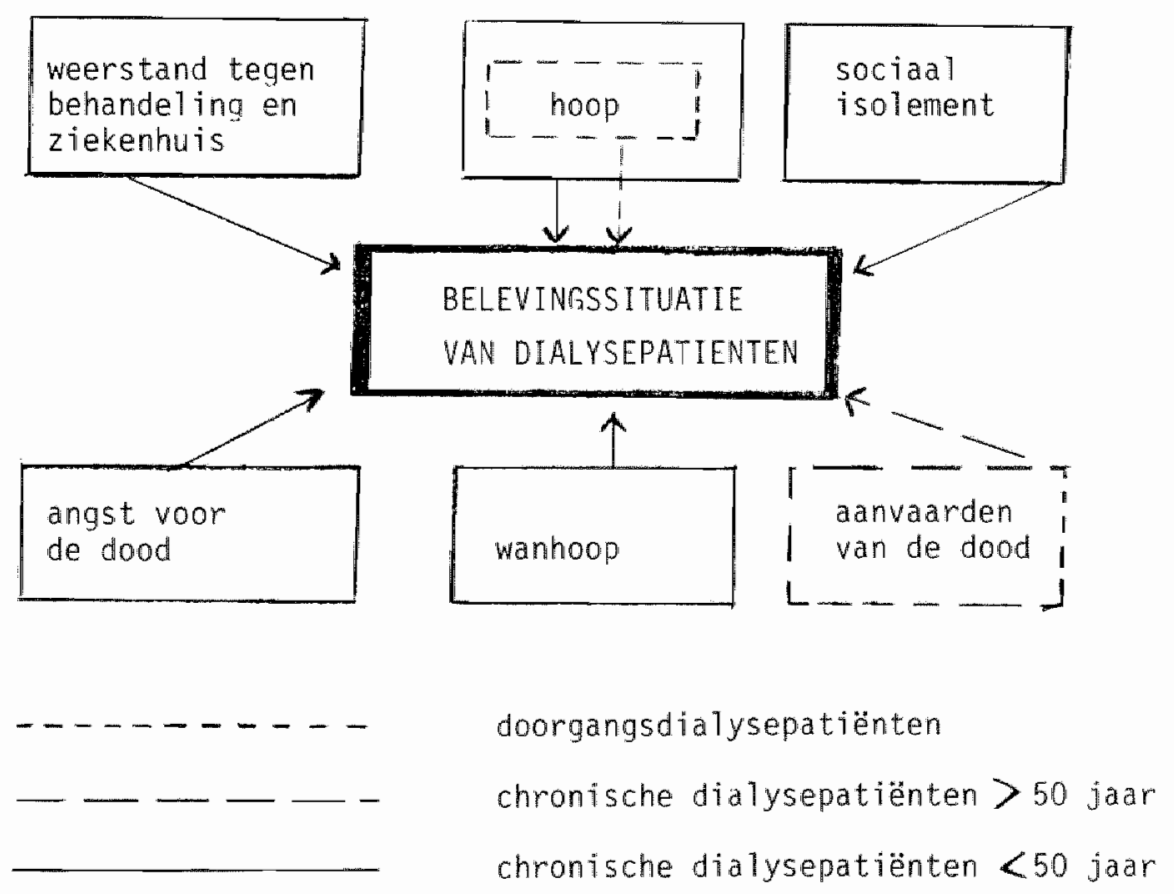




\subsection{Probleemstelling.}

De kunstmierbehandeling kan worden omschreven als een voorbeeld van geavanceerde medische zorgverlening. Van deze behandeling kan echter voorondersteld worden, dat hij gepaard gat met veranderingen in de belevingswereld van de betrokken patiënten. Het voorliggende onderzoek is er op gericht meer inzicht te verkrijgen in deze veranderde belevingswereld en in de betekenis wan factoren die deze belevingswereld benalen.

Daarbij wordt uitgegaan van de in het vooronderzoek reeds bevestigde veronderstelling, dat het al of niet (meer) transplantabel zijn, van invloed is op de wijze warop de kumstnierpatiënt psychisch deze behandeiling ondergat. Deze veronderstelling wordt met name uitgewerkt in het vragenlijst-en uitsprakent ijstonderzoek.

\subsection{Onderzoekopzet.}

In hoofdstuk 3 werden de onderzoeksresultaten beschreven, gebaseerd op een steekproef van dertig kunstnierpatiënten wit één dialysecentrum (Maastricht). op basis daarvan was tet mogelijk eem operationele definiering te geven van drie onderscheiden groepen kunstnierpatiënten (4.1.).

Om na te gaan of ook bij een representatieve steekproef van kunstnierpatiënten wit verschillende nederlandse kunstniercentra de conclusies uit het vooronderzoek konden worden gehandhafd (pag. $38 \mathrm{t} / \mathrm{m}$ 40) zullen wit deze canclusies en het gegeven operationele model betreffende de drie onderscheiden groepen kunstnierpatienten hypothesen worden afgeleid, die in dit hoofdonderzoek zullen worden getoetst (zie hierwoor de uitsprakenlijst).

Ondat het miet uitgesloten is, dat ook andere variabelen dan de verschillen in behandelingssituatie van invloed zijn op de belevingswereld van de kunstnierpatiënt worden in dit onderzoek een aantal variabelen ter onderzoek toegevoegd o.a. werschillen in leeftijd, man/vrouw, gehuwd/ongehuwd, beroepsniveau en dialyseduur (zie hiervoor de vragenlijst). 
Het voorliggende onderzoek is explaratief van opzet. Over de psychologische implicaties van de kunstnierbehandeling bestaan ook na ongeveer 15 jadr dialyseren (en transplanteren) nog weinig bruikbare theorièn. Kaplan de Nour (1978) die op het terrein van de psychiatrische en psychologische aspecten van de kunstnierbehandeling als een deskundige bij uitstek mag worden beschouwd, vermeldt in een uitvoerig literaturaverzicht betreffende een 120-tal publikaties, dat door gebrek aan coördinatie en samenwerking betrekkeijk veel fragmentarisch materiaal is verzameld, mar dat door de beperking van de samples en de diversiteit van daarbij gehanteerde criteria aan deze onderzoeken nauwelijks conclusies kumnen worden verbonden met algemene geldigheidswarde.

Het onderzoeksinstrumentarium is samengesteld uit drie onderdelen (zie methode wan onderzoek 4.4.). De vragenlijst dient om aan de hand van een adal toegevoegde variabelen inzicht te verkrijgen in de belevingswereld van wel en niet transplantabele patiënten. Met de uitsprakenlijst als uitgangspunt wordt getracht een aantal in clustervorm verzamelde uitspraken van kunstmierpatienten te vertalen in 'dimensies' of factoren van ziektebeleving.

De semantische differentiaal werd toegevoegd om te onderzoeken of deze schaal een bijdrage levert tot het inzicht in de belevingswereld van kunstmierpatieinten in het algemeen.

Onze opzet is derhalve, middels exploratief onderzoek, een bijarage te leweren tot een theorlevorming die verder in toetsbare varm dient te worden bewerkt. Bij de bespreking van de onderzoeksinstrumenten (4.4.) zullen de gestelde hypothesen en onderzoeksuragen steeds afzonderlijk worden geformuleerd. Voor het verkrijgen van de hiervoor noodzakelijke gegevens werd gekozen voor de volgende onderzoekprocedure: 
Aan tweehonderd kunstnierpatiënten wit zesthen centra werd medewerking gevaagd om deel te menen aan een onderzoek naar psycho-sociale aspecten van nierfunctievervangende behandeling. Binnen deze steekproef waren zowel doorgangsdialysepatiènten (transplantabel), chronische dialysepatiënten ouder dan 50 jear en chronische dialysepatiënten jonger dan 50 jaar vertegenwoordigd. Bij een totad aantal Rederlandse kunstnierpatiënten wan ongeveer 1400 , verdeeld over 38 centra, is deze steekproef in ieder geval in kwantitatief opzicht representatief. Gepoogd werd dit ook in kwalitatief opzicht te realiseren. om van kunstnierpatiënten de medewerking te verkrijgen voor een onderzoek naar de psychosociale aspecten van nierfunctievervangende behandeling werd naar een mogelijkheid gezocht warbij in korte tijd zoveel mogelijk kunstnierpatiënten konden worden bereikt.

Deze gelegenheid deed zich voor tijdens de jaarlijks met medewerking van de Nierstichting georganiseerde vacantiereizen.

Sinds het begin van de activiteiten van de Sociale Commissie van de nierstichting heeft het organiseren van korte (vierdaagse) vliegvacanties in het buitenland voor patiënten en hun partners - tussen twee dialysebehandelingen in - een belangrijk onderdeel gevormd van haar werkzaamheden (Jaarverslag van de Nierstichting Nederland, 1974, pag. 14). Het aantal viuchten is sinds de eerste serie van vijf in 1972 steeds toegenomen.

Elke groep van ongeveer 50 patiënten en familieleden wordt begeleid door een arts en eem drietal verpleegkundigen.

Zo maken jaarlijks 250 - 300 patiënten en hun begeleidende familieleden gebruik van deze vrij unieke vacantiemogelijkheid.

Pas de laatste jaren neemt dit aantal iets af omdat tegenwoordig ook langdurige vacantiereizen met dialysemogelijkheden op het programma staan. Ondat de Nierstichting deze reizen subsidieert zijn er in principe geen finan-

* Emstig zieke patiënten vallen buiten deze steekproef. 
ciele belletselen voor de deelname hieraan.

In denografisch opzicht is de spreiding ideal. Platteland en stad zijn

evenredig vertegenwoordigd en dit geldt tevens voor de provinclale spreiding.

De leeftijd van de deelnemers loopt uiteen van ongeveer 18 - 70 jaar (voor

kinderen worden aparte reizen georganiseerd).

Deelname van het aantal vrouwelijke en mannelijke patiënten kan niet bij wooraat worden woorspeld, dit geldt ook voor het aantal gehuwden en ongehuwden. In de periode mei/juni 1978 deed zich in Sorrento (Italië), waar ruim tweehonderd kunstnierpatiënten met hum begeleidende familieleden een korte vacantie doorbrachten, voor de onderzoeker de gelegenheid voor aan vijf achtereenvolgende groepen van ongeveer veertig patiënten, medewerking voor dit onderzoek te vragen na hen over het doel wan dit onderzoek te hebben geinformeerd.

Dit gemotiveerde verzoek om medewerking werd nog eens herhaald in het blad D.I.A. . het orgaan van de Nierstichting Nederland.

In aansluiting op deze introductie werden aan 200 patiënten drie stel formulieren gestuurd, een vragenlijst, een uitsprakenlijst en een semantische differentiaal (Bijlagen III, IV en V). Van de aan 200 patiënten verstuurde formulieren werden er 154 geretourneerd, een response van $77 \%$, hetgeen als hoog kan worden a angemerkt.

Van 14 respondenten konden de gegevens niet in het onderzoek worden opgenomen, ondat niet alle gegevens waren ingevuld. Met name de semantische differentidal bleek in dit opzicht problemen te hebben opgeleverd.

Uiteindelijk werden de gegevens van 140 patiënten, d.w.z. ongeveer $10 \%$ van de totale kunstnierpopulatie in Nederland, in het onderzoek betrokken:

- doorgangsdialysepatiënten

$(n=50)$

- chronische dialysepatiënten ouder dan 50 jaar $(n=47)$

- chronische dialysepatiënten jonger dan 50 jaar $(n=43)$ 


\subsection{Methode wan anderzoek.}

On twee redenen, de een van methodologische, de ander van meer practische aard werd besloten geen gebruik te maken van het in het vooronderzoek gehanteerde semi-gestructureerde interview.

Ondanks de betere motiverende functie van open interviewragen, blijft het moellijk conclusies te trekken over de frequentie waarin bepalde antwoordcategorieën of inhoudselementen bij de onderzochte respondenten voorkomen. Segers J.K.G. (Sociologische onderzoeksmethode, Assen, 1975) wijst op de gerince betrouwbaarheid van de interviewmethoden en voegt hieraan toe, dat de scoring van antwoordcategorieën te veel samenhangt en afhankelijk isvanhet verschil in verbaliserend vermogen der proefpersonen, waarmee ook de waarde van de variabele afhankelijk wordt van dit verschil in verbaliseren.

De eigen ervaringen met de in het vooronderzoek gehanteerde interviewmethode bevestigden dit bezwaar ook al kan daaraan enigszins tegemoet gekomen worden door een zeer strakke scoringsmethode op basis van inhoudsanalyse.

Echter ook om praktische redenen werd de voorkeur gegeven aan een andere wijze van dataverzameling.

Een onderzoek bij een 5 teekproef van 140 proefpersonen, verdeeld over 16 verschillende centra leat beperkingen op in de keuze van de methode van dataverzameling. Afgezien van het feit, dat het praktisch ondoenlijk was een dergelijk aantal patiënten te interviewen, bleek reeds in het vooronderzoek bij 40 patiënten hoe tijidrovend het verwerken, ordenen en scoren der gegevens, op basis van inhoudsanalyse, is.

Voor de dataverzameling van het hoofdonderzoek werden drie schalen geconstrueerd. 
namelijk drie varianten van ratingscaletechnieken:

- een vragen 1 ijst

- een uitsprakenlijst

- een semantische differential

Het gebruik van vragenlijsten en varianten daarvan is een veel toegepaste methode van dataverzameling in het sociaal-wetenschappelijk onderzoek. Vragenlijsten zijn geschikt voor informatiewerving gericht op registratie van percepties, meningen, gevoelens en motivaties.

Van de door Galtung beschreven negen methoden van dataverzamelingstechnieken behoren er drie tot het type van de vragenlijist (Galtung, 1967). De bruikbaarheid van vragenlijsten in een onderzoekssituatie hangt ten nauwste samen met de betrouwbaarheid ervan en een zeer zorguuldige samenstelling der items.

Zowel de vragen als gekozen antwoordmogelijkheden dienen zeer duidelijk te worden gesteld in die zim, dat ze door proefpersonen, die niet of nawelijks aan psycholonische onderzoeken zijn gewend, kunnen worden begrepen en zonder nroblemen kunnen worden ingevuld. Bij een proefserie van de drie in concept geconstrueerdeschalen bleek, dat de daarbij betrokken 20 patiënten weinig of geen oroblemen hadden met de vragen, witspraken of begrippen maar wel met de instructie van de semantische differential, die ma twee wijzigingen zijn definitieve vorm kreeg (voor de instructies bij de gebruikte schalen zie bijlagen III, IV en $V$ ).

Toch kan men zich afvragen of een vragentijstmethode wel de meest geëigende vorm is om relevante informatie te verkrijgen op vragen die als strikt persoonlijk kunnen worden beschouwd en wellicht ook ego-defensieve mechanisnen oogeroepen. 
Dit kan gelden voor vragen met een hoge delicatheidsgraad b.v. de opgenomen wragen i.v.m. "angst voor de dood", "het al of niet hebben van suifcidale neigingen en oevoelens", "het al of niet willen continueren wan de behandeling onder alle omstandigheden". Hoewel juist t.a.v. deze vragen een diepte-intervieuw meer in aanmerking komt, was op face value de openheid en bereidheid bij de respondenten om ook op deze wragen in te gaan zowel bij het vooronderzoek als de reeds aenoemde nroefserie met de schaalmethode aanteiding deze methode te handhaven.

\subsection{De vragenlijst.}

De opzet van dit onderzoeksgedeelte is om middels een enquête een aantal variabelen in verband te brengen met:

a. het belevingspatroon van de patiënt in kunstnierbehandeling in het algemeen.

b. de belevingssituatie van specifieke aroepen kunstnierpatiënten, te weten:

groep A: doorgangsdialysepatiënten met transplantatieperspectief

groep B: chronische dialysepatiënten ouder dan 50 jaar zonder tramsplantatieperspectief.

groep $C:$ chronische dialysepatiënten zonder transplantatieperspectief jonger dan 50 jaar.

In samenwerking met de capaciteitsgroep medische sociologie van de Rijksuniversiteit Limburg (met erkentelijkheid aan Drs. J. Diederiks) werd hiertoe een vragenlijst geconcipieerd.

Deze 1 ijst bestaat uit 18 items ter meting van 18 variabelen, elk met 5 antwoordcategorieèn per item (zïe bijlage III).

Tot deze 18 items behoren 2 informatieve wragen, ingevoegd om de respondenten te introduceren in dit - eerste - onderzoeksgedeelte betreffende afstand tot 
ziekenhuis en vakantiemogelijkheden.

De overige 16 vragen hebben betrekking op variabelen als: dialysedur. ervaring met psychische en matschappelijke begeleiding, verwachtingen t.a.v. psycho-sociale begeleiding, mening over medische en verpleegkundige behandeling, steun en begrio van partner(s), werksituatie, social isolement, insufficientiegevoelens, toekomstverwachtingen, verwachting t.a.v. dood en leven, verwachting over medisch-technische ontwikkelingen m.b.t. de kunstnierbehandeling, veranderingen in het levenspatroon, verwachting t.a.v. een niertransplantatie (mate van zekerheid, pasitieve/negatieve gevoelens en verwachtte tijdsduur) en mening t.a.v. de mogelijkheid tot beëindigen van de kunstnierbehandeling. 


\subsubsection{Onderzoeksuragen met betrekking tot de vragenlijst.}

De vragen van het vragenlijstonderzoek hebben betrekking op de relatie tussen een aantal afhankelijke variabelen van de vragenlijst en een aantal onafhankelijke variabelen als:

het behoren tot éen der onderscheiden groepen kunstrierpatiënten n.1.:

groep A: doorgangsdialysepatiênten

groep B: chronische dialysepatiënten ouder dan 50 jaar

qroep $C$ : chronische dialysepatiënten jonger dan 50 jaar,

leeftijdscategorie, geslacht, burgerlijke status, opleidingsniveau en dialyseduur.

Met betrekking tot het verband tussen beide genoemde soorten variabelen zijn in tabel 9 een aantal relaties nader gespecificeerd.

Eike afhankelijke variabele wordt in het onderzoek gerelateerd aan zes onafhankelijke variabelen. Waar in deze specificatie sprake is van afhankelijke 'variabelen' zijn bedoeld de vraqenlijstitems welke op het betreffende onderwerp betrekking hebben (tabel 10).

Ter beantwoording van de onderzoeksvragen met betrekking tot deze relatie werden een aantal statistische bewerkingen uitgevoerd warvan de resultaten verwerkt werden in paragraaf 4.5.3. 


\subsubsection{Resultaten en bespreking van het vragenlijstonderzoek:}

de kwantitatieve gegevens.

In tabel 10 zijn de kwantitatiewe gegevens, wat betreft het aantal en de percentages respondenten, vastgelegd.

De verdeling der respondenten met betrekking tot de zes onafhankelijke variabelen is als volgt:

TABEL \&.

\begin{tabular}{|c|c|c|c|c|c|c|c|c|c|}
\hline \multicolumn{2}{|c|}{ Groepen N } & \multicolumn{4}{|c|}{ Leeftijd } & \multicolumn{2}{|c|}{ Geslacht } & \multicolumn{2}{|c|}{ Burgerlijke Stat } \\
\hline & & $30 j r$. & $30-40$ & $40-50$ & $50^{\circ}$ & M & W & Gehuwd. & Ongehuwd \\
\hline A & 50 & 30 & 7 & 13 & - & 12 & 38 & 37 & 13 \\
\hline B & 47 & - & - & - & 47 & 13 & 34 & 26 & 21 \\
\hline $\mathrm{C}$ & 43 & 7 & 16 & 20 & - & 20 & 23 & 30 & 13 \\
\hline Total & 140 & 37 & 23 & 33 & 47 & 45 & 95 & 93 & 47 \\
\hline
\end{tabular}

\begin{tabular}{c|c|c|c|r|c|c|c}
\hline & \multicolumn{3}{|c|}{ Opleiding } & \multicolumn{5}{c}{ Dialyseduur } \\
\hline Groepen & L.0. & Voortg.0p1 & Akad. & $1 \mathrm{jr}$. & $1-2$ & $2-3$ & $3 \mathrm{jr}$. \\
\hline A & 12 & 35 & 3 & 14 & 6 & 8 & 22 \\
B & 11 & 34 & 2 & 11 & 11 & 7 & 18 \\
C & 14 & 27 & 2 & 2 & 6 & 4 & 31 \\
\hline \multirow{2}{*}{ Totaal } & 37 & 96 & 7 & 27 & 23 & 19 & 71 \\
\hline
\end{tabular}


TABEL 9.

\begin{tabular}{|c|c|}
\hline Afhankelijke variabelen & Onaflhankelijke variabelen \\
\hline . & \\
\hline Psychosociale begeleiding & 1. Het behoren tot een der \\
\hline Steun van de partner & onderscheiden groepen kunst- \\
\hline Soctaal isolement & nierpatiënten: \\
\hline Insufficiëntiegevoelens & A: doorgangsdialysepatiënten \\
\hline Toekoms tverwachting & B: chronische dialysepat. $>50 \mathrm{jr}$. \\
\hline Houding t.a.v. eventuele dood & $\mathrm{C}$ : chronische dialysepat. $<50 \mathrm{jr}$. \\
\hline Verandering van leven & 2. Leeftijdscategorie \\
\hline Verwachting t.a.v. transplantatie & 3. Geslacht \\
\hline Beëindiging $v . d$. kunstnierbehandeling & 4. Burgerlijke Status \\
\hline Arbeidssituatie & 5. Opleidingsniveau \\
\hline & 6. Dialyseduur. \\
\hline
\end{tabular}


1. Hoe lang bent $u$ al it kunstnierpatiënt?

- minder dan $\frac{1}{2}$ jaar

- jaar - 1 jaar

$\begin{array}{rl}24 & 17 \\ 24 & 17 \\ 14 & 10 \\ 73 & 52\end{array}$

- 1 jaar - 2 jaar

- 2 jaar - 3 jaar

- 3 jaar of langer 4

10

52

2. Hoe ver woont u van

$Z$. H. en de plaats waar u gespoeld wordt?

- minder dan $5 \mathrm{~km}$

- tussen 5 - $10 \mathrm{~km}$

- tussen $10-20 \mathrm{~km}$

- tussen 20 - $30 \mathrm{~km}$

- $30 \mathrm{~km}$ of verder

3. Hoe verplaatst $\mathrm{u}$ zich naar het ziekenhuis en terug naar huis?

- per taxi

- per onbaar vervoer

- wordt gehaald of gebracht door kennissen of familie $12 \quad 9$

- rij met andere pat. mee 32

- rijzelf $21 \quad 15$

4. Hoe is uw mening over de psychische en maatschappelijke begeleiding binnen uw centrum?

- tevreden

- tamelijk tevreden

- geen mening of niet van toepassing

- tamelijk ontevreden 12

- ontevreden

5. Kunt $u$ in volgorde van belangrijkheid aangeven wat u van deze psychosociale begeleiding verwacht?

- hulp en ondersteuning via gesprekken

- bemiddelen bij en zorgen voor b.v. gezinszorg, hwisvesting, andere woning. 36

- materiële huipverlening regelen via bedrijfsver., andere uitkerende instanties of Nierstichting

- begeleiden van het gezin (thuis)

- informatie geven over de psycho-sociale kanten van de kunstnierbehandeling. 
i. Wat is uw mening over medische en verpleegk. behande-

ling binnen ww centrum?

- tevreden

- tame lijk tevreden

- geen mening

- tame iijk ontevreden

- ontevreden

$\begin{array}{rr}109 & 78 \\ 25 & 17 \\ 2 & 2 \\ 4 & 3 \\ 0 & 0\end{array}$

7. Kunt $u$ aangeven of en in welke mate u steun en begrip ondervindt van uw man/vrouw of partner?

- ik heb erg veel steun van mijn man/vrouw of partner

- ik heb tamelijk veel steun v. mijn man/vrouw, partmer

- ik weet het miet, ik heb er geen mening over, niet van toepassing

- ik heb tamelijk weinig steun v. mijn man/vrouw, partner

- ik heb helemaal geen steun v. mijn man/vrouw, partner

8. Werkt u momenteel?

- ik werk woll ledig

- ik werk gedeeltelijk

- ik werk niet meer (WAO, AAM, of andere uitkering)

- ik doe volledig de huishouding

- ik doe gedeeltelijk mijn huishouding maar heb hierbij wet hulp nodig

9. Bent u door uw ziekte en de kunstnierbehandeling geisoleerd geraakt van vrienden of kennissen?

- volledig

- enigszins

- niet van toepassing of geen verschil met de periode voor mijn ziekte

- weinig

- helemal niet

10. Bent $u$ zich als kunstnierpatiënt minderwaardig gaan voelen?

- erg minderwaardig

- tanelijk minderwarardig

- ik weet het niet

- nauwelijks minderwaardig

- helmaal niet minderwaardig 
11. Hoe ziet $u$ de toe- in

koms.t tegenoet?

- optimistisch $45 \quad 32$

- tamelijk optimistische $\quad 48 \quad 34$

- ik weet het niet $27 \quad 19$

- tamelijk pessimistisch $\quad 17 \quad 12$

- pessimistisch $\quad 32$

12. Hoe staat u t.a.v. een eventuele dood?

- ik ben er voortdurend bang voor

- ik ben er soms bang voor

- ik denk er niet over na of ik heb er geen mening over

- ik ben er niet zo bang voor 35

- ik heb me er helemaal mee verzoend

13. Verwacht $u$ zelf mee te maken dat door de verdere medisch-technische ontwikkeling de kunstnierbeh.

sterk vereenwoudigd wardt?

- ik verwacht dat zeker 74

- ik verwacht dat wel enigszins

- ik heb er geen mening over

- ik verwacht het nauwelijks 10

- ik verwacht het helemaal niet

14. In welke mate heeft de kunstnierbehandeling uw leven veranderd?

- ingrijpend

- enigszins

- ik weet het niet

- nauwelijks

- helemaal niet

15. Binnen welke termijn verwachtte u getransol. te worden toen u werd aangesloten op de kunstrier?

- binnen jaar

- binnen 2 jaar

- ik weet het niet

- binnen 3 jaar

- 3 jaar of langer 
16. Hoe zeker bent u van een transplantatie?

- ik reken er zeker on

- ik hoop het, maar weet het niet zeker

- ik betwijfel het, ik weet het niet

- ik heb er nauwelijks hoop op

- ik reken er niet (meer) op

$\begin{array}{rr}\% & \% \\ 39 & 27 \\ 26 & 18 \\ 17 & 12 \\ 7 & 5 \\ 48 & 34\end{array}$

17. Hoe stat u tegenover een eventuele transplantatie?

- ik verwacht er alles van

- is sta er niet zo optimistisch tegenover

- ik weet (nog) niet of ik wel getransplanteerd wil worden

- ik geef de voorkeur aan verder dialyseren boven een transplantatie

$14 \quad 10$

- ik kom niet meer voor een transplantatie in aanmerking.

18. Hebt $u$ er wel eens serieus over nagdacht om met de behandeling te stoppen omdat $u$ er geen heil meer in zag?

- vaak

- soms

- ik weet het niet

- zelden

- nooit

$\begin{array}{rr}4 & 3 \\ 21 & 15 \\ 2 & 1 \\ 13 & 9 \\ 100 & 71\end{array}$


1. Meer dan de helft wan de onderzochte kunstnierpatienten (52\%) dialyseert langer dan drie jaar. Hierbij dient te worden opgemerkt, dat volgens verwachting binnen dit aantal voorramelijk de chronische kunstnierpatiënten zijn vertegenwoordigd, d.w.Z.

- de oudere leeftijdsaroep

- patiënten die niet (meer) voor een transplantatie in aanmerking komen,

- patienten die de voorkeur geven aan verder dialyseren boven een transplantatie.

2. Van de anderzochte kunstmierpatiënten dialyseert $3 / 4$ betrekkelijk dichtbij hun woonplaats (binnen een straal van $30 \mathrm{~km}$ ). Dit werpt een gunstig licht op de spreiding wän kunstniercentra in ons land.

3. Bijna $3 / 4$ van de kunstnierpatiënten verplaatst zich per taxi naar huis en ziekenhuis. Dit aantal ligt beduidend hoger dan voomhands was verwacht. Van openbaar vervoer wordt zeer weinig gebruik genaakt. Er wordt in dit opzicht ruimschoots gebruik gemaakt van door ziekenfondsen verleende faciliteiten. 4. Ongeveer $70 \%$ van de patiënten uit zich tevreden tot tamelijk tevreden over de ontvangen psycho-sociale begeleiding binnen de centra.

5. Het is in dit verband van belang dat, gevraagd naar de prioriteit in deze begeleiding, het merendeel van de kunstnierpatiënten deze begeleiding verwacht, via hulp en ondersteuning door gesprekken en t.a.v. bemiddeling inzake gezinszorg en huisvesting.

Uit het geringe percentage (6) betreffende de materiële hulpverlening mag worden geconcludeerd, dat werkzaamheden en funktioneren van de matschappelijk werkenden slechts zeer partieel betrekking hebben op bemiddeling inzake materiële hulpverlening, mar vooral is toegespitst op de begeleiding door middel van ondersteunend gesprekskontakt.

6. Opvallend hoog ligt de "teuredenheidsscore' t.a.y. de medische en verpleegkundige zorg, $95 \%$ van de patiënten is tevreden tot tamelijk tevreden. Deze cijfers komen vrijwel overeen met de resultaten van een in 1977 in Maas- 
tricht gehouden ziekenhüs-enquete, war t.a.k. de verpleegkundigen een tevredenheidspercentage van $96 \%$ werd gemeten. T.a.v. de artsen was dit $78 \%$ (zie patientenenquete ziekenhils St.-Annadal, Mastricht, 1978).

7. Van de onderzochte kunstnierpatienten uit zich $3 / 4$ positief over de ondervonden steun wan zijn of haar partmer. Dit is een verheugend verschijnsel, vooral waar juist bij kunstnierpatiënten zo vaak in de titeratuur gewezen wordt op de grote betekenis van deze steun t.a.v. elkaar in een goede relatie. Het ontbreken van deze steun moet voor de betreffende kunstnierpatiënten ( $8 \%$ ) een schrijnend gemils zijn. Het hoge tewredenheidspercentage op deze faktor wijst er wellicht op - de literatuur over kunstnierpatiënten bevestigd dit - dat ziekte mensen niet hoeft te isoleren, mar dat juist door een aandoening - in dit geval een chranisch nierlijden - een bestaande relatie tussen (huwelijks)partners zich ook verdiepen kan.

8. Slechts $1 / 4$ van de kunstnierpatiënten werkt geheel of gedeeltelijk. Een volledige baan is bij kunstnierpatiënten een hoge witzondering (5\%). De helft van hen $(52 \%)$ valt binnen een uitkeringsregeling. Het ligt woor de hand dat dit, in vergelijking met cijfers uit de U.S.A. en Engeland, wrij hoge percentage verband houdt met de in Nederland bestaande uitgebreide sociale woorzieningen. 9. Dat ziekte, ook nierziekte lang niet altijd tot isolement behoeft te lijden blijkt uit het feit, dat siechts een minderheid van de kunstnierpatiënten (37\%) deze ervaring heeft en dan nog niet in dezelfde mate. Slechts $7 \%$ van de ondervraagde patiënten spreekt zich uitdrukkelijk over dit isolement uit.

10. In het verlengde van de gegevens over het isolement liggen de resultaten t.a.v. al of niet ervaren minderwaardigheidsgevoelens als gevolg van ziekte en de kunstnierbehandeling. Ongeveer $1 / 4$ van de patiënten ervaart deze gevoelens wel in mindere of meerdere mate, $3 / 4$ wan de patiënten in het geheel niet. 11. Van de onderzochte patiënten ziet $66 \%$ de toekomst optimistisch tot tameijk optimistisch tegemoet. Uit andere gegevens blijkt, dat dit optimisme betrekking heeft op b.v. een niertransplantatie en verbetering vam behandel ingsmogelijkheden (verbeterde apparatuur, kortere spoelingstijden, etc.). 
12. Zo er sprake is van angstgevoelens voor de dood, lijken deze een meer wisselend verloop te hebben.

De onderzoeksbevindingen in deze doen vemoeden, dat angst of vrees voor de dood bepald geen kenmerk is waardoor kunstrieppatienten zich onderscheiden van anderen.

13. De verwachtingen van kunstnierpatiënten t.a.v. verdere verbetering van behandel inqsmogelijkheden zijn tamelijk hoog gespannen. Zou ook hier alleen de "wens vader van de gedachte zijn?". Wellicht toch niet, alleen al gezien de ontwikkelingen in deze gedurende de laatste vijf jaar. Dan blijft nog de vraag wanneer em waar de grens bereikt wordt van technisch vernuft en toepasbaarheid van medisch-technische mogelijkheden.

14. Meer dan de helft van alle kunstnierpatiënten (55\%) vindt, dat hun leven door de kunstnierbehandeling ingrijpend veranderd is. Slechts voor $10 \%$ van alle patiënten geldt dit niet of nawelijks. Men dient dit gegeven uiterst serieus te nemen. Wellicht wordt te vaak een ongenuanceerde en te rooskleurige voorstelling wan zaken gegeven via massamedia zoals pers, radio en T.V.-programm's, warin teveel het accent is qelegd op de spektakulaire perspectieven van de kunstrierbehandeling.

15. Bijna 1/3 deel wan de daarvoor in aamerking komende kunstnierpatienten verwacht binnen twee jaar getransplanteerd te worden.

Ruim $2 / 3$ deel wit zich in dit opzicht minder optimistisch, hetgeen begrijpelijk is als men bedenkt, dat de gemiddelde 'wachttijd' momenteel meer dan 21 jaar bedraagt.

16. Overigens is het aantal kunstnierpatiënten dat zeker is van een transplantatie betrekkelijk gering. Binnen het betrekkelijk grote aantal dat niet moer op een transplantatie rekent is de oudere leeftijdsgroep duidelijk over-vertegenwoordigd.

17. De houding t.a.v. een mage lijke transplantatie blijkt tegenstrijdig; $1 / 3$ deel van de Datiënten verwacht hier alles van, $1 / 4$ deel uit zich in deze minter optimistisch. 
18. Van de onderzochte kunstnierpatiënten denkt $80 \%$ er niet of nauwelijks over de eenmal begonnen behandeling te staken. Dat niet alle kunstnierpatienten daar zo over denken stemt overeen met hetgeen onlanas in een onderzoek werd bevestigd n.1., dat dit staken van de behandeling in de praktijk inderdaad, zij het zelden, voorkomt (Loos, e.a., 1979). 
4.5.3. Resultaten van de statistische bewerkingen wan het vragenlijstonderzoek.

4.5.3.1. Op de gegevens betreffende het vragenlijstonderzoek werd een variantieanalyse toegepast. De gegevens werden geprogrammeerd voor de 'break-down'-methode (subprogramna: T.test) een techniek die voorziet in het berekenen van de gemiddelden en varianties van een criterium of afhankelijke variabele voor de verschillende subgroepen van een totale populatie. Tevens werden per item de F-warden en significanties aangegeven (bijlage V1). Om de invloed van onnauwkeurige itembeantwoording op de onderzoeksresultaten uit te sluiten werden per respondent de 'missing values' vastgesteld, wanneer dit aantal boven de $15(10 \%) 1 \mathrm{ag}$ werden de gegevens m.b.t. éen of meer items niet meegenomen. Voor het overzicht van het aantal respondenten warop de gegegevens zijn gebaseerd zie 4.5.2. p. 61 .

Tevens werden chi-kwadraten berekend met betrekking tot de verschillen tussen afhamkelijke en onafhankelijke variabelen.

Tabel 8 geeft een overzicht van het gegeven aantal afhankelijke en onafhankelijke variabelen.

4.5.3.2. Mening over psychische en matschappelijke begeleiding.

Er zijn geen significante verschillen aantoonbaar met betrekking tot de zes onafhankelijke variabelen.

4.5.3.3. Steun van de partner.

Er is een significant verschil tussen het behoren tot een bepalde leeftijdscategorie en de mate van steun en begrip van de partner, in die betekenis 
dat deze steun afneemt bij toename van leeftijd $(P<.05)$.

Het verschil tussen gehwwden en ongehuwden met betrekking tot de mate van steun en begrip van de partner is significant, in die beteken is dat gehuwden meer steun en begrip ervaren dan angehuwden $(P<.001)$.

Het ligt voor de hand deze bevindingen te verklaren uit het feit, dat het begrip "partnerrelatie' met name van toepassing is op de gehuwde patiënten. Toch zij hierbij opgemerkt, dat het niet gehuwd zijn niet altijd betekent, dat men geen partner heeft. Voor hoeveel ongehuwden in de onderzoekspopulatie dit geldt is overigens niet bekend.

\subsubsection{Socjaal isolement.}

Er is een significant verschil tussen gehuwden en ongehuwden met betrekking tot het zich geïsoleerd voelen van vrienden en kennissem, in die betekenis dat gehwwden zich meer geissoleerd voelen $(P<.05)$.

\subsubsection{Insufficiëntiegevoelens.}

Met betrekking tot het zich als patiënt minderwardig voelen maakt de dialyseduur een significant verschil in die betekenis, dat patienten die korter dan een jaar in dialyse zijn meer minderwardigheidsgevoelens ervarem dan patiënten die langer dan 1 jaar in dialyse zijn $(P<.05)$.

\subsubsection{Toekomstwerwachting.}

Er is een significant verschil tussen de onderscheiden opleidingsniveaus met betrekking tot de wijze waarop de toekomst tegenoet wordt gezien, in 
die betekenis, dat patiënten behorend tot de laggst geschoolden (alleen L.0.) de toekamst pessimistischer tegemoet zien dan patiënten met een voortgezette beroeps - of academische opleiding $(P<.001)$.

4.5.3.7. Houding ten aanzien van eventuele dood.

Het verschil tussen dialyseduur met betrekking tot de houding tegenover een eventuele dood is significant, in die betekenis, dat patiënten met een dialyseduur van 1 - 2 jaar en 3 jaar of langer zich minder bang uiten voor de dood dan patiënten met een dialyseduur $<1$ jaar en $2-3$ jaar (P. . . . 5 ).

4.5.3.8. Verandering van leven door de kunstnierbehandeling.

Er zijn geen significante verschillen met betrekking tot de zes onafhankelijke variabelen.

4.5.3.9. Verwachting ten aanzien van een transplantatie.

Tussen doorgangsdialysepatiënten en chronische dialysepatiënten $<50$ jaar en $>50$ jaar bestaat een significant verschil met betrekking tot de trans plantatieverwachtingen, in die betekenis, dat chronische dialysepatiënten $<50$ jaar en $>50$ jaar geen verwachtingen hebben ten aanzien van het getransplanteerd worden $(P<.001)$.

Er is een significant verschil tussen de vier onderscheiden leeftijdscategoriën met betrekking tot de verwachtingen van een transplantatie, in die betekenis, dat patiënten <30 jaar minder verwachten voor een transplantatie in aanmerking te komen dan patiënten tussen 30 - 50 jaar $(\mathrm{P}<.01)$. Een verklaring voor dit gegeven kan zijn - wij baseren dit althans op eigen ervaringen - dat jonge dialysepatiënten, met name diegenen die al enkele 
jaren in dialyse zijn, in de mening verkeerden, dat audere patienten op grond wan hun leeftijd eerder in aanmerking komen voor een niertransplantatie dan de jongeren.

Opmerkelijk is, dat urouwelijke patiênten aanmerkelijk minder hoge verwachtingen hebben t.a.v. een transplantatie.

Het blijft een open vraag of vrowwen in dit opzicht pessimistischer zijn dan mannen of juist realistischer.

Het is in dit verband niet zonder betekenis, dat vrouwen over het algemeen meer dan mannen voorkeur tonen voor continuering van de kunstnierbehandeling boven een transplantatie.

Er bestaat eveneens een significant verschil tussen kortere of langere dialyseduur met betrekking tot de verwachting in aanmerking te komen voor een transplantatie, in die betekenis, dat bij stijging van dialyseduur de verwachtingen afnemen $(P<.01)$.

Significant is ook het verschil tussen gehuwden en ongehuwden met betrekking tot deze variabele, in die betekenis, dat bij gehuwde patiënten deze verwachtingen hoger liggen dan bij ongehuwden $(P, 02)$.

4.5.3.10. Beëindiging van de kunstnierbehandeling.

Er zijn geen significante verschillen met betrekking tot de zes onafhankelijke wariabelen.

\subsubsection{Arbeidssituatie.}

Tensiotte wolgen hier nog enkele gegevens met betrekking tot het geheel, gedeeltelijk of niet meer opgenomen zijn in het arbeidsproces in relatie tot 
de variabelen: - de categorie kunstnierpatiënten (wel en niet transplantabel)

- man/vroww

- opleiding (alleen L.O. versus voortgezette beroeps- en academische opleiding).

Voor de kwantitatieve gegevens met betrekking tot deze relaties en de onderlinge verschillen verwijzen we naar tabel 11.

Uit de gegevens van tabel 10, vr. 8, blijkt, dat slechts $5 \%$ van de respondenten in stad is zich in een volledige werkkring te handhaven, 22 werkt gedeeltelijk en $52 \%$ werkt niet meer (uitkeringssituatie, zie tabe 11). 
Tabel 11. Statistische bewerkingen $\left(x^{2}\right)$ met betrekking tot het al of niet opgenomen zijn in het arbeidsproces.

Transplantabe 1 (A)

Niet transplantabel $(B+C)$

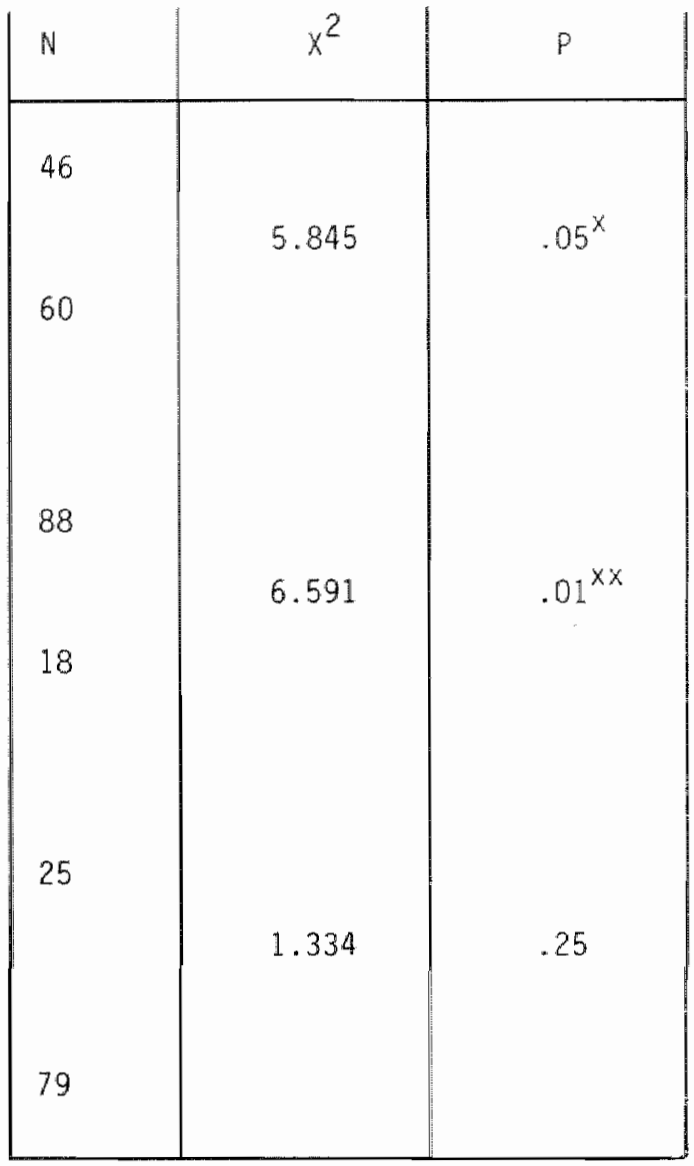

Alleen L.O.

Voortgezette beroeps-
of academische opleiding

Voortgezette beroeps-
of academische opleiding

Mannen

Vrouwen
$\times \quad .05$
$x x .01\left(x^{2}\right.$, correctie voor kleine aantallen) 
De in de tabel 11 vastgelegde aantallen berusten op de gegevens van 135 respondenten (van 5 respondenten waren de gegevens niet bruikbaar). Van de in totaal 43 vrouwelijke patiënten vallen 14 onder een uitkeringsregeling en werken 4 gedeeltelijk buitenshuis. Slechts 3 vrouwelijke patiënten zijn in staat een volledige huishoudelijke taak te vervullen, 22 doen dit gedeeltelijk.

Verondersteld kan worden, dat de 4 mannelijke patiënten die aangaven een gedeeltelijke huishoudelijke taak te verrichten de echtgenoten zijn van de 4 vrouwelijke patiënten die een gedeeltelijke werkkring hebben.

Van de mannelijke patiënten werkt $8 \%$ volledig, $26 \%$ gedeeltelijk en werkt $66 \%$ niet meer.

op de implicaties hiervan wordt teruggekomen in de algemene discussie. Met betrekking tot het hebben van een volledige werkkring is het verschil significant tussen de twee onderscheiden groepen kunstnierpatiënten $(P<.05)$. Waar sprake is van het hebben van een gedeeltelijke baan is er een significant verschil tussen doorgangsdialysepatiënten en chronische dialysepatiëntem $(P<.01)$, in die betekenis, dat doorgangsdialysepatiënten een beduidend grotere kans hebben om een gedeeltelijke werkkring te hebben dan chronische dialysepatiënten.

Gegeven, het niet (meer) opgenomen zijn in het arbeidsproces is er een significant verschil tussen doorgangsdialysepatienten en chronische dialysepatiênten $(P<.05)$, in die betekenis, dat chromische dialysepatiënten de grootste kans hebben niet meer in het arbeidsproces opgenomen te zijn.

Tem aanzien van een volledige werkkring is er geen significant verschil tussen mannen en vrouwen $(P<.20)$. 
In geval van niet (meer) werken is er een significant verschil tussen mannen en vrouwen $(P<.05)$, in die betekenis, dat naar verhouding meer mannen dan wrowwen geen werk meer verrichten. Tegen de achtergrond wan de kwantitutieve gegevens met betrekking tot mannen en vrouwen is dit verschil echter zeer betrekkelijk.

Waar een gedeeltelijk werkkring in het geding is, is er een significant verschil tussen de genoemde opleidingsmiveaus, in die betekenis, dat patienten met een voortgezette- of beroepsopleiding meer kans hebben een gedeeltelijke werkkring te hebben dan patiënten met alleen lager onderwijs $(\mathbb{P}<.05)$. 


\subsubsection{Bespreking der resultaten.}

Zonder te willen stellen, dat de mate van de getoonde ontevredenheid inzake psychische en matschappelijke begeleiding indicatief is voor de psychosociale begeleiding, kan uit de onderzoeksresultaten worden afgeleid, dat oudere kunstnierpatiënten critischer staan ten aanzien van psychosociale begeleiding dan de jongere leeftijdsgroep; dat vrouwen critischer staan ten aanzien van deze begeleiding dan mannen, terwijl ditzelfde geldt voor ongehuwden in vergelijking met gehuwde kunstnierpatiënten.

Deze bevindingen rechtvaardigen de conclusie dat in de praktijk van de begeleiding van kunstnierpatiënten in psychisch en matschappelijk opzicht extra aandacht dient te warden besteed aan de ouderen, de vrouwem en de ongehuwden onder hen.

Ten aanzien van de vraag met betrekking tot de ervaren steun van de partner zijn twee gegevens van belang n.l., dat deze ervaren steun niet afneent bij toename van dialyseduur mar dat er wel sprake is van afnemende steun bij toename van leeftijd, een verklaring voor dit laatste feit is niet zonder meer te geven ofschoon wel kan worden gesteld, dat ook met deze bevindingen rekening dient te worden gehouden bij de begeleiding van deze patiënten en hun partners.

In sociaal opzicht weten vrouwen over het algemeen meer dan mannen hun contacten te handhaven, wellicht weegt de handhaving van deze contacten voor vrouwen zwaarder dan voor mannen, die in dit opzicht kwetsbaarder lijken. Overigens wordt - en dit geldt voor mannen en vrouwen - een toenemend isolement ervaren naarmate men langer dialyseert.

ook de status wan een (hoger) anleidinosniveau lijkt een tegenwicht te bieden 
ten aanzien van het ervaren van insufficiëntiegevoelens. Een algemeen geconstateerd gegeven vindt ook in dit onderzoek bevestiging $n .1$., dat gehuwde patiënten deze insufficiëntiegevoelens vooral beleven ten aanzien van hun levenspartner.

Toekomstperspectief houdt verband met de verwachtingen omtrent een transplantatie.

Uit het feit, dat patiënten >50 jaar zich optimistischer uiten dan patiënten <50 jaar zou kunnen worden afgeleid, dat ten aanzien van de eerste groep ook dankbaarheid blijkt voor het toegevoegde leven en het vooruitzien ook de terugblik impliceert.

Van belang is te constateren, dat het verschil in opleidingsniveau en de daaraan beantwoordende matschappelijke status differentieert ten aanzien van het beleven van toekomstperspectief. Een onderzoekgegeven dat nauw aansluit op eigen klinische ervaringsgegevens bij kunstnierpatiënten is, dat bij toename van dialyseduur men pessimistischer wordt ten aanzien van de toekonst.

De onderzoekgegevens met betrekking tot de houding tegenover een mogelijke dood geven aanleiding te veronderstellen, dat voor patiënten < 40 jaar de doodsproblematiek, voorzover hier al sprake van is, weinig bewust beleefd wordt, in tegenstelling tot degenen in de leeftijdsperiode $40-50$ jaar. Boven de 50 jaar lijkt er in toenemende mate sprake van een rekening houden met en mogelijk de aanvaarding van de eigen dood. Wij brengen dit gegeven in verband met de dankbaarheid voor een toegevoegd leven dat door oudere kunstnierpatiënten vrij regelmatig tot uitdrukking wordt gebracht. 
Ook mag worden aangenomen dat oudere patiënten door datgene wat ze reeds hebben meegemaakt - ook aan sterfgevallen - met de dood als gegegeven meer vertrouwd zijn geraakt.

Terzake van de gevonden verschillen met betrekking tot de diaiyseduur en de houding ten aanzien van een mogelijke dood ligt niet direct een verklaring voor de hand.

Aannemelijk is wel, dat patiënten die nog kort (1 jaar) in dialyse zijn voor zulkeen ingrijpende verandering in de levenssituatie staan, dat dit gepaard kan gaan met doodsangst.

Een dialyseperiode van 2 - 3 jaar valt samen met de gemiddelde wachttijd voor de transplantatie in Nederland.

Niet onwaarschijnlijk is, dat juist het overschrijden van deze wachttijd gepard gat met verhoogde angstgevoelens.

Weinig verschillen op de diverse variabelen tussen de onderscheiden groepen werden geconstateerd met betrekking tot de vraag naar de mate warin de kunstnierbehandeling het leven veranderd heeft.

Voor patienten uit de hogere opleidingsniveaus lijkt deze verandering ingrijpender dan patiënten met alleen L.0.

Voor de gehuwde patienten die meer dan de ongehuwden aangeven, dat hun leven veranderd is, kan worden verondersteld, dat dit samenhangt met een veranderde rol in de gezinssituatie.

Men mag aannemen, dat gehuwde patiënten ten aanzien van hun levenspartner en kinderen 'verlieservaringen' beleven, zich bewust zijn dat ze ontzien worden, dat taken in thet gezin door anderen wordem overgenomen, kortom, dat 
hun positie meer mariginal wordt, althans als zodanig wordt beleefd.

Er kan geen verband worden aangetoond tussen het overwegen de behandeling te beëindigen en éên der onafhankelijke variabelen.

Het overgrote deel der kunstnierpatiënten geeft er de voorkeur aan onder alje amstandigheden de behandeling te contirueren. Aan de motieven die ten grondslag liggen aan beëindiging van de kunstnierbehandeling werd, wat ons land betreft, onderzoek verricht door Hintzen e.a. (1979). 
Aan de bespreking van deze resultaten dient een belangrijk gegeven te worden toegevoegd.

Wit de statistische bewerkingen van het wragenlijstonderzoek blijkt dat van de onafhankelijke variabelen niet alleen het al of njet in aanmerking komen voor een transplantatie, tot op zekere hoogte discrimineert t.a.v de genoemde belevingsaspecten, maar dat dit ook geldt voor variabelen als leeftijd, geslacht, burgelijke status, opleidingsniveau, dialyseduur en werken.

Het volgende overzicht geeft een samenvatting van de resultaten van deze statistische bewerkingen warbij alleen de significante waarden worden vermeld $(P<.05)$.

Tabel 12.

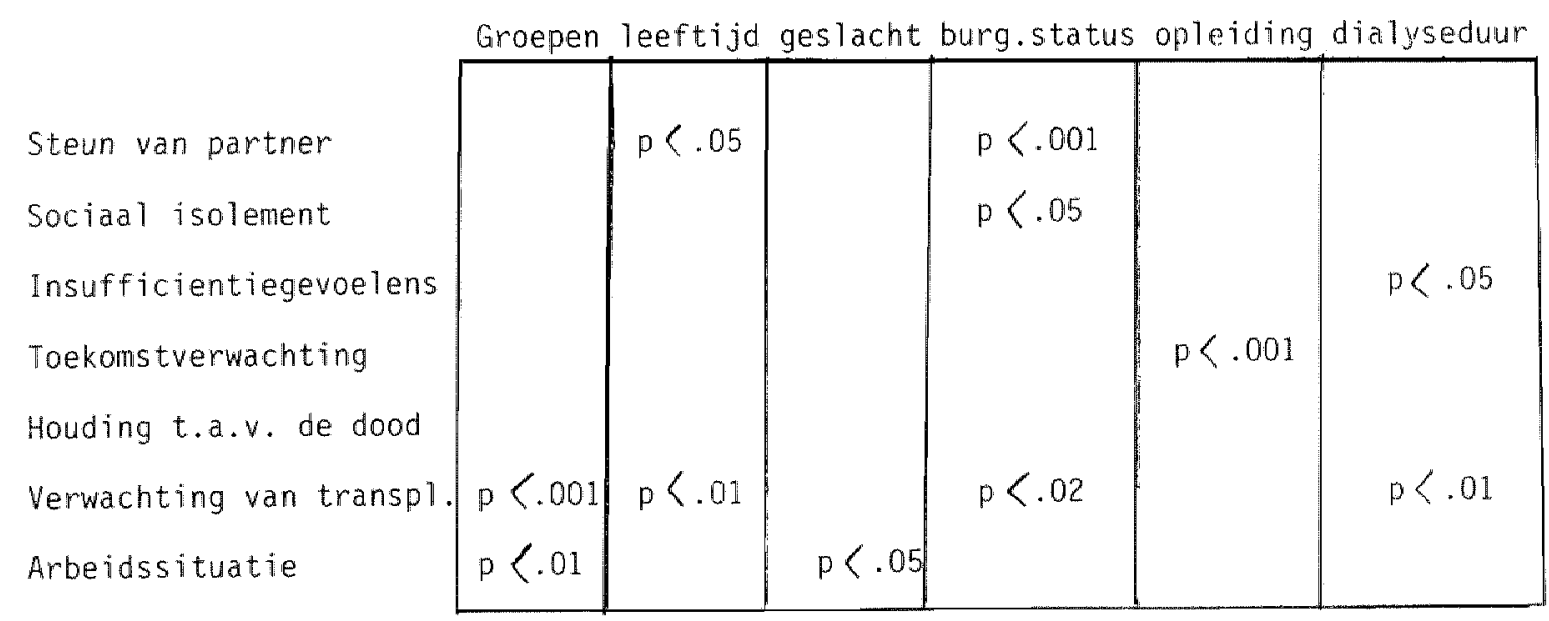


Deze, interessante, gegevens over de arbeidssituatie (4.5.4) en de mate warin de variabele dialyseduur blijkt te differentieren met betrekking tot de afhankelijke variabelen zijn anleiding geweest deze variabelen in het verdere onderzoek te blijwen betrekken en wel op de volgende wijze:

Beide variabelen werden opgesplitst in (a) werken/niet werken en (b) dialyseduur $\langle$ en $>3$ jaar.

Met deze variabelen als uitgangspunt werden enige variantie-analyses toepgepast waarbij beide variabelen werden uitgesplitst woor mannen en vrouwen.

Deze methode werd gevolgd ten aanzien van de afhankelijke variabellen van de vragenlijst ( 9 items), de clusters van de uitsprakenlijst (13) en de begrippen (10) van de semantische differential.

Aan het slat van elk onderzoeksgedeelte worden de resultaten daarvan vermeld. Ter afsluiting van het hoofdstuk worden de alanvillende resultaten meegedeeld die op deze wijze werden verkregen met betrekking tot het vragenlijstonderzoek.

Slechts ten aanzien van twee afhanke 1 ijke variabelen n. 1. transplantatiewerwachting en psychische/matschappelijke begeleiding blijken deze uitgesplitste variabelen significant te differentiëren.

Niet werkende vrouwen, althans zij die zich als zodanig beschouwen, staan significant critischer ten aanzien van psychische en matschappelijke begeleiding dan werkende vrouwen $(P<.05)$.

onder werkende vrouwen worden hier gerekend een (klein) aantal die tot de werkende beroepsbevolking horen en verder diegenen die geheel of gedeeltelijk een huishoudelijke taak verrichten.

Ter verklaring van dit gegeven kan worden aangevoerd dat werkende vrouwen, juist doar hun werk of mobiliteit en de daaraan verbonden socialle setting meer steun en houvast van hun ongeving ondervinden dan de niet werkende vrouwen. 
Wat de variabele transplantatieverwachting betreft blijkt, dat kunstnierpatiënten, mannen zowel als vrouwen, die < 3 jaar dialyseren aantoonbaar meer verwachtingen hebben ten aanzien van een niertransplantatie dan patiënten die $>3$ jaar dialyseren ( $P<.10$ ).

Aldus leidden deze 'uitvergrotingen' vanuit het totalbeeld der onderzoeksresultaten tot een aantal aanvull lende resultaten. 


\subsection{Het onderzoek door middel van de uitsprakenlijst.}

Dit onderzoeksgedeelte kan als voortzetting worden beschouwd van het vooronderzoek.

De witsprakenlijst warvan in het vooronderzoek op basis van face-value dertien clusters werden samengesteld wordt nu in de vorm van een 5 -puntsschal aan de respondenten ter beantwoording voorcelead (Bijlage IV).

Dit onderzoeksgedeelte valt in twee anderdelen witeen. Het eerste onderdeel betreft de toetsing van een vijftal hypothesen (4.6.1.1.t/m 4.6.1.5.) afgeleid uit de conclusies op basis van het vooronderzoek geformuleerd in paragraaf 3.9 .

Deze komen hierop neer, dat de verschillen in de beleving en verwerking van de kunstnierbehandeling vooral betrekking hebben op het groepsonderscheid tussen enerzijds de wel en anderzijds de niet voor een transplantatie in aanmerking komende kunstnierpatiënten, resp. de in het vooronderzoek met $A, B$ en $C$ aangeduide groepen.

Omdat niet a-priori kan worden aangenomen dat de in het vooronderzoek gehanteerde cllusterindeling (op face-value) realiter samenvalt met dimensies van ziektebeleving werd als tweede onderdeel van dit onderzaeksgedeelte een factoranalyse uitgevoerd op de 57 uitspraken van de uitsprakenlijst. Achtereenvolgens zullen hiernavolgend deze beide onderzoeksgedeelten worden beschreven.

4.6.1. De hypothesen.

4.6.1.1. Tem aanzien van de cluster "sociaal isolement" bestaan er aantoonbare verschill en tussen doorgangsdialysepatiënten (groep A) en chronische dialysepatiënten > 50 jaar en $(50$ jaar (de groepen $B$ en $C$ ), in die zin, dat gevoelens van sociaal isolement bij chronische dialysepatiënten meer voor- 
komen dan bij doorgangsdialysepatiënten $(B, C) A)$.

4.6.1.2. Ten aanzien van de cluster "minderwardigheidsgevoelens" bestaan er aantoonbare verschillen tussen doorgangsdialysepatiënten (groep A) en chranische dialysepatiënten $>50$ jaar en $<50$ jaar (de groepen B en C), in die betekenis, dat minderwardigheidsgevoelens bij chronische dialysepatiënten meer voorkomen dan bij doorgangsdialusepatiënten (B, C>A).

4.6.1.3. Ten aanzien van de cluster "aanwaarden van de dood" bestaan er aantoonbare verschillen tussen chronische dialysepatiënten $>50$ jaar en doorgangsdialysepatiënten (groepen B en A) enerzijds, chronische dialysepatiënten< 50 jaar (groep C) anderzijds, in die betekemis, dat gevoelens met betrekking tot het aanvaarden van de dood meer voorkomen bij chronische dialysepatiênten $>50$ jaar dan bij doorgangsdialysepatiënten en chronische dialysepatienten $<50$ jaar $(B>A / C)$.

4.6.1.4. Ten aanzien van de cluster "hoop, vastklampen aan medische mogelijkheden" bestaan er aantoonbare verschillen tussen chronische dialysepatiënten $>50$ jaar (groep B) enerzijds, doorgangsdialysepatiënten en chronische dialysepatiënten (groepen A en C) anderzijds, in die betekenis dat gevoelens van hoop en het zich vastklampen aan medische mogelijkheden minder voorkomen bij chronische dialysepatiënten $>50$ jaar dan bij doorgangsdialysepatiënten en chronische dialiysepatiënten $<50$ jaar $(B<A / C)$.

4.6.1.5. Ten aanzien van de cluster "wanhoop en hopeloosheid" bestaan er aantoonbare verschillen tussen chronische dialysepatiënten $>50$ jaar en $<50$ jaar (groepen $B$ en $C$ ) en doorgangsdialysepatiënten (groep A), in die betekenis, dat gevoelens van wanhoop en hopeloosheid meer voorkomen bij chronische dialysepatiënten dan doorgangsdialysepatiënten $(B / C>A)$. 
4.6.2. De factoranalyse.

Multivariate statistische bewerking biedt de mogelijkheid on een uitwoerige data matrix te reduceren tot een kleinere, in die $z i n$, dat de 57 variabelen van de uitsprakenlijst betreffende evenzovele belevingsaspecten, kunnen worden samengevat in een beperkt aantal ziekte- of belevingsdimensies behorend tot de kunstnierbehandeling.

In deze databewerking qaat het om ziektedimensies met betrekking tot de totale kunstnierpopulatie, warbij derhalve geen onderscheid wordt gemaakt tussen het al of niet transplantabel zijn. De intercorrelaties tussen alle variabelen werden berekend. Om de relevante dimensies te bepalen werd vervolgens een componentenanalyse uitgevoerd ten behoeve van een beschrijving van de originele variabelen in hun onderlinge samenhang.

Tenslotte werd een geroteerde factor matrix samengesteld teneinde de verkregen factoren in hun onderlinge samenhang beter te kunnen interpreteren.

4.6.3. Resultaten van de statistische bewerkingen van het onderzock inzake de uitsprakenlijst.

In deze paragraaf worden de resultaten beschrevem die werden verkregen door een variantieanalyse op de dertien op face-value gevormde clusterindeling. (bijlage VII). Uitgangspunt hierbij is de toetsing van een vijftal geformuleerde hypothesen (4.6.1.1. $t / m$ 4.6.1.5.).

Vervolgens worden de resultaten beschreven van de op de 57 variabelen uitgevoerde factoranalyse (bijlage VIII). 
4.6.3.1. Het ervaren van sociaal isolement.

Er zijn geen significante verschillen aantoonbaar tussen doorgangsdialysepatiënten en chronische dialysepatiënten $>50$ jaar en $<50$ jaar met betrekking tot het ervaren van sociaal isolement $(F .0 .37, P<.70)$.

4.6.3.2. Het ervaren van minderwaardigheidsgevoelens.

Er zijn geen significante verschillen aantoonbaar tussen doorgangsdialysepatiënten en chronische dialysepatiënten $>50$ jaar en $<50$ jaar met betekking tot het ervaren van minderwaardiqheidsgevoelens ( F . 0.63, $P<.55)$.

4.6.3.3. Aanvaarden van de dood.

Hoewel de verschill len tussen chronische dialysepatiënten $>50$ jaar, doorgangsdialysepatiënten enerzijds en chronische dialysepatiënten < 50 jaar anderzijds, met betrekking tat het aanvaarden van de dood niet significant zijn, is er sprake van een trend, in die zin, dat gevoelens met betrekking tot het aanvaarden van de dood meer voorkomen bij chronische dialysepatiënten $>50$ jaar dan bij chronische dialysepatiënten $<50$ jaar en doorgangsdialysepatiënten $(F .2 .51, P<.10)$.

4.6.3.4. Hoop/vastklampen aan medische mogelijkheden.

Er zijn significante verschillen aantoombaar tussen chronische dialysepatiënten $>50$ jaar enerzijds en chronische dialysepatiënten < 50 jaar, doorgangsdialysepatiënten anderzijds, in die zin, dat gevoelens van hoop en zich vastklampen aan medische mogelijkheden minder voorkomen bij chronische dialysepatiënten > 50 jaar dan bij chronische dialysepatiënten < 50 jadr en doorgangsdialysepatiënten (F. $11.90, P<.0001)$. 
4.6.3.5. Wanhoop en hopeloosheid.

Er zijn significante verschillen aantoonbaar tussen chronische dialysepatiẻnten $>50$ jaar en < 50 jar en doorgangsdialysepatiënten met betrekking tot het ervaren van gevoelens van wanhoop en hopeloosheid, in die zin, dat deze gevolens meer voorkomen bij chronische dialysepatiënten dan bij doorgangsdialysepatienten (F. 5.09, P<.01).

4.6.3.6. Resultaten met betrekking tat de afzonderlijke uitspraken (variabelen witsorakenlijst).

De hierboven weergegeven resultaten met betrekking tot het onderzoeksgedeelte over de uitsprakenlijst (zie bijlage VIII), tonen aan, dat de verschillen tussen de drie onschreven categoriën of groepen kunstnierpatiënten (doorgangsdialysepatiënten, chronische dialysepatiënten $>50$ jaar en $<50$ jaar) steun verlenen aan 2 van de 5 dienaangaande geformuleerde hypothesen. Slechts ten aanzien van twee clusters - hoop/vastklampen aan medische mogelijkheden (cluster 10) en wamhoop/hopeloosheidgevoelens (cluster 13) - blijkt er sprake van significante verschillen. Dit betekent dat de aanvankelijke, op de resultaten wan het vooronderzoek gebaseerde veronderste 1 ingen met betrekking tot de verschillen in beleving tussen tenminste twee categoriën kunstnierpatiënten (wel en niet transplantabel) slechts ten dele worden bevestigd.

Om na te gaan welke afzonderlijke uitspraken/variabelen van de clusters wel blijken te differentieren ten aanzien wan het behoren tot een der groepen kunstnierpatiënten werd ook een variantieanalyse toegepast over alle 57 witspraken. Hieruit bleek, dat in 6 van de 13 clusters witspraken voorkomen die significante verschillen aangeven ten aanzien van het behoren tot ëen der onderscheiden groepen kunstnierpatiënten.

Dit geldt, geordend naar cluster, voor de volgende variabelen: 


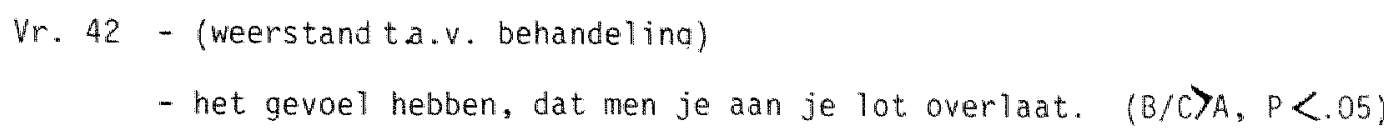

- zeker weten dat je weer de oude wordt

Vr. $36-$ (idem)

- niet aan de toekomst denken

$(A / C>B, P<.001)$

Vr. 24 - (aanvaarden van de dood)

- de dood als mogelijkheid onder ogen zien

$(B>A / C, P<.001)$

Vr. 5 - (hoop/vastklampen aan medische mogelijkheden)

- hopen op een transplantatie

$(\mathrm{A} / \mathrm{O} \mathrm{B}, \mathrm{P}<.0001)$

Vr. 9 - (wanhoop/hopeloosheidsgevoelens)

- geen hoop meer hebben op een transplantatie

$(B / C>A, P<.0001)$ 
4.6.4. Resultaten en bespreking van de variantieanalyse voor de wariabelen werken en dialyseduur.

In paragraf 4.5 .5 werd vermeld dat variabelen als werken/niet werken en dialysedutir vrij opvallend leken te differentieren t.a.v. de uragenlijstitens.

Wij komen daar nu op terug bij de bespreking van de resultaten van het uitsprakenl ijstonderzoek.

Door toepassing van variantieanalyse op de clusterscores van de uitsprakenlijst, warbij dezelfde procedure werd gevolgd die in paragraaf 4.5 .5 is beschreven, kunnen nog enkele aanvullende resultaten worden vermeld aan de hand van de in tabel 13 vastgelegde gegevens.

- Mannen die geen deel (meer) uitmaken van het arbeidsproces ervaren aantoonbaar meer sociaal isolement dan mannen die wel een baan hebben $(P<.10)$.

- Mannen die > 3 jaar dialyseren ervaren aantoonbaar meer sociaal isolement dan mannen die $<3$ jaar dialyseren $(P<.10)$. Ditzelfde geldt voor vrouwen.

- Voor zover sprake is van suîcidale gedachten of wensen komt dit significant meer voor bij niet werkende mannen dan bij mannen die wel deel uitmaken van het arbeidsproces $(P<.05)$.

- Niet werkende vrouwen, althans zij die zich als zodanig beschouwen, ervaren significant meer steun van de echtgenoot dan vrolwen die wel aangeven te werken $(P<.01)$. Het is wan belang mierbij op te merken dat de onschrijuing 'werkende vrouwen' zowel van toepassing is op vrouwen die buitenshuis werkzaam zijn als diegenen die geheel of gedeeltelijk de huishouding verzorgen.

- Mannen die<3 jaar dialyseren geven aantoonbaar meer aan steun te ervaren van de echtgenote dan mannen die $>3$ jaar in dialyse zijn $(P<.10)$.

- Vrouwen die $<3$ jaar dialyseren ervaren significant neer gevoelens van hoop dam vrouwen die $>3$ jaar in dialyse zijn $(P<.05)$. 
- Vrouwen die geen werk verrichten ervaren aantoonbaar neer gevoelens van wanhoop dan vrouwen voor wie het tegendeel geldt $(P<.10)$.

- Angst voor de kunstnier is significant meer van toepassing op niet (meer) werkende vrouwen dan op werkende vrouwen $(P<.05)$.

Uit deze gegevens blijkt, dat in vergelijking met de vragenlijst de uitsprakenlijst naar verhouding meer differentierende mogelijkheden biedt, hetgeen pleit voor de validiteit van dit onderzoeksinstrument. 
TABEL 13. Statistische gegevens ${ }^{x}$ wan twee uitgesplitste variabelen met betrekking tot de uitsprakenlijst (werken, dialyseduur).

\begin{tabular}{|c|c|c|c|c|c|c|}
\hline \multirow[b]{2}{*}{ Clusters } & \multicolumn{3}{|c|}{ Mannen } & \multicolumn{3}{|c|}{ Wrouwen } \\
\hline & werk & $t+w e$ & $t-$ & wer & $t+w e$ & - \\
\hline & of & $\mathbb{P}$ & $\%$ & $\mathscr{B}$ & $P$ & $\%$ \\
\hline Soctial isolement & 12 & $<.10$ & 28 & 16 & $<.10$ & 40 \\
\hline Suicidale gedachten & 10 & $<.05$ & 28 & & & \\
\hline Steun van partner & & & & 20 & $<.01$ & 62 \\
\hline Wanhoop & & & & 24 & $<.10$ & 42 \\
\hline Angst voor kunstnier & & & & 14 & $<.05$ & 26 \\
\hline
\end{tabular}

$x$ opgenomen $\mathrm{P}$ warden $<.10$

\begin{tabular}{|c|c|c|c|c|c|c|}
\hline & \multicolumn{3}{|c|}{$\begin{array}{l}\text { Mannen } \\
\text { dialysedur }<\text { en }>3 \text { jr }\end{array}$} & \multicolumn{3}{|c|}{$\begin{array}{l}\text { Vrouwen } \\
\text { dialyseduur }\langle\text { en }>3 j \text { jr }\end{array}$} \\
\hline & $\%$ & P & $\%$ & $\%$ & $\mathrm{P}$ & $\%$ \\
\hline Social isolement & 12 & $<.10$ & 32 & 10 & $<.10$ & 28 \\
\hline Steun van partner & 24 & $<.10$ & 40 & & & \\
\hline Hoop & & & & 52 & $<.05$ & 20 \\
\hline
\end{tabular}

$x$ opgenomen $P$ waarden $<.10$ 


\subsubsection{Resuitaten en bespreking van factoranallyse op de uitsprakenlijst.}

Door toepassing van de factoranalyse op de 57 variabelen (uitspraken) wan de uitsprakenlijst die betrekking hebben op de belevingsaspecten van de kunstnierbehandeling werdem zeventien lineaire combinaties van variabelen gevornd op basis van intercorrelatie van alle clusterscores (Pearson corr. matrix). Na varimax rotatie waarbij m.b.t. de correlaties $>.35$ als grens werd aangehouden ontstonden negen orthogenale factoren (Bijlage IX).

Deze diverse factoren blijken, in volgorde van de daarop hoog geladen uitspraken, a1s volgt getypeerd:

op factor I, voor $38,4 \%$ bijdragend in de variantie, hebben achttien variabelen een lading $>.35$.

Uitspraak. Lading.

Je minderwaardig voelen (48) .88

Je zelfrespect verliezen (32) .74

Er geen gat meer inzien (51)

Door verlies van werk door ziekte je collega's niet meer zien (23).66 Vaker wensen, dat het maar afgelopen was (33) .64

Je door iedereen verlaten voelen (43) .62

Je wanhopig voelen door alles wat je hebt verloren (4)

Jezelf waardeloos vinden ondat je niets meer kunt (29) .59

Bang zijn voor de kunstnier (47)

Je toekomst als hopeloos ervaren (37) .58

Het gevoel hebben, dat mensen je mijden, niet meer bezoeken (44) .57

Met tegenzin steeds weer naar het ziekenhuis gaan (17) 53

Ervaren dat je rol is uitgespeeld of overgenomen door anderen 
Uitspraak. Lading

Er over denken te stoppen met spoelen (3) .51

Veel last hebben van depressies (25) .49

Bang zijn om uit te gaan, door ziekte aan huis gebonden (40) .48

Er serieus over hebben aedacht on de behandeling te staken (14)

door niet meer naar het ziekenhuis te gaan (14)

Geen behoefte meer hebben om uit te gaan (34)

Deze uitspraken betreffende factor I geven weer hoe men zich insufficiënt, hopeloos en hulpeloos voelt (gevoelens wan hopeloosheid, sociaal isolement, er geen gat meer inzien en ook wel overwegen er mee op te houden). In deze uitspraken klinkt een depressieve ondertoon door. Opvallend is de overeenkomst van deze factor I met het door Engel G.C. (1968) beschreven 'giving-up-given-up complex', bedoeld als een $k$ linische typering van een psychische toestand voorafgaande aan het manifest worden van een ziekte en door hem gekarakteriseerd door de volgende componenten:

- er niet meer tegenop kunnen,

- zich incompetent voelen,

- onzekerheid, het gevoel door de omqeving te worden afgewezen,

- onbeantwoorde verwachtingen,

- beleefde discontinuiteit ten aanzien van verleden - heden - toekomst, geen vertrouwen of hoop meer hebben ten aanzien van de toekomst,

- frustrerende ervaringen die zwaar wegen.

Dit syndroom, aldus Engel, resulteert uit het onvermogen om adequat te reageren op externe stimuli en makt duidelijk hoe een impasse wordt beleefd. Al met al is factor I te typeren als: verlies van gevoel van eigenwarde en toekorstperspectief. 
Op factor II warvan de bijdrage in de variantie $16,2 \%$ bedragat hebben vier variabelen een lading $>.35$.

Uitspraak

Lading

Onder alle omstandigheden willen dat de behandeling

wordt voortgezet (31)

Nietwillen dat de behandeling wordt gestaakt ondat

het geen zin meer heeft (2)

.66

Tot het uiterste toe willen blijuen spoelen en leven ( 3 ) .65

Hopen op een toegevoegd leven dankzij de kunstnier ( 4 )

Gegeven deze typerende uitspraken die uitdrukking geven aan het willen blijven leven, hopen en onder alle omstandiaheden door willen qaan met de behandeling, kan factor II worden gekarakteriseerd als het zich vastklampen aan en doorzetten van de behandeling.

op factor III warvan de bijdrage in de variantie $8,6 \%$ bedraagt hebben zes variabelen een lading $>.35$.

Uitspraak Lading.

Waardering hebben voor de arts en het verpleqend

personee1 (6)

$-.69$

Klagen over gebrek aan accuratesse bij de behandeling (10) .56

Kritiek uiten op de behandeling (39) .55

Vinden dat het personeel zijn best doet orn je te helpen (53)

Het qevoel hebben dat de mensen je mijden of links laten

liggen (44)

Vinden dat iedereen probeert het je naar de zin te maken (12) -.38 Deze factor III kan worden omschreven als kritiek hebben op en zich in de steek gelaten woelen door hulpverleners en anderen. 
op factor IV warvan de bijdrage in de variantie $8,3 \%$ bedragt hebben vijf variabelen een lading $>.35$.

Uitspraak

Lading.

Bang zijn voor storingen in de apparatuur (11) .80

Voortcurend in anqst leven dat er iets misgat (41) .71

Steeds angstgevoelens hebben bij aan- en afsluiten (1) .54

Angst voor de kunstnier (47) .50

De kunstnier als bedreigina ervaren (19) .45

Deze factor IV heeft betrekking op gevoelens rondon de kunstnier en kan worden omschreven als angst door en voor de kunstnier.

Op factor $V$ warvan de bijdrage in de variantie $6,1 \%$ bedraagt hebben vier variabelen een lading $>.35$.

Uitspraak. Lading.

Je wamhopig voellen door alles wat je hebt verloren (4) .81 Geen hoop meer hebben op een transplantatie (9) .81

Zeker weten dat je straks weer de oude bent (30)

Niet aan de toekonst denken (36)

Factor $W$ heeft betrekking op gevoelens van wanhoop ten aanzien van verleden en toekomst.

Het lijkt erop dat deze gevoelens ook betrekking hebben op een niertransplantatie.

Deze gevoelens zijn te omschrijuen als de factor 'wamhoop'. 
Op factor VI waarvan de bijdrage in de variantie 5,9 bedraagt hebben vier variabelen een lading $>.35$.

Uitspraak.

De dood als mogelijkheid nooit willen aanvaarden (21)

Nooit bang zijin geweest (56)

Uiting geven aan angstgevoelens (27)

De dood als bedreiging ervaren (52)
Lading.

$-.48$

.46

Deze factor VI omvat de ambivalente gevoelens in verband met de levensverwachtingen en kan worden gekarakteriseerd als de houding ten of:zichte van de dreigende dood.

Op basis van de uitspraken 21 en 56 in deze factor kan worden gesteld, dat aan deze instelling ook verdringinasaspecten eigen zijn.

Op factor VII waarvan de bijdrage in de variantie $3,4 \%$ bedragt hebbem vier variabelen een ladina $>.35$.

Uitspraak.

Lading.

Niet weten wat jé moet beginnen wanneer je man/vrouw niet achter je stond (35)

Uiting geven aan agressiegevoelens (13) .52

Warderen dat je man/vrouw veel voor je overheeft (26)

Veel steun ervaren van je man/vrouw (15) .36

Factor VII omvat de gevolens met betrekking tot de partner te omschrijven als de houding ten opzichte van de partner. 
Op factor WII warvan de bijdrage in de variantie 1,6 bedraat hebben twee variabelen een lading $\ .35$.

Uitspraak.

Lading.

Mijn behoefte aan sexueel contact is niet minder geworden

sinds ik kunstnierpatient ben (50)

Problemen ervaren in het sexuele contact (55)

Factor VIII heeft betrekking op de sexualiteit.

Op factor IX warvan de bijdrage in de variantie $1,2 \%$ bedraagt hebben twee variabelen een lading $>.35$.

Uitspraak. Lading.

Hopen op medische mogeli,ikheden (45) .78

Hopen op een toegevoegd leven dankzij de kunstmier (18) .38

Deze factor IX heeft betrekking op hoop op medische mogelijkheden.

Samenvattend kam worden geconcludeerd dat de 57 variabelen goed differentiëren binnen de 9 factoren.

Slechts drie variabelen (uitspraken) hebben nog ladingen op een andere factor (var. 18, 44 en 47 . Bijlage VIII). 
De uitgevoerde factoranalyse op de resultaten van de uitsprakenlijst bij honderdtwintig kunstnierpatienten leidt tot de volgende factoren:

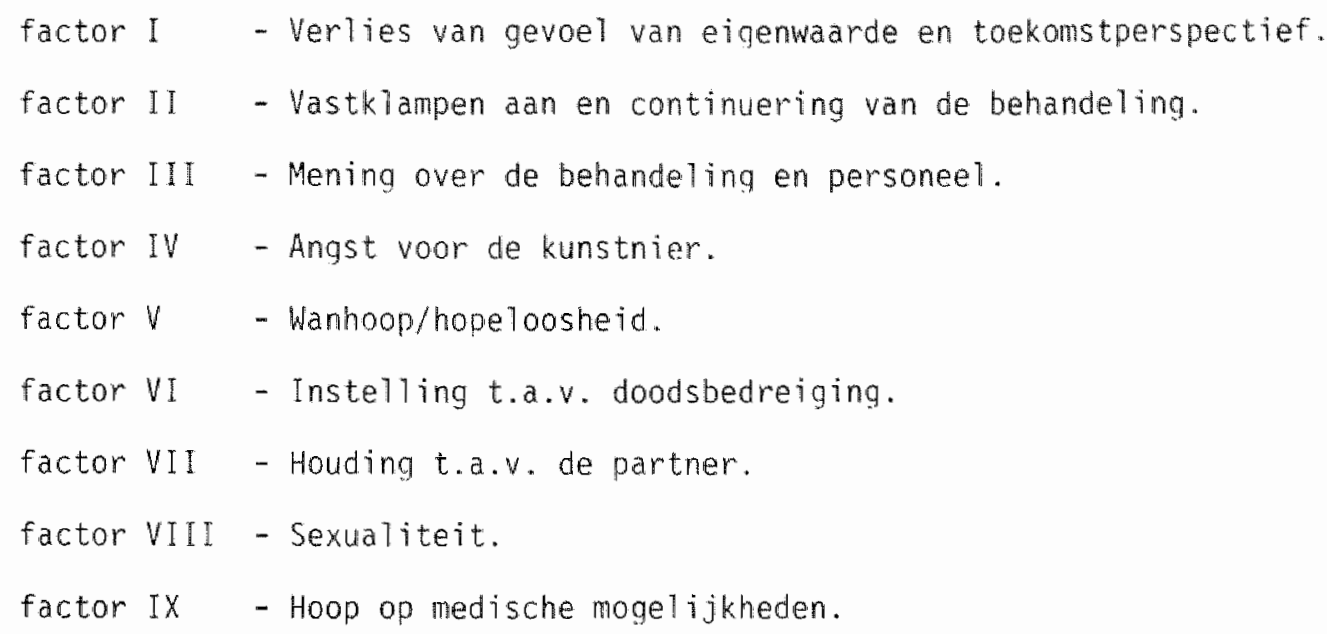

Op deze negen factoren vertonen 48 van de 57 variabelen een hoge lading ().35). De negen niet hoog ladende variabelen zijn de volgende:

- het fijn vinden om hier gespoeld te worden (2)

- je niets aantrekken van voorschriften en regels (7)

- wensen dat men er nooit aan begonnen was (B)

- vinden dat alles goed gat (20)

- hoop hebben dat ondanks je ziekte alles door kan gaan (22)

- je schamen voor je ziekte (28)

- niet aan je ziekte herinnerd willen worden (38)

- regelingen hebben getroffen om op al les voorbereid te zijn (49)

- vinden dat de relatie verbeterd is (57). 
Bij wooronderzoek werden de items van de uitsprakenlijst on face-value ingedeeld in dertien clusters.

Factoranalyse van deze items/uitspraken result teerde in bovengenoende negen factoren.

De uraag rijst nu: hoe verhouden zich de anvankelijk ingeschatte clusters ten opzichte van de factoranalytische bevindingen.

In onderstand schema $z$ in beide weergegeven zoveel mogelijk geordend naar betekenisovereenkonst.

Schenta 2:

Clusterindeling.

Angst voor apparatuur (1)

Positieve mening t.a.v. behandeling (2)

Negatieve mening t.a.v. behandeling (3)

Steun van de partner (4)

Sociaal isolement (5)

Minderwardigheidsgevoelens (6)

Suicidale gedachten of neigingen (12)

Verdringen/ontkennen van de dood (7)

Angst voor de clood (8)

Aanvaarden van de dood (9)

Hoop/vastklampen aan medische mogelijkheden (10)

Continueren van de behandeling (11) Wanhoop/hopeloosheid (13) Indeling op basis van factoranalyse. Angst door en voor de kunstnier (IV) (Kritische) mening t.a.v. behandeling en cersoneel (III).

Houding t.a.v. de partner (VII)

Verlies van eigenwarde en toekonstperspectief (I)

Instelling t.a.v. de dood (VI) Hoop op medische moqelijkheden (IX) behandeling (II)

Wanhoop (V) 
Zonder veel moeite of ombuiging kont uit dit schema de overeenkomst naar voren van acht factoren met dertien clusters.

Van de cluster 'sociad isolement', 'minderwardigheidsqevoelens' en "suicidale gedachten en neigingen" laden vrijwel alle variabelen hoog op factor I, verlies van eigenwarde en toekomstperspectief (zie Bij1. WII). Uit bovenstaande gegevens kan worden geconcludeerd dat de factoranalytische bevindingen een nadere uitzuiverina geven ten aanzien van de op face-value gevormde clusterindeling.

Met de verkregen neaen factorem is een empirische onderbouwing en verheidering verkregen van de "belevingsaspecten" bij kunstnierpatiënten.

Weliswar blijft de onderlinge samenhang van het total der variabelen nog ondoorzichtig.

op basis van de gevonden factoren is een verklaringsmodel van ziektebeleving bij kunstnierpatiënten te ontwerpen met de volgende dimensies, aan te merken als componenten in het psychische krachtveld warin de kunstnierpatiënt zich bevindt:

- wanhoop/hopeloosheid versus hoop (in het algemeen)

- hoop op (nieuwe) medische mogelijkheden versus wanhoop t.a.v. transplantatienogelijkheden in het bijzonder

- positieve versus negatieve mening over de behandeling

- steun van de partner versus het uiting geven an agressiegevoelens

- ontkemmen/verdringen van angstgevoelens versus uiting geven a de deze gevoelens

- contimueren van de behandeling onder alle omstandigheden versus lzij het in geringe mate) het uitina geven aan doodwensen

- verminderde sexuele belevingen versus uiting geven aan deze gevoelens. 
4.7. Yergelijkino van vooronderzoeks- en onderzoeksresultaten met betrekking tot de uitsmakentist.

In 4.6 . werd resteld, dat het onderzoeksgedeel te met betrekking tot de uitsprakenlijst bedoeld was a 15 een toetsingsonderzoek van het op basis van de onderzoekgegevens uit het vooronderzoek gebaseerde operationele model. Vermeld werd dat de verschillen in beleving en verwerking van de kunstnierbehandeling vooral betrekking hebben op het onderscheid tussen wel en niet voor een transplantatie in aamerking komende kunstnierpatiënten. Het is darom wan belang na te gaan in hoeverre de gegevens vanuit het onderzoeksgedeelte m.b.t. de uitsprakenlijst de conclusies uit het vooronderzoek bevestigen.

In 4.6.3.6. werd reeds vermeld, dat de op de resultaten van het vooronderzoek gebaseerde veronderstellingen met betrekking tot de verschillen in beleving tussen wel en niet voor een transplantatie in aanmerking komende kumstnierpatiënten minder witgesproken zijn dan aanvankelijk werd verondersteld. In feite blijkt, dat deze verschillen wel gehandhaafd kunnen worden t.a.v. de cluster 'hoop/vastklampen aan de behandeling' en de cluster 'wanhoop/hopeloosheid'. Hoewel niet significant, mar wel aantoonbar $(P<.10)$ geldt dit verschil ook voor de cluster'aanvarden van de dood'. Uit de onderzoekgegevens met betrekking tot de uitsprakenlijst kan worden geconcludeerd, dat differentiatie tussen de groepen $A, B$ en $C$ (de wel en niet transplantabele kunstnierpatiënten) enerzijds gebaseerd kan worden op basis van clusterindeling (hoop/vastklampen, wanhoop, aanvaarden van de dood), anderzijds gebaseerd is op een aanta? afzonderlijke witspraken binnen de clusters. Dit dwingt ons tot een nadere explicitering en aanvulling van de in paragraaf 3.9. geformuleerde conclusies. 
War gesproken werd over weerstand tegen de behandeling $(p .353 .9$.$) heeft$ dit betrekking op "het qevoel hebben dat men je aan je lot overlat". De in 33.9 . (p.5.) genoende ontkenning en verdedigingsmechan ismen hebben betrekking op: - 'de dood als mogelijkheid ontkennen'

- 'zeker weten dat je weer de oude wordt'

- 'niet aan de toekonst denken'.

Niet voor een transplantatie in aanmerking komende kunstnierpatiënten hebben meer de neiging zich voor hum ziekte te schamen dan transplantabele kunstnierpatiënten.

Waar sprake is van aanvaarden van de dood heeft de differentiatie tussen enerzijds de oudere leeftijdsgroep $>50$ jaar, anderzijds de jongere leeftijdsgroepen $<50$ jaar betrekking op het gegeven 'de dood als mogelijkheid onder ogen zien'. Hoop/vastklampen aan medische mogelijkheder (p.7, 63.9.) heeft betrekking op het gegeven "hopen op een transplantatie" terwijl wanhoop-en hopeloosheidsgevoelens $(p .9,53.9$.$) verwijzen naar het gegeven 'geen hoop meer hebben op een$ transplantatie". 
5. Het onderzoek met de semantische differential.

Osgood publiceerde in 1957 zijn methode wan de semantische differential, ook wel de contrastprofielmethode genoemd, als een instrument waarmee zowel de denotatieve - aanwijzende - betekenis als de connotatieve - meeklinkende - betekenissen wan begrippen kunnen worden gemeten en daarmee onderling vergelijkbaar worden gemakt. Het gaat met name om de neting van deze connotatieve betekenis van begrippen. Hierbij onderkenden 0sqood e.a. (1957) d.m.v. factoranalytische studies drie betekenisdimensies: die van de evaluatie, activiteit en potentie. Deze drie hoofddimensies in de gevoelswaarde van concepten vonden sindsdien steeds weer bevestiging bij een lange reeks van daarop volgende experimenten in de onderzoeks lijnen welke in diverse richtingen met dit instrument werden voortgezet.

Specifiek voor de benaderingswijze van osgood is, dat hij aan de respondent een benald concept voorleqt en dit lat beoordelen met behulp. van een aantal paarsgewijze contrasterende adjectieven b.v. ąroot klein, mooj - lelijk, warm - koud, etc. Deze adjectieven vormen dan de uitersten van een schal. Welke adjectieven men ook kiest, steeds blijken deze grotendeels te divergeren in de drie genoemde fundamentele betekenisdimensies.

Het belang van deze ontdekking ligt in het feit, dat de connotatieve betekeniswereld geen ingewikkelde mar driedimensionele struktuur blijkt te hebben.

Bovendien blijken deze dimensies een universeel karakter te hebben. Osgood vand zijn drie factoren terug in de meest witeenlopende taalgebieden. Voor een meer uitvoerige beschrijuing van de semantische differentialmethode verwijzen we naar Kouwer (1958), Bremer (1972) en Groenman (1978). 
De beide latstgenoende auteurs pasten deze methoden toe bij hum onderzoek van diverse categorieèn patiënten.

Waar zowel de vragenlijst als de uitsprakenlijst, gebruikt in dit onderzoek, betrekking hebben op de belevingsaspecten samenhamgend met of voortvloeiend uit de kunstnierbehandeling, biedt de semantische differential de mogelijkheid van een meer algemeen psychologische oriëntatie ten aanzien van de ziekenhuiswereld.

Bovendien heeft 0sgood's methode het voordeel, dat verschillen binnen de populatie met betrekking tot leeftijd, geslacht, social milieu, etc. vrijwel niet van invloed zijn op de verkregen gegevens. Aan de keuze van de semantische differential als onderzoeksinstrument ligt ook de overweging ten grondslag na te gaan in hoeverre het mogelijk is Osgoods methode toe te passen op een specifieke populatie van patiënten en daamee een dimensionele structuur van belevingsaspecten te ontdekken in de affectieve betekenis van een a antal te beoordelen begrippen.

Voor de toepassing van deze contrastprofielenmethode binnen het onderhavig onderzoek werd een lijst van contrasterende adjectieven samengesteld. Deze werden zo gekozen, dat ze rubriceerbaar waren binnen de drie hoofddimensies. Als uitgangspunt voor het door ons gekozen contrastparenprofiel dienden enkele basispolariteiten uit de door Kouwer (1958) voor Nederland geijkte contrastprofielenlijst. Deze werd aangevuld met contrastprofielen die blijkens de onderzoeken van Bremer (1972) en Groenman (1978) funktioneel bleken voor ziekenhuispatiënten. Met het oog op de belevingswereld van kunstnierpatiënten werd hieraan een aantal specifieke contrasten toegevoegd. De aldus verkregen vijftien contrastparen werden evenredig over de drie betekenisdimensies verdeeld warbij, wat de links-rechts-platsing betreft de adjectiva zo werden geordend, dat zich zowel links als rechts evenveel hoog als laag op die dimensies ladende aanduidingen bevonden. Zo ontstond een definitieve reeks van de volgende contrastparen: goed - slecht zeker - onzeker opstandig - meegaand angstig - opgelucht 


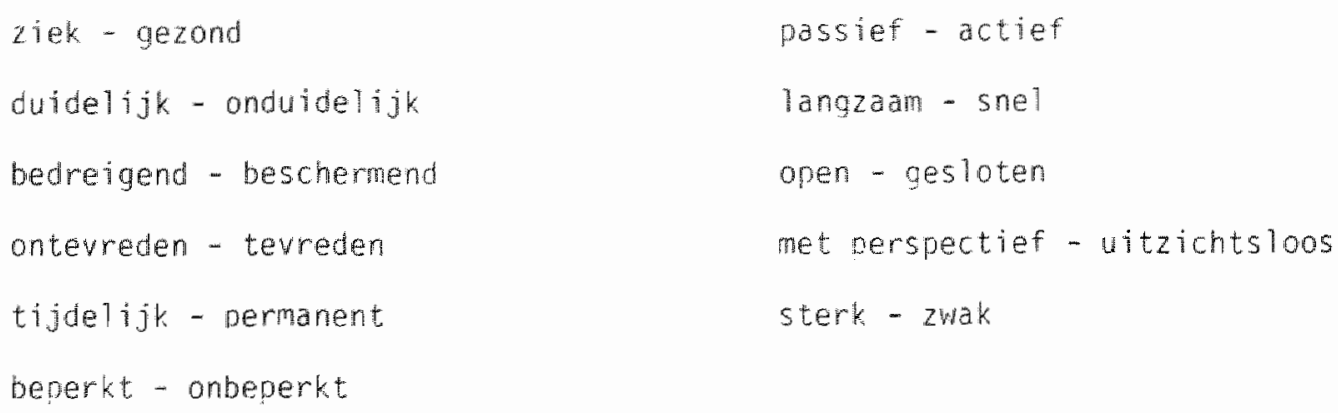

De contrastparen werden on hun face-walue ingedeeld over de drie betekenisdimensies of factoren die in de navolgende tekst zullen worden angeduid als 1. wardedimensie - Factor I

2. intensiteítsdimensie - Factor II

3. activiteitsdimensie - Factor III

Bij deze indeling werd a-priori aangenomen, dat de contrastparen als volgt onder deze factoren rubriceerbaar zijn. (schema 3 ).

$\begin{array}{lll}\text { Factor I. } & \text { Factor II } & \text { Factor III. } \\ \text { beschermend } & \text { sterk } & \text { actief } \\ \text { goed } & \text { gezond } & \text { reëel } \\ \text { duidelijk } & \text { meegaand } & \text { zeker } \\ \text { tevreden } & \text { apgelucht } & \text { permanent } \\ \text { perspectief } & \text { apen } & \text { onbeperkt }\end{array}$

De begrippen of beoordelinasobjecten die tegen deze contrastparen dienden te worden beoordeeld werden conform Bremer (1972) verdeeld naar - instituten

- personen

- situaties

Vanuit dit gegeven werd gezocht naar die instrumentele, persoons-en situationele aanduidingen die representatief konden worden geacht voor de belevingswereld van kunstnierpatiënten. 
Op basis van deze inschatting werd de volgende lijst wan te beoordelen begrippen samengesteld geordend nar instituten, personen en situaties:

Het ziekenhuis

De kunstrierafdeling
De dokter

De verpleegster

Mijn man/vrouw
De kumstnier

Aan het werk blijuen

Dialyseren

Getransplanteerd worden

Ten aanzien van de instituutsbegrippen ziekenhuis en kunstnierafdeling mag worden aangenomen dat deze in de belevingswereld van de kunstnierpatiënt een bijzondere plats innenen.

Hoewel de dialysecentra of kunstnierafdelingen binmen het ziekenhuis een specifieke afdeling vormen war men twee of drie mal per week een aantal (5-7) uren spoelt, kent doorgaans de kunstnierpatiënt het ziekenhuis ook nog van een andere kant.

Immers voor onderzoek, complicaties e.d. wordt de kunstnierpatiënt, afgezien van de dialysedagen ook nog - aemiddeld - 30 dagen opgenomen op de nefrologische of interne afdeling wan het ziekenhuis war men dialyseert. Binnen het $z$ iekenhuis als geheel neent de kunstnierafdeling veelal een specifieke plaats in, deze is dan ook niet qua belevingsaspecten identiek met de doorsneeafdeling van een ziekenhuis (Loos, 1980).

De keuze van de persoonsbegrippen: Dokter en verpleegkundige wordt bepald door de bijzondere plats die deze functionarissen ook als persoon in de behandeling en verzorging bij kunstnierpatiënten inmenen.

Beiden, dokter en verpleegkundige, nemen een meer dan passagère plats in in het leven van de kunstnierpatiënt. 
De dialysebehandeling kan jarenlang duren. Dit betekent een langdurig contact en wederzijdse afhankelijkheid van elkaar, een engagement waardoor de arts-patiênt- en de verpleegkundige-patiënt-relatie op een dialyseafdeling een andere is dan die op doorsneeafdelingen van een ziekenhuis. Dok hier is het derhalve van belang te constateren in hoeverre beide functionarissen een al of niet vergelijkbare positie innemen binnen de belevingswereld van de kunstnierpatiënt.

Het begrip man/vrouw is opgenamen om inzicht te verkrijgen in de betekenis van de partnerrelatie bij kunstnierpatiënten.

Het hebben van een goede relatie blijkt van invloed te zijn op de wijze waarop men de kunstnierbehandeling ondergaat of doorstaat (Loos, 1976, 1978). De steun van het thuisfront is belangrijk, maar er zijn aanwijzingen - ook in ons onderzoek - dat deze relatie niet altijd bestand is tegen de druk van een dergelijke behandelingssituatie.

A1s situaties werd gekozen voor de kunstnier, dialyseren, aan het werk blijven, getransplanteerd worden en sterven.

Shea (1965), Wright (1966) en Abram (1966) wezen op de symbolische betekenis en de symbiotische 'versmelting' van patient en apparatuur bij kunstnierpatiënten "De kunstnier, dat ben ik" (Abram, 1966).

zo kan de kunstnier intermitterend een soort prothese-achtig verlengstuk morden van de patiënt zelf en als zodanig onderdeel zijn van zijn situatie. Het dialyseren stat het meest centrai in de behandelingssituatie enmenmag veronderstellen dat ook in de belevinģswereld van de kunstnierpatiënt het dialyseren als cruciaal behandelingsproces, war zoveel van afhangt, een bijzondere plats inneent. 
Het begrip 'aan het werk blijven' beoogt inzicht te geven in de mogelijkheden on het dialyseren te combineren met werken en de betekeniswa arden van het opgenomen blijuen in het arbeidsgebeuren. Hoewel slechts een beperkt aantal patiënten (50) in dit onderzoek woor een transplantatie in aanmerking komen is de bedoeling van het begrip 'getransplanteerd worden', informatie te verkrijgen over de gevoelswaarde die hieraan wordt toegekend ook door niet transplantabele patiënten.

Sterven tenslotte is het begrip dat verwijst naar een actuele mogelijkheid en naar een persoonlijke inhoud t.a.v. het al of niet aanvaarden van de dood.

5.1. Onderzoeksresultaten met betrekking tot de semantische differentiaal.

Vooropgesteld zij dat de toevoeging van de semantische differentiaal als onderzoeksinstrument hier geen andere pretentie heeft dan na te gaan of en in welke mate dit instrument een bijdrage levert aan het verkrijgen van inzicht in de belevingswereld van kunstnierpatiënten in het algemeen.

We benadrukken daarmee het descriptieve gebruik van deze differentiaalmethode in het onderzoek. Wel zal de betekenis van enkele ingebrachte variabelen aan de hand van de mogelijkheden die deze schaalmethode biedt nader worden getoetst. In paragraaf 5.1.2.1. zullen de resultaten daarvan worden vermeld.

Van de honderdtwintig patiënten aan wie deze schal in zijn definitieve versie werd aangeboden was de invulling bij 23 patiënten te onvolledig om hun scores in de dataverwerking te betrekken. Door 97 kunstnierpatiënten werden witeindelijk 6 begrippen met elk 15 verschillende contrastparen getypeerd. Zo ontstonden 8730 factorscores warover de correlaties werden berekend tussen de contrastparen over de begrippen en proefpersonen.

Daarbij werd de oorspronkelijke opzet van Osgood (1957) glevolgd die ook door Persoon (1975) en Groenman (1978) in hun studie werden toegepast. Omdat het 
niet onmogelijk is, dat bepalde begrippen gekenmerkt worden door specifiek hoge of lage correlaties tussen bepalde contrastparen geeft osgood de voorkeur aan een analyse die berust op de correlaties over alle begrippen boven een anatyse berustend op de correlaties van de afzonderlijke begrippen.

De resultaten van dit onderzoek zijn volgens de beide methoden verwerkt on enerzijas tot een representatieve verdeling te komen van de contrastparen en begrippen over de verschillende factoren, anderzijds on na te gaan in hoeverra de betekeniswaarde van elk afzonderlijk begrip wordt ingekleurd door de indeling der contrastfaren binnen elke factor.

In 5.1. worden de resultaten vermeld van de factoranalyse van de contrastparen over alle respondenten en begrippen.

In 5.1.2. wordt een overzicht gegeven van de factoranalytische bevindingen met betrekking tot afzonderlijke begrippen.

Per factoranalyse werd twee keer volgens de varimaxmethode geroteerd, ëén keer met vier factoren, ëen keer met drie factoren. Ondat bij rotatie met wier factoren de verdeling der contrastparen over de betekenisdimensies meer in overeen stemning was met de a priori indeling, werd besloten de verwerking en interpretatie der gegevens te baseren op rotatie met vier factoren. De uiteindelijke factorladingen daarvan zijn vermeld in Bijlage IX. Alvorens verder te gaan met de beschrijving der resultaten op dit onderzoeksgedeelte een enkel woord aver de door ons op niet voldoende wijze ingeschatte moeilijkheidsgraad met betrekking tot de invulling van de semantische differentiaal bij een populatie van kunstnierpatiënten.

De oorzaak van deze onvolledige invulling bij 40 tot $50 \%$ van de onderzochte populatie kan te wijten zijn aan het feit, dat de semantische differentiaal als laatste onderzoeksinstrument in een reeks van drie werd aangeboden wardoor de motiverende voorwaarden kunnen zijn verminderd.

Een andere verklaring voor de ongeveer $20 \therefore$ niet volledige responsie biedt Kouwer (1958) die stelde, dat de contrastprofielentechniek van osgood niet 
bedoeld zou zijn woor proefpersonen met alleen een lagere school opleiding. dit in tegenstelling tot Bremer (1972) die deze methode pas onbruikbaar acht bij hen die in het algemeen als intellectueel subnormal of abnormal imponeren.

Het is zeker niet ondenkbaar, dat langduriq dialyseren bij bepaalde kunstnierpatiënten leidt tot een zekere mate van verval van intellectuele functies. Zo beschrijven Smith e.a. (1978) in een bijdrage "Diagnosing dialysic dementia": "Dialysic dementia usually offert patients who have been treated by regular heamodialys is for at least one year" (Dialysis and Transplantation, vol. 7, no. 12, pag. 1264), maar het is evenmin ondenkbaar dat hier ook sprake is van iatrogene aandoeningen die als dementieel verval worden geduid. Hoe het ook zij, het is warschijnlijk dat de mate van abstraherend vemogen die bij deze schaalmethode van 0sgood vereist is door een relatief groot aantal kunstrierpatiënten niet wordt opgebracht.

Mogelijk is ook, dat de mate warin men zich affectief heeft kunnen beschermen in de voorgelegde begrippen aan de hand der gekozen contrastparen onvoldoende is geweest.

Dit geldt met name voor begrippen als mijn man/vrouw, aan het werk blijven, getransplanteerd worden en sterven.

Wat het begrip man/vrouw betreft geldt voor de gehuwde patiënten, die in dit opzicht verstek lieten gaan, dat de moeilijkheid was gelegen in het feit, dat hier geen eenduidig $c . q$. enkelvoudig begrip is aangeboden. Voorts rijst hier de vraag of de geboden contrastparen voor personen die zo nabij worden beleefd in de keuze der adjectiva onvoldoende houvast bieden en dat relatief velen er van afzien t.a.w. de huwelijkspartner bij deze gevalgde methode bloot te geven.

Bij het 'getransplanteerd worden' bleek het aantal missing values voornamelijk aanwezig in de categorie niet-voor-transplantatie-in-aanmerking-komende kunstnierpatiënten (de groepen B en C), maar ook bij doorgangsdialysepatiënten lag het aantal niet respondenten in deze boven de aanvaardbare grens van $20 \%$ die voor dit onderzoeksgedeelte werd aangehouden. 
Voor de begrippen 'aan het werk blijven' en 'sterven' geldt - achteraf wat hierboven reeds werd aangeduid, dat men zich er niet voldoende in heeft kunnen herkennen.

Na aldus een verklaring te hebben gegeven voor het niet opnemen wan vier begrippen in de resultatenbeschrijuing wan dit onderzoeksgedeelte wervolgen wij deze beschrijuing.

Van de oorspronkelijke berekende factor $V$ bleken de factorladingen demate laag $(4.30)$ dat deze niet meer dan toevallige verbanden aan kumnen geven. Daarom werd besloten deze vijfde factor bij de verdere bewerking en interpretatie der onderzoeksgegevens te elimineren.

Van de vier factoren die worden vermeld bleek de gemiddelde bijdrage in de variantie resp. $27,21,14$ en $3 \%$.

Over het algemeen bleken van de vier factoren de eerste drie in hun structuur goed overeen te komen met de drie dimensies die bij gebruik van de semantische differentiaal steeds weer worden aangetroffen en als gronddimensies van de 'semantische ruimte' blijken te fungeren.

Uit onderstaand schema blijkt binnen welke betekenisfactoren de verschillende contrastparen kunnen worden ingedeeld, warbij de hoogte der factorladingen maar vooral de frequentie van de hoogste ladingen der contrastparen als criterium voor het onderbrengen van een contrastpaar binnen een bepalde factor geldt 1

Verschillende contrastparen blijken overigens in meer dan één factor een lading te hebben $>.30$ (zie Bijlage IX).

Op basis van cijfermatige gegevens vermeld in de Bijlagen $I X$ en $x$, warin de factoranalytische bewerkingen vermeld staan, werd besloten de contrastparen als volgt ower de betekenisfactoren te verdelen, warbij de onderstreepte adjectiva overeenkomen met de a priori indeling volgens de door osgood aan- 
gegeven grondstructur.

Schema 4 Verdeling van contrastparen over de factoren.

Factor I

sterk - zwak

bedreigend - beschermend

duidelijk - onduidelijk

tevreden - antewreden

perspectief - witzichts loos

Factor II

open - ges laten

goed - slecht

opstandig - meegaand

Factor III

passief - actief

zeker - onzeker

langzaam - snel

angstig - opgelucht

Factor IV

permanent - tijdelijk

beperkt - onbeperkt

ziek - gezond

De gevonden factor IV toont een beeld, dat kan worden omschreven binnen de dinensie van tijdelijk - permanent, beperkte-onbepente gezondneid. 
Het contrastrabr ziek - gezond ladt overigens (zie Bijlage $x$ ) in alle vier factoren mar het hoogst in factor IV.

Van de contrastparen tijdelijk - permanent en beberkt - onbeperkt, oorspronkelijk opgenomen bimen de a priori indeling in factor III geldt, dat ladingen $>.30$ alleen voortomen binnen factor IV en dat op grond van zowel de hoogte als de frequentie der factorladingen binnen factor IV, deze factor dient te worden toegevoegd als een vierde, afzonderlijke betekenis-dimensie. Dat deze factor IV op deze wijze nar voren kont op grond van de genoende contrastparen betekent dat hij weinin samenhang vertoont met de andere polariteiten mar wel differentieert tussen de bearippen.

Kowwer (1961) en Groenman (1978) vermelden dat in deze factor $1 \mathrm{~V}$ de situatie naar voren komt warin de persoon zich bevindt ten tijde van het onderzoek. Bremer (1972) acht de vierde - extra - factor bij onderzoeken volgens Osgood dan ook 'juist typerend' voor de betreffende onderzoekspopulatie. De behandelingssituatie warin de kunstnierpatient zich bevindt wordt specifiek gekleurd op de dimensie van beperkt - onbeperkt, tijdelijk - permanente belleefde of verwachte gezondheid.

Werden in bijlage IX de resultaten van de beschreven factoranalytische bewerkingen vermell op basis van correlatie tussen alle contrast-paren, in bijlage $x$ worden de resultaten vermeld ten anzien van het onderscheid dat weri gemakt tussen instituten, personen en situaties.

Bij de rubricering van een contrastpaar binnen een bepalde factor werd een grens van $>.30$ a angehouden.

op pag. 119 wordt de frequentie aangegeven warmee elk contrastpaar een Tading heeft binnen een der vier factoren.

Bij de opstelling van deze frequentie werd conform Groenman (1973) als criterium gehanteerd dat een contrastpaar ladingen kan hebben binnen meer dan ëẹn factor wanneer deze $<.10$ van ellkar verschillen. 
Zo blijkt (zie bijlage IX), dat de volgende, voor factor I kenmerkende contrastparen ladingen hebben op én of meer andere factoren:

Bedreigend - beschemend heeft ook ladingen op de factoren II en III. intensiteit en activiteit evenals het contrastpaar tevreden - ontevreden, terwijl duidelijk - onduidelijk en perspectief - uitzichtsloos een lading hebben op factor II.

Voor de, primair voor factor II kenmerkende, contrastparen geldt, dat opstandig - meegaand ook ladingen heeft op factor I en III, terwijI open - gesloten ook op factor I een lading heeft. 
Voor de primair voor factor II karakteristieke contrastparen geldt, dat de contrastparen langzaam - snel, angstig - opgelucht, ook ladingen hebben op de factoren 1 en II en actief - passief ook een lading op factor I vertoont.

Van de - toegevoegde - factor IV heeft tenslotte alleen het contrastpaar ziek - gezond ook een lading op meer factoren.

Resumerend blijkt, dat de drie betekenisdimensies à la Osgood zijn terug te vinden binnen de factoranalytische bevindingen van dit onderzoek, zij het met een enigszins andere verdeling van de voor deze factoren meest typerende contrastparen.

In de verdere beschrijuing wan de onderzoeksresultaten richten wij ons met name op de betekeniswaarde der contrastparen binnen de verschillende factoren, in de eerste plaats binnen de onderverdeling van resp. instituuts-, persoonsen situatiebegrippen, daarna ten aanzien van de begrippen afzonderlijk.

In paragraff 5.1.2. wordt voor elk begrip de positie aangegeven die deze binnen een der wier factoren heeft.

Bijlage XI geeft een overzicht van de positie der begrippen binnen de vier betekenisdimensies. Daartoe werden de gemiddelde scores van de respondenten berekend voor de vier begrippen op de respectieve dimensies. 


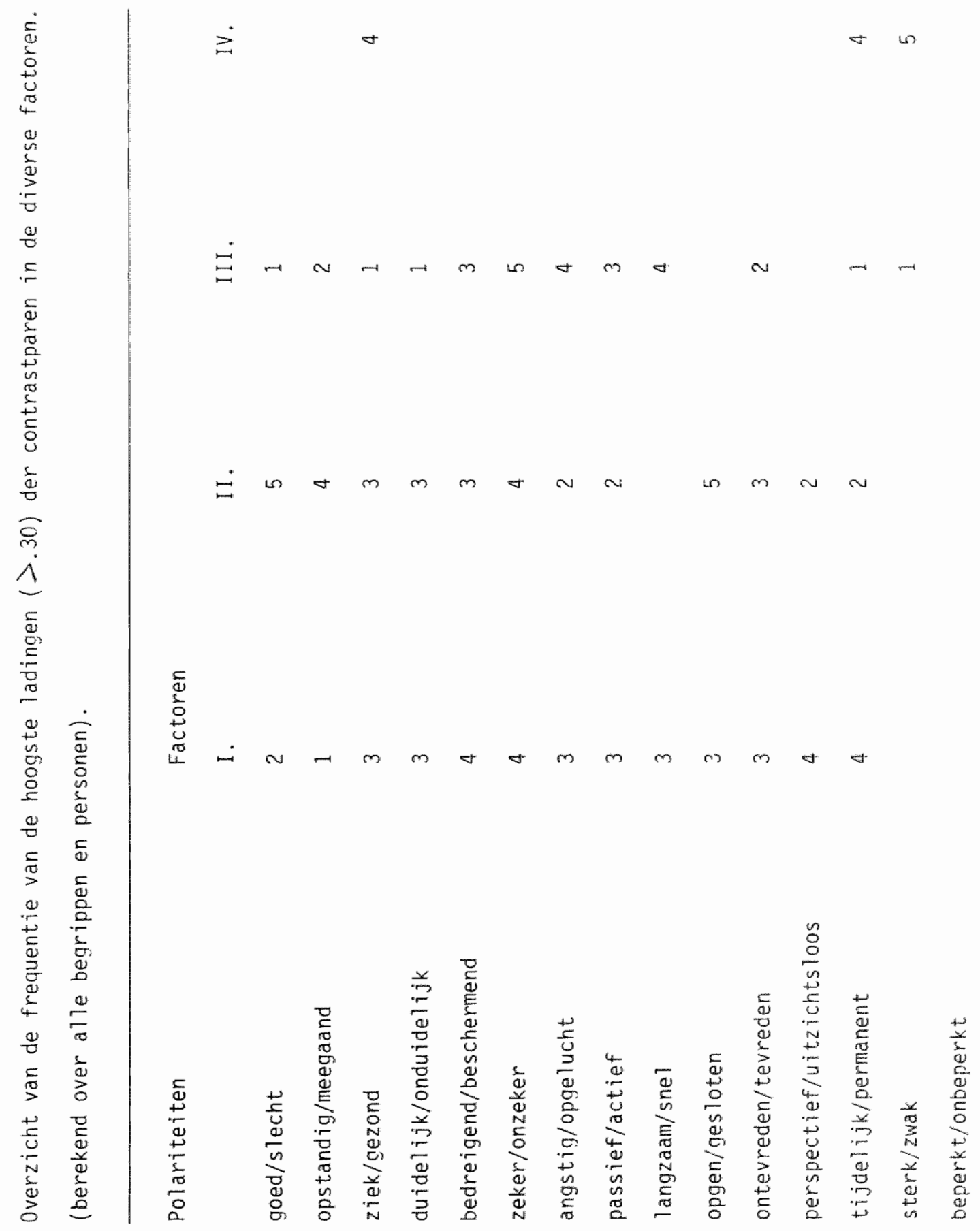


5.1.1. Overzicht en besprekina wan de onderzoeksresultaten betreffende de begrippen / categorieën: instituten, personen en situaties.

Bij vergelijking van de factorladingen der contrastparen over het totaal der begrippen en over instituuts-, personen- en situatiebegrippen (Bijlage $I X$ en $X$ ) valt op, dat zich verschillen voordoen.

Voor ons onderzoek is dit van belang vanwege het inzicht in de belevingswijze van kunstnierpatiënten en het door hen gehanteerde referentiekader ten anzien van deze begrippen.

Bovendien is het niet ondenkbaar, dat kunstniernatiënten (wellicht ook andere catecorieën ziekenhuispatiënten), verschillen met niet-patiënten in betekenisverlening aan deze concepten.

In dit verband kan reeds gewezen worden op de betekenis van de door ons gevonden factor IV waarbinnen het contrast ziek/gezond een belangrijke plaats inneemt.

Voor instituutsbeariopen: ziekenhuis en kunstnierafdeling blijken de door de proefpersonen gekozen richting op de contrastparen van factor I:

sterk/zwak, perspectief/uitzichtsloos, snel/langzaam, actief/passief en zeker/onzeker typerend.

Binnen deze contrastparen geven de kunstnierpatiënten hun waardering of wardeoordeel ten aanzien van deze beorippen.

In dit waardeoordeel ligt de nadruk op de kracht (macht?), de efficiëncy, doeltreffendheid en perspectief biedende elementen die ziekenhuis en kunstnierafdeling voor dialyserende patiënten hebben.

Factor II, de intensiteits - of potentiefactar, geeft relatief hoge ladingen op de contrastparen goed/slecht, zeker/onzeker, duidelijk/onduidelijk, open/gesloten en tevreden/ontevreden.

Van deze contrastparen behoort alleen open/gesloten en meeqaand/opstandig 
tat de oorspronkelijke intensiteitsfactor.

Binnen deze factor II spreekt men zich uit over ziekenhuis en afdeling als open, duidelijkheid en zekerheid biedende instituten.

Voor de contrastparen in de "activiteitssector" komen binnen factor III" geen ladingen $>.30$ voor.

Ziekenhuis en kunstnierafdeling worden binnen deze factor getypeerd vanuit de contrastparen beschermend/bedreigend en meegaand/opstandig.

Factor IV geeft zoals reeds werd vermeld de situatie weer waarin de respondent zich bevindt.

Ziekenhuis en kunstnierafdeling worden hier getypeerd door de contrastparen tijdelijk/permanent en beperkt/onbeperkt, ziek/gezond.

Binnen deze factor IV worden ziekenhuis en kunstnierafdeling beleefd als de instituten die permanente, beperkte/onbeperkte gezondheid bieden. Deze omschrijuing mag als aanvulling en bevestiging worden beschauwd ten aanzien van Bremer"s factor IV, door hem benoemd als nosiciteitsfactor, vooral getypeerd door de termen ziek, passief maar ook, zij het in mindere mate, door sti1, somber en zwak (Bremer, 1972, p.161).

Voor de persoonsbearippen: dokter en verpleegkundige blijken de contrastparen op factor I meegaand/opstandig, bedreigend/beschermend, ziek/gezond, passief/actief, snel/langzaam, angstig/opgelucht, relatief hoge factorladingen te geven (Bijlage $x$ ).

In de betekenisverlening aan hen die het meest direct bij de behandeling zijn betrokken leggen de patiënten/proefpersonen de nadruk op de tolerantie en beschermende houding maar ook op de efficiënte manier van werken. Het $1 \mathrm{jjkt}$ of kunstnierpatiënten zich in hun nabijheid tevreden en opgelucht vaelen.

Factor Il geeft relatief hoge ladingen op de contrastparen open/gesloter, 
duidelijk/onduidelijk, goed/slecht en perspectief/uitzichtsloos.

Binnen deze factor spreekt men zich over de bij de behandeling betrokken personen wit als open, duidelijk en perspectief-biedend.

In factor III - de activiteitsfactor - zijn enkele 'basis'-contrastparen als actief/passief en snel/1angzaam herkenbaar.

In deze factor ligt de doelmatige en efficiënte manier van handelen besloten.

De vierde factor wordt hier getypeerd door de contrastparen beperkt/ onbeperkt en passief/actief.

Deze factor duidt op de dynamiek die van de betrokken personen uitgaat.

Voor de situatiebegrippen: dialyseren en de kunstnier zijn voor factor I de contrastparen passief/actief, open/gesloten, sterk/zwak, ziek/gezond en zeker/onzeker typerend.

De situatie van dialyseren en kunstnier wordt gewaardeerd als een sterke, gezond makende situatie die zekerheid en perspectief biedt.

Op factor II, vooral gekenmerkt door de contrastparen goed/slecht, opstandig/meegaand, tevreden/ontevreden, beschermend/bedreigend ligt in de beleving van de kunstnierpatiënt de madruk op de positieve, tot tevredenheid stemmende, beschermende situatie van het dialyseren.

In factor III, vooral gekenmerkt door de contrastparen langzaam-snel, beschermend-bedreigend, angstig-opgelucht, sterk-zwak, ligt de dynamiek besloten die vanuit het dialyseren wordt ervaren, het dialyseren dankzij de kunstnier als een dynamisch proces.

Factor IV tenslotte wordt hier getypeerd door de contrastparen tijdelijk/ permanent en beperkt/onbeperkt. 
Het is wan belang hier te constateren dat de situatie wan het dialyseren beleefd wordt als een permanent, onbeperkt proces met een onoelimiteerde tijdsduur. 
5.1.2. Overzicht en bespreking van de onderzoeksresultaten met betrekking tot de begrippen afzonderlijk.

In het tweede gedeelte van dit overzicht wan de resultaten van het semantisch differentiaal onderzoek zal de betekenisverlening aan de afzonderlijke begrippen worden geanalyseerd aan de hand van het 4-tal factorbevindingen. Verondersteld mag worden dat de omschrijving van deze factoren overeenkomsten heeft met die van de in 5.1.1. besproken instituuts-, persoons- en situatiebegrippen, toch blijft het mogelijk, dat accenten iets anders komen te liggen.

Achtereenvolgens komen de volgende begrippen aan de orde waarbij achter de cantrastparen de factorladingen $>.30$ vermeld staan.

In onderstaand overzicht zijn alleen dubbele ladingen op andere factoren opgenomen $>.40$.

In dit overzicht zijn die adjectiva van de contrastparen vermeld, die de richting aangeven warin door de proefpersoon is gescoord.

1. Het ziekenhuis.

$\begin{array}{lrlrlrll}\text { factor I } & & \text { factor II } & & \text { factor III } & & \text { factor IV } \\ \text { sterk } & -.71 & \text { duidelijk } & .76 & \text { beschernend } & .74 & \text { permanent } & .67 \\ \text { actief } & .57 & \text { zeker } & .52 & \text { meegaand } & .52 & \text { gezond } & .55 \\ \text { perspectief } & -.55 & \text { goed } & .50 & \text { tevreden } & .42 & \\ \text { snel } & .55 & \text { open } & .49 & & & \\ \text { tevreden } & .45 & & & & & \end{array}$

verk1. war. $36 \%$ 
Kunstnierpatiënten die doorgaans uit veel eigen ervaring met het instituut ziekenhuis bekend zijn, warderen het ziekenhuis positief. Het is warschijnlijk dat zij in dit opzicht niet representatief zijn voor de doorsnee ziekenhuispopulatie, althans wat de mate van deze positieve wardering betreft.

Wellicht speelt hierbij ook een rol, dat de kunstnierpatiënt zich in hoge mate afhankelijk weet van deze instelling.

In dit verband zij ook de suggestie van Bremer (1972) genoend die op basis van de positieve waardering van het ziekenhuis in herinnering roept:

"wiens brood men eet, diens woord men spreekt", een situatie waarin men niet vrij is om weg te gaan (pag. 126).

Binnen factor II wordt het ziekenhuis getypeerd als een oord van duidelijkheid, zekerheid en openheid.

Men zou kunnen zeggen, dat in het licht van deze factor, het ziekenhuis verschijnt als 'de plaats war men weet war men aan toe is".

Factor III duidt vooral op de beschermende, veilige functie van het ziekenhuis, de plats war men zich "thuis' voelt.

Factor IV belicht het ziekenhuis als voortdurend gericht op de gezondheid van de patiënt.

Hierin ligt duidelijk de instelling en verwachting die men ten opzichte van net ziekenhuis heeft. 
2. De kunstnierafdeling.

\begin{tabular}{|c|c|c|c|c|c|c|}
\hline Factor 1 & & Factor II & & Factor ILI & & Factor IV \\
\hline sterk & -.69 & meegaand & -.61 & actief & .70 & onbeperkt \\
\hline perspectief & .33 & goed & .60 & snel & .53 & permanent \\
\hline gezond & .31 & beschermend & -.56 & opgelucht & .43 & gezond \\
\hline & & zeker & .56 & duidelijk & -.36 & \\
\hline & & tevreden & .56 & & & \\
\hline & & open & .45 & & & \\
\hline
\end{tabular}

verkl. var. $34 \%$

In factor 1 wordt de kunstnierafdeling gewardeerd a is het machtige, perspectief- en zekerheidbiedende instrument war men zich opgelucht aan kan overgeven.

In factor II ligt de nadruk meer op de intensiteit van gevoelsmatige aspecten aan de afdeling toegekend, de begrip-en zekerheidbiedende plek war men zich beschermd en tevreden voelt.

In factor III wordt het accent gelegd op de afdeling vanuit de efficiency. het weten war men aan toe is, terwijl in factor IV de afdeling beleefd wordt vanuit de optiek van (on)beperkt biedende gezonaherd.

\section{De dokter.}

Factor I

meegaand .75

open

.77

beschemend . 68

duidelijk

.66

sterk

.56

perspectief .44

$20 \%$

verkl.var. 32
Factor III

tevreden .61

.60

$-.56$

.52

.46

Factor IV

gezond $\quad-.54$

onbeperkt .51

permanent .32 
Factor I benadrukt de arts als de positief gewardeerde figuur die duidelijkheid biedt en bij wie je je vellig kunt voelen.

Binnen deze factor liggen de klassieke betekenis- en waarderingsaspecten besloten die aan de artsenrol worden toegeschreven.

Factor II lijkt een iets sterkere gevoelsmatige lading te hebben vanuit de keuze der contrastparen.

In de verwachtingen en belevingsaspecten naar de arts is hij hier de figuur die open, duidelijk en zeker overkomt.

In factor III wordt de arts sterk getypeerd als de dynamische figuur, die snel, doelgericht en efficiënt werkt.

In factor IV wordt de betekenis van de arts gerelateerd aan het verzorgen en continueren van gezondheid.

4. De verpleging.

\begin{tabular}{|c|c|c|c|c|c|}
\hline Factor I & & Factor II & Factor III & & Factar IV \\
\hline open & -.78 & perspectief .69 & goed & .69 & gezond \\
\hline duidelijk & -.73 & snel & opgelucht & .69 & perspectie \\
\hline goed & -.45 & meegaand & snel & .36 & opge lucht \\
\hline beschermend & .36 & beschermend-. 59 & onbeperkt & .35 & \\
\hline zeker & .34 & actief & & & \\
\hline verk1. var. & $23 \%$ & $21 \%$ & & $16 \%$ & \\
\hline
\end{tabular}

In factor I ligt de wardering ten aanzien van de verpleging besloten in de positief beleefde of verwachte openheid en duidelijkheid en in de be- 
leefde veiligheid.

In de wardering van goed en beschemend ligt een sterke overeenkomst tussen arts en verpleging.

Meega andheid en opluchting worden meer aan de arts toegeschreven dan aan de verpleegkundige, die meer dan de arts gewardeerd worden vanuit de openheid, zekerheid en duidelijkheid.

Factor II typeert de verpleging als efficiënt werkende actieve mensen die je terwille zijn en bij wie je je veilig kunt voelen.

Factor II belicht hen vanuit de beleving van antspanning en doelmatigheid. Deze factor kan onschreven worden als vertrouwen hebben in.

In factor IV wordt de verpleging getypeerd vanuit het perspectief bieden in een situatie van ziekte en gezondheid.

5. Dialyseren.

\begin{tabular}{|c|c|c|c|c|c|c|c|}
\hline Factor I & & Factor II & & Factor III & & Factor IV & \\
\hline actief & .74 & goed & .64 & beschermend & .80 & permanent & $=.80$ \\
\hline sterk & -.63 & meegaand & .57 & zeker & -.61 & onbeperkt & .54 \\
\hline snel & .62 & duidelijk & .52 & opge lucht & .59 & & \\
\hline open & -.59 & & & & & & \\
\hline tevreden & .51 & & & & & & \\
\hline gezond & .47 & & & & & & \\
\hline rspectic & .45 & & & & & & \\
\hline$k 1 . v$ & $36 \%$ & & $13^{5}$ & & 16 & & 6 \\
\hline
\end{tabular}


Binnen factor 1 wordt het dialyseren gewaardeerd als dynamisch efficiënt gebeuren vanuit perspectief biedende gezondheid.

Hier ligt de nadruk op het zakelijk aspect wan de behandeling.

Binnen factor II wordt het dialyseren getypeerd als een positieve veiligheid biedende situatie, als een bescherming en perspectief biedend gebeuren.

Evenals bij de persoonsbegrippen ligt bij factor III het accent op het dialyseren als een situatie die vertrouwen geeft.

Factor IV typeert het dialyseren vanuit de dimensie van een onbeperkt, permanent gebeuren warmee iets zichtbaar wordt van de door de kunstnierpatiënten beleefde continuiteit van het dialyseringsproces.

6. De kunstnier.

\begin{tabular}{|c|c|c|c|c|c|c|c|}
\hline \multicolumn{2}{|l|}{ Factor I } & \multicolumn{2}{|l|}{ Factor II } & \multicolumn{2}{|l|}{ Factor III } & \multicolumn{2}{|l|}{ Factor IV } \\
\hline actief & .66 & beschermend & .63 & snel & .83 & permanent & .73 \\
\hline duidelijk & -.56 & goed & .62 & sterk & -.50 & onbeperkt & .47 \\
\hline sterk & -.56 & tevreden & .56 & gezond & .31 & & \\
\hline open & -.50 & opge lucht & .52 & & & & \\
\hline gezond & .50 & meegaand & .45 & & & & \\
\hline perspect & $f-.42$ & & & & & & \\
\hline verk1. var & $32 \%$ & & $26 \%$ & & $9 \%$ & & \\
\hline
\end{tabular}

Binnen factor I blijkt de waardering voor de kunstnier als die voor een zakelijk en efficiënt gebeuren waaraan kracht, gezondheid en perspectief 
wordt ontleend.

In factor Il worden meer de gevoelsmatige belevingsaspecten aangeduid van de kurstnier als behandelsituatie en instrument vanut de optiek van een bescherming, steun - zekerheid - en vertrouwen gevend gebeuren.

Factor III typeert de kunstnier als een efficiënt beleefde bijdrage ten aanzien van de eigen gezondheid.

Factor IV typeert de kunstmier op overeenkomstige wijze als het dialyseren: de kunstnier die meer permanente en onbeperkte dan beperkte mogelijkheden biedt.

Uit ans onderzoek met betrekking tot de semantische differentiaal is gebleken, dat de affectieve waarde toegekend aan een zestal begrippen kenmerkend voor de kunstnierbehandeling vooral positieve belevingsaspecten betreffen.

In het krachtenveld der belevingsaspecten, dat ligt tussen de uitersten der contrastparen, worden de kunstnierbehandeling, de afdeling en de persanen rondon dit gebeuren sterk positief beleefd, met de nadruk op efficiënt, beschemend, perspectief-en gezondheid-biedend.

Voor zower er binnen dit krachtenveld spanningen zouden zijn, worden deze alleen beleefd ten aanzien van de vraag of de kunstnierbehandeling wel onbeperkte duur garandeert.

Bij vergelijking van de resultaten op de semantische differentiaal, het vragenlijst- en het uitsprakenlijstonderzoek blijkt, dat het beeld voortkomend wit instituuts-, persoons-en situatiebegrippen op de semantische 
differentiaal door de proefpersonen/patienten 'positief'-waarderend wordt 'ingekleurd'.

Uit de vergelijkbare 'items' en contrastparen vam vragenlijst en semantische differentiaal bijjkt een sterke overeenkomst in de wardering van ziekenhuis, behandelinn en personeel (zie hiervoor tabel 10, de items 6 en 13).

Bij vergelijking van semantische differential en witsprakenlijstgegevens blijkt, dat men zich op grond van de uitsprakenlijst enigszins genuanceerder en critischer opstelt ten aanzien van de behandeling als zodanig. Dit betreft dan vooral uitspraken ten aanzien van de apparatuur (kunstnier), de verpleging en het ziekenhuis (met tegenzin er naar toe gaan). Voor de meer inhoudelijke aspecten dezer uitspraken $z i j$ verwezen naar paragraaf $4 \cdot 6 \cdot 3.7$.

Met deze gegevens blijft naar onze mening toch een belangrijke vraag onbeantwoord:

In hoevere is er bij de semantische differentiaal in de connatatieve - "meeklinkende" - betekenis der begrippen sprake van projecties naast de als zodanig beleefide werkelijkheid?

Beoordeelt men het ziekenhuis en de dokter bijwoorbeeld op grand van eigen ervaringen of is de wens hier toch 'vader van de gedachte'? 
5.2 Voortzetting onderzoek met de semantische differentiaal (II).

Zoals dat geldt woor de vragenlijst en uitsprakenlijst zal nu de semantische differential worden benut als toetsingsinstrument met betrekking tot een a antal variabelen waronder werken/niet werken en dialyseduur $\langle$ en $>3$ jaar.

De bedoeling hiervan is na te gaan in hoeverre en in welke richting deze variabelen blijken te differentieren t.a.v. de begrippen/concepten van de semantische differential.

Ondat deze schal tot nu toe slechts in descriptieve betekenis is gehanteerd wordt nu gepoogd de warde van de semantische differentiaal in meer empirische betekenis te onderzoeken.

De tot nu toe beschreven resultaten waren gebaseerd op een steekproef van 97 patiënten warbij zes van de tien oorspronkelijk ingebrachte begrippen werden geanalyseerd.

In dit onderzoeksgedeelte zullen alle tien begrippen worden ingebracht met dien verstande dat de onderzoeksresultaten nu zijn gebaseerd op die proefpersonen die de schalanderdelen (begrippen) volledig hebben ingevuld. Aan deze voorwaarde beantwoordden 81 patienten (spreiding 76 - 84). Achtereenvolgens worden de resultaten besproken vanuit de volgende vraagstellingen:

a. Bestat er verschil in de beleving van een antal entiteiten gemeten door de factoren die blijkens factoranalyse aan die beleving ten grondslag liggen tussen de groepen A, B en $C$ resp. doorgangsdialysepatiënten en chronische dialysepatiënten $\langle$ en $>50$ jaar.

b. In hoeverre en in welke richting differentieren de ingebrachte onafhankelijke variabelen burgerlijke status, dialysedulur en werken t.o.v. de afhanke- 
lijke variabelen (de begrippen van de semantische differentiad).

Ter beantwoording van het eerste uitgangspunt werd een factoranalyse uitgevoerd - met opgave van drie factoren en vervolgens varimax geroteerd. Tevens werd een variantieanalyse uitgevoerd ter beantwoording van de vraag in hoeverre er verschillen zijn aan te tonen op basis van het groepsonderscheid (groepen A, B en C).

De onderzoeksresultaten met betrekking tot het tweede witgangspunt zijn gebaseerd op de via variantieanalyse verkregen gegevens.

In het nu volgende overzicht worden per begrip de factorladingen vermeld >.40. Omdat er in dit geval varimax-rotatie heeft platsgevonden op basis van drie factoren zullen de factoren worden geherformuleerd.

Het Ziekenhuis

Factor 1

$\begin{array}{lclccc}\text { perspectief } & -.68 & \text { gezond } & .66 & \text { onduidelijk } & .72 \\ \text { sterk } & -.62 & \text { permanent } & .55 & \text { onzeker } & .50 \\ \text { actief } & .52 & \text { onbeperkt } & .51 & \\ \text { meegaand } & .48 & \text { snel } & .50 & \\ \text { beschermend } & .45 & \text { zeker } & -.45 & \\ \text { zeker } & -.44 & \text { opgelucht } & .41 & \\ \text { tevreden } & .42 & & & \\ \text { verki. var } & 46 \% & & 11 \% & \end{array}$


De kunstnierafdeling (2)

\begin{tabular}{lcllll} 
Factor 1 & \multicolumn{3}{c}{ Factor 3 } \\
meegaand & .79 & sterk & .76 & uitzichtsloos & .68 \\
goed & .75 & snel & -.73 & permanent & .40 \\
tevreden & -.72 & actief & .70 & & \\
beschermend & .62 & opgelucht & .56 & \\
zeker & -.60 & zeker & .52 & \\
open & .48 & gezond & .44 & \\
opgelucht & .43 & beschermend & .41 & \\
verkl.var. & $38 \%$ & & $24 \%$ &
\end{tabular}

Mijn man/vrouw $(3)$

\begin{tabular}{|c|c|c|c|c|c|c|c|}
\hline Factor 1 & & Factor & & & Factor & 3 & \\
\hline angstig & .71 & goed & & .79 & gezon & & 57 \\
\hline zwak & .70 & besche & Genend & 72 & meega & & 47 \\
\hline onzeker & -.67 & meegaa & & -.55 & tevre & & 43 \\
\hline gesloten &.- .64 & duidel & $j k$ & .47 & & & \\
\hline oriduidelijk & .58 & actief & & .45 & & & \\
\hline witzichts 100 & us .56 & tevred & & .42 & & & \\
\hline verkl.war. & 32 & & & $16 \%$ & & & $7 \%$ \\
\hline De dokter & & & & & & & \\
\hline Factor 1 & & & & Factor 2 & & Factor 3 & \\
\hline meegaand & .72 & duidelijk & .41 & open & .62 & opgelucht & .54 \\
\hline beschermend & -.70 & goed & .41 & smel & .54 & permanent & .42 \\
\hline actief & .64 & & & gezond & -.54 & onbeperkt & .42 \\
\hline onbeperkt & .62 & & & perspectief & $=.52$ & & \\
\hline snel & .54 & & & actief & 41 & & \\
\hline verkl. var. & & & & & 16 & & \\
\hline
\end{tabular}


De Verpleging

\begin{tabular}{|c|c|c|c|c|c|}
\hline Factor 1 & & Factor 2 & & Factor 3 & \\
\hline sterk & .76 & perspectief & .72 & onduidelijk & .48 \\
\hline actief & -.62 & gezond & .56 & gesloten & .42 \\
\hline open & .56 & goed & .48 & srel & .42 \\
\hline duidelijk & .54 & & & & \\
\hline beschermend & -.47 & & & & \\
\hline werkl var. & $26 \%$ & & $12 \%$ & & $8 \%$ \\
\hline De Kunstnier & $(6)$ & & & & \\
\hline Factor 1 & & Factor 2 & & Factor 3 & \\
\hline beschermend & .72 & open & .65 & snel & .61 \\
\hline zeker & -.68 & actief & .62 & uitzichtsloos & -.58 \\
\hline angstig & .62 & snel & .54 & permanent & .49 \\
\hline goed & -.56 & gezond & .47 & & \\
\hline meegaand & .48 & onbeperkt & .42 & & \\
\hline tevreden & .46 & & & & \\
\hline verkl. var. & $41 \%$ & & $16 \%$ & & \\
\hline
\end{tabular}

Getransplanteerd worden (7)

\begin{tabular}{lclcll} 
Factor 1 & \multicolumn{3}{c}{ Factor 3 } \\
goed & .79 & onduidelijk & .70 & onbeperkt & .55 \\
tevreden & .72 & passief & -.61 & sterk & .54 \\
meegaand & .70 & gesloten & .60 & & \\
beschermend & -.69 & zwak & -.56 & \\
zeker & .57 & onzeker & .56 & \\
gezond & .53 & & & \\
verkl.var. & $41 \%$ & & $26 \%$
\end{tabular}


Aar het werk blijwen (oj

\begin{tabular}{|c|c|c|c|c|c|}
\hline Factor" 1 & & Factor & & Factor 3 & \\
\hline duidelijk & -.76 & sterk & .79 & perspectief & -.81 \\
\hline beschermend & .75 & snel & -.79 & tewreden & .72 \\
\hline zeker & .70 & open & -.68 & opgelucht & .54 \\
\hline goed & -.65 & actief & .55 & zeker & .45 \\
\hline gezond & .63 & & & & \\
\hline actief & .50 & & & & \\
\hline opgelucht & .48 & & & & \\
\hline verkl. var. & $38 \%$ & & $22 \%$ & & $8 \%$ \\
\hline
\end{tabular}

Sterven (9)

Factor 1

meegaand

goed

sterk

beschermend

zeker

open

verkl. var.
.70

.70

$-.69$

.65

$-.50$

$-.49$

$26 \%$
Factor 2

actief

perspectief -.65

opgelucht .58

duidelijk $\quad-.45$

snel

zeker

$$
-.42
$$

$18 \%$ tevreden $\quad .48$ .63

Factor 3

onbeperkt

8

20

\section{Dialyseren (10)}

\begin{tabular}{|c|c|c|c|c|c|}
\hline Factor 1 & & Factor 2 & & Factor 3 & \\
\hline actief & .71 & goed & .62 & peminanent & .56 \\
\hline sterk & -.70 & meegaand & .60 & onbeperkt & .48 \\
\hline opgelucht & .62 & tevreden & -.48 & langzaam & .47 \\
\hline snel & .48 & beschermend & .46 & & \\
\hline open & -.42 & & & & \\
\hline verkl . var. & 26 & & $11 \%$ & & $7 \%$ \\
\hline
\end{tabular}


Wij benoemen de factoren aldus:

\section{Ziekenhuis:}

factor 1 . het machtige beschermemde en perspectief biedende institulut - de veilige haven

factor 2. het op onbeperkte en permanent biedende gezondheid gerichte instituut

factor 3. het ziekenhuis als onduidelijk en onzeker makende instituut

Kunstnierafdeling:

factor 1 . de afdeling als "veilige haven"

factor 2. de efficiente en opluchting biedende plek

factor 3 . de afdeling beleefd als eindstation

Mijn man/vrouw:

factor 1. de partner (relatie) beleefd vanuit het onzeker, angstig makende, onduidelijke en uitzichtsloze perspectief

factor 2. de tevreden, goede en bescherming biedende partner

factor 3 . de vanuit tevredenheid en gezondheid beleefde partner

De Dokter:

factor 1 . de dokter als de efficiente, onbeperkt biedende gezondheid, erwaren huilpverlener

factor 2. de dokter gericht op permanent biedende gezondheid

factor 3. de permanent (aanwezige) en optimistische hulpverlener

De Verpleging:

factor 1. de verpleegkundige als toeverladt

factor 2. de verpleegkundige die beleefd wardt vanuit perspectief bie- 
dende gezondheid

factor 3. de verplegkundige als drukdoende "sfinx"

De Kunstmier:

factor 1 . bescherming biedend instrument/apparaat, dat tot tevredenheid stemt maar ook angstig makt

factor 2. de efficiente en solide reddingsboei

factor 3. de apparatuur die het permanente ziek zijn en uitzichtsloosheid accentueert - een corpus alliënum -

Getransplanteerd worden:

factor 1. een niertransplantatie die weldadig is

factor 2. een riskant en mysterieus gebeuren

factor 3. een niertransplantatie die 'het einde' is

Aan het werk blijuen:

factor 1. werken als goed, gezond, actief en bescherming biedend gebeuren

factor 2. werken als sterk makende activiteit

factor 3. werken vanuit perspectief van zekerheid, opluchting en gezondheid

Sterven:

factor 1. sterven als goede dood

factor 2. sterven dat efficient kan gebeuren, wat opluchting biedt

factor 3. positieve aanvarding van de dood

Dialyserem:

factor 1. dialyseren als efficient en opluchting gevend gebeuren

factor 2. geruststellend dialyseren

factor 3 . dialyseren als een gebed zonder eind 
Als aanvulling op de in het descriptieve deel omschreven onderzoeksresultaten kan vanuit bovenstaande gegevens worden gesteld dat het ziekenhuis anbivalent wordt beleefd, het geeft bescherming en gezondheid maar is ook onduidelijk en makt onzeker.

Dezelfde ambivalente gevoelens gelden voor apparatuur (kunstnier) en de verpleging: door de kunstnier word je bescherma mar roept ook angstgevoelens op.

De verpleegkundigen worden als duidelijk, maar ook onduidelijk, open maar ook gesloten ervaren.

Opnerkelijk is ook de wijze warop de partner binnen factor I wordt ervaren vanuit de druk die er op het leven rust door ziekte en behandeling. Vanuit dit onderzoeksgedeelte geven de vier toegevoegde begrippen, vanuit factoranalytische bewerking, belangrijke aanvullende informatie.

op basis van de uitgevoerde variantie- analyse kan met betrekking tot de eerste vraagstelling worden geconcludeerd dat terzake van begrip I, factor 1 , het ziekenhuis, chronische dialysepatiënten $>50$ jaar, het ziekenhuis aantoonbaar meer warderen dan andere dialysepatienten als het machtige en perspectief biedende institut, - de veilige haven - $(P<.10)$.

Ter zake van begrip III, factor 1 , mijn man/urouw geldt, dat chronische diaIysepatienten $>50$ jaar de partner significant meer ervaren vanuit het onzekere, angstige en onduidelijke perspectief dan andere dialysepatiënten $(P<.05)$. Ter zake van begrip VI, factor 2, de kunstnier geldt, dat doorgangsdialyseratiënten de kunstnier significant meer waarderen als efficiente en solide reddingsboei dan chronische dialysepatiënten $(\mathrm{P}<.05)$.

Ter zake van begrip VII, factor 2, getransplanteerd worden geldt, dat chronissche dialysepatiënten $\ 50$ jaar een transplantatie significan' meer ervaren als een riskant en nysterieus gebeuren dan andere dialysepatienten $(P<.05)$. 
Ter zake van begrip $x$, factor 3 , dialyseren geldt, dat doorgangsdialysepatienten het dialyseren significant meer ervaren als een "gebed zonder einde' dan chronische dialysepatiënten $(P<.05)$.

In het nu volgende overzicht worden de resultaten besproken van de tweede vraagstelling met betrekking tot dit onderzoeksdeel: in hoeverre en in welke richting de toegevoegde variabelen werken en dialyseduur differentiëren ten aanzien van een mogelijk aantal afhamkelijke variabelen (de begrippen van de semantische differentiaal).

Hierbij worden de reeds genoemde variabelen uitgesplitst naar mannen en vrouwen. De verkregen resultaten worden besproken aan de hand van de in tabel 14 vastgestelde gegevens ( P warden).

Werkende mannen en vrouwen warderen het ziekenhuis significant meer als het op onbeperkte en permanent biedende gezondheid gerichte instituut - de velige haven - dan niet werkende mannen en vrouwen $(\mathbb{P}<.10,<.05)$.

Niet werkende mannen ervaren de partner significant meer vanuit een onzeker, angstig, onduidelijk en uitzichtsloos perspectief dan werkende mannen $(\mathbb{P}<.10)$. Vrouwen die > 3 jaar dialyseren ervaren de partner significant meer vanuit een onzeker, angstig, onduidelijk en uitzichtsloos perspectief van vrouwen die $<3$ jaar dialyseren $(P<.05)$.

Voor werkende mannen en vrouwen geldt, dat zij een niertransplantatie significant meer ervaren als iets weldadigs dan miet werkende mannen en vrouwen $(P<.05)$. 
Niet werkende mannen waarderen het begrip sterven significant meer in de betekenis wan iets dat efficient kan zijn en opluchting biedt dan werkende mannen ( $p(.10)$.

Mannen en vrouwen die $>3 \mathrm{jr}$. dialyseren warderen het begrip sterven significant meer in de betekenis van rets dat efficrent kan zijn en opluchting biedt dan mannen en wrouwen die $<3 \mathrm{jr}$. dialyseren $(p<.05)$. Werkende mannen waarderen de kunstnierafdeling significant meer in de betekenis van de efficiente en opluchting biedende atideling dan niet werkende mannen $(p<.10)$

Mannen en vrouwen die $\langle 3 j \mathrm{j}$. dialyseren ervaren het aan het werk blijven significant meer in de betekenis van gezond, goed actief en beschermend dan mannen en vrouwen die $>3 \mathrm{jr}$. diallyseren $(\mathrm{p}<.10)$

Mannen en vrouwen die $<3 j$. dialyseren ervaren de kunstnierbehandeling significant meer als een efficient en opluchting gevend gebeuren dan mannen en vrouwen die $>3 \mathrm{jr}$. dialyseren. 


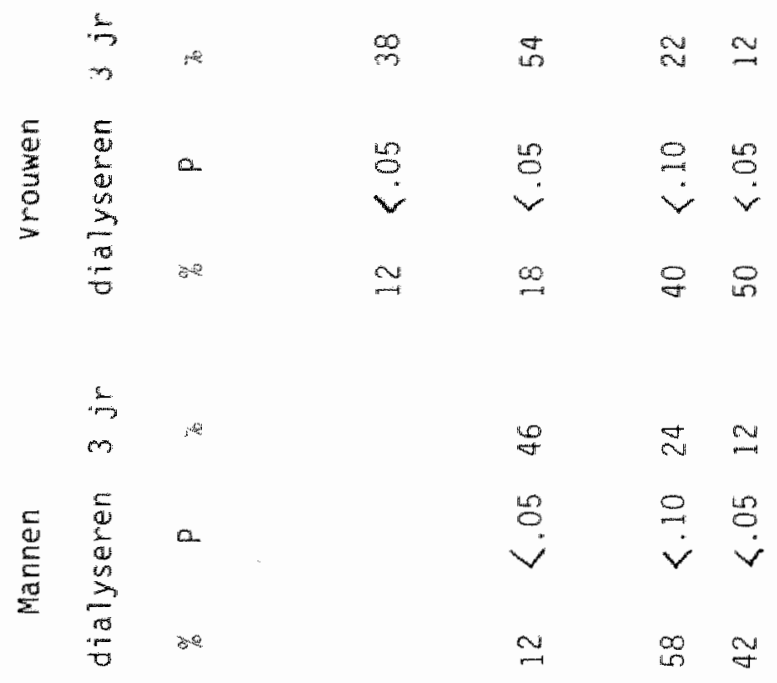

$\frac{5}{\frac{5}{10}}$

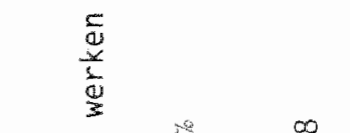

a

$+$

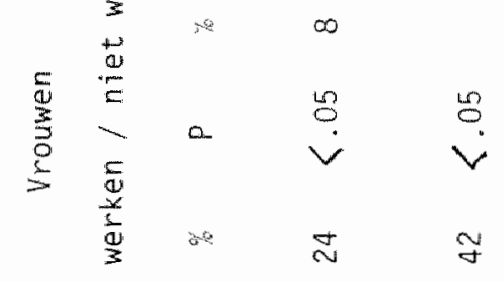

एक

$\prod_{4}^{\infty}$

$\stackrel{5}{v}$

U

至

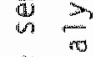

a

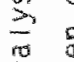

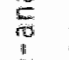

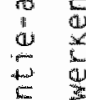

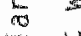

赑

in -

$\stackrel{5}{a}$

$\vec{a}$

g)

$\underset{\square}{+}$

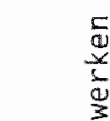

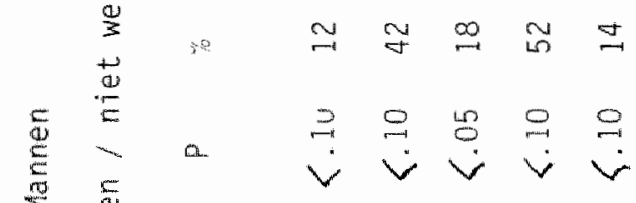

$\frac{5}{3}$

$m \quad 0 \quad 4 \quad 4 \quad 0$

0
0
0
0
0
0

$\sim \rightarrow \rightarrow \infty \rightarrow-$

$\stackrel{5}{8}$

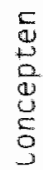

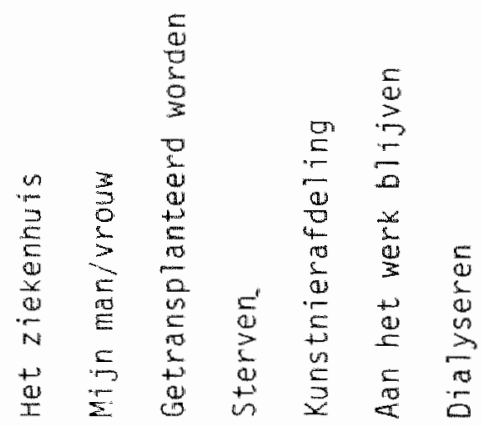


5.7.1. Slotonnerking met betrekking tot de semantische differentiad.

De semantische differentiaal biedt in ons anderzoek informatie over de belevingswereld wan kumstnierpatiënten tegen de achtergrond van instituten, nersonen en situaties, essentieel voor deze behandeling. In het alnemeen kan men zeggen, dat de context, de situering van deze behandeling wat ziekenhuis en afdeling betreft, beleefd wordt a is met macht omgeven, efficiënt en perspectief biedend. Deze glabale betekenisverlening met zijn aan ziekenhuis en afdeling toegekende C.a. daarop geprojecteerde eigenschappen weerspiegelt de afhankelijkheidspositie van kunstnierpatiënten ten aanzien van de betreffende institutem.

Uit de wardering van arts en verpleegkundige blijkt, dat nast de aan deze personen toegekende efficiëncy van handelen juist ook beschermende kwaliteiten worden toegekend.

Hier kont de aard van de vertrouwensmelatie tussen de relevante personen, in casu personeel en patiënten, tot uitdrukking: "De dokter en verpleging staan achter ons en bieden duidelijkheid en openheid", dat is de teneur warin de patiënten/proefpersonen deze relatie weergeven.

Als situatie worden kunstnier en dialyseren als toevluchtsmogelijkheden beleefd, als een effectieve behandel ingsvorm die dan wel permanent kan zijn mar die zekerheid en veilicheid biedt, in de geqeven situatie. Dok hieruit blijkt hoe zeer men zich gebonden weet aan deze, gedwongen maar meer of minder vrijwillig aanvaarde behandelingssituatie. 
Bij vergelijking van de semantische differential, de vragen-en uitsprakenlijst als methode van onderzoek, lijkt de eerstgenoemde in de comotatieve betekenis der begrippen jets meer ruimte te bieden dan meflexieve, voorbewuste aspecten in de belevingswereld dan de meer directe vragen en uitsprakent ijstmethade. Het is dan ook niet onmogelijk dat de resultaten op basis van de semantische differential enigszins zijn "ingekleurd" door verwachtings - en wellicht ook projectieve momenten in de voorstellingsc.q. belevingswereld van kunstnjerpatiënten.

Het ontbreekt ons echter aan voldoende gegevens deze veronderstelling nader te onderbouwer.

Een andere beperking inherent aan dit onderzoeksqedeelte kan zijn, dat er de facto meer dimensies bestaan die van betekenis kunnen zijn bij het gebruik van dit onderzoeksinstrument.

Dit is de beperking waar Kouwer (1958) reeds op doelde waar hij spreekt over het mogelijk effect van eventuele eenzijdigheid in de keuze der begrippen.

Samenvattend menen wij toch, dat de contrast- of polariteitsmethode van Osgood als derde onderzoeksinstrument een waardevolle bijdrage geeft ten anzien van de belevingswereld van kunstnierpatiënten. 
5.3. Vergelijking van de drie onderzoeksinstrumenten: de correlatienatrix.

In deze paragraaf wordt nagegaan in hoeverre en in welk opzicht samenhang bestaat tussen de drie onderzoeksinstrumenten; de afhankelijke variabelen. De te verwachten samenhang heeft vooral betrekking op een aantal items van de vragenlijst en clusters van de uitsprakenlijst die (vrijwel) parallel lopen b.v. vraag 08 en cluster 4 (steun van de partner), vraag 10 en cluster 5 (social isolement), vraag 11 en cluster 6 (minderwardigheidsgevoelens). In bijlage XII wordt deze samenhang weergegeven. Achtereenvolgens komen aan de orde vragenijist en clusterlijst, vragenlijst en semantische differentiaal, clusterlijst en semantische differentiaal.

Uit de gegevens van Bijlage XII kan worden afgeleid, dat de samenhang tussen vragenlijst en clusterlijst kan worden weergegewen in $9 \times 13=117$ correlaties, waarvan 46 sign. $<.05$, de samemhang tussen vragenlijist en semantische differen. tiaal in $10 \times 9=90$ correlaties, warvan 14 sign. $<.05$ en de samenhang tussen clusterlijst en semantische differential in $13 \times 10=130$ correlaties, waarvan 11 sign. $<.05$.

In de hiernavolgende opsamming wordt deze samenhang beschreven.

Angst voor de kunstnier correleert significant met sociaal isolement, minderwardigheidsgevoelens, toekomstverwachting, houding ten aanzien van de dood, verandering van leven en het (willen) beëndigen van de behandeling. Een positieve mening ten aanzien van de behandeling correleert significant met de psychische- en matschappelijke begeleiding. De ervaren weerstand tegen de behandeling correleert significant met sociaal isolement, minderwaardigheidsgevoelens, toekomstwerwachtingen, verandering van leven en het (willen) beëindigen van de behandeling. 
De ervaren steum wan de partner correleert significant met psychische en matschappelijke begeleiding, toekomstverwachting, de houding t.a.v. de dood en verandering van leven.

Het erwaren van sociaal isolement correleert significant met minderwardigheidsgevoelens, toekomstverwachting, verandering van leven en het (willen) beëindigen van de behandeling.

Het ervaren van minderwaraigheidsgevoelens correleert significant met social isolement, toekomstverwachting, houding t.a.v. de dood, verandering van leven en het (willen) beëindigen van de behandeling.

Geen verband kon worden aangetoond tussen de clusters verdringen/ontkennen, angst voor de dood enerzijds en de afhankelijke variabelen (item) van de vragenlijst.

Het aanvaarden van een mogel ijke dood correleert significant met het woornemen de behandeling te (willen) beèindigen.

Het ervaren van gevoelens van hoop correleert significant met steun van de partner en toekomstverwachting.

Het willen continueren van de benandeling -onder alle omstandighedencorreleert significant met toekomstverwachting.

Het ervaren van suicidale gedachten of wensen correleert significant met sociaal isolement, minderwaardioheidsgevoelens, houding t.a.v. de dood en het overwegen de behandelina te beeindigen. 
Het ervaren van gevoelens van wanhoop correleert significant met social isolement, minderwardigheidsgevoelens, houding t.a.v. de dood, verandering van leven, toekomstverwachting en het overwegen de behandeling te beeindigen.

Vergelijking van vragenlijstitems met de begrippen van de semantische differentiaal toont samenhang in enkel opzicht.

De mate warin psychische en matschappelijke beqeleiding wordt gewardeerd of ervaren correleert significant met de wardering van het ziekenhuis als machtig en beschermend instituut en de wardering van de verpleging als open en duidelijk.

De ervaren steun van de partmer correleert significant met de wardering van het ziekenhuis en kunstnieratdeling als machtig en beschermende instituten en de openheid en duidelijkheid van verpleegkundigen.

Het ervaren van sociaal isolement correleert significant met de ervaren onduidelijkheid van verpleegkundigen, de ervaren passiviteit en uitzichtsloosheid t.a.w. een transplantatie, en aan het werk blijwen als sterk makende activiteit.

Het ervaren van minderwaardigheidsgevoelens correleert significant met de wardering van de arts gericht op permanent biedende gezondheid en het dialyseren als langzaam, onbeperkt en permanent proces.

De ervaren toekomstverwachting correleert significant met aan het werk kunnen blijven als gezond, goed en bescherming biedend gebeuren. 
De ervaring dat het leven door de kunstnierbenandeling veranderd is correleert significant met de wardering van de verpleging a is bescherming biedende functionarissen.

De ervaren toekomstverwachting correleert significant met de wardering van de verpleging als bescherming biedende functionarissen.

Vergelijking wan clusters (uitsprakenlijst en begrippen van de semantische differential toont de volgende samenhangende gegevens.

ve wardering wan het ziekenhuis als machtid en beschermend instituut correleert significant met angst voor de kunstnier, steun van de partner, aanvaarden van de dood en hoop.

Het ervaren van de partner (relatie) beleefd vanuit het onzekere, angstig makende, onduidelijke en uitzichtsloze perspectief correleert significant met angst voor de dood.

Le wardering voor de dokter als effnciente en onbeperkt biedende gezondheid erwaren deskundige correleert significant met angst woor de dood.

Getransplanteerd worden als een gebeuren dat zekerheid en gezondheid biedt correleert significant met hoop.

Sterven als iets dat bescherming biedt en goed is correleert significant met het aanvaarden van de dood.

vialyseren als langzaam onbeperkt en permanent ervaren proces correleert significant met wanhoop. 


\subsection{Conclusies}

In psychologisch opzicht kan ten aanzien van de behandelingssituatie van kunstnierpatiënten onderscheid worden gemakt tussen patiënten met en zonder transplantatieperspectief.

In paragraaf 3.9. werd op basis van gegevens uit het vooronderzoek dit onderscheid in verband gebracht met het ervaren bij niet meer voor een transplantatie in aanmerking komende kunstnierpatiënten van sociaal isolement, het ervaren van minderwaardigheidsgevoelens, hoop, vastklampen aan medische mogelijkheden en het ervaren van wamhoop en gevoelens van hopeloosheid.

Wit het hoofdonderzoek blijkt nu dat dit onderscheid alleen gehandhaafd kan worden ten aanzien van het factor-cluster wanhoop/hopeloosheid en hoop/vastklampen aan medische mogelijkheden.

Hierbij kan worden opgemerkt, dat uit de factoranalytische bewerking van de 57 afzonderlijke uitspraken blijkt, dat war sprake is van wanhoop en hopeloosheid deze zich bij niet transplantabele kunstnierpatiënten voora] toespitst op wanhoop niet meer voor een transplantatie in aanmerking te komen.

Voor de hele onderzoekspopulatie van kunstnierpatiënten heeft het factorcluster "hoop" vooral betrekking op het witzicht op een transplantatie en het zich vastklampen aan medische mogelijkheden.

Aangezien de betreffende verschillen in dit opzicht niet significant zijn, maar wel als trend aantoonbaar, ma met enige voorzichtigheid worden geconcludeerd, dat bij niet voor een transplantatie un aanmerking komende kunstnierpatiënten weerstand ten aanzien van de behandeling en het ervaren van minderwaardigheidsgevoelens meer voorkomt dan bij transplantabele kunstnierpatiënten.

Met betrekking tot de factor sexualiteit tonen de factaranalytische degevens, zoals te verwachten is, dat war sprake is van beleefde spanningen 
in de huwelfjksrelatie deze ook samenhang vertonen met de sexualiteitsbelleving.

Gevoelens met betrekking tot het aanvaarden van en angst voor de dood worden gedeeltelijk ontkend.

Men kan stellen, dat er sprake is van ambivalente gevoelens met betrekking tot de - dreigende - dood.

War sprake is van a anvaarding geldt dit vooral voor de niet voor een transplantatie in aanmerking komende oudere leeftijdsgroep.

Het begrip a anvaarden van de dood dient hierbij wel te worden vertaald in de dood als mogel ijkheid onder agen zien.

Minder dan uit ons vooronderzoek blijkt, konden gegevens worden geregistreerd ten aanzien van het ervaren wan suîcidale gedachten of neigingen. Het overgrate deel van kumstnierpatiënten geeft er de voorkeur aan onder alle omstandigheden de behandeling te continueren.

War in het vooronderzoek de hypothese van de grenssituatie werd geverifieerd met betrekking tot het erwaren van sociaal isolement, minderwardigheidsgevoelens, angst voor de dood en wanhoop/hopeloosheidsgevoelens ten aanzien van de jongere, niet meer voor een tmansplantatie in aanmerking konende leeftijdsgroep bevestigen de gegevens uit het onderzoek deze hypothese, uitgezonderd het ervaren van social isolement (het gevael hebben dat men je aan je lot overlaat).

Het gevoel zich in een grenssituatie te bevinden gekenmerkt door gevoelens van wanhoop/hopeloosheid, angst voor de dreiging van de dood, insufficientiegewoelens geldt derhalve met name voor de jongere, niet meer voor een transplantatie in aanmerking komende leeftijdsgroep en voor deqenen, die na éen of meer mislukte transplantaties van mening zijn niet meer voor een transplantatie in aamerking te komen.

De gegevens met betrekking tot de relatie tussen de kunstnierbehandeling en het continueren van de arbeidssituatie tonen aan, dat deze combinatie voor 
$2 / 3$ van de mannelijke kunstnierpatiënten niet meer mogelijk is (66\%).

Dit aantal is hoger dan doorgaans wordt vermeld.

Kunstnierpatiënten die een gedeel telijke werkkring hebben (26\%) be-

horen over het algemeen tot de hogere beroepsniveaus (voortgezette

of beroepsopleiding).

Slechts $8 \%$ van de mannelijke kunstnierpatiënten is in stat de kunstnierbehandeling te cambineren met een valledige werkkring.

De onderzoeksresultaten en de interpretatie daarvan op basis van de op 'face-value' gevonden clusterindeling werden in belangrijke mate bevestigd door de op de uitsprakenlijst uitgevoerde factoranalyse.

Acht van de dertien clusters blijken samen te vallen met evenzovele, dienovereenkomstige, factoren.

Een belangrijk element wit het factoramalytisch onderzoek ligt in de corrigerende betekenis ten aanzien van de clusterindeling.

Zo blijkt, dat het willen beëindigen van de behandeling en het uiting geven aan suîcidale gedachten of neigingen slechts zeer marginal voorkomt bij kunstnierpatiënten.

Van de zevenenvijftig uitspraken van de uitsprakenlijst kunnen er twalf op grond van de geringe ladingen worden uitgesplitst in een definitieve versie van dit onderzoeksinstrument.

De context of entourage war een kunstnierbehandeling is gesitweerd: afdeling, ziekenhuis, arts, verpleegkundigen en het dialyseren zelf wordem sterk positief beleefd.

De onderzoeksresultaten op de semantische differential "kleuren" het beeld, verkregen op grond van de twee overige onderzoeksinstmumenten in versterkende $z$ in.

Vermeld werd reeds dat deze "inkleuring" miet los stad van de aard van dit onderzoeksinstrument. 
Hoewel het onderscheid tussen wel en niet voor een transplantatie in aanmerking komende kunstnierpatiënten voor een aantal belevingsaspecten kon worden gehandhafd dient als een belangrijke conclusie hieraan te worden toegevoegd dat dit onderscheid als discriminerende variabele met name geldt voor belevingsaspecten als hoop, wanhoop, aanvaarden van de dood en toekomstverwachting.

Niet onvermeld mag blijuen dat blijkeris de gegevens van het vragenlijstonderzoeksgedeel te ook andere variabelen zoals leeftijd, geslacht, burgerlijke status, dialysedur en het al of miet opgenomen zijn in het arbeidsproces ook van invloed zijn op de wijze warop de kunstnierpatiënt de behandelingssituatie beleeft.

Bij verder onderzoek naar de belevingswereld van kumstnierpatiënten moet dan ook aandacht worden besteed aan de betekenis van deze variabelen.

De verkregen onderzoeksresultaten dragen bij tot een beter inzicht in de psycholagische betekenis van de kunstnierbehandeling voor wel en niet voor een niertransplantatie in aanmerking konende kunstnierpatiënten. Hiemaan dient als belangrijke conclusie te worden toegevoegd dat, naast het onderscheid tussen wel en niet voor een transplantatie in aanmerking komende kunstnierpatienten, de variabelen wel of niet werken, de lengte van dialysedur <en $>3$ jaar als meest importante discriminerende variabelen kunnen worden beschouwd ter kenschetsing van de belevingswereld van kunstnierpatienten. 


\section{Algemene Discussie.}

6.1. Inleiding.

In dit hoofdstuk worden de voornaamste onderzoeksresultaten betreffende de vragenlijst, de uitsprakenlijst en de semantische differentiaal vergeleken met de hieraan gerelateerde literatuurgegevens, weergegeven in hoofdstuk I p.I e.v.

Uitgangspunt hierbij zijn de op basis van factoranalyse omschreven factoren. Voor de gejeven interpretaties wordt verwezen naar tabel 14 en de Bijlage VI - het vragenlijstonderzoek - en wat het uitsprakenlijstonderzoeksgedeelte betreft de Bijlagen VII en VIII.

Waar de gegevens van het semantische differentiaal onderzoek in deze discussie worden betrokken zij verwezen naar bijlace $I X$ en $X$.

5.2. Vergelijking van onderzoek - en literatuurgegevens.

Wit de onderzoeksgegevens blijkt, dat de factor angst voor de kunstnier niet representatief is voor een bepaalde categorie kunstnierpatiënten. Wit de gespreksverslagen van het vooronderzoek komt naar voren, dat deze angst vooral de momenten van aan- en afsluiten betreft, met name gedurende de eerste dialyseperiode.

Abram (1970) is van mening, dat deze angst een veel grotere rol speelt en van meer dan incidentele aard is. Daarbij dient echter te worden opgemerkt dat hier angst en afhankelijkheid van de kunstnier in feite onder één noemer worden gebracht. De mening van Abram dat er bij veel kunstnierpatiënten sprake is van "symbiotische versmelting" van patiënt en apparatuur, wordt door het onderzoek niet bevestiqd. Dit laatste is in overeenstemming met de bevinding van Wright (1967) waar deze stelt, dat bij zijn patiënten geen 
manifeste angstverschijnselen woorkwamen ten a anzien van het "being hooked up to the machine", zij het dat hij daarbij tevens de mogelijkheid openhoudt dat deze angst kan worden ontkend.

Onze gegevens lopen eveneens vrijwel parallel met de bevindingen van Cramond (1967), dat de angst voor de apparatuur beperkt blijft tot de eerste spoelingen. Hij stelt terecht dat war sprake is van angst deze meer de mogelijke mechanische defecten geldt, dan de apparatur zelf. Kempf (1971) voegt hier aan toe, dat angst voor de apparatuur vooral voorkomt bij extreem afhankelijke mensen. Gegevens die parallel lopen met onze eigen bewindingen zijn tenstotte ook vermeld door Menzies en Stewart (1968) die angst in verband met aan-en afsluiten noemen en Shea en Schreiner (1965) die angst combineren met technische mankementen bij aanen afsluiten.

Concluderend kan wat factor 'angst door en voor de kunstnier' betreft worden gesteld, dat het verschijnsel van de apparatuur als bedreigend ervaren, zeker niet geldt woor de meerderheid van kunstnierpatiënten, maar dat angst voor de apparatuur vooral betrekking heeft op momenten van aan- en afsiuiten en mogelijke storingen in de apparatuur.

Wat betreft de factor "mening ten aanzien van behandeling", biedt de bestaande literatuur, o.a. Kaplan de Nour (1968), Glasman (1970), Diederiks (1974) aanwijzingen dat het zich in deze positief opstellen vooral patiënten met een afhankelijke, conformistische attitude betreft. Uit het onderzoek valt met enige voorzichtigheid te concluderen, dat een positieve houding het duidelijkst naar voren komt bij "doorgangsdialysepatienten" (groep A) en de chronische dialysepatiënten > 50 jr (groep B). Voor de eerste groep geldt, dat hun verwachting, dat de de behandeling van tijdelijke aard is, legitiem lijkt, chronische patiënten blijven van de 
dialyseafdeling en zijn functionarissen afhankelijk.

Uit het onderzoek blijkt, dat een meerderheid van de populatie kunstnierpatiênten zich expliciet in positieve zin wit.

In dit verband is het typerend, dat niet-transplantabele kunstnierpatienten $<50 \mathrm{jr}$ - patiënten die hun perspectief het minst hoopvol beieven het laagst op betreffende factor-items scoren.

De toch wel ambivalente houding van dialysepatiënten ten aanzien van behandeling en personee 1, zoals deze ook uit het onderzoek blijkt, wordt eveneens vermeld bij Kaplan de Nour, Gentry en Davis (1972), die - periodieke - weerstandgevoelens in verband brengen met gedwongen afhankelijkheid en het strenge dialyseregiem wat aanleiding geeft tot agressieve reacties.

Weerstandgevoelens worden in verband gebracht met oncler andere de moeilijk te verdragen afhankelijkheid van ziekenhuis, het dialyseregiem, -diëet en vochtbeperkingen en - meer incidenteel - het gemis aan voldoende begrip, aandacht en accuratesse dat patiënten erwaren bij het personeel. Howel er in de literaturgegevens over deze factor weinig of geen getallen worden genoemd, wordt het verschijnsel als zodanig veelwuldig vemeld. Beard (1969) is wan mening, dat gevoelens en uitinqen van weerstand gerelateerd moeten worden aan perioden van onmacht en moedeloasheid, zich witend in overtreden van diëetrecels, lastig zijn voor personeel en de weinig coöperatieve houding. Cramond e.a. (1967) stellen eveneens dat uitingen van ongenoegens jegens de staf blijken wit het niet accepteren of overtreden van voorschriften. 
Abram (1970), Kaplan de Nour e.a. (1966) noemen emotionele ontladingen en spanningen veroorzaakt door 'stress" die niet bespreekbaar wordt, maar wel blijkt uit periodieke utitbarstingen als reactie op de gedwongen afhankelijkheidssituatie.

Shed en Schreiner (1965) en Menzies en Stewart (1968) stellen, dat de weerstand en kritiek groeiden naarmate de behandeling langer duurt en dat deze weerstand gepaard gaat met het in toenemende mate 'marchanderen' met voorschriften (vooral diëet).

Uht deze gegevens die ook door dit onderzoek bevestigd worden blijkt, dat men dit binnen de bestaande dialyseafdelingen als een reëel verschijnsel dient te beschouwen en dat er van de kant van het personeel veel begrip en tact gevraagd wordt hier op adequate wijze op in te spelen.

Van het belang van een goede relatie met de partner bij kunstnierpatiënten wordt in de dialyseliteratuur veelvuldig melding gemakt. Aan deze factor 'houding ten aanzien van de partner' wordt een belangrijke predictieve waarde toegekend inzake de aanpassing van de kunstnierpatiënt. Dok war selectie- en beoordelingscriteria worden gehanteerd wordt steun van de partner expliciet vermeld (onder andere bij thuisdialysepatienten). De betreffende onderzoeksbevindingen naar deze variabele lopen over het algemeen nogal uiteen.

Het gemiddelde percentage berekend over de gegevens in deze verstrekt door Wright (1966), Friedman (1970), Shambaugh en Kanter (1969) komt op 60\%, d.w.z. iets lager dan de gegevens uit ons onderzoek laten zien. Bij de gehuwde kunstnierpatiënten wordt in ons onderzoek in $74 \%$ van de gevallen melding gemakt van de ervaren steun.

De vergelijking gat overigens niet geheel op omdat in de vermelde onderzoeken ook de gegevens van de partners waren verwerkt, wat in ons onderzoek niet het geval is. 
Wit de gespreksverslagen van het vooronderzoek blijkt, dat mannen frequenter deze steun van hun vrouw ervaren dan ongekeerd en dat deze steun vooral ervaren wordt in het begrip hebben voor de situatie van de patient. het overnemen van 'rollen' in de gezinssituatie en het getoonde begrip voor de verminderde sexuele behoefte en mogelijkheden in de huwelijksrelatie. Enelow en Fried (1967) vonden dat instrumentele (en autoriteits-)rolien werden avergenomen door partners en dat steun vooral ervaren werd in het emotionele vlak.

Wright (1966) stelt, dat de gezinsleden vaak te hoge verwachtingen koesteren en zich over de resultaten van de behandeling vaker teleurgesteld witen dan de patiënten.

Friedman (1970) daarentegen, constateerde bij veertien van de twintig patienten een meer optimistische toekomstverwachting, maar verneldt ook, dat achttien van de twintig patiënten vrij frequent - periodieke - depres sies bij hun partner registreren.

Voor wat de gevalgen van de sexuele relatie betreft, zijn de gegevens over mannelijke en vrouwelijke patiënten niet consistent.

De vrow als partner blijkt meer geinteresseerd in de gezondheid van de echtgenoot dan in de frequentie van het sexuele contact. Van overuragen van de man is in het algemeen geen sprake.

Shambaugh en Kanter (1969) memareren een gegeven, dat overeenkomt met onze bevindingen namelijk, dat de gevoelde afstand tussen partners wordt vergroot, narmate de behandeling langer duurt.

Hoewel de auteurs hier doelen op thuisdialysepatiënten is er weinig reden om aan te nemen dat dit voor centrumdialysepatiënten anders zou zijn. Short, Wilson (1969) wijzen op de belangrijke rol van de echtgenote als partner voor de man welke juist door het prijs moeten geven van die eigenschappen die voor een man van essentieel belang zijn, zijn gevoelens van eigenwarde kan versterken. 
We concluderen hieruit dat;

- Het accepteren wan de dialysesituatie voor de partner op langere termijn warschijnlijk moeilijker wordt (centrum- en thuisdialysepatiënten).

- Ook thuisdialyse wordt, warschijnlijk meer dan verondersteld wordt, door de partner als een belasting ervaren.

- ongehuwde patiénten raken meer geīsoleerd dan gehuwde patiënten. Een soortgelijk isolement wordt overigens ook beleefd doom een aantal gehuwde patiënten.

Onze gegevens over ervaren sociaal isolement - hoewe 1 niet als aparte factor vermeld - lijken in tegenspraak te zijn met wat veelal in de dialyseliteratur wordt beschreven (Kaplan de Nour, 1968, Greenberg, 1973, Coldstein, 1974), die in veel meer dan de helft van de geregistreerde gevallen melding maken van dit gegeven.

Ons onderzoek bevestigt op dit punt meer de conclusies van Harari (1971), Gentry en Davis (1972) die juist een intensivering van sociaal gedrag en contact, zij het na een eerste aanpassings- en verwerkingsperiode, registreren. Een aanvaardbare verklaring hiervoor lijkt dat kunstnierpatiënten zeker tijdens de verwerkingsfase van hum ziekte en behandeling zich terugtrekken van alles wat nieuwe energie en emoties oproept en pas geleidelijk tot intensivering van sociale contacten komen.

Waar bimnen ons onderzoek het saciaal isolement bij de groep niet-meertransplantabele patiëntem < $50 \mathrm{jr}$ sterker wordt beleefd dan bij anderen, wijst dit op een sociaal retireren bij kunstnierpatienten die hun situatie als wanhopig beleven.

Voorzove" er sprake is van verminderde sociale contacten hangt dit hoogstwarschijnlijk samen met het door fysieke beperkingen verminderde uitgaanslever, noeheidsklachten (met name na de spoelingsuren). 
Wright (1966) registreert uitdrukkelijk bij zijn patienten nast andere 'verlies'ervaringen ook het verlies van sociale contacten.

Bij enkele patiënten van wat oudere leeftijd, registreerden wij verlieservaringen, die doen denken aan soortgelijke ervaringen bij rowwreacties. De conclusie, wit eigen onderzoeksgegevens en klinische bevindingen is, dat de kunstnierbehandeling op zichzelf sociale contacten wel enigszins beperkt. maar geen sociaal isolement hoeft in te houden. Een periode van sociad isolement lijkt voor te komen in de periode van verlies en verwerking (bijvoorbeeld het eerste half jaar), warop in de meeste gevallen een zekere aanvaarding van de situatie volgt - de "long term adaptation" (Reichsman en Levy, 1972), gepaard gaande met een herstel van sociale relaties.

Verilies van eigenwaarde en toekomstperspectief worden vaak geassocieerd met patiënten in een chronische afhankelijkheidssituatie.

In de psychosociale dialyseliteratur worden deze gevoelens meer 'en passant' dan expliciet vermeld onder andere bij Wright e.a. (1966) en Lazarus (1969).

De vrij hoge frequentie van uitspraken in deze richting door dialysepatiënten gegeven waren aanleiding on deze factor toch expliciet te categoriseren. Deze factor heeft met mame betrekking op gevoelens van onvolwardigheid in verband met het functioneren in de gezins-en werksituatie. Ook de onvolwaardigheid als sexuele partner in huwelijksrelatie of daarbuiten wordt dikwijls vermeld. Lazarus (1969) en Kessel (z.j.) geven als gevolgen van de behandeling en chronische ziektesituatie aan: aantasting van gevoelens vam eigenwarde, gebrek aan zelfvertrouwen en egoverlies. Het gevoe? door deze ziekte gestraft te zijn en een last voor anderen te zijn bekrachtigt deze insufficiëntiegevoelens.

Bezien we de resultaten van ons onderzoek in dit opzicht, dan blijkt, dat 
deze factor sterk differentieert ten aamien van de verschillende groepen. Minderwardigheidsgevoelens als gevolg van ziekte en/of behandeling werden bij doorgangsdialysepatiënten niet geregistreerd, wel bij patiënten warvan de situatie het meest uitzichtsloos is of als zodanig wordt beleefd. De conclusie lijkt dan ook gerechtwaardigd, dat insufficiëntiegevoelens bij kunstnierpatiënten in het algeneen betrekkelijk weinig voorkomen, wel darentegen bij patiënten die geen transplantatieperspectief hebben of menen te nebben.

Zonder dat hier sprake is van een omschreven factor willen wij toch een enkele opmerking maken over het voorkomen en de frequentie van ontkenningsen verdringingsverschijnselen, in het algemeen als afweermechanismen aangeduid; hierover zijn de onderzoeksresultaten, vermeld in de literatuur, averigens al leminst eens]uidend.

Wright e.a. (1967) stelden - onder andere op basis van M.M.P.I. gegevens -, vast, dat dialysepatiënten in het algemeen verhoogde afweer tonem, waardoor ze moeilijkheden niet toegeven, noch aan zichzeif, noch aan anderen. Short, Wilson e.a. (1969) achten ontkenningsgedrag eigen aan alle kunstnierpatienten.

Beard (1969) stelde bij 79\% van de onderzochte gevallen ontkenningsverschijnseren wast.

Norton (1969) daarentegen meent, dat ontkenmingssymptomen meer worden geduid door de ongeving dan geuit door patiënten.

over de functie van ontkenningsgedrag als zelfbeschermingsmechanisme zijn de meningen minder verdeeld dan over het vöbrkomen ervan. Het verschijnsel ontkenning/verdringing dient in deze zeker niet zonder meer als negatief geĩnterpreteerd te worden. De functie van ontkennen is het anverdraaglijke acceptabel te doen zijn (Goldstein 1976).

Wishfull thinking is als een uiting van ontkenning aan te merken. In dit ka- 
der is dan goed impasbaar "wishfull thinking" met Abran (1970) te beschowwen als bescherming tegen voor de patiënt overweldigende situaties. Wright (1966) signaleert een ontkenning van de werkelijkheid en het miniseren of bagatelliseren van de problemen. Het opbouwen van een verdedigingssysteem lijkt voor patienten in bedrejgende situaties hast onoverkomelijk. In hoeverre worden nu deze gegevens vanuit het onderzoek bevestiad? Het gegeven dat chronische kunstrierpatienten y $50 \mathrm{jr}$ slechts zeer sporadisch ontkenningsgedrag witen, bevestigt de mening van cramond e.a. (1967), dat ontkenning afneemt bij acceptatie van ziekte en die van Norton (1969), dat er niets te antkemnen valt bijmensen die hun toestand reëel onder ogen zien. Inderdad is bij de "chronische" oudere leeftijdsgroep die de kunstnierbehandeling aanvard hebben zonder transplantatieperspectief sprake van een grote mate van acceptatie van deze situatie.

In dat verband is het optreden van ontkenningsverschijnselen bij de doorgangsdialysepatiënten die de behandeling alleen maar ziem als voorbereiding op een transplantatie, aldus short en wilson (1969), op zichzelf al een ontkenning van de realiteit.

Uit de factor 'instelling ten aanzien van de dood' blijkt, dat angst voor de dood het sterkst naar voren kont bij niet-transplantabele kunstnierpatienten $<50 \mathrm{jr}$, hetgeen in overeensterming is met de werkelijkheid, wan de als meest uitzichtsloos beleefde (grens)situatie. Wanneer gesteld wordt $(0 . a$. Beard 1969, Kaplan de Nour 1970) dat anost voor de dood als een bedreigende factor op de achtergrond voortdurend aanwezig is, is dit met het accent op de achtergrond juist. Dit geldt niet voor conclusies als bij Abram (1970) die angst voor de dood als een voortdurende bron van stress ziet. Wel is het 20 , dat situatieve factoren thet sterven van medepatiênten, complicaties, en het vernemen van de diagnose (prognose) gevoelens van doodsangst kunnen versterken. Conform Kaplan de Nour (1976), Wijsenbeek en Munitz (1973) 
is het ook onze ervaring dat het bespreekbar maken van deze gevoelens als thema bij zowel individuele als groepsgesprekken een angstreducerend effect heeft.

War uit de meeste publicaties blijkt, dat de kunstmierpatiënt zijn/haar lot over het algemeen moedig onder ogen ziet en tot acceptatie van de gegeven toestand komt, betekent dit miet dat het in het verlengde hiervan komt tot aanvaarding van een mogelijke dood. Zonder de ervaring van in het aangezicht van de dood te verkeren of te hebben verkeerd, is aanvaarden van de dood slechts een abstractie.

Doorgangsdialysepatiënten aanvaarden dit gegevem minder dan de "chronische" oudere leeftijdsgroep. Woor de groep patiënten die hun toestand als het meest bedreigend ervaren d.w.z. de niet transplantabele jongere leeftijdsgroep, geldt, dat ze in overgrote meerderheid de dood als gegeven mogelijkheid niet aanvaarden, ook al beleven zij hun situatie als hopeloos.

Waar de verschillen enerzijds samenhangen met de leeftijdsfactor - < $50 \mathrm{jr}$ en $>50 \mathrm{jr}$ - moet anderzijds toch worden aangenomen dat de houding, ook die van anvaarding ten aanzien van de dood en de verwerking van de doodsproblematiek zonder meer zulk een persoonsgebonden zaak is, dat het behoren tot én benalde categorie kunstnierpatiënten met betrekking tot deze factor over het algemeen bepald wordt door de persoontijke levens - en (doods)beschouwing.

Het feit, dat op de factor "hoop op medische mogelijkheden" de factorladingen hoog zijn, betekent dat de door ons geformuleerde hypothese van de grenssituatie een belangrijk element mist, namelijk die van de hoop, die door alle wanhoop heenklinkt. Dit geldt ook voor het merendeel van de niet-meertransplantabele kunstnierpatiënten.

Short en Wilson (1969) wijzen erop, dat in deze hoop ook een ontkenning van 
de werkelijkheid kan schuil gaan, het hopen tegen beter weten in.

"They continue to hope that this process will be reserved" (p. 435).

Dok al houdt deze hoop ontkenning van de realiteit in, toch dient zij

positief gewaardeerd te worden voonzover het de patiënt in staat stelt

met $z i j n /$ har situatie (te leren) leven.

In het algemeen houdt de psychologie, al of niet in het voetspoor van de psychopathologie, zich meer bezig met tekorten en afweermechanismen als de zwakke kanten van het menselijke functioneren dan met persoonlijkheidssurplus en positieve coopingsmechanismen, waartoe hoop gerekend kan worden. Over de psychologie van de wanhoop en de depressie is meer geschreven dan over die van de hoop en de berusting (Flügge H.- 1954 ).

De relatief hoge factorladingen op deze factor wijzen op een ander gegeven, namelijk, dat patiënten zich vastklampen aan mogelijkheden die door het dialyseteam niet gezien worden. Cramond e.a. (1968) wijzen in dit verband op de uiteenlopende verwachtingspatronen bij patiënten en staf. De gegevens op deze factor wijzen erop dat kunstmierpatiënten hoop blijven koesteren op medische mogelijkheden, dit geidt met name voor de jongere leeftijdsgroepen.

Hoop en warhoop gaan samen ook in een als grenssituatie beleefde werkelijkheid. In de aanwezigheid van deze hoopgevoelens ligt de correctie die onze uitgangshypothese van de grenssituatie behoeft.

Ten aanzien van de factor vastklampen aan en doorzetten van de behandeling doet zich het probleem voor, dat een beperkt aantal kunstnierpatiënten de wens te kennen geeft hiervoor niet in aanmerking te willen kamen (Abram, 1970, Mc. Kegney, 1971, Loos e.a., 1979).

Hoewel de overgrote meerderheid van de kunstnierpatienten onder alle om- 
standigheden hun behandeling gecontinueerd wenst te zien, bijkt uit de gegevens vanuit de factor "hoop" er voor een aantal van de onderzochte patiénten toch een grens te zijn.

Over het al of niet voortzetten van de behandeling zijn witeenlopende literatuurgegevens te vernelden.

Mc. Kegney (1971) is van mening, dat het niet wensen van de voortzetting van de behandeling een legitieme keus is wan de patiënt.

Dok bimnen het dialysecentrum Mastricht zijn vele discussies gevoerd op grond van zich voordoende casuistiek waruit bleek hoe moeilijk het personeel het op dit punt eens kon worden, met name de verpleging. De inbreng van Prof. Paul Sporken als ethicus heeft in belanarijke mate bijgedragen tot een standpuntbepaling warbij het uitgangspunt van Mc. Kegney wordt gedeeld. Steeds blijkt wadr sprake is van het willen beëindigen van de behandeling en niet alleen in een eindstadium - dat het in deze zaak gaat om de verhouding tussen de medische c.q. verpleegkundige verantwoordelijkheid tot de patiënten en de vraag, in hoeverre de patiënt'zelf zijn lot mag en kan bepalen.

Schreiner en Maher (1966) brengen het niet willen continueren van de behandeling in verband met, het falen van de staf. Ook Beard (1969) meent, dat het hier een kwestie vam begeleiding en opvang betreft. Elkinton (1966) sluit zich aan bij Mc. Kegney waar hij stelt, dat het hier een legitieme keus betreft en dat men onder ogen moet zien, dat de kwalliteit van het leven niet altijd gediend is met een continuering van de behandeling. Binnen de vertrouwensrelatie van arts en patiënt is het voor de laatste vooral van groot belang, zo is ons gebleken, dat de expliciete wens van sommige patiënten niet eindeloos door te gaan met spoelen, serieus wordt genomen en kan worden gehonoreerd. 
Hoewe niet als factor in ons onderzoek bevestigd zal hier toch het thema: 'suifcidale gedachten of neigingen' in de discussie worden betrokken. Op deze factor wardt slechts sporadisch gescoord door doorgangsdialysepatiënten en door diegenen die niet meer voor een transplantatie in aanmerking komen of menen te komen.

Dit is, zij het sporadisch, bij de oudere leeftijdsqroep wel het geval. Deze bevinding vindt bevestigina bij Dorpat (1960), Pokorny (1960) en Farberow (1963) war deze stellen, dat chroniciteit een siqnificante factor vormt ten aanzien van de beslissing tot een suĩcide, al dient hier de nuancering aan toegevoend te worden dat het, meer gat om de neiging dan om de beslissing tot een suĩcide.

Uit het onderzoek is niet gebleken dat surcidaal qedrag voorkont als reactie op de dood van medepatiënten zoals Wijsembeek en Munitz stelien (1973).

Na de factor hoop komen de hoogste factorladingen voor op de factor wanhoop. In de ziektebeleving van ongeveer de helft van alle kunstmierpatiënten speelt deze wanhoop van tijd tot tijd een rol. Waar deze factor de hoogste 'Tading' heeft op het begrip 'grenssituatie' kan deze situatie van toepassing worden geacht op vrijwel de helft van de totale kunstnierpopulatia. Uit de gespreksverslagen wan het vooronderzoek blijkt hoe deze belevingsaspecten wan de wanhoop aansluiten bij de ervaringen van diverse auteurs, die deze ervaringen veelal incidenteel en niet valdoende geexpliciteerd memoreren. Enelow e.a. (1967), idem Villard (1969) noemer depressies, angstreacties, zelfmoord-neigingen of -pogingen in verband net wanhoopsreacties. Friedman (1970) brengt wanhoop in verband met steeds terugkerende compli. caties.

Sprekend over de communicatiekloof tussen patienten en personeel in bedraigende situaties, stelt Mc. Kegney (1971) vast, dat het hiet funnen voldoen aan de verwachtingen van thwis en de afdeling de wanhoop verstert. 
ook het links laten liggen wanuit onmachtsgevoelens bekrachtigt deze wanhoop.

De beleving van deze grenssituatiefactor die significant meer voorkont bij niet-transplantabele ten opzichte van transplantabele patiënten die hun situatie als een doorgangssituatie beleven of hebben beleefd, verwijst naar de betekenis van deze grenssituatie voor kunstnierpatiënten zonder transplantatie-verwachtingen en/of -zekerheid.

Het is mogelijk de factoren hoop en wanhoop of de verwachtingen ten aanzien van een niertranspliantatie toe te lichten met enkele feitelijke gegevens betreffende overlevingskansen.

In een rapport van de European Dialysis and Transplantation Association (1976) worden overlevingspercentages gegeven van kunstnierpatiënten en getransplanteerde patiënten in de bij deze organisatie aangesloten landen (28).

De geniddelden worden hïeronder vermeld naar leeftijdscategoriën.
$n=25 \cdot 310$
$1 j r$.
$3 \mathrm{jr}$.
$6 \mathrm{jr}$.

$15-34$ jaar

$\begin{array}{lllll}\text { Ziekenhuisdialyse } & (8713) & 87 \% & 72 \% & 63 \% \\ \text { Getransplanteend } & (2594) & 77 \% & 66 \% & 52 \%\end{array}$

35 - 44 jaar

Ziekenhuisdialyse

$85 \%$

$64 \%$

$46 \%$

Getransplanteerd

$69 \%$

$55 \%$

$44 \%$ 
$45-54$ jaar

Ziekenhuisdialyse

(5401)

83 絮

59 \%

$36 \%$

Getransplanteerd

$61 \%$

$47 \%$

$34 \%$

$55-64$ jaar

Ziekenhuisdialyse

$78 \%$

$51 \%$

$25 \%$

Getransplanteerd

$54 \%$

$38 \%$

Wit deze gegevens blijkt, dat de levenskansen dalen bij toename van dialyseduur en dat deze daling groter is bij toename van de leeftijd.

Wij vervalgen dit overzicht met enkele opmerkingen over de sexualiteitsbeleving bij kunstnierpatiënten en vernelden tenslotte enkele gegevens met betrekking tot het al of niet opgenomen zijn in het arbeidsproces.

Bij factoranalyse kwam de factor 'sexualiteit' naar voren, die niet in de aanvankelijke clusterindeling van uitspraken voorkwam. Gesteld werd, dat spanningen in de huwelijksrelatie ook met frustratie in de beleefde huwelijksrelatie kunnen samenhangen.

De onderzoeksgegevens van de uitsprakenlijst rechtvaardigen de conclusie dat er verandering is apgetreden in de sexualiteitsbeleving van kunstnierpatienten. Over deze verandering in de sexualiteitsbeleving zijn vrij exacte literatuurgegevens bekend waarvan enkele hier worden genoemd, als nadere verklaring voor de aanwijzingen die hierover ook uit ons onderzoek naar voren 1ijken te komen.

Zowel Abram als Levy (1974) die beide onderzoek verrichtten ruar de sexualiteitsbeleving bij kunstnier-en getransplanteerde patiënten, komen tot de conclusie, dat bij ruim $2 / 3$ van de kunstnierpatienten sprake is van libido- 
verlies, bij mannen overigens meer het geval dan bij vrouwen.

Bij $1 / 3$ var de kunstnierpatiënten bleek er qeen verandering aantoonbaar in deze sexualiteitsbeleving als gevolg van nierlijden en/of kunstnierbehandeling.

Abram meldt zelfs in $78 \%$ van de onderzochte populatie vermindering in de frequentie van thet sexuele contact hetgeen door vrijwel alle patienten in verband wordt gebracht met de fysieke en niet met de psychische situatie. overigens constateerde hij ook bij getransplanteerde patiënten in $40 \%$ van de gevallen 7 ibidovermindering.

Van $1 / 3$ tot 1/4 wan de kunstnierpatiënten wordt derhalve geen verandering in de sexualiteitsbeleving angegeven.

Hoewel wij niet over de exacte cijfers in deze beschikken is er geen reden on deze gegevens ook niet als indicatief te beschouwen voor de nederlandse kunstnierpopulatie.

De onderzoeksresultaten met betrekking tot de handhaving in het arbeidsproces (tabel 1) steken onqunstig af bij de in de literatuur hierover vermelde geovens.

Voor Nederland geldt, dat slechts $27 \%$ zich geheel of gedeeltelijk in een arbeidssituatie heeft weten te handhaven; $52 \%$ werkt niet meer. De verschillen tem aanzien van het buitenland $z$ ijn wellicht minder pregnant, wanneer in aanmerking wordt genomen dat . in tegenstelling tot het onderhavige onderzoek - de meeste onderzoeken betrekking hebben op een periode tot 2 jaar na ansluiting op de kunstmier. Waarschijnlijk is dan ook, dat bij langere dialyseduur de mogelijkheid tot handhaving in het arbeidsproces afneemt. Dam nog lijkt er van een verschil sprake, bij welk verschil wellicht de volgende onstandigheden een rol spelen:

a. de relatief betere sociale voorzieningen in Nederland. 
b. het naar verhouding lagere percentage thuisdialysepatienten in Nederland.

Het is een bekend verschijnse?, dat thuisdialysepatiënten - doorgaans een geselecteerde groep - dialyseren en werken over het algemeen goed weet te combineren $(70-80 \%)$.

De volgende literatuurgegevens bevestigen deze algemene indruk.

Levy e.a. (1974) noemen het percentage van $37 \%$ centrumdialysepatiënten die na twee jaar nog opgenomen zijn in het arbeidsproces, voor thuisdialysepatiënten is dit $73 \%$.

Malmquist, Hogberg (1973) en Goldberg (1975) vermelden hiermee overeenkomende verhoudingsqetallen. Zij wijzen op de verschillen in dit opzicht tussen de diverse landen en stellem terecht dat de uiteenlopende percentages in dit opzicht o.a. samenhangen met gehanteerde selectiecriteria en verschillen ten aanzien van sociale regelingen.

Levy (1974) citeert een op internationale gegevens berustend onderzoek van Wing en Brunner ( 715 centra in 28 Europese landen) aan de hand van de volgende gegevens: na 2 jaar: centrumdialysepatiënten $37 \%$ arbeidsproductief thuisdialysepatiënten $\quad 73 \%$ arbeidsproductief getransplant. patiënten $76 \%$ arbeidsproductief

Blag en Gross (1976) vermelden voor thuisdialysepatiënten percentages van $82 \%$

Goldberg (1974) geeft overigens op een kleiner sample gebaseerd Amerikaans onderzoek, hiervan afwijkende cijfers $(n=99)$;

doorqangsdialysepatiënten $28 \%$ arbeidsproductief getransplant. patiënten $56^{\circ}$ arbeidsproductief chronische dial.patiënten $86 \%$ arbeidsproductief 
Deze laatste cijfers dienen - aldus een persoontijke mededeling van Levy - gezien te worden in relatie tot de Amerikaanse wetgeving die aanmerkelijk slechtere sociale uitkeringsregelingen kent dan westEuropa.

Eigen ervaringen leerden ons, dat het voor kunstnierpatiénten uitermate moeilijk is om de werksituatie op een bevredigende manier met de behandelingssituatie te combineren en zo komt ons de opmerking, door een Amerikaans sociaal werker, gemaakt tijdens een paneldiscussie (geciteerd door Abram, in een door Levy geredigeerde studie, 1974) als juist voor, die stelde dat de dialysepatiënt die klaar moet komen met de dialysesituatie als zodlanig voldoende werk heeft met zichzelf "we moeten er aan denken hen niet te overuragen door te eisen dat hij zijn werk weer zal herwatten".

De onderzoeksresultaten m.b.t. werken en dialyseduur leren dat het van groot belang is continuering van arbeidsmogelijkheden te realiseren voor die patienten voor wie dat in principe mogelijk is en daarbij de dialyseduur, in afwachting van een niertransplantatie, zo kort mogelijk te houden. 
Nabeschouwing.

Wat voor de somatische toestand van kunstnierpatienten geldt is ook van toepassing op het psychische toestandsbeeld: het geheel van belevingsaspecten; verwerkingsmechanismen en reactiepatronen.

Men kam niet spreken van de toestand warin de dialysepatienten verkeren. In een gegeneraliseerd beeld herkent de kunstnierpatient zich doorgaans niet.

De bijdrage van dit onderzaek is het kunnen aantonen van de verschillen in belevingsaspecten bij wel en niet meer voor een transplantatie in aanmerking komende kunstnierpatienten. Oak voor psychologen en psychiaters al of niet als consulent verbonden aan de dialysecentra en uit hoofde van hun beroep wooral bemoeienis hebbend met die patienten voor wie het verwerkingsproces nroblematisch verloopt, geldt dat ze op grond van hun ervaringen met een, over het algemeen beperkte selectie van kunstnierpatienten, witerst voorzichtig dienen te zijn met generalisaties.

Wie in dit opzicht over de schreef gaat wordt - gelukkig - "teruggefloten" door de eigen of doior anderen gegeven onderzoeksresultaten,zeker als deze empirisch en methadologisch goed zijn onderbouwd.

Juist t.a.v. Kunstnierpatienten is door het vermelden van niet representatieve steekproefresultaten (te kleine samples) in het recente verleden een te fragmentarische en vaak eenzijdig beeld naar voren gekonen.

onze beschreven onderzoeksresultaten vormen ook daarop een correctie.

Tenslotte wijst dit onderzaek in de richting wan de noodzaak de belevingswereld van de kunstnierpatiënten nader te expliciteren aan de hand van variabelen als leeftijd, geslacht, al of niet gehuwd zijn, dialysedur en het al of niet opgenomen zijn in het arbeidsproces.

Met betrekking tot de Tatsgenoende variabelen is in dit onderzoek reeds een aanzet gegeven. 


\section{Samenvatting}

Het beschreven onderzoek is gericht op verkrijgen van inzicht in de belevingsaspecten van patienten die worden behandeld met een kunstnier. In een literatuuroverzicht (Hfd. I) werden de meest op de voorgrond tredende psychosociale aspecten wan deze nierfunctievervangende behandeling wermeld.

De veronderstelling die aan dit onderzoek ten grondslag ligt is dat deze belevingsaspecten samenhangen met verschillen in behandelingssittuatie en dienovereenkomstig perspectief, N.1. het al of niet in aanmerking komen voor een niertransplantatie. nerhalve werd onderscheid gemakt tussen drie groepen of categorieën kunstnierpatienten.

a. doorgangsdialysepatienten, diegenen die in principe voor een niertransplantatie in aanmerking komen en als zodaniggeregistreerd staan bij Eurotransplant (de "databank" in Leiden war alle gegevens van uit een aantal Europese landen afkomstige nierpatienten, geregistreed zijn). Deze patienten dialyseren in afwachting van een niertransplantatie. De gemiddelde wachttijd hiervoor is +21 jaar.

b. de chronische dialysepatienten, chronisch d.w.z. zonder transplantatieperspectief op basis van een leeftijdscriterium ( $>50$ jaar)

c. kunstnierpatienten die na een of meer mislukte transplantaties of om andere medische redenen niet meer transplantabel zijn.

Deze groep omvat een iongere leeftijdsgroep ( $<50$ jaar) die chronisch zijn, chronisch in de zin van niet (meer) transplantabel.

De probleemstelling in dit onderzoek als uitgangspunt geformuleerd berust op de volgende vragen:

I. Is het mogelijk de situatie van de kunstnierpatient te omschrijven aan de hand van de op deze drie categorieën van toepassing zijnde belevingsaspecten?

II. Is het mogelijk de veronderstelling rond het begrip grenssituatie -een aan de filosoof Jaspers ontleende en door enkele auteurs (Mc. Kegney 1976 , Freyberger 1968, Fellner 1976) op kunstnierpatienten van toepassing geachte omschrijuing-nader te expliciterenc.q.te beschrijven aan de hand van onderzoeksgegevens.

Het onderzoek zelf omvat twee onderdelen:

1. een vooronderzoek:

Hiwin is het onderzoeksmateriaal verwerkt en beschreven op bas is van veertig 
semigestructureerde interviews bij dertig kunstnierpatienten, representatief voor de hierboven omschreven drie categorieën kunstnierpatienten en een vergelijkingsgroep van tien carcinoompatienten.

Deze interviewgegevens werden op inhoudsanalyse gescoord (volgens het. principe van de meervoudige beoordelaar) aan de hand van een conceptueel model bestaande uit dertien op face-value geformuleerde clusters, warin 57 door kunstnierpatienten gedane uitspraken zijn verwerkt (Bijlage II). De conclusies uit dit vooronderzoek rechtvaardigen de veronderstelling dat t.a.v. de psychologische belevingswereld verschillen kumnen worden aangetoond tussen wel en niet voor een transplantatie in aanmerking konende kunstnierpatienten.

Dit onderscheid kan echter niet worden gehandhaafd terzake van chronische kunstnierpatienten > en < 50 jaar.

ook t.a.v. het tweede onderdeel der probleemstelling, de veronderstelling vanuit het concept "grenssituatie" blijkt differentiatie slechts mogelijk tussen wel en niet voor een transplantatie in aanmerking komende kunstnierpatienten.

Om meer inzicht te krijgen in de aard en betekenis van deze verschillende belevingsaspecten bij twee onderscheiden groepen kunstnierpatienten werd vanuit de onderzoekresultaten van het vooronderzoek een aantal hypothesen afgeleid en geformuleerd. Deze vormen de basis van het eigen 1 ijke onderzoek dat plats vand bij een representatieve steekproef van honderdveertig kunstnierpatienten, verdeeld over verschillende kunstniercentra in Nederland. Hfd. 4 geeft een beschrijving van dat onderzoek. Ondat niet uitgesloten is dat nast de verschillen in behandelingssituatie ook andere variabelen van invloed zijn op de belevingswereld van kunstnierpatienten werden in de opzet van dit onderzoek de volgende onafhankelijke variabelen toegevoegd naast het behoren tot eén der onderscheiden groepen kunstnierpatienten n1.: leeftijdscategorie, geslacht, burgelijke status, opleidingsniveau, dialyseduur en werken.

Bij de methode van onderzoek werd gebruik gemakt van drie instrumenten:

- een vragenlijst ( 18 items).

- een uitsprakentijst ( 57 uitspraken).

- een semantische differentiaal.

op de gegevens van het vragentijst-onderzoek werd een variantie-analyse toegepast (Bijlage VI). 
De onderzoeksresultaten m.b.t. de uitsprakenlijst en de semantische differential berusten on factoranalytische bevindingen.

In tabel 14 zijn de kwantitatieve gegevens vermeld m.b.t. het vragenlijst onderzoek.

De op de 57 uitspraken uitgevoerde factoranalyse van de uitsprakerlijst makte het mogelijk de oorspronkelijk op basis van de dertien op face-value ingedeelde clusters warin deze 57 uitspraken, die representatief werden geacht voor de psychologische belevingswereld werden opgenomen, te herformuleren in 9 factoren $n 1$. angst woor de kunstnier, houding t.a.v. de partner, verlies van eigenwaarde en toekomstperspectief, instelling t.a.v. de dood, hoop op medische mogelijkheden, vastklampen aan en doorzetten van de behandeling, wanhoop en sexualiteit.

Uit de onderzoeksresultaten kan worden afgeleid dat de verschillen in beleving tussen wel en niet voor een transplantatie in aanmerking komende kunstnierpatienten met name betrekking hebben op de clusters of factoren: hoop/vastklampen aan medische mogelijkheden, wanhoop/hopeloosheid en het aanvaarden van de dood als mogelijkhejd.

In Hfd. 5 worden de onderzoeksresultaten beschreven aan de hand van de semantische differential. Uitgangspunt hierbij is de vraag in hoeverre de belevingswereld van kunstnierpatienten zich laat beschrijven met betrekking tot de gekozen instituuts- persoons- en situatiebegripnen. Van de oorspronkelijk tien gekozen begrippen: het ziekenhuis, de kunstnierafdeling, de dokter, de verpleegster, mijn man/vrouw, de kunstnier, aan het werk blijven, dialyseren, getransplanteerd worden en sterven konden al leen de onderzoeksresultaten m.b.t. zes begrippen worden beschreven.

Het bleek dat de drie betekenisdimensies door osgood in zijn beschrijving van de semantische differential gegeven $n$ l. wardering, potentie en activiteit, over het algemeen zijn terua te vinden binnen de factoranalytische bevindingen van dit onderzoek, zij het met een enigszins andere verdeling van de voor deze factoren meest typerende contrastparen. lit het semantische differentiaal onderzoek kan worden geconcludeerd dat de aan het ziekenhuis en de afdeling toegekende eigenschappen de afhankelijkheidspositie van kunstnierpatienten weergeeft.

Aan arts en veroleegkundigen worden nast de aan deze functionarissen toegekende efficiency van handelen juist ook beschermende kwa ${ }^{7}$ teiten toegekend. 
Kunstnier en dialyseren worden als toevluchtsmogelijkheden beleefd, als een effectieve behandelingsvorm die zekerheid en veiligheid biedt.

De wijze warrop de kunstnierbehandeling in psychologisch opzicht wordt beleefd blijkt in belangrijke mate bepald te worden door:

a. het al of niet in aanmerking komen voom een transplantatie.

b. het al of niet opgenomen zijn in het arbeidsproces en

c. de lengte van de dialyseduur, in casu korter of langer dan 3 jaar dialyseren.

In Hfd. 6 worden de onderzoeksresultaten op basis van de factoranalytische bevindingen vergeleken met de hierover gepubliceerde literaturgegevens. 
This study aims at gaining an insight into the experience of patients who are treated by hemodialysis.

In ch.l the most striking psychosocial aspects of this treatment are described from literature.

The assumption underlying this study is that these experiences are inked up with differences in treatment-situations and attendant perspective, viz. whether the patient is considered for a kidney transplantation or not. Consequently we distinguished between three groups or categories of dialysis patients.

a. transit diallysis patients, those who, in principle, are considered for a kidney transplantation and who are rigistered as such at Eurotransplant (the databank at Leyden where all the data of patients from a number of European countries are registered).

These patients dialyse while awaiting their kidney transplantation. The average wait for this is about thirty months.

b. chronic dialysis patients; chronic means without a perspective of tranplantation based on an age criterion $(>50)$.

c. dialysis patients who are no longer transplantable, after one or more unsuccessful transplantations or on account of other medical reasons. This category comprises a younger age group $(<50)$ who are chronic, in the sense of not (or no more) transplantable.

The problem definition in this study formulated as starting-point, is based on the following questions:

I. Is it possible to define the situation of the dialysis patient on the basis of the experiences applicable to the three categories?

II. Is it possible to make more explicit or to describe the assumption concerning the concept 'extreme situation' from research data. The definition 'extrene situation' is borrowed from the philosopher laspers; it was considered to be applicable to dialysis patients by some authors (Mc. Kegney, 1976, Freyberger, 1968, Fellner, 1976). 
The research itself includes two parts:

1. a preliminary investigation:

In this investigation the research material has been incorporated and described on the basis af forty semi-structured interviews with thinty dialysis patients, representative of the three categories of dialysis patients, defined above, and a parallel group of ten carcinoma patients. These interview data were scored at content - analysis (according to the princple of multiple judge ( 3 judges) with the help of a conceptual model consisting of thirteen face value formulated clusters, in which 57 statements by dialysis patients have been incorporated (Appendix II). The conclusions from this preliminary investigation justify the assumption that, as to the psychological world of experience, differences can be proved between the dialysis patients who were considered for a transplantation and those who were not.

This distinction cannot be maintained with regard to chronic dialysis-patients $>$ and $<50$.

As to the second part of the problem-statement, the asumption based on the concept of "extreme situation', differentation also appears to be possible only between dialysis-patients who are, and patients who are not considered for a transplantation.

To gain more insight into nature and meaning of these different aspects of experience in two distinct groups of dialysis patients, a number of hypotheses were deduced and formulated from the research results of the preliminary investigation.

These constitute the basis of the actual study which took place among a random sample of one hundred and forty dialysis patients, distributed over sixteen dialys is centres in The Netherlands.

Chapter four describes that investigation, beside the differences in treatmentsituations, other variables will affect the world of experiences of dialysis. patients too.

Therefore, in the plan of this study, the following independant variables were added to the one stating a patient belonged to one of the differentiated groups viz.: age category, sex, married or unmarried, level of education and duration of dialysis.

In the research method three instruments were used:

- an itemlist (18 items)

- list of statements (57 statements) 
- an 0sgood scale

A variance analysis was applied to the data of the item-list (Appendix IV). The research results regarding the list of statements and the 0sgood scale, are based on factor-analytical findings.

Table 14 gives the quantitative data regarding the item-list research.

The factor analysis of the list of statements, carried out on the basis of 57 statements, made it possible to reformulate the clusters originally classified on face value.

These clusters, in which the 57 statements were included were considered to be representative of the psychological warld of experience, could be re-formulated into nine factors viz.: fear of the kidney-machine, attitude towards the partner, loss of self-respect and future-expectancy, attitude towards death, hope for medical possibillities, dinging to and pressing on the treatment, despair and sexuality.

From the research results can be concluded that the differences in experience(s) between those patients who were, and those who were not considered for a transplantation, are notably related to the clusters or factors: hope/ dinging to medical possibilities, despair/hopelessness and the acceptation of a possible death.

In chapter 5 the research results are described on the basis of the osgood scale. The point of departure in this is the question to what extent the world of experience of dialysis patients can be described in relation to the chosen institute-, person- and situation-concepts.

originally we had chosen ten concepts: the hospital, the dialys is department, the doctor, the nurse, my husband/wife, the kidney machine, continuation of work, dialysing, having a transplantation and dying.

of these only the research results relating to six concepts could be described. It appeared that the three dimensions of signification given by osgood in his semantic differential, viz. appreciation, potency and activity, in general can be recovered within the factor-analytical findings of this research, be it with a slighty different division of the contrast pairs that are most typical of these factors.

From the 0sgood scale results can be deduced that the qualities attributed to the hospital and the department, reflect the state of dependance of the dialysis patients.

The patients think that the doctor and the nurses act efficiently but they also attribute protective oulities to these functionaries. 
Finally kidney machine and dialysing are experienced as refuges, as an effective way of treatment offering security and safety.

In chapter 6 the results of this study on the basis of factor analytical findings are compared with the data given in literature on this matter. Three variables are important in distinguishing the psycholagical field of experience:

- applicable for a kidney transplant or not

- being at work or not

- duration of hemodialysis treatment shorter or longer than three years. 
Geraadpleegde literatuur: 
GERAAD"PLEEGDE-ENAANBEVOLEN LITERATUUR

ABRAM, H.S. The psychiatrist, the treatment of chronic renal fai-

Ture, and the prolongation of life: I

Amer. d. Psychiat. 124 (1968) 10, apri1, p. 1351-1358

ABRAM, H.S. The psychiatrist, the treatment of chronic renal fai-

lure, and the prolongation of life: II

Amer. J. Psychiat. 126 (1969) (a) p. 157-167.

ABRAM, H.S. Psychotherapy in renal failure. In Massernan, J.H. (ed):

Current psychiatric therapies, vol. IX, (1969) (b)

Grune and Stratton, New York.

ABRAM, H.S. Survival by machine: the psychological stress of chronic haemodialysis.

Psychiatry in Medicine, vol. 1, no. 1, 1970.

ABRAM, H.S., MOORE, G.L., WESTERVELT, F.B. Suicidal behavior in chronic dialysis patients.

Amer. d. Psychiat. 127 (1971) p. 1199-1204.

ABRAM, H.S. Suicidal behavior in chronic dialysis patients.

Amer. J. Psychiat. 127 p. 1199-1204.

ABRAM, H.S., HESTER, L.R., EPSTEIN, B.A., SHERIDAM, W.F.

Sexual activity and renal failure. Proceedings of the

fifth international Congress of Nephrology,

S. Karger, Base1, 1973.

ADVIES INZAKE HAEMODIALYSE EN TRANSPLANTATIE, no. 21, Ministerie van Volksgezondheid, verslagen en rapporten, 1972 ,

St. witg.: Den Haag 1972.

ALEXANDER, $L$. The double-blind theory and haenodialysis.

Arch. Gen. Psychiatry, vol. 33, nov. 1976.

ANDERSON, J.C. e.a., Living with renal failure, Edinburg, 1978.

ARMSTRONG, S.H. The psychologist's place in chronic in. center haemodialysis. Dialysis and Transplantation, vol. 3 , No. 6, oct/nov. 1974.

BARBER, N.D. e.a. Trans. Amer. Soc. Artif. Organs, 9.21. 1963.

BARTELS, A.J.H. Macht over leven en doad.

Referaat Medische Faculteitsvereniging, Nijmegen, Mei 1967.

BARTH, K. Kirchliche Dogmatik, deel III, bnd. IV, 1948. 
BEARD, B.H. The quality of 1 ife before and after renal transplantation, Diseases of the nervous system, january 1971.

BECKER, J.B., BROWN, R., WALKER, L. Dialys is staff opinion survey. Dialysis and transplantation, july 1977.

BERG w.d. J.H. Psychologie wan het ziekbed, Nijkerk, 1954.

BIERKENS, P.B. Enige ervaringen bij de psychologische selectie van patiënten voor intermitterende haemodialyse. Katholiek Artsenblad, dec. 1967, no. 12.

BOM, J.A. v.d., BROEK, M.J.M. w.d. Psychologische aspecten van nierfunctievervangende behanaeling.

Vakgroep antwikkelings-Psychologie/Psychogerontologie, Kath. Unviersiteit Nijmegen, 1975.

BREMER, J.J.C.B., de Ziekenhuispatiënt, Nijmegen, 1964, 2e druk 1972.

BRENGELMAN, J.C. Die Aufgaben des Psychologen bei der Dauerdiallyse und Niertransplantation.

Munchener Med. Wochenschr. 110 (1968).

BROWN, H.W., MAHER, J.F. Clinical problems related to the prolonged artificial maintenance of life by haemodialysis in chronic renal failure.

Trans. Amer. Soc. Artif. Organs, 8 (1962).

BUCHANAN, D.C., ABRAM, H.S. Psychological adaptation to haemodialysis. Dialysis and Transplantation, febr./march 1976.

CALLAND, C.H. Iatrogenic problems in end-stage renal failure. The new england journal of medicine, vol. 287, no. 7 , aug. 1972.

CAZZULLO, C.L., INVERNIZZI, G., VENTURA, R., SOSTERO, M. Psychosomatic Implications of Psychasomatic Research. 9th Europ. Conf. Psychosom. Res., Vienna 1972 psychother. Psychosom. 22 : $346(1973)$.

CERLEN, J. Counseling the chronic haemodialysis patient Dialysis and transplantation, vol. 7, no. 6, june 1978. CRAMOND, W.A., KNIGHT, P.R., LAWRENCE, J.R. e.a. Psychological Aspects of the Managment of Chronic Renal Failure.

Brit. Med. Journal 2 mrt. 1 (1968) p. 539-543. 
CRAMONO, W.A. The psychological problems of renal dialysis and trans-

plantation.

Modern trends in psychosomatic medicine, 2nd ed.

Butterworths, London 1970.

CROSBY, D.L. Emotional problems in a chronic haemodialys is unit.

The Lancet, November 30, 1968.

CURTIS, J.R. e.a. Maintenance haemodialysis.

The Quarterly J. of Med. 38 (1969) p. 79 89.

CZACZKES, Ph.D., KAPLAN DE NOUR, A. Chronic haemodialyses as a way of live.

New York, 1978.

DALY, R.J. Psychiatric aspects of maintenance haemodialyses.

Proceedings of the 4th Internal Congress of Nephrology,

Karger, Basel, 1969, p. 121-130.

DANSAK, D.A. Secondary Gain in Long Term haemodialys is Patients.

Amer. J. Psychiat. 129, 3 september 1972.

DECKER, R.S. Vocational placement services for the renal disease client.

Dialys is and transplantation, vol. 7, no. 6, june 1978.

DIEDERIKS, J.P.M. Typen patiënten en hun begeleiding.

T. Soc. Geneesk. 52 (1974) p. 45-50.

DIEKSTRA, R.W.F. Crisis en gedragskeuze: een theoretische en empirische

bijdrage tot het zelfmoordprobleem.

Swets en Zeitlinger, Ansterdam 1973.

DORHOUT MEES, E.J. Mogelijkheden wan intermitterende dialyse.

Ned. T. v. Geneesk. 115 (1971) p. 235-241.

DORPAT, T.L., RUPLEY, H.S. A study of suicide in the Seattle area.

Compr. Psychiat. 1 (1960) p. 349-359.

DRUKKER, W. e.a. Report on regular dialys is treatment in Europe.

Proc. Eur. Dial. transplant. Assoc. 1970, p. 25-32.

ELKINTON, J.R. Medicine and the Quality of Life.

Ann. Int. Med. 64 (1966) no. 3, March.

ENGEL, G.L. A psychological setting of somatic disease:

The 'giing up - given up' complex.

Proc. R. Soc. Med. 60 (1967) June. 
FOSTER, F.G., COHN, G.L. MCKEGNEY, F.G., PSychobiologic factors and individual survival on chronic renal haemodialysis,

A two year follow up: Part 1 .

Psychosom. Med. 35 (1973) no. 1.

FOX, R.C. A sociological perspective on organ transplantation and haemodialysis. Ann. N.Y. Acad. Sci. 1970, p.406-428.

FOX, R.C., SWANEY, I.P., The courage to fall.

Chicago Uniw. Press, Chicago-London 1974.

FREEMAN, R.B. "MAHER, J.F., SCHREINER, G.E., Haemodialys is for Chronic

Renal Failure.

Ann. Int. Med. 62 (1965) no.3, March.

FREYBERGER, H. Praxis der Intensivbehandlung, München, 1968.

FREYBERGER, H. Six Year's Experience as a Psychosomaticist in a Haemodialysis Unit.

Topics of Psychosomatic Research, 9th Europ. Conf.

Psychosom. Res., Vienna 1972

Psychother. Psychosom. 22: 226-232 (1973)

FRIEDMAN, E.A., GOODWIN, N.J. Psychosocial Adjustment of family to maintenance haemodialysis.

New York St. J. Med. 70 (1970) March.

GALTUNG, J. Theory and Methods of Social Research, 0s10, 1967.

CENTRY W.D., OAVIS G.C. - Cross sectional analysis of psycholosical adapta-

tion to chronic hemodialysis. Journ. of chron. visease 25:'72.

GLASMAN, M.L., LE SHAN, E. PSychotherapy with the patient with a limited

life span. Psychiatry, 24 (1961) 318-323.

GLASMAN, B.M., SIEGEL, A. Personality Correlates of Survival in a Long-

Term Haemodialysis Program.

Arch. Gen. Psychiat. 22 (1970) June, 566-574.

GOLDBERG, R.T. Rehabilitation of Patients on chronic Haemodialysis

and after Renal Transplantation: a comparative study.

Scand. J. Rehab. Med. 6 (1974) 65-69.

GOLDSTEIN, A.M., REZNIKOFF, M. Suicide in Chronic Haenodialysis Patients

from an External Locus of Control Framework.

Amer. J. Psychiat. 127 (1971) 9, March.

GOLDSTEIN, A.M., REZNIKOFF, M. MMPI Performance in Chronic Medical Illness:

The use of Computer-Derived Interpretations.

Brit. J. Psychiat. febr. (1972) 120. 
GOLDSTEIN, A.M. The Subjective Experience of Denial in an objective Investigation of chronically ill patients.

Psychosomatics, 13 Jan-Febr. (1972) $20-22$.

GOMBOS, E.A., LEE, T.H. e.a. One year"s experience with an intermittent dialysis program. Ann. Int. Med. 61 (1964) 642-649.

GOoDEY, Josephine, KELLY, Josephine. Social and Economic Effects of

Reguiar Dialysis.

The Lancet 15 july (1967) 147-148.

GREENBERG, R.P., DAVIS, G., MASSEY, R. The psychological evaluation of patients for a kidney transplant and haemodialysis program. Ann. J. Psychiat. 130 (1973) 3 mrt.

GREENBERG, S. Group process with dialysis patients and their families. Dialysis and Transplantation 3 (1974) no.6, oct/nov.

GREENBERG, J.M., WHITE, S. e.a. Factors of adjustment in chronic haemodialys is patients.

Psychosomatics, 16 (1975) no. 4.

GREENBERG, M.D. Personality and adjustment in hamodialysis patients.

Dialysis and transplantation, november 1977.

GROENMAN, N.H. Zelfbeeld en borstbeeld, Groningen, 1978.

GuTTSCH, C.F. e.a. Ann. Int. Med. 60 (1964) p. 289.

HACKETT, CASSEM, N.H. In: "PSychosocial aspects of terminal care".

B. Schönberg, A.C. Carr e.a.,

Columb. univ. press, New York/London 1972.

HAGBERG, B. A prospective study of patients in chronic haemodialysis III. Predictive value of intelligence cognitive deficit and ego defence structures in rehabilitation.

Journal of Psychosomatic Research, vol. 18, pp. 151-160, Pergamon Press, 1974.

HAGBERG, B., MALMOUIST, A. A prospective study of patients in chronic haemodialys is IV.

J. of Psychosom. Research, 18 (1974) p. 315-319.

Harari $A$. Psychological examination of patients and Families during Henodialysis.

Tel Aviv-University $19 \% 1$.

HATTINGA VERSCHURE, J.C.M. "Project", Tijdschr. voor toegepaste wetenschappen, no. 10: Geneeskunde en Technologie, dec. 1973. 
HENDERSON, $E$. The approach to the patients with an incurable disease.

In: "Psychosocial aspects of terminal care" ed. by

Schönberg, B en Carr, A.C.

Witg. Columbia Press, New York/London, 1972.

HOLCOMB, J.L., MACDONALD, R.W., Social functioning of artificial kidney

patients. Soc. Sci. \& Med. 1973, vol. 7, pp. 109-119.

HOOGSTRATEN, J. Selectie wan patienten woor behandeling met een kunstnier. Amsterdari 1970, scriptie G.U.

HUBER, W. STRAUCH-RAHAUSER, G. e.a. Factors influencing Rehabilitation in Regular Haemodialysis.

A stardardised questionnaire in 222 patients, 1972.

ISIADINSO, 0.A., SULLIVAN, J.F., BAXTER, J.E. PSychological adaptation to long-term haemodialysis, a study of 84 patients.

Bul1, N.Y. Acad, Med. vol. 51, no.7, july-august, 1975.

IASPERS, K. Allgemeine Psychopathologie. Berlin, Springer Verlag, 1948.

JASPERS, K. Philisophie. Berlin, 1948, p. 201 e.v.

JONKER, H. De mens in de grenssituatie. Wageningen, 1952.

KAPLAN OE NOUR, CZACZKES, J.W. PSychological and psychiatric observations on patients in chronic haemodialysis.

In: Kerr, 0.N.S. (ed.): Proc. E.D.T.A., 5 (1968) p. 67-70,

Excerpta Medica Foundation, Amsterdan 1969.

KAPLAN DE NOUR, A., CZACZKES, J.W. Professional team opinion and Personal

Bias-A study of a chronic haemodialysis Unit Team.

J. Chron. Dis. 24 (1971) pp. 533-541.

KAPLAM DE NOUR, A., e.a. Personality factors in chronic haemodialysis patients causing non-compliance with medical regime.

Psych. Som. Med. 34 (1972) pp. 333-344.

KAPLAN DE MOUR, A. Role and reactions of psychiatrists in chronic

haenodialys is programs.

Psychiatry in medicine, vol. 4, no. 1, 1973.

KAPLAN DE NOUR, A., CZACZKES, J.W., Team-Patient Interaction in Chronic Haemodialysis units.

Psychother. Psychosom. 24: pp. 132-136, 1974.

KAPLAN DE NOUR, A. Haemodialysis: sexual functioning.

Psychosomatics, vol. 19, no.4, april 1978. 
KAYE, R., LEIGH, H., STRAUCH, B. The role of the liaison psychiatrist in a haemodialysis program, a case study.

Psychiatry in medicine, vol. 4, no. 3, 1973.

MCKEGNEY, P., LANGE, P. The decision to no longer life on chronic haemodialysis. Amer. J. Psychiat. 128 (1971) 3 Sept. pp. $267-247$.

KEMPH, J.P. Renal failure artificial kidney and kidney transplant. Amer. J. Psychiat. 122 (1966) pp. 1270-1274.

KEMPH, J.P. Psychotherapy with patients receiving kidney transplant. Amer. J. Psychiat. 124 (1967) 5 Nov. pp. 1270-1274.

KESSEL, M., KUCHENBUCH, A. Psychologisch-psychiatrische Aspekte bei chronisch intermittierende Dauerdialyse. Ver. d. Deutsche Geselischaft für innere Medizin, (1967) pp. 995-997.

KILPATRICK, D.G. e.a. Locus of Control and adjustment to long-term haeniodiaiysis. Proceedings 80th Annual Convention APA 1972, pp. 727.

KOUWER, B.J. Een bewerking van de polariteitsprofielenmethode van Osgood. Ned. Tijdschrift $v$. Psycrologie, 13, 1958.

LEE, H.K., PATEL, AA. Psychiatric factors and non-compliant behavior in haemodialysis.

Dialys is and transplantation, vol. 7, no.12, dec. 1978.

LEVY, N.B. Sexual adjustment to maintenance haemodialysis and renal transpiantation: National survey by questionnaire: Preliminary report.

Trans. Am. Soc. Art. Intern. Organs 19 (1973) pp. 138-143 (a).

LEVY, N.B. The problems on being a patient on maintenance haemodialysis. Proceedings of the Fifth International Congress of Nephrology, S. Karger, Base 1,1973 (b).

LEVY. N.B. The psychology and care of the maintenance haemodiallysis patient.

Heart Lung: J. Crit. Care, 2 (1973) 400 (c). 


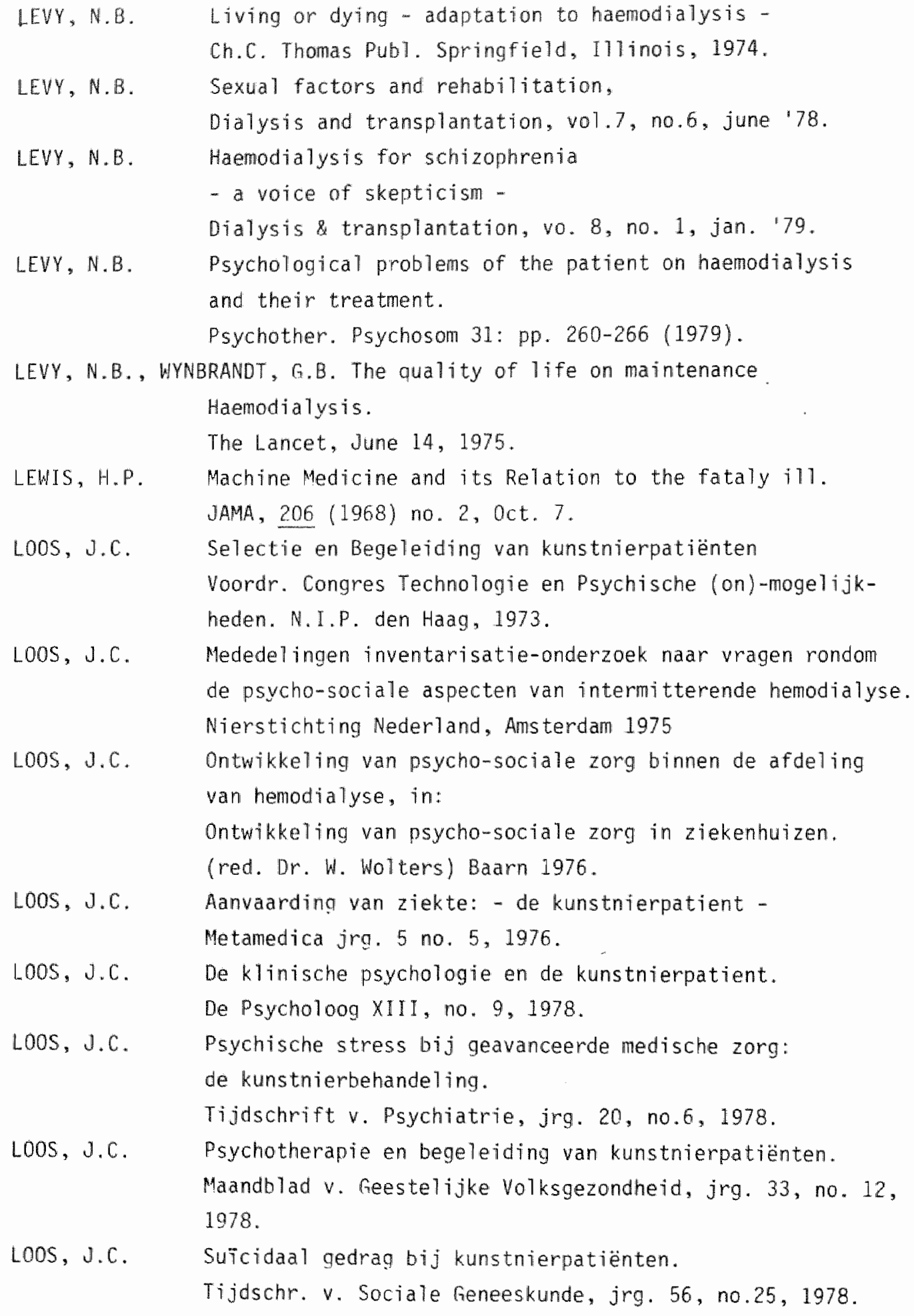


LOOS, J.C. Ziekte en Grenssituatie, Praktische Theologie. Ned. Tijdschrift w. Pastorale Wetenschappen, no. 1, 1979.

LOOS, J.C. Psychotherapie bij kunstnierpatiènten.

Ned. Tijdschrift voor Psychotherapie, jrg. 5, no.2, 1979.

LOOS, J.C., HINTZEN, A.H.J., SPORKEN C.P. Het vrijwillig beëindigen van de kunstnierbehandeling.

Ned. Tijdschr. v. Reneeskunde jrg. 123, no.32, Aug. 1979.

LOOS, J.C. Leven met de kunstnier - gesprekken met kunstnierpatiěnten -. Uitg. de Tijdstroom 1980.

LUDDY, E. Bridging the gap between dialysis and transplantation.

Dialysis and Transplantation, June/July 1973.

MACNAMARA, M. Psychological Problems in a Renal Unit.

Brit. J. Psychiat. 113 (1967) pp. 1231-1236.

MALLARD, W. Rehabilitation level of home heamodialysis patients and pre-dialysis training social factors.

Dialysis and Transplantation decemb./jan. 1977

MALMQUIST, A. A prospective study of patients in chronic haemodialysis

I. Method and characteristics of the patientgroup.

Journal of Psychosom. Research 17 (1973) pp. 333-337.(a)

MALMOUIST, A. A nrospective study of patients in chronic haemodialys is

I1. Predicting factors regarding rehabilitation.

Journal of Psychosom. Research 17 (1973) pp. 29-34 (b).

MALMOUIST, A., KOPFSTEIN, F. e.a. Factors in psychiatric prediction

of patients beginning haemodialysis: a follow-up of

13 natients.

Journal of Psychosom. Research 16 (1972) pp. 19-23.

MARBY, T., ACCHIARDO, R., TRAPP, G. Psychological aspects of dialysis from

the personel viewpoint.

Dialysis and transplantation, november 1977.

MARSHALL, J.R. Effective use of a psychiatric consultant on a dialysis unit.

Postgraduate Medicine, wo .55, no.2, febr. 1974.

MASS, M., KAPLAN DE NOUR, A. Reactions of Famillies to chronic haemodialysis

- a preliminary report -

Psychather. Psychosom. 26: 20 - 26 (1975). 
MELDRUM, M.W. e.a. The imract of chronic haemodialysis upon the sociaeconomics of a veteran patient group.

J. Chron. Dis. 21 (1968) 37.

MENZIES, I.C., STEWART, H.K. Psychiatric Observations on Patients Receiving Regular Dialysis Treatment.

British Medical Journal 1 (1968) pp. 544-547.

METZ, w. Het verschijnsel pijn, Utrecht, 1975 .

MEYLER, F.L. Apparatuur-Patiënt / Patiënt-Medicus

Med. Contact 28 (1973).

MICKLIN, C.F. Personal observations of spouse/parent groups. Dialysis \& transplantations, september 1977.

MORRIS, S. Grief and how to live with it.

Allen \& Lenwinn Ltd, London, 1971.

MEWTON, J.R., BOHNEN, A., Psychoeducational meetings with the spouses of ESRD patients.

Dialysis and transplantation, vol.7, no.6, june 1978.

NORTON, Ch.E. Attitudes toward living and dying in patients on chronic haemodialysis.

Ann. N.Y. Acad. Sci. 164 (1969) pp. 720-732.

OSGOOD, C.E., Guci, G.J., TANNENBAUM, P.H. The measurement of meaning, Cubana, 1957.

PARKES, C.M. Bereavement, studies of Grief in adult life. Internat. Inivers. Press Inc., New York, 1972.

PASTERNACK, A. Causes and duration of renal failure and duration of working disability in dialysis candidates.

Acta med. scand. 194 (1973) pp. 17-21.

PENTECOST, R.L. Family study in Home Dialysis.

Arch. Fen. Psychiat. 22 (1970) June.

PITTARD, J.R.N. Self Care dialysis.

Dialysis and Transplantation 3 (1974) no.3, Apri1/May

POKORNY, A.D. Characteristics of forty-four patients, who subsequently committed suicide.

Arch. Gen. Psychiat. 2 (1960) pp. 314-323.

PRITCHARD, $M$. Meaning of iTlness and patients" response to longterm haemodialysis.

Journal of Psychosom. Research 18, 1974, (a), p. 457. 
PRITCHARD, M. Dimension of illness behavior in long-term haemodialysis

J. of Psychosom. Research, vol. 18, 1974, pp. 351-356 (b).

PRITCHARD, M. Reactions to illness in long-term haemodialysis, J. of Psychosom. Research, vol. 18, 1974, pp. 55-67, (c.)

PRITCHARD, M. Further studies of 117 ness behavior in long-term haemodialysis. 3. of Psychosom. Research, 21 (1977) pp. 41-48.

RAIMBAULT, G. Psychological Aspects of Chronic Renal Failure and Haemodialys is. Nephron, 11, 1973, pp. 252.

RAMSAY, P. The patient as person. Yale Univ. Press, London, 1970.

RAPAFORT, F.T. A second look at life. Grune \& Stratton, New York, 1974.

RAWNSLEY, P.A. Haemodialysis: THE SOCIAL PROBLEM. Social and psychological problems in long-term treatment by haemodialysis.

Nursing Times, June 18, 1970.

REICHSMAN F., LEVY, N.B. Problems in adaptation to maintenance haemodialysis:

A four years study of 25 patients.

Arch. Int. Med. 130 (1972) p. 859.

Id.: Levy, Living and Dying, 1974.

ROODVOETS, A.P., STRUYVENBERG, A. In.: Arts en verpleegkundige in het ziekenhuis. Leiden, 1970, pp. 37-41.

ROTTER, J.B. Generalized expectancies for internal versus external control of reinforcement.

Psychol. monog. 80 (1966) pp. 1-28.

SAND, P., LIVINGSTON, WRIGHT, R.G. Psychological Assessment of Candidates for a Haemodialys is Program.

Ann. Int. Med. 64 (1966) pp. 602-610, no. 3, March.

SCHMALE, A.H. Giving up as a final common pathway to changes in health. Adv. Psychosoni. Med. 8 (1972) pp. 20-40.

SCHMECK, H.M. De artificiële mens. Walker \& Comp., New York, Ned. vert.: Het Spectrum 1970.

SCHNEEMANN, R.T. Psychosociale aspecten van de thuisdialyse. Metamedica, 50, 1971.

SCHNEEMANN, R.T. DE VRIES-DE REGT, M.L. Evaluatie onderzoek thuisdialyse. Rapport: Nierstichting Nederland, A'dam 1975.

SCHÖNBERG, B., CARR, A.C., e.a. Loss and Grief; psychoiogical management in medical practice.

Columbia Univ. Press, New York/London, 1970 (a). 
\$CHÖNBERG, B., CARR, A.C., e.a. Psychological aspects of terminal care. Columbia Univ. Press, New York/London, 1972. (b).

SCORER, G., WING, A. Decision making in medicine, London, 1975.

SCHREINER, G.E., MAHER, J.F. Haemodialys is for chronic renal failure III.

Medical, moral ethical and socio-economic problems.

Ann. Int. Med. 62 (1965) p. 551.

SCHUPAK, E., SULLIVAN, J.F. e.a. Chronic haemodialysis in "unselected"

Patients. Ann. Int. Medicine, oct. 1967, no. 4.

SCRIBNER, B.H., Inleiding in: Levy, N.B. Luving or Dyïng,

Adaptation to haemodialysis, 1974.

SHALDON, e.a. Independance Concept of Haemodialysis.

Nursing Times, 1968.

SHALDON, S. Emotional Problems in a Chronic Haemodialysis Unit.

The Lancet, December 21, 1968 (ing.st.).

SHALDON, S., e.a. Proceedings of the European Dialysis and Transplantation

Association, vol. VIII, 145, Pitman Medical, London, 1969.

SHAMBAUGH, Ph.W., KANTER, S.S. Spouses under stress: Group Meetings with

spouses of patients on haemodialysis.

Amer. J. Psychiat. 125 (1969) 7 January.

Le SHAN, L, and E. Psychotherapy and the patient with a limited life span.

In: "The phenomenon of death" ed. by $E$. Wyschogrod,

Uitg. Harper \& Row, London, 1973.

SHEA, E. BOGDAN, D.F., e.a. Haemodialysis for Chronic Renal Failure:

IV Psychological Considerations.

Ann. Int. Med. 62 (1965) pp. 558-563, no.3, March.

SHIPMAN, W.G. Shipman anxiety and depression scale, a one page of anxiety and depression scale. Psychol. Rep. 13, 1963.

SHNEIDMAN, E.S., LITMAN, R.E., FARBERON, N.L. The psychology of suicide.

Science House, New York, 1970.

SHORT, M.J., WILSON, W.P., e.a. Roles of Denial in Chronic Haemodialysis.

Arch. Gen. Psychiat. 20 (1969) pp. 433-437, April.

SMITH, E.C., MAHURKAR, S.D., MAMDANI, B.H., DUNEA, G. Diagnosing dialysis dementia.

Dialysis and transplantation, vol. 7, no.12, dec. 1978.

SöRENSEN, E.T. Group therapy in a community hospital dialysis unit.

JAMA 221 (1972) pp. 899-901. 
SPEIDEL, H., KOCH, U., BALCK, F., KNLESS, J. Problems in interaction between patients undergoing long-term haemodialys is and their partners. Psychother. Psychosom. 31: pp. 235-242 (1979).

SULLIVAN, M.F. The dialysis patient and attitudes toward work. Psychiatry in medicine, vol. 4, no.2, Spring 1973.

TAYLOR, G.J. Chronic renal failure, home dialys is and the liason psychiatrist.

C.M.A. Journal, June 24, 1972, vol. 106.

TUCKMAN, A. Brief psychotherapy and haemodialysis.

Arch. Gen. Psychiat. vol. 23, 1970.

VALEK, A., TOMASEK, R. PSychological observations on the artificial kidney unit's during dialysis treatment.

Acta Universitatis carolinae medica, vol. 16, no. 5/6, pag. 523-527, 1970.

VIEDERMAN, M. Adaptive and maladaptive regression in haemodialysis

Psychiatry, vol. 37, feb. 1974.

VISOTSKY, H.M., e.a. Coping behavior under extreme stress,

Arch. of Gen. Psychiatry, vol. 5, nov. 1961, pp. 27-52.

WARDENER, H., de Emotional problems in a chronic haemodialysis unit.

The Lancet, november 23, 1968.

WEISMAN, A.D. On Dying and Denying. New York, 1972,

Ned.vert.: "De dood nabij", uitg. Ambo, 1973.

WHATLEY, L.W. Home and Incenter haemodialysis patients.

- A sociological view -.

Dialysis and Transplantation, 1972, pp. 42-43.

WING, A.J., BRUNNER, e.a. Dialys is and transplantation in Europe.

Clinical Nephrology, 3 (1975) no.4.

WINOKLUR, M.Z., CZACZKES, J.W., KAPLAN DE NOUR, A. Intelligence and adjustment to chronic haemodialysis.

Journ. of Psychosom. Research, 17 (1973) pp. 29-34.

WRIGHT, R.G., SAND, P., LIVINGSTONE, G. Psychological Stress during Haemodialys is for Chronic Renal Failure.

Ann. Int. Med. 64 (1966) pp. 611-621, no.3, March.

WRIGHT, T. Family therapy and the nephrology patient.

Dialysis and Transplantation, Oct./Nov. 1975. 
WIJDEVELD, P., GRAEFF, J. de, STRUYVENBERG, A. De zuinigheid die de wijsheid bedriegt. Zorgen over kunstnierbehandeling en niertransplantatie.

Ned. T. Geneeskunde 119 (1975) no. 1.

WIJSENBEEK, H., MUNITZ, H. Group Treatment in a Haemodialys is Center.

Psychiat. Meuro1. Neurochir. 73 (1970) pp. 213-220. 
Bijlagen:

- 195 - 


\begin{tabular}{|c|c|c|c|c|c|}
\hline & $\mathbb{N}$ & $m / v r$ & Burg.staat & Leeft. & $\begin{array}{l}\text { Dialyseduur } \\
\text { in maanden. }\end{array}$ \\
\hline $\begin{array}{l}\text { Groep A } \\
n=10 \\
\text { spreiding: } \\
20-51 \text { jaar } \\
\text { gem.1ft.: } \\
38.2 \text { jaar }\end{array}$ & $\begin{array}{l}1 \\
2 \\
3 \\
4 \\
5 \\
6 \\
7 \\
8 \\
9 \\
10\end{array}$ & $\begin{array}{l}m \\
m \\
v r \\
v r \\
v r \\
v r \\
v r \\
m \\
v r \\
v r\end{array}$ & $\begin{array}{l}\text { ongehuwd } \\
\text { gehuwd } \\
\text { gehuwd } \\
\text { gehuwd } \\
\text { gehuwd } \\
\text { gehuwd } \\
\text { gehuwd } \\
\text { gehuwd } \\
\text { gehuwd } \\
\text { gehuwd }\end{array}$ & $\begin{array}{l}25 \\
26 \\
32 \\
20 \\
51 \\
38 \\
47 \\
50 \\
49 \\
50\end{array}$ & $\begin{array}{c}60 \\
23.5 \\
32 \\
51 \\
46 \\
14.5 \\
23.5 \\
34 \\
22 \\
9\end{array}$ \\
\hline $\begin{array}{l}\text { Groep B } \\
n=10 \\
\text { spreiding: } \\
49-68 \text { jaar } \\
\text { gem. } 1 \mathrm{ft} \text { : } \\
57.5 \text { jaar. }\end{array}$ & $\begin{array}{l}1 \\
2 \\
3 \\
4 \\
5 \\
6 \\
7 \\
8 \\
9 \\
10\end{array}$ & $\begin{array}{l}\text { min } \\
\text { mr } \\
\text { min } \\
m \\
v r \\
m \\
v r \\
m \\
v r \\
v r\end{array}$ & $\begin{array}{l}\text { gehuwd } \\
\text { gehuwd } \\
\text { ongehuwd } \\
\text { gehuwd } \\
\text { ongehuwd } \\
\text { gehuwd } \\
\text { gehuwd } \\
\text { gehuwd } \\
\text { gehuwd } \\
\text { gehuwd }\end{array}$ & $\begin{array}{l}68 \\
64 \\
64 \\
49 \\
54 \\
56 \\
53 \\
52 \\
61 \\
58\end{array}$ & $\begin{array}{c}43 \\
10.5 \\
3 \\
22.5 \\
22.5 \\
20.5 \\
17 \\
12 \\
5 \\
25\end{array}$ \\
\hline $\begin{array}{l}\text { Groep } C \\
n=10 \\
\text { spreiding: } \\
21-48 \text { jaar } \\
\frac{\text { gem. } 1 \mathrm{ft} .:}{37.6 \text { jarr }}\end{array}$ & $\begin{array}{l}1 \\
2 \\
3 \\
4 \\
5 \\
6 \\
7 \\
8 \\
9 \\
10\end{array}$ & $\begin{array}{l}v r \\
m \\
v r \\
m \\
v r \\
m \\
m \\
m \\
v r \\
v r\end{array}$ & $\begin{array}{l}\text { gehuwd } \\
\text { gehuwd } \\
\text { gehuwd } \\
\text { gehuwd } \\
\text { ongehuwd } \\
\text { ongehuwd } \\
\text { gehuwd } \\
\text { ongehuwd } \\
\text { gehuwd } \\
\text { gehuwd }\end{array}$ & $\begin{array}{l}38 \\
44^{*} \\
46^{*} \\
39 \\
30 \\
21 \\
46^{*} \\
18 \\
48^{*} \\
46\end{array}$ & $\begin{array}{c}55 \\
58 \\
52.5 \\
47.5 \\
45.5 \\
41 \\
36.5 \\
26 \\
21 \\
9\end{array}$ \\
\hline $\begin{array}{l}\text { Groep D } \\
n=10 \\
\text { spreiding: } \\
26-62 \text { jaar } \\
\text { gem. } 1 \mathrm{ft.}:\end{array}$ & $\begin{array}{l}1 \\
2 \\
3 \\
4 \\
5 \\
6 \\
7 \\
8 \\
9 \\
10\end{array}$ & $\begin{array}{l}m \\
v r \\
v r \\
m \\
m \\
v r \\
v r \\
m \\
m \\
v r\end{array}$ & $\begin{array}{l}\text { gehuwd } \\
\text { ongehuwd } \\
\text { ongehuwd } \\
\text { gehuwd } \\
\text { gehuwd } \\
\text { gehuwd } \\
\text { gehuwd } \\
\text { gehuwd } \\
\text { gehuwd } \\
\text { gehuwd }\end{array}$ & $\begin{array}{l}43 \\
29 \\
62 \\
56 \\
26 \\
41 \\
33 \\
34 \\
57 \\
41\end{array}$ & $\begin{array}{l}\text { geen gegevens bekend } \\
\text { m.b.t. tijdsduur en } \\
\text { frequentie van bestra- } \\
\text { lingstherapie. }\end{array}$ \\
\hline
\end{tabular}

* Terug op dialyse na mislukte transplantatie.

Bijlage I. Overzicht patiëntenbestand vooronderzoek. 
Bijlage Ir: Overzicht van 13 op face-value gefomeerde clusters van 57 uitspraken. 
Cluster 1. Angst voor de apparatuur.

1 - Steeds angstgevoelens hebben bij aan-of afsluiten.

47 - Angst voor de kunstnier

11 - Angst of bang zijn voor storingen in de apparatuur.

19 - De machine/kunstnier als een bedreiging ervaren.

Cluster 2. Positieve mening t.o.v. de behandeling, personeel en ziekenhuis.

53 - Vinden dat het personeel zijn best doet om je te helpen.

6 - Wardering hebben of uiten voor de arts, de verpleging, of overig personeel (in het algemeen).

2 - Het fijn winden on hier gespoeid te worden.

12 - Vinden dat iedereen probeert het ons maar de zin te maken.

\section{Cluster 3. Weerstand ten opzichte van de behandeling.}

10 - Klagen over gebrek aan accutaresse bij de behandeling.

17 - Met tegenzin steeds weer naar het ziekenhuis gaan.

39 - kritiek uiten op de behandeling (verpleegkundige, dokter etc.)

8 - Wensen dat men er nooit aan begomen was.

42 - Het gevoel hebben/uiten dat men je mar aan je lot overlaat.

13 - Uiting geven aan agressiegevoelens.

Cluster 4. Steun van en relatie tot de partner.

50 - Mijn behoefte aan sexueel contact is niet minder geworden sinds ik kunstnierpatiënt ben.

57 - Vinden dat de relatie verbeterd is.

15 - Veel steun ondervinden van man of vrouw.

35 - Niet weten wat je moest beginnen wanneer je je man of vrouw niet achter je had staan. 
26 - Het warderen dat je man of vrouw zoveel voor je over heeft of zich noet ontzeggen.

55 - Probiemen ervaren in het sexueel contact.

\section{Cluster 5. Sociaal isolement.}

34 - Geen behoefte hebben on uit te gaan (in tegenstelling tot vroeger).

44 - Het gevoel hebben dat mensen je mijoen of links laten liggen c. c. niet meer op bezoek komen.

23 - Door verlies van werk en je ziekte je collega's niet meer zien.

40 - Bang zijn om uit te gaan en daardoor aan huis gebonden.

Cluster 6. Minderwaardigheidsgevoelens.

32 - Je zeîfrespect verliezen.

48 - Je minderwardig voelen.

28 - Schamen voor je ziekte.

29 - Jezelf wardeloos winden omdat je niets meer kunt.

46 - Ervaren dat je rol is uitgespeeld of overgenomen door anderen.

Cluster 7. Verdringen, ontkennen, verzet tegen de dood lalgemeen defensieve mechanismen).

20 - Vinden dat alles goed gaat.

56 - Nooit bang zijn geweest.

30 - Zeker weten dat je straks weer "de oude" bent.

38 - Niet aan je ziekte herinnerd willen worden.

21 - De dood als mogelijkheid nooit willen aanvaarden.

36 - Niet aan de toekomst denken. 
Cluster 8. Angst voor de dood.

27 - Uiting geven aan deze angstgevoelens.

52 - De dood als bedreiging ervaren.

41 - Voortdurend in angst leven dat er iets mis gaat.

Cluster 9. Aanwarden van de dood.

24 - De dood als mogelijkheid onder ogen zien.

49 - Regelingen hebben getroffen om op alles voorbereid te zijn.

Cluster 10 . Hoop, vastklampen aan medische mogelijkheden.

5 - Hopen op een transplantatie.

45 - Hopen op medische moge? ijkheden (onder andere nieuwe vindingen).

22 - Hoop hebben dat ondanks de ziekte alles gewoon door kan gaan.

18 - Hopen op een extra leven dankzij de kunstnier.

Cluster 11 . Continuering van de behandeling.

31 - Onder alle omstandigheden willen dat de behandeling wordt voortgezet.

16 - Niet wensen dat de kunstnierbehandeling wordt gestakt ondat het geen zin meer heeft.

54 - Tot het uiterste toe willen blijven spuelen en lewen.

clluster 12. Suicidale gedachten of neigingen.

3 - Er wel eens een eind aan hebben willen maken.

33 - Vaker wensen dat het mar afgelopen was.

14 - Er serieus over hebben gedacht om de behandeling te staken door niet meer naar het ziekenhuis te komen.

7 - Je niets meer aantrekken van voorschriften en regels. 
cluster 13. Wanhoop, hopeloosheid.

51 - Er geen gat meer in zien.

43 - Je door iedereen verlaten voelen.

9 - Geen hoop meer hebben op een transplantatie.

37 - Je toekomst als hopeloos ervaren.

4 - Je wanhopig voelen door alles wat je hebt verloren.

25 - Veel last hebben van depressies. 
Bijlage III: VRAGENLIJST. 


\section{Instrukties:}

De lijst die nu voor U ligt is een zogenaande "vragenlijst".

Bij elke vraag hebt U vijf antwoordmogeiijkheden. De bedoeling is dat $U$ een kruisje zet achter een van de vijf mogelijkheden, en wel achter de regel die op U van toepassing is.

Bent $U$ bijvoorbeeld $\mathbb{1} \frac{1}{2}$ jaar kunstnierpatiënt, dan zet U een kruisje achter de kolom 1 - 2 jaar, en zo gaat $U$ verder tot $U$ klaar bent met deze vragenlijst.

Wanneer een vraag niet van toepassing is op Uw situatie of wanneer $U$ de vraag niet beantwoorden kunt, dan kunt $U$ dit aangeven achter de kolom geen mening of niet van toepassing. 
1. Hoe lang bent $U$ al kumstnierpatient?

- minder dan $\frac{1}{2}$ jaar

- jaar - 1 jaar

- 1 jaar - 2 jaar

- 2 jaar -3 jaar

- 3 jaar of langer

2. Hoe ver woont $U$ wan het ziekenhuis en de plaats war

U gespoeld wordt?

- minder dan $5 \mathrm{~km}$.

- tussen $5-10 \mathrm{~km}$.

- tussen $10-20 \mathrm{~km}$.

- tussen 20 - $30 \mathrm{~km}$.

- $30 \mathrm{~km}$. of verder

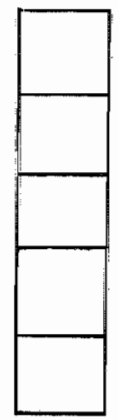

3. Hoe verplaatst $U$ zich naar het ziekenhuis en terug naar huis?

- per taxi

- openbaar vervoer

- wordt gehaald of gebracht door kenissen

of familie

- rij met andere patiënten mee

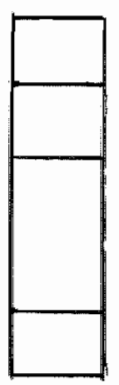

4. Hoe gat U gewoonlijk met vakantie?

- op eigen gelegenheid

- met de Nierstichting 4 daagse reizen (Italië)

- vakanties met spoelmogelijkheden

- bungallowvakanties via de Nierstichting

- ga niet (meer) met vakantie

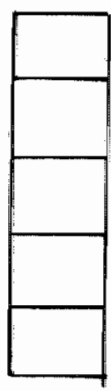


5. Hoe is Uw mening over de psychische en matschappelijke begeleiding binnen UW centrum?

- tevreden

- tamelijk tevreden

- geen mening of niet van toepassing

- tamelijk ontevreden

- ontevreden

6. Kunt $U$ in volgorde van belangrijkheid aangeven wat $U$ van deze psychosociale begeleiding verwacht? (Wat $U$ het meest belangrijk windt geeft $U$ het cijfer 1 , vervolgens een 2 enz.).

- hulp en ondersteuning via gesprekken

- bemiddelen biji en zorgen voor b.v. gezinszorg, huisvesting, andere woning

- materiële hulpverlening regelen via bedrijfsverenigingen, andere uitkerende instanties of Nierstichting

- begeleiden van het gezin (thuis)

- informatie geven over de psychosociale kanten van de kunstnierbehandeling

7. Wat is Uw mening over de medische en verpleegkundige behandeling binnen Uw centrum?

- tevreden

- tamelijk tevreden

- geen mening

- tamelijk ontevreden

- ontevreden

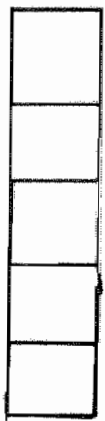


8. Kunt $U$ aangeven of en in welke mate $U$ steun en begrip ondervindt van Uw man/vrouw of partner?

- ik heb erg veel steun van mijn man/vrouw of partner

- ik heb tamelijk veel steum van mijn man/vrouw of partmer

- ik weet het niet, ik heb er geen mening over

- ik heb tamelijk weinig steun van mijn man/vrouw of partner

- ik heb helemal geen steun van mijn man/vrouw of partner

9. Werkt U momenteel?

- ik werk volledig

- ik werk gedeeltelijk

- ik werk niet meer (WAO, AWW of andere uitkering)

- ik doe volledig de huishouding

- ik doe gedeeltelijk mijn huishouding maar heb hierbij wel hulp nodig

10. Bent U door uw ziekte en de kunstnierbehandeling geĩsoleerd geraakt van vrienden of kennissen?

- volledig

- enigszins

- niet van toepassing of geen verschil met de periode voor mijn ziekte

- weinig

- helemaa 1 niet 
11. Bent $U$ zich als kunstnierpatiënt minderwardig gaan voelen?

- erg minderwardig

- tame i ijk minderwaardig

- ik weet het niet

- nauwelijks minderwaardig

- helemal niet minderwardig

12. Hoe ziet $U$ de toekomst tegemoet?

- optimistisch

- tamelijk optimistisch

- ik weet het niet

- tamelijk pessimistisch

- pessimistisch

13. Hoe stat $U$ t.a.v. een eventuele dood?

- ik ben er voortdurend bang voor

- ik ben er soms bang voor

- ik denk er niet over na of heb er geen mening over

- ik ben er niet zo bang voor

- ik theb me er helema 1 mee verzoend

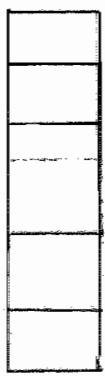

14. Verwacht $U$ zelf mee te maken dat door de verdere medischtechnische ontwikkeling de kunstnierbehandeling sterk vereenvoudigd wordt?

- ik verwacht dat zeker

- ik verwacht dat wel enigszins

- ik heb er geen mening over

- ik verwacht het nauwellijks

- ik verwacht het helemal niet

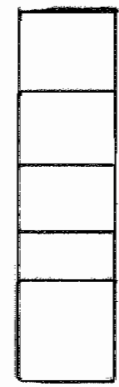


15. Ik welke mate heeft de kunstnierbehandeling Uw leven veranderd?

- ingrijpend

- enigszins

- ik weet het niet

- nauwelijks

- helemal niet

16. Binnen welke termijn verwachtte $U$ getransplanteerd te worden toen $U$ werd aangesloten op de kunstnier?

- binnen jar

- binnen 2 jaar

- ik weet het niet

- binnen 3 jar

- 3 jaar of llanger

17. Hoe zeker bent $U$ van een transplantatie?

- ik reken er zeker op

- ik hoop het maar weet het niet zeker

- ik betwijfel het, ik weet het niet

- lik heb er nauwelijks hoop op

- ik reken er niet (meer) op

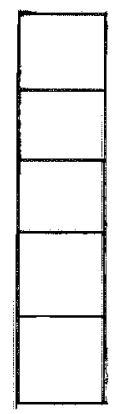


18. Hoe stat $U$ tegenover een eventuele transplantatie?

- ik verwacht er alles van

- ik sta er niet zo optimistisch tegenover

- ik weet (nog) niet of ik wel getransplanteerd wil worden

- ik geeft de voorkeur aan verder dialyseren boven een transplantatie

- ik kom niet (meer) voor een transplantatie in aanmerking

19. Hebt $U$ er wel eens serieus over nagedacht om met de behandeling te stoppen ondat $U$ er geen heil meer in zag?

- vaak

- soms

- ik weet het niet

- zelden

- nooit

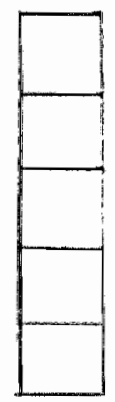


Bijlage IV: UITSPRAKENLIJST. 


\section{Instructie.}

Op bijgaand formulier staan een aantal uitspraken vermeld van kunstnierpatiënten.

De vraag aan $u$ is of $u$ door het zetten van een kruis $(x)$ wilt aangeven of u het met deze uitspraken al of niet eens bent.

U hebt hierbij 5 mogelijkheden.

Bent $u$ het eens met een uitspraak, dan zet $u$ het kruis $(\mathrm{X})$ onder de kollom : wel mee eens (1)

Hebt $u$ er geen mening over, dan geeft $u$ dit aan op dezelfde wijze onder de kolom: geen mening of niet van toepassing (3) Bent $u$ het met een uitspraak niet cens, dan zet $u$ een kruis $(x)$ onder de kolom : niet mee eens (5)

U kunt ook gebruik maken van kolom 2, dit betekent tamelijk mee eens of kolom 4, wat betekent niet geheel mee eens.

\section{Er zijn dus in totaal 5 antwoordmogelijkheden:}

Wel mee eens $=1$

Tanelijk mee eens $=2$

Geen mening of niet van toepassing $=3$

Niet geheel mee eens $=4$

Niet mee eens $=5$

Kijkt u wanneer u met deze uitsprakenlijst klaax bent nog even na of u niets vergeten bent. 
1. Bij aan- en afsluiten op de kunstuier ben ik steols bang

2. Ik vind het fijn on met de kunstnier behandeld te kunen worden.

3. Ik heb er wel eens emstig over nagedacht on met spoelen te stoppen.

4. Ik voel me warhopig on alles wat er voor mij verloren is gegaan.

5. Ik hoop getransplanteerd te worden.

6. Voor diegenen die bij mijn behandeling betrokken zijn heb ik veel waardering.

7. Ik trek me niet veel aan van dieeten vochtbeperking.

8. Ik wou dat ik noojt met spoelen begonnen was.

9. Ik hel geen hoop meer om voor een transplantatie in aamexking te komen.

10. Ik word niet zorgvuldig genoeg behandeld.

11. rk ben bang voor storingen in de apparatuur.

12. Tk vind dat ledereen probeert het mij naar de zin te maken.

13. Als ik kwaad ben laat ik het good merken.

14. Ik heb er wel eens ernstig over gedacht un met de bejandeling op te houden.

15. Ik heb veel steun aan mijn man/vrouw.

16. Warneer mijn toestand slecht wordt en de dokter ex geen heil. meer in ziet zou ik toch niet willen ophouden met spoelen.

17. Ik ga steeds met tegenzin naar het ziekenhuis on gespoeld te worden. 
18. Ik heb een goede hoop on dankzij de kunstnier nog lang te kumen leven.

19. Met de kunstnier raak ik nooit vertrouwd.

20. Ik vind dat alles goed gaat.

21. De dood speelt voor mij geen enkele rol.

22. Ik wil dat ondanks rijin ziekte alles gewoon door kan gaan.

23. Door mijn ziekte raak ik steeds meer geisoleerd van vrienden en collega's.

24. Als kunstnierpatiënt moet ik zeker de dood onder ogen kunnen zien.

25. Ik heb vaak last van depressies.

26. Ik ervaar dat mijn man/vrouw zich voor mij veel moet ontzeggen.

27. Als ik bang ben laat ik het heus wel merken.

28. Ik heb ex geen moeite mee om aan de mensen te vertellen wat ik mankeer.

29. Hoe minder ik kan hoe waardelozer ik me voel.

30. Ik stel me voor dat ik, als ik getransplanteerd ben, weer de oude word.

31. Onder alle onstandigheden will ik met spoelen doorgaan.

32. Langzamerhand verlies ik mijn gevoel van eigenwaarde.

33. Soms zou ik willen dat het maar afgelopen was met mij. 
34. Ik heb weinig behoeft meer on uit

$\begin{array}{lllll}1 & 2 & 3 & 4 & 5\end{array}$
te gaan.

35. Ik zou niet weten wat ik moest be ginnen als mijn man/vrouw niet achter me had gestaan.

36. Ik denk niet aan de toekonst.

37. Ik voel me hopeloos ais ik aan de toekonst denk.

38. Ik wil niet aan mijn ziekte herinnerd worden door anderen.

39. Ik ben niet tevreden over de wijze waarop ik als patiënt behandeld wordt.

40. Door mijn ziekte ben ik steeds meer aan huis gebonden.

41. Ik ben vaak bang dat er iets mis gaat tijdens het spoelen.

42. Tijjdens het spoelen heb ik het gevoel dat ik ejgenlijk aan mijn lot wordt overgelaten.

43. Ik voel me door iedercen verlaten.

44. Tk heb het gevoel dat als je kumstnferpatiënt bent de mensen je steods meer gaan mijiden.

45. Ik heb hoop dat de toekomst voor mij als kunstnierpatiënt steeds beter wordt door de vooruitgang van de medische wetenschap.

46. Ik vind dat mijn functie binnen het gezin steeds meer wordt overgenomen door anderen. 
47. Ik ben bang voor de kunstrier.

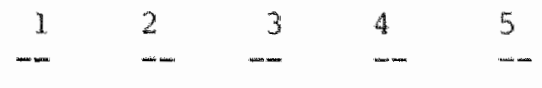

48. Ik voel me steeds meer minderwaardig.

49. Ik heb regelingen getroffen om op alles voorbereid te zijn.

50. Mijn behoefte aan sexueel contact is niet minder geworden sinds ik kunstnierpatiënt ben.

51. Ik zie er geen gat meer in.

52. De dood ervaar ik niet als een bedreiging.

53. Ik vind dat het afdelingspersoneel zijn best doet on je te helpen met alles.

54. Ik wil tot het uiterste blijven spoelen.

55. Sinds ik kunstnierpatiënt ben ervaar ik moeili.jkheden in het sexuele contact.

56. Mijn ziekte heeft mij weinig angst bezorga.

57. Ik vind dat de relatie tot mijn man/ vroum door mijn ziekte is verbeterd. 
Bijlage V: Voorbeeld van semantische differential. 
Instructie:

In dit deel van het onderzoek wordt aan $U$ gevraagd de betekenis van bepaalde ideeën aan te geven op een schaal die twee uitersten kent.

Hier ziet U een voorbeeld van zo'n schaal:

goed -.- -.- -.- -.- -.- slecht.

De uitersten van deze schal worden gevormd door woorden of termen die tegenstellingen zijn (b.v. goed -- -- - - - - slecht). Zo is het mogelijk om aan te geven waar een bepaald idee U aan doet denken, b.v. "ziekenhuis" of "dialyse-afdeling".

U kunt dit aangeven in termen van goed of slecht, mooi - lejijk, opgewekt - teneergeslagen etc..

Wanneer het ziekenhuis voor U "slechte" gevoelens oproept, kunt $U$ dit aangeven door een $X$ te zetten rechts op de schaal die loopt van goed naar slecht. U doet dit zo: goed -... -... -... -... - -

Maar er zijn meer mogelijkheden die liggen tussen goed en slecht, daarom gebruiken we hier schalen met vijf mogelifkheden. Uw ervaringen met het ziekenhuis of andere begrippen kunnen $n$. ook tamelijk slecht of tamelijk goed zijn. Ook dit kunt U op de schaal aangeven door een $X$ te zetten bij:

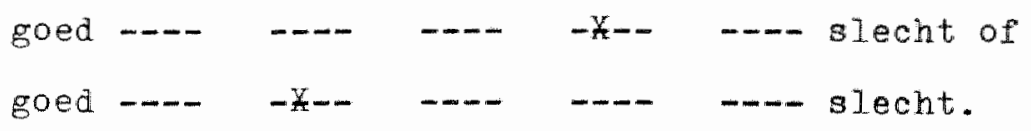


Wanneer $U$ de ideeën die $U$ op de komende bladzijden bovenaan even goed als slecht vindt of niet thuis kunt brengen op de aangegeven schaalwaarden van goed -.--- slecht, mooi -..-- lelijk, snel ----- langzaam etc., dan zet $U$ een $X$ in het midden van de schaal d.w.z. niet goed of slecht, niet mooi of lelijk enz. enz..

Op elke pagina ziet U links bovenaan het te beoordelen idee staan, met daaronder de schalen ran het ene uiterste naar het andere.

De bedoeling is dat $U$ elk idee een plaats geeft op elke schaa].

Denk er niet te lang over na. Het gaat om Uw eerste indruk.

- Zet de kruisjes op de strepen.

- Sla niets over.

- Zet nooit meer dan één kruisje op een streep.

- Succes ermee! 


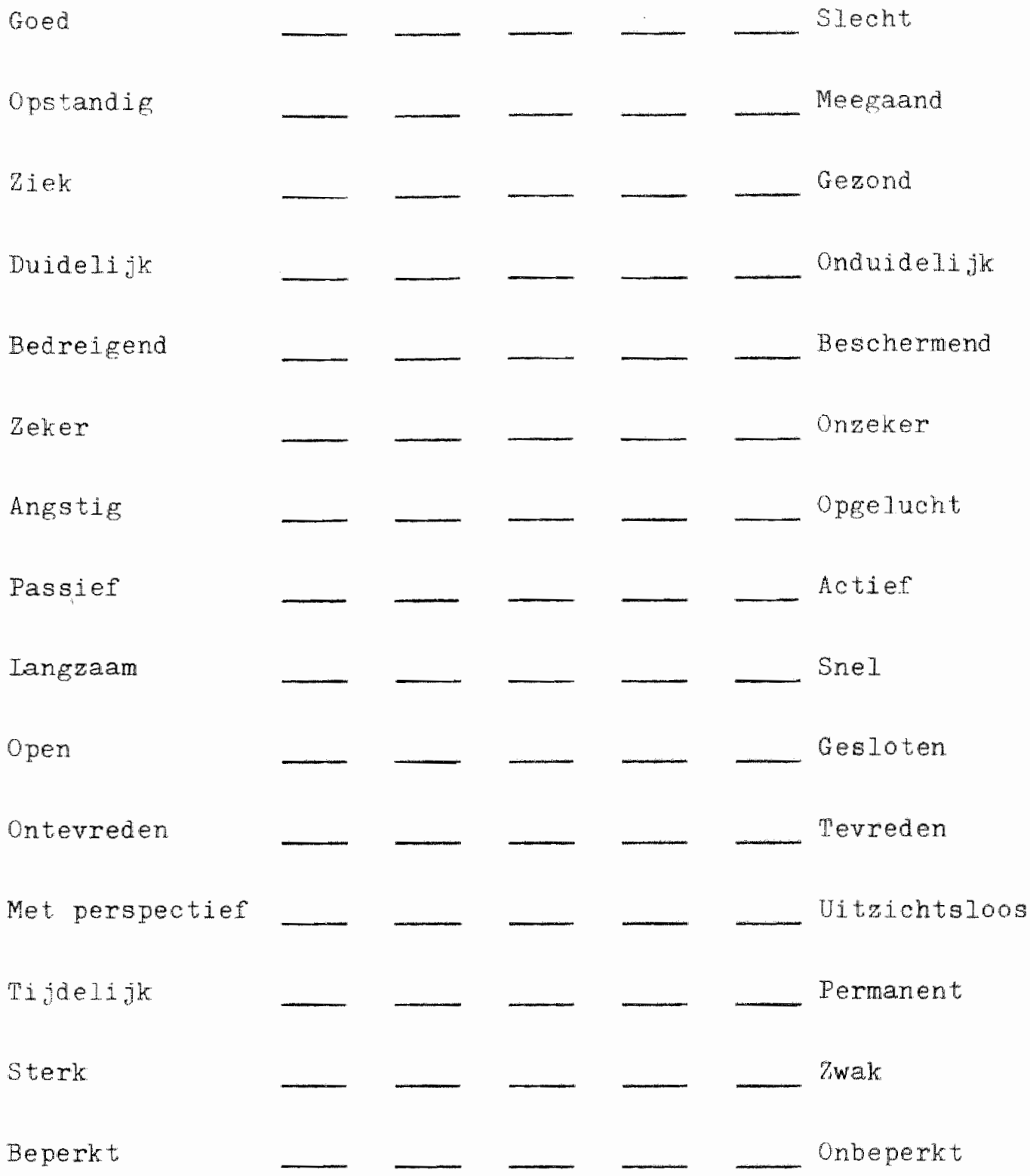


Biflage VI.

Variantieanalyse met betrekking tot de vragenlijst. 
$\begin{array}{cc}\dot{8} & 8 \\ 8 & 9\end{array}$

i. $\vec{m}$

$\stackrel{8}{2}$

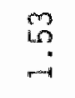

$\underset{\infty}{\infty}$

8

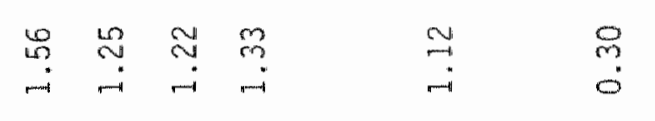

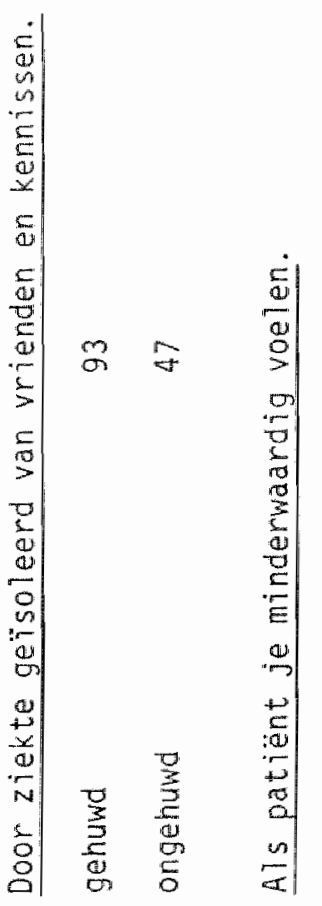

त $m \underset{n}{m}$

$m \quad \infty$

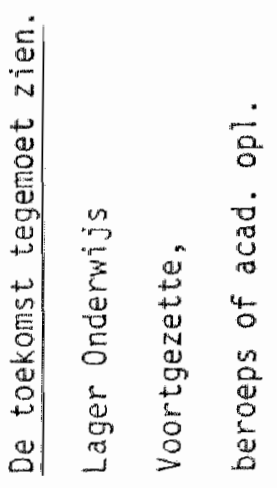


8
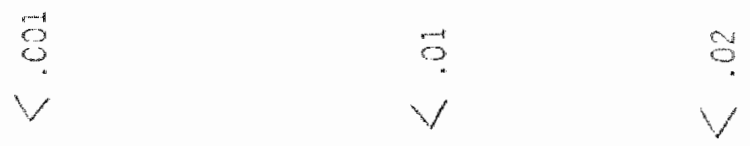

$\stackrel{\leftrightarrow}{a}$

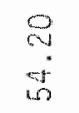

$$
\stackrel{m}{n}
$$

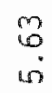

$\begin{array}{lll}9 & 8 & 9 \\ -1 & 0 & -1\end{array}$

40
0

in 8 m

$\stackrel{\infty}{-\infty}$

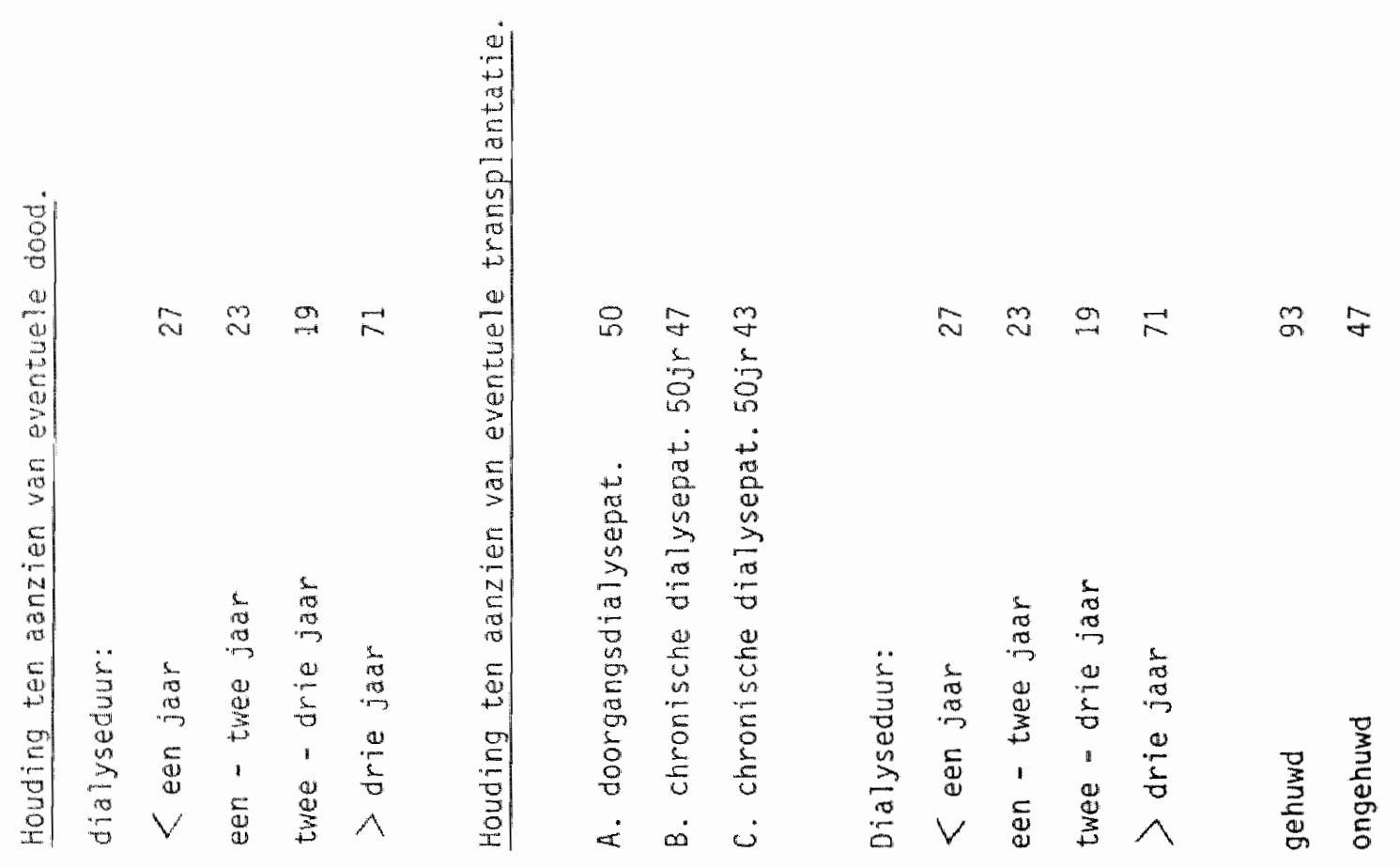


ta.

$\infty$
0
0

$\begin{array}{llll}\text { in } & 0 & g & m \\ -i & - & -\end{array}$

$m \stackrel{m}{m}$

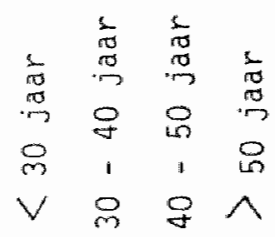


BIJLAOE VII:

Univariate variantieandyse met betrekking tot de uitsprakenlijst. 


\begin{tabular}{|c|c|c|c|c|c|c|c|}
\hline Cluster & Groepen & Gerriddelese & St. Ong. & Yartantie & $N_{1}$ & $F$ & P. \\
\hline \multirow[t]{3}{*}{ 1. Angst $v . d$, kunstnier } & doorgangsdidyse & 16.2200 & 7.9650 & 15,5529 & 50 & & \\
\hline & chron. diallyse $50 \mathrm{jr}$. & 15.6522 & 4. 8406 & 23.4319 & 46 & 0.213 & $<90$ \\
\hline & chron. dialyse $<50 \mathrm{jr}$. & 16.0741 & 4.1596 & 17.3020 & 27 & & \\
\hline \multirow{3}{*}{$\begin{array}{l}\text { 2. Positieve mening t.a.x. } \\
\text { behandeling en personen }\end{array}$} & doorgangstialyse & 7.3000 & 2.8661 & 8.2143 & 50 & & \\
\hline & chron. diallyse $>50 \mathrm{jr}$ & 6.5870 & 2.4996 & 6.2478 & 46 & 1.258 & $<.30$ \\
\hline & chron. dialyse $<50$ jr. & 7.5180 & 2.8605 & 8.1923 & 27 & & \\
\hline \multirow{3}{*}{$\begin{array}{l}\text { 3. Weerstand t.a.v. } \\
\text { behandeling en personen }\end{array}$} & doorgangsdialyse & 23.8000 & 4.2666 & 18.2041 & 50 & & \\
\hline & chron. didyse $>50 \mathrm{jr}$. & 24.1304 & 5.4716 & 29.9392 & 46 & 0.057 & $<.78$ \\
\hline & chron. dialyse $<\mathrm{soj} \mathrm{jr}$. & 23.9630 & 4.5360 & 20.5765 & 27 & & \\
\hline \multirow[t]{3}{*}{ 4. Steun w.d. partner } & doorangsidialyse & 13.4857 & 4.1612 & 17.3160 & 35 & & \\
\hline & chrom. diklyse > $50 \mathrm{jr}$. & 13.4000 & 4.0051 & 16.0410 & 10 & 0.135 & $<.90$ \\
\hline & chron. dislyse $<50 \mathrm{jr}$. & 12.8667 & 3.3586 & 11.2667 & 15 & & \\
\hline \multirow[t]{3}{*}{ 5. Socianl isolement } & doorgengsdialyse & 14.1400 & 4.9722 & $20,000 \%$ & 50 & & \\
\hline & chrom dialyse > ro ju. & 13.7609 & 4.6293 & 21.2304 & 46 & 0.370 & $<.70$ \\
\hline & chron. dialyse $<50 \mathrm{sr}$. & 13.1552 & 5.0233 & 25.2336 & 27 & & \\
\hline \multirow{3}{*}{$\begin{array}{l}\text { 6. Minderwardigheids- } \\
\text { gevoel }\end{array}$} & doorgengstialyse & 17.3800 & 5.2792 & 27.9791 & 50 & & \\
\hline & chron. dialyse $>50 \mathrm{jr}$. & 18.6309 & 5,5472 & 30.7715 & $n$ & 0.3638 & $<+55$ \\
\hline & chron. dialyse<so ir. & $18.185 ?$ & 5,7314 & 32.9490 & 27 & & \\
\hline \multirow{3}{*}{ 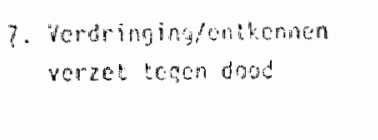 } & doongangsdidyse & 15.2800 & 3.3199 & 11.0220 & 50 & & \\
\hline & chron. thalyse $>50 \mathrm{jr}$. & $14.7: 74$ & 3.4930 & 12.2072 & 19 & $0 . \hat{2} 2 n$ & $<.70$ \\
\hline & chon. dialyse $<50$ jr. & 15.3333 & 3.1933 & 10.8462 & $2 ?$ & & \\
\hline \multirow[t]{3}{*}{ 8. Mngst woor de dood } & doomangudialyse & 9.4400 & 2.4674 & 6.0482 & 50 & & \\
\hline & chron. dialyse > so jr. & 9.5870 & 2.5793 & 6.6713 & 46 & 0.939 & 5.40 \\
\hline & chron. disalyse $60 \mathrm{jr}$. & 8.7778 & 2.4703 & 6.1086 & 27 & & \\
\hline \multirow[t]{3}{*}{ 9. Henvadien wan do dood } & dooraugstialyse & 5.9200 & 2.3197 & 5.3812 & 50 & & \\
\hline & chron. dialyse, $50 \mathrm{jr}$. & 5.08970 & 2.0958 & 4.3923 & 46 & 2.510 & $<.10$ \\
\hline & chron. dialysc $<50$ jr. & 4.9630 & 1.8999 & 3.5755 & 27 & & \\
\hline \multirow{3}{*}{$\begin{array}{l}\text { 10. Hoon, vastkiampen aan } \\
\text { redische mogol ijkhadem }\end{array}$} & doorgangsidlyse & 5.5000 & 2.0623 & $4.25 s_{1}$ & 50 & & \\
\hline & chron. dialysa: $50 \mathrm{jr}$. & 8.1087 & 3.0128 & 9.0768 & 46 & 11. $695^{\circ}$ & $<.001$ \\
\hline & chron. dialyos $<50 \mathrm{jr}$. & 6.1037 & 2.2123 & 7.9008 & 27 & & \\
\hline \multirow{3}{*}{$\begin{array}{l}\text { 11. Contimueren van die } \\
\text { bonamenting }\end{array}$} & doorgangsdialyse & 7.2200 & $3.83 \% \mathrm{~g}$ & 14.7057 & 50 & & \\
\hline & 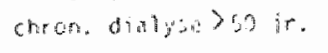 & 5.7826 & 3.000 & 9.517 & af & 7.109 & $r .19$ \\
\hline & chron dialyen $<$ ofr. & $6.255^{3}$ & 3.2177 & 10.3533 & 27 & & \\
\hline \multirow{3}{*}{$\begin{array}{l}\text { 12. Suicide gedanten } \\
\text { of neighngon }\end{array}$} & 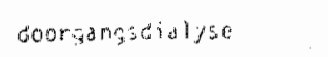 & 45.8200 & 3. $\operatorname{agg} 2$ & 1.5 .0057 & 50 & & \\
\hline & chron. dialyse $>50 \mathrm{sr}$ & 16.9201 & $3.725 \%$ & 13.2302 & $4 G$ & 0.032 & $<.00$ \\
\hline & chron. dialyse <en jr. & 17.0370 & 3. $\operatorname{gag} 7 \%$ & 15.1140 & 27 & . & \\
\hline \multirow[t]{3}{*}{ 13. Hemhoophometcosher id } & dooryangaduse & 84.7000 & 5,6709 & 29.9302 & 50 & & \\
\hline & chrom dislyen so jo. & 21.0319 & 9.0203 & $34.2: 400$ & 96 & 5.097 & $\therefore .01$ \\
\hline & chron, ar alyce<s sh. & $23.1 \% \%$ & 5.837 & 34.611 .2 & $\eta$ & & \\
\hline
\end{tabular}


BIJLAGE WIII:

Factor-analyse op de uitspraken van de witsprakenlijst. 


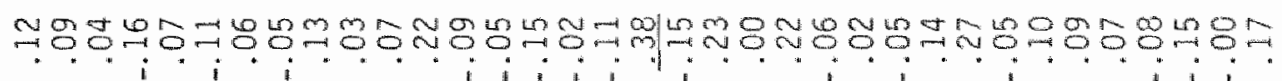

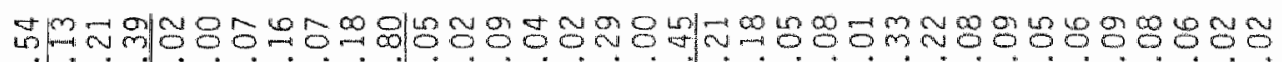

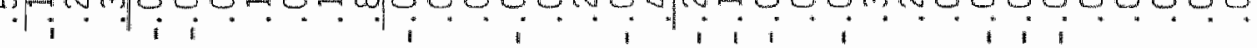

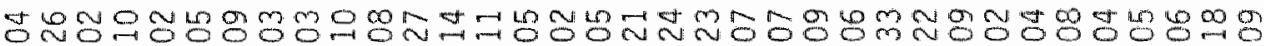

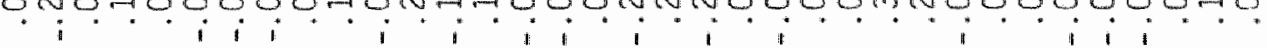

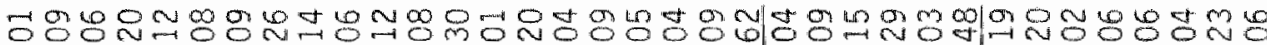

$i_{i} i$.... $i_{i} i_{i} i_{i} i_{i}{ }_{i}$.

gom .

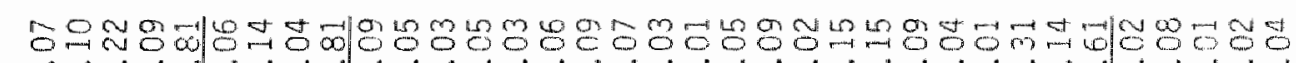

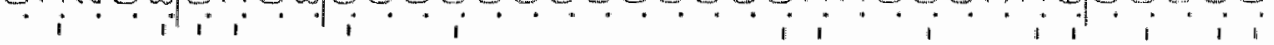

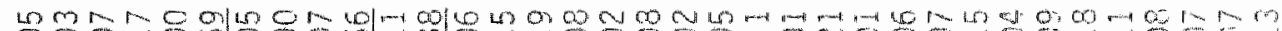

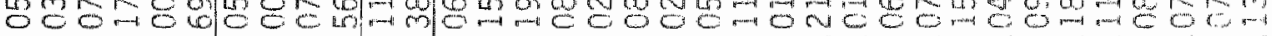

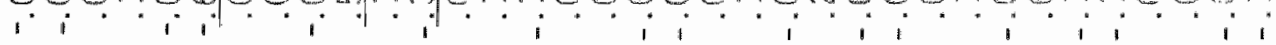

beg-wm

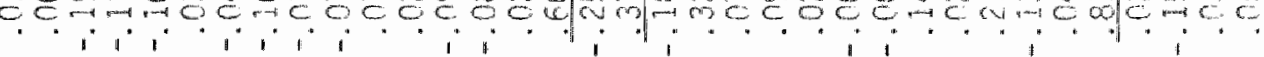

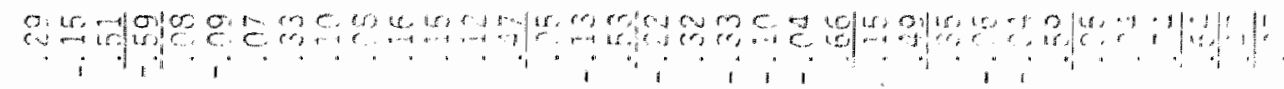

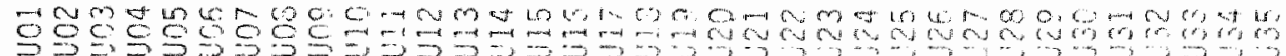




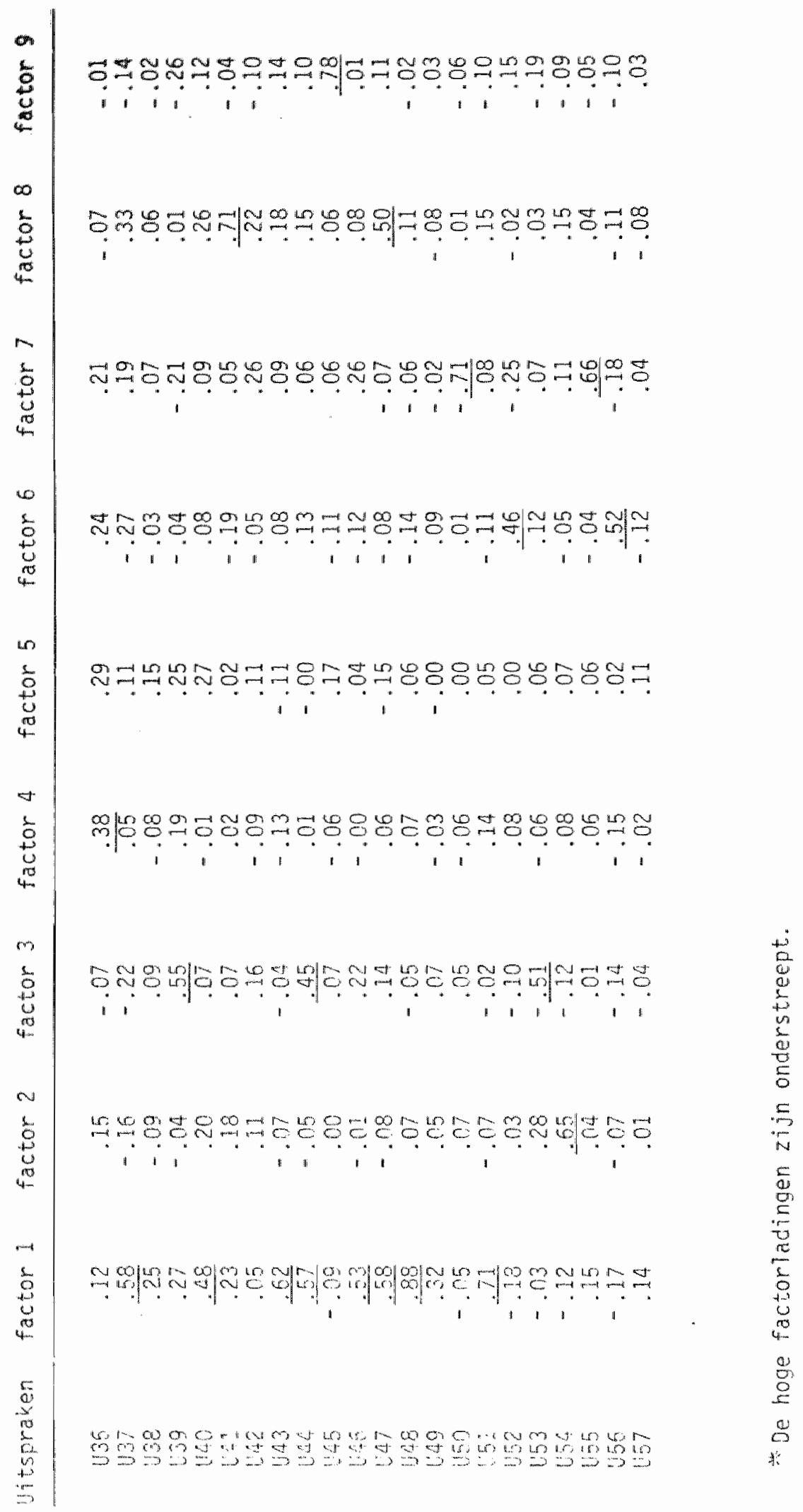


BIJLAGE IX:

Factorladingen der contrastparen na varimaxrotatie. 


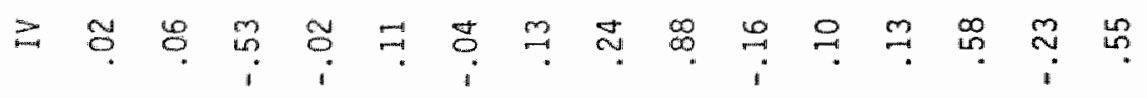

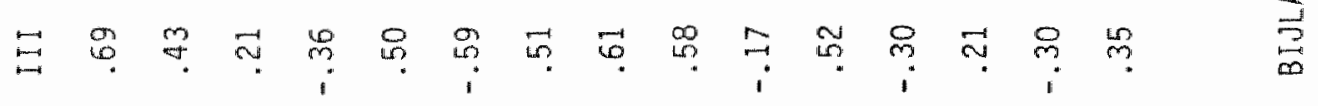

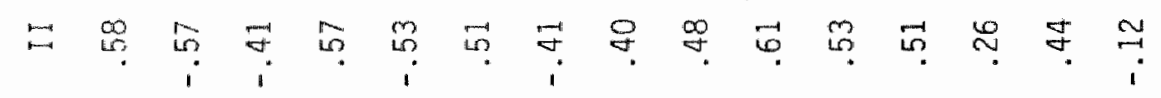

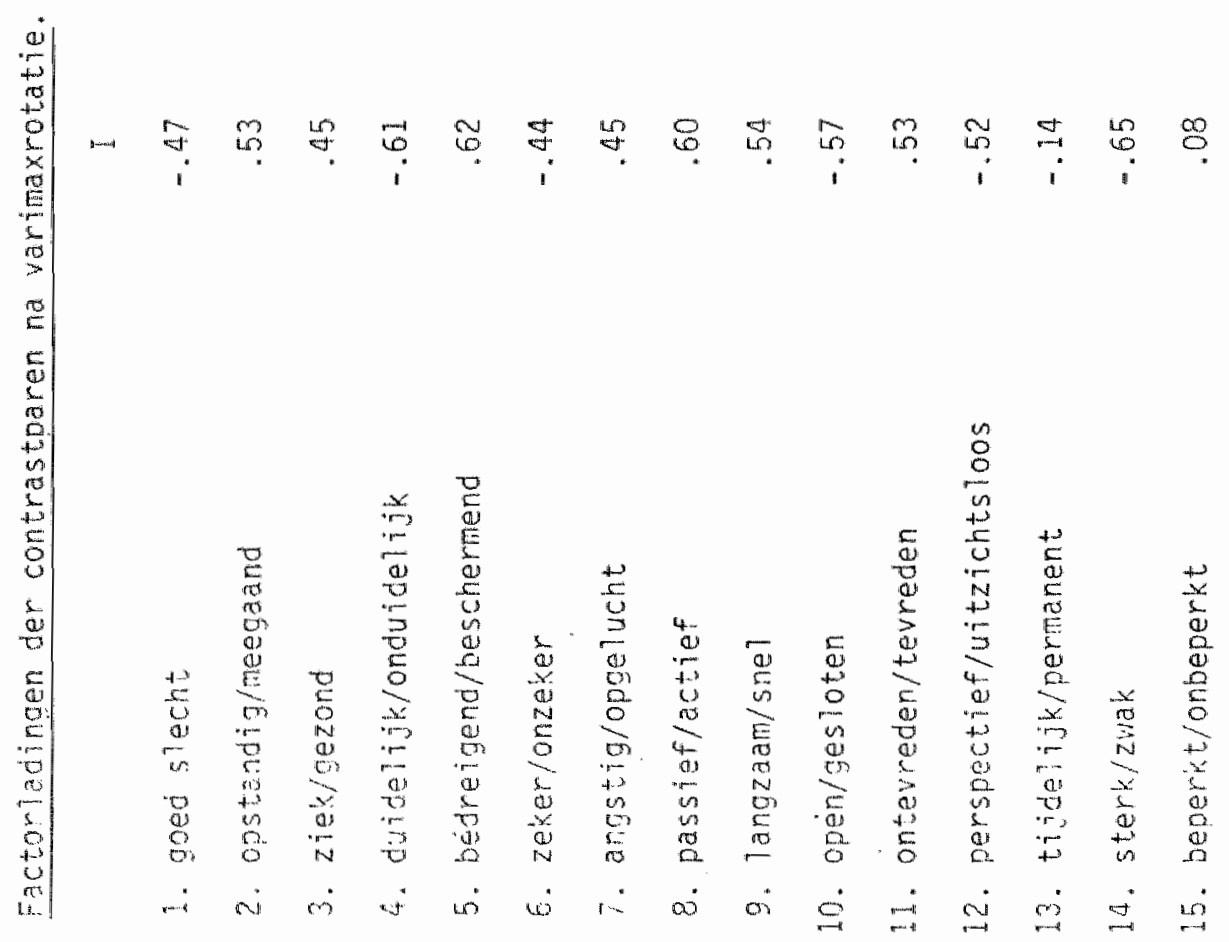


BIJLAGE $X$ :

Ladingen der contrastparen op de diverse factoren. 
Ladingen der contrastparen op de diverse factoren.

Instituten.

Factor I Factor II Factor III Factor IV

1.00

.80

$.70 \quad$ sterk

.60 perspectiof

goed

zeker

duidelijk

.50

snell

actief

open beschermend

tevreden meegaand

.40

zeker

opgelucht

tevreden

open

meegaand

beschermend

perangent

onberert?

tevrodern

geopint

.30 


\section{Personen}

Factor I

1.00

.80

meegaand

beschermend

.70

.60

.50

.40

.30 actief gezond

opge licht snel

tevreden

goed

open

zeker

anbepertit
Factor II

Factor III

Factor IV

$\begin{array}{ll}\text { open } & \text { snel } \\ \text { duidelitk } & \text { tevreden } \\ \text { goed } & \\ \text { perspectiof } & \\ & \text { actief } \\ & \text { open } \\ & \text { zeker }\end{array}$

zeker orbenon! 1 opegeluch actief 
Factor I

Factor II

1.00

.80

.70

actief

.60

open

sterk

.50

.40

.30 opgelucht

gezond zeker perspectief snel

duidelijk

tevreden goed

meegaand

tevreden

open

sterk opgelucht

zeker
Factor III

Factor IV

permanent

beschermend

perspectief

duivelijk

gezond sne 1

beschermend

opgelucht

zeker

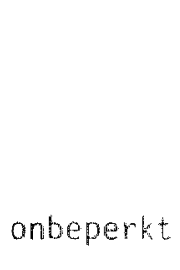


BIJLAGE XI:

Gemiddelde scores van 97 respondenten voor de vier begrippen op de respectieve dimensies/factoren: waarde, intensiteit, activiteit, gezondheidsbeleving. 
Gemiddeide scores van 97 respondenten voor de vier begrippen op de respectieve dimensies/factoren: waarde, intensiteit, activiteit, gezondheidsbeleving.

Gem. scores Factor I Factor II Factor III. Factor IV.

Dokter

Kunstmierafd. Kunstnierafd. Ziekenhuis

Dokter

Kunstnier

Ziekenhuis

Dialyseren

310

Ziekenhuis

Kunstriter

Dokter Kunstnierafd. kunstmier Verpleging Dialyseren

Verplering

Verpleaina

Dialyscron

270

oialyseren

260

Kunstnierafd.

Kunstnier

Dokter

ziexonhuis 
Bijlage xII correlatiematrix:

- Vragentijst

- Vitsprakenlijst

- Semantische differential 
Verklaring van afkortingen-

- Semantische differentiaal:

Z.H. - het ziekenhuis

K. afd. - de kunstnierafdeling

M/Vr. - mijn man/vrouw

Dokt. - de dokter

Verpl. - de verpleging

K.n. - de kunstnier

Getr.w. - getransplanteerd worden

Werk - aan het werk bi ijven

sterv. - sterven

Dial. - dialyseren

Uitspraken (cluster) lijst.

c1. 1 angst voor de kunstnier

"2 posit. mening t.a.v. behandeling

" 3 weerstand tegen behandeling

" 4 steun van de partner

" 5 sociaal isolement.

" 6 minderwardigheinsgevoel

" 7 verdringen (ontkennen) verzet

" 8 angst voor de dood

* 9 aanvarden van de dood

" 10 hoop

" 11 continueren vam behandeling

" 12 suicidale wensen / ged.

" 13 wanhoop 
Vragenlijst

$\checkmark 05$ Psychische en matsch. begeleiding

$\checkmark 08$ Mate van steun van de partner

$\checkmark 10$ Social isolement

$\checkmark$ Il Minderwardigheids gevoelens

V 12 Toekomstwerwachting

$\checkmark 13$ Houding t.a.v. de dood

* 15 Verandering vam leven

V 16 Transplantatieverwachting

$\checkmark 19$ Beëindiging van behandeling 


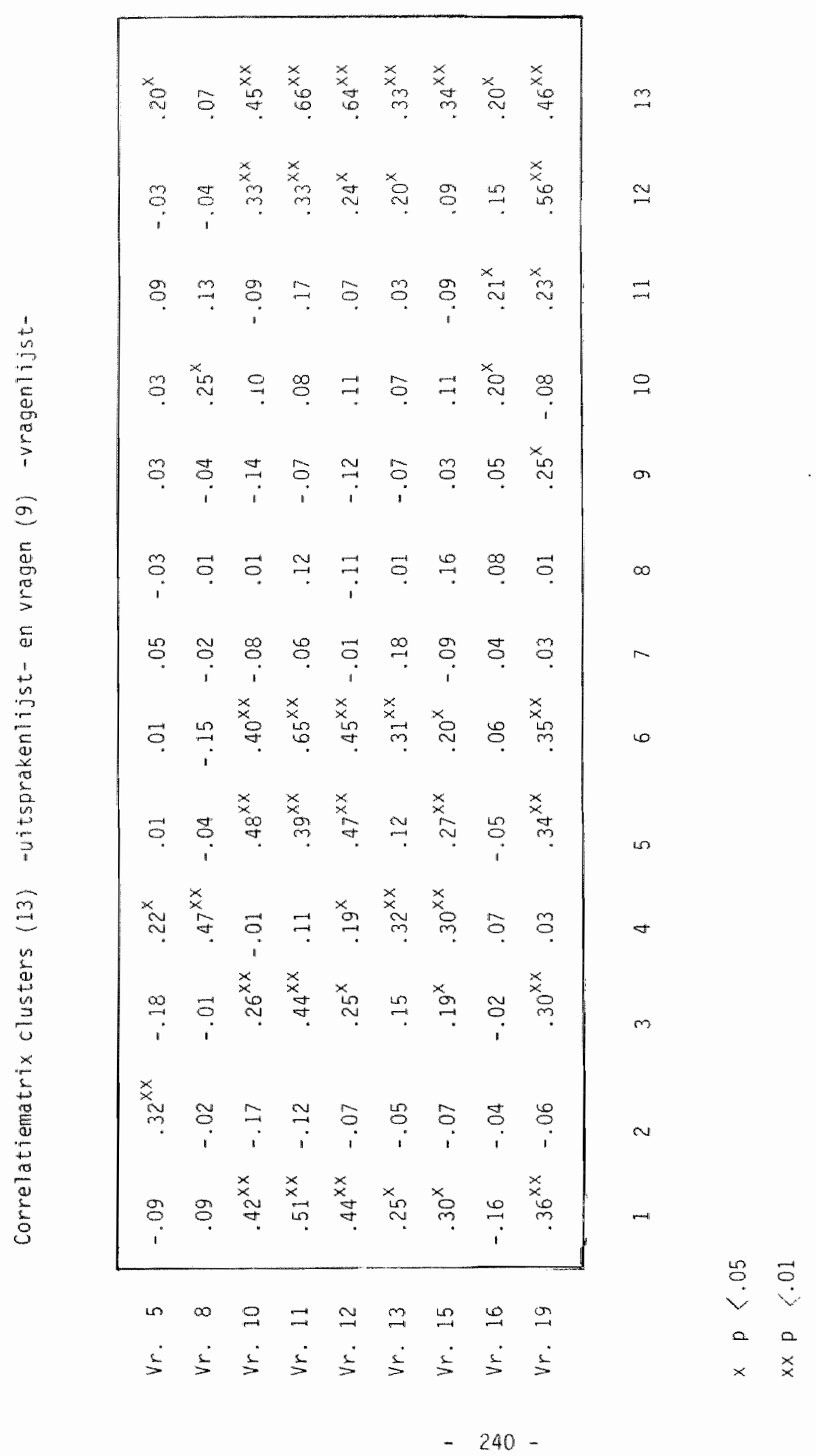



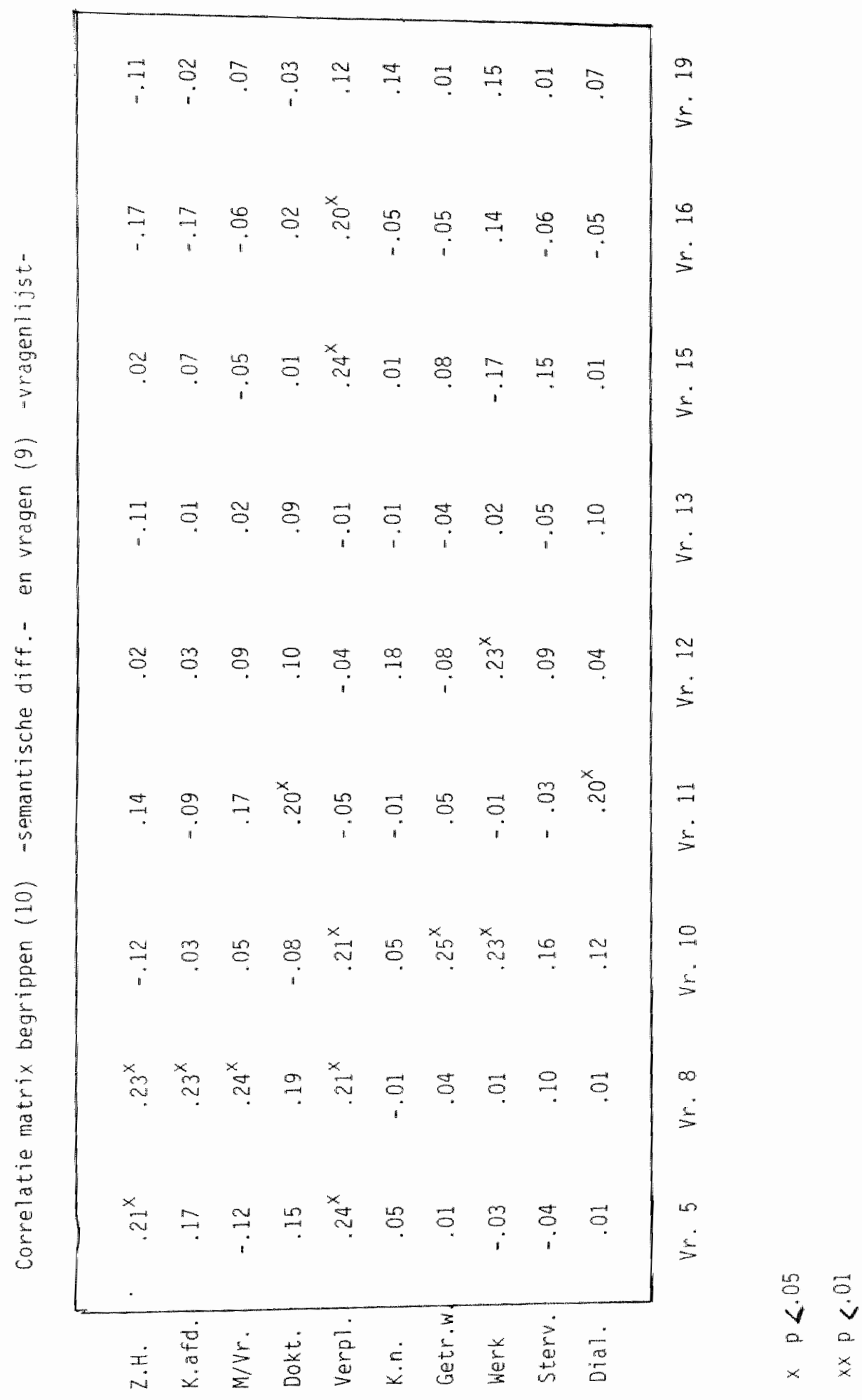


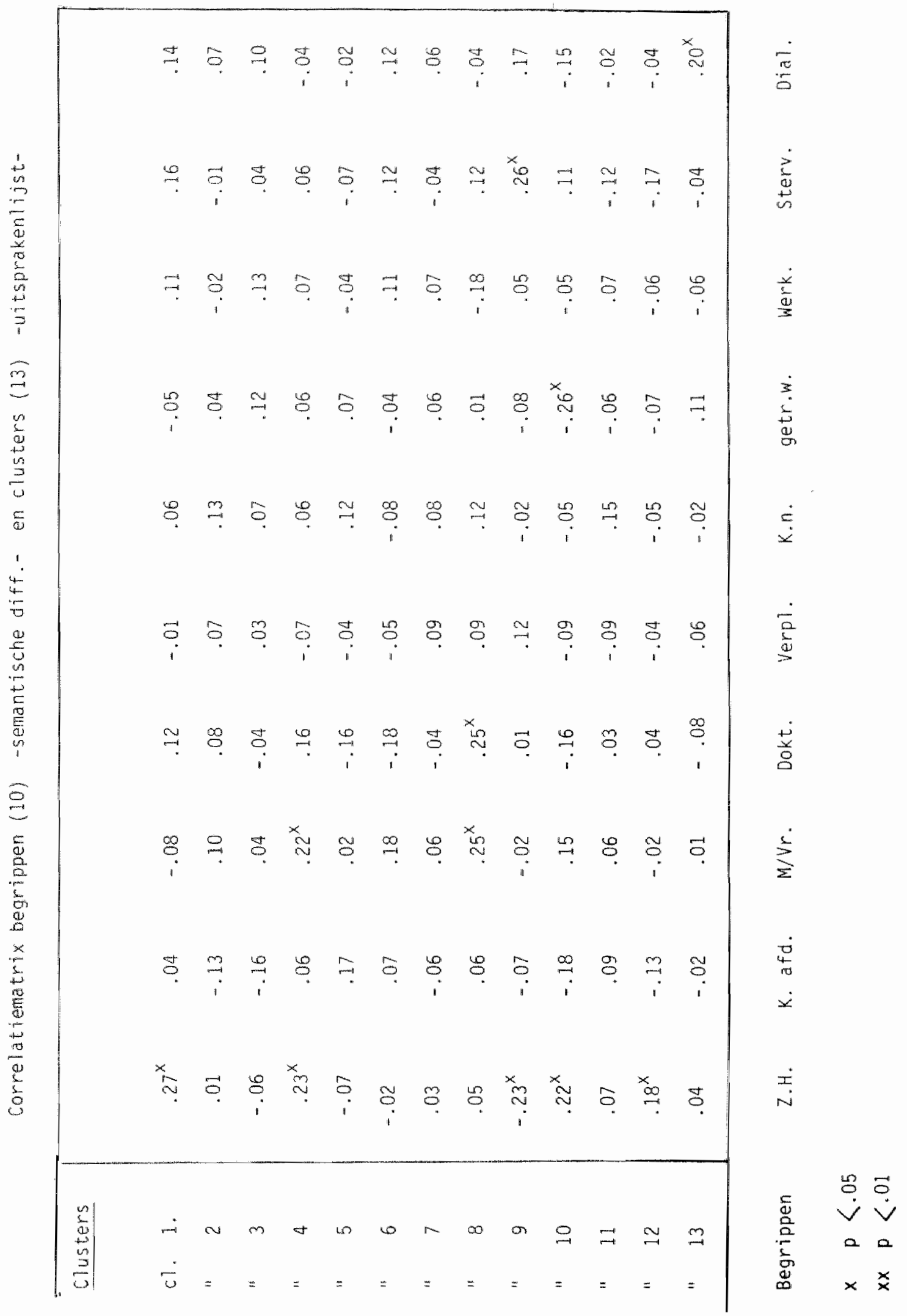


CURRICULUM VITAE

J.C. Loos, studeerde klinische psychologie aan de Vrije Universiteit te Amsterdam - hfd.vak conflictuologie - Prof. Dr. H.R. Wijngaarden -

Was van 1966 - 1971 als revalidatiepsycholoog verbonden aan het psychiatrisch ziekenhuis Veldwijk in Erme10.

Is thans als medisch psycholoog verbonden aam het ziekenhuis St.-Annadal te Mastricht.

Zijn belangstelling en specialisatie ligt met name op het terrein vân de medisch-psychologische en medisch-ethische implicaties van levensbedreigende aandoeningen. 